U N I VER S I D A D E DE S Ã O P A U L O FACULDADE DE FILOSOFIA, LETRAS E CIÊNCIAS HUMANAS DE P A R T A E N T O DE GEOGRA I A PROGRAMA DE PÓS-GRADUAÇÃO EM GEOGRAFIA HUMANA

\title{
TERRITÓRIO E FINANÇAS: \\ TÉCNICAS, NORMAS E TOPOLOGIAS BANCÁRIAS NO BRASIL
}

Fabio Betioli Contel

Orientadora: Profa. Dra. María Laura Silveira Tese de Doutoramento Novembro de 2006 
O trabalho que apresentamos pode ser considerado, num certo sentido, como o encerramento de um período iniciado em outubro de 1995. Nesta data, comecei a receber recursos do Estado brasileiro para realizar meus estudos (na forma da extinta "Bolsa de Aperfeiçoamento"), sob orientação do Professor Milton Santos.

Não há muito como explicar a felicidade destes quase seis anos de convívio, que tive o privilégio de desfrutar com o Professor até o ano de 2001. Tampouco é possível demonstrar como é grande minha gratidão por este convívio. O que é passível de ser dito é que tenho tentado - tanto na minha vida pessoal como profissional - imprimir rigor, coragem e generosidade na maior parte de meus atos. Esta tese, com todos seus defeitos, é também um resultado desta tentativa. Procurei ter sempre em mente a busca do bem público, assim como a crença na possibilidade de transformação do mundo através de nossa disciplina. Por ter me influenciado direta e decisivamente nesta busca, é que não poderia deixar de agradecer, em primeiro lugar, ao meu querido mestre, Professor Milton.

Não creio que haja técnica social mais elaborada que a família, mesmo em tempos de globalização, como forma de preparação dos indivíduos para o convívio em sociedade. É neste sentido que, também com grande emoção, agradeço meus pais, José Onildo e Eucléia, e meu irmão, Ricardo, pelo amor absolutamente incondicional que depositaram na minha formação. Jamais faltaram, e tenho certeza que jamais faltarão, seja nos momentos mais descontraídos e prosaicos de minha vida, seja nas fases mais críticas e emocionalmente custosas. Se há um pilar que me permitiu concluir este trabalho, este pilar é minha querida família.

Aqui aproveito também para agradecer meus avós maternos, Antonio Primo e Caire Costa Primo, e meus avós paternos, Geraldo Contel Betioli e Maria Thereza Betioli (in memorian]. Junto de meus tios e tias, primas e primos, constituíram igualmente 
sólido padrão de conduta e convívio, do qual tento me valer para enfrentar os sucessivos desafios que a vida nos apresenta.

Aos meus grandes amigos de Ribeirão Preto expresso no mesmo calibre meu reconhecimento de carinho e enorme amizade. Felizmente esta lista de pessoas é extensa, e evito citar algum nome específico para não cometer nenhuma indelicadeza. Saibam que minha fidelidade a vocês continua canina.

Gostaria de agradecer aos "igualmente grandes amigos" de São Paulo, cujo convívio a partir de 1990 me ajudou a entender melhor - e aproveitar intensivamente - as possibilidades que a vida na metrópole nos traz. As prazeirosas aventuras e a solidariedade compartilhada no período de nossa graduação, no Departamento de Geografia da Universidade de São Paulo, também fincaram raízes em minha personalidade.

É com imenso prazer que deixo ainda um sincero e caloroso abraço a todos os amigos, amigas e colegas de trabalho do Laboratório de Planejamento (LABOPLAN), também no Departamento de Geografia. Este convívio cotidiano auspicioso é certamente um dos eixos pelo qual meu amor pela pesquisa e docência em geografia foi construído. As amizades recentes, construídas na cidade de Jena, evocam os mesmos sentimentos.

Ainda no âmbito do LABOPLAN, gostaria de expressar meu sentimento de grande amizade pelos Professores Armen Mamigonian e Maria Adélia de Souza. À professora Mónica Arroyo, cujo trabalho firme e engajado nos inspira e influencia, gostaria de deixar um sincero e querido reconhecimento. A América Latina nos é muito mais próxima, no coração e na mente, em função de seu trabalho. À Professora Rosa Ester Rossini, desejo registrar ainda uma verdadeira dívida de gratidão. Foi sua inalcançável generosidade quem me conduziu a entrar no doutorado, e sua presença edificante durante toda a pós-graduação nos ajudou sobremaneira. 
Aos queridos funcionários do Departamento de Geografia, que desde o período do Bacharelado dispensam um tratamento eficiente, descontraído e de muita amizade a todo o colegiado de alunos.

Não poderia deixar ainda de agradecer ao Professor Benno Werlen, que gentil e afetuosamente nos recebeu por sete meses no Departamento de Geografia Social da Universidade de Jena (Alemanha). Suas contribuições seminais para a construção do conhecimento geográfico contemporâneo foram (e são) também um estímulo ininterrupto. Fica expresso igualmente o meu carinhoso obrigado aos seus assistentes Dr. Roland Lippuner, Dra. Antje Schlotmann, assim como para meu grande amigo Karsten Gäbler. Faz-se mister ainda tornar público meu agradecimento ao DAAD (Deutscher Akademischer Austauschdienst) pela concessão da bolsa que permitiu esse importante período de trabalho com o Professor Benno.

No que diz respeito ao desenvolvimento da pesquisa propriamente dito, vale ressaltar que, além da revisão bibliográfica e da compilação de dados estatísticos (principalmente do Banco Central, da FEBRABAN e da Nossa Caixa do Estado de São Paulo), o recurso a algumas entrevistas semi-estruturadas foi de significado fundamental para a construção do argumento da tese.

É neste sentido que gostaríamos de agradecer o Professor Francisco Lopreato, da Faculdade de Economia da Unicamp (SP), que dispôs de uma tarde inteira de seu trabalho em fevereiro de 2005, para nos esclarecer acerca das relações das finanças estaduais com o federalismo brasileiro. Também a entrevista realizada com o Dr. Cibilis Viana, ex-presidente do Banco do Estado do Rio de Janeiro (BANERJ), foi bastante elucidativa para o mesmo tema, e deixamos aqui expresso nosso sincero obrigado. Devo ainda ao meu amigo e colega Pablo Ibanez a gentileza de agendar essa conversa com o Dr. Cibilis. 
As entrevistas com os engenheiros Gustavo Roxo (Banco ABN/Real) e José Nitta Sala (Brinks Transportadora de Valores) nos auxiliaram sobremaneira no entendimento das questões ligadas à circulação das finanças pelos modernos sistemas técnicos que compõem nosso espaço financeiro atual. Aproveito a oportunidade para expressar meus votos de elevada estima a ambos.

Gostaria ainda de demonstrar minha enorme gratidão a Moisés da Silva Marques, doutor em Ciência Política pela Universidade de São Paulo, e trabalhador da Nossa Caixa do Estado de São Paulo. Moisés, muito generosamente, nos concedeu duas entrevistas fundamentais, em períodos distintos da redação da tese. Seu espírito republicano permitiu igualmente que entrevistássemos Juliano Cesar Rodrigues Vale e Flavio Yukawa, também da Nossa Caixa. As valiosas informações e explicações dadas por Juliano e Flávio auxiliaram decisivamente na construção do quadro da topologia bancária nacional que apresentamos na tese.

À Professora Doutora Eucléia Primo Betioli Contel (no caso, minha mãe) também pelas revisões cuidadosas da versão final do texto.

Ao Mauro Secco, pelo trabalho preciso e paciencioso na edição do texto.

Ao Conselho Nacional de Desenvolvimento Científico e Tecnológico (CNPq) pelo suporte financeiro concedido nos quatro anos de consecução da pesquisa.

À Ribeirão Preto.

Ao povo brasileiro.

À Manolita Correia Lima, pela amizade e profissionalismo na atividade acadêmica.

À Zilda Rodrigues, também uma das principais responsáveis pela minha eleição da geografia como profissão e forma de inserção no mundo. 
À Isa, que ajudou muito na minha criação, desde os períodos mais tenros, até mesmo nos dias atuais.

À Marie-Hélène, pelo enorme carinho e respeito com que sempre me tratou. Espero continuar tendo por muito tempo o privilégio de nossas conversas tão gentis e prazeirosas.

À Ana Paula Aiello, a menina mais linda que já conheci. Sua vontade inata de buscar o bem a torna ainda mais especial.

Por último, mas obviamente não menos importante, quero tentar expressar a admiração, amizade, gratidão e o carinho que tenho pela Professora María Laura Silveira. Em função da equilibrada mistura de paciência, rigor e generosidade que ela imprimiu em todo o processo de orientação desta tese é que conseguimos chegar no resultado que se apresenta. Se houver algum mérito neste trabalho, credito ele - sem pestanejar - ao talento nato da Professora María Laura para a docência e a pesquisa em geografia.

Sobre os erros presentes, também obviamente, assumo a total responsabilidade. 


\section{RESUMO}

O presente estudo analisa as relações do território brasileiro com o fenômeno das finanças. O enredo apresentado fixou os conteúdos técnicos e normativos do território, assim como a divisão bancária do trabalho neles alicerçada, como os principais critérios para a periodização do trabalho.

Neste sentido, foi possível delimitar um primeiro período que vai de 1905 a 1964, quando ocorre a gênese do moderno sistema bancário brasileiro. Os controles dos recursos financeiros são ainda regionalizados nesta fase de nossa história, e a utilização destes recursos obedece em grande parte as vicissitudes da transformação material do espaço nacional.

No período da integração e creditização do território, que se estende de 1964 até 1994, são acrescidos novos sistemas técnicos ao espaço brasileiro, que permitem um processo de internacionalização controlada de seu sistema de ações. As finanças iniciam um processo de autonomização em relação aos demais conteúdos do território, concomitantemente à inserção das técnicas da informação na dinâmica da formação socioespacial brasileira.

Após a instalação do Plano Real, no ano de 1994, inicia-se o atual período da verticalização do sistema bancário nacional, fundado principalmente num intenso processo de privatização e desnacionalização dos sistemas de ação financeiros. Além da criação de uma topologia bancária mais corporativa, a autonomização das finanças concentra em parcelas privilegiadas do território os depósitos, os créditos, assim como as instituições financeiras do País. Este arranjo verticalizado faz predominar solidariedades organizacionais ao invés de solidariedades orgânicas no uso atual do espaço brasileiro.

Palavras chave: Finanças, Sistema Bancário, Técnica, Normas, Topologia Bancária. 


\section{ABSTRACT}

The present work intends to analyse the relationships between the Brazilian territory and the financial phenomenon. The study was divided into three periods and the main criterions utilized to fix them were the normative contents of the national territory, its technical contents, as well as the banking division of labor that has its foundations based on those contents.

The first period was defined between 1905 to 1964, year in which the genesis of the modern Brazilian bank system had occurred. In this historical period there is a more effective regional control of the financial resources and their utilizations obey basically the material transformations of the national space.

The second period extends from 1964 to 1994 and is characterized by the integration and the creditization of the whole national territory; in this epoch new technical systems and devices are added to the Brazilian space, which grant an important internationalization process of all the systems of actions. Financial contents enter a process of great autonomy in relation to the other important contents of the national territory; this occurs simultaneously with the insertion of the informational technology on the dynamics of the Brazilian territory sociospatial formation.

The third period goes from 1994 - the year of the establishment of the "Plano Real" - to the present days, and is characterized by a promotion of the verticalization of the Brazilian banking system which was mainly based on the privatization and the denationalization of the financial systems. The bank topology turns out to be more corporative and deposits and credits are concentrated in privileged parts of the territory, as well as the financial institutions. This situation turned out to emphasize organizational solidarities instead of organic solidarities in the use of the Brazilian geographical space.

Key Words: Financial Phenomenon, Banking System, Techniques, Norms, Bank Topology. 


\section{ÍNDICE}

Agradecimentos

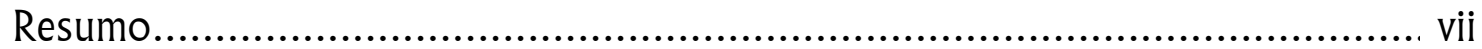

Abstract .................................................................................. vii

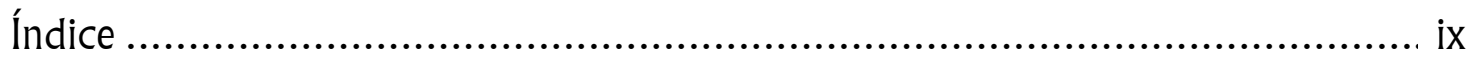

Índice de mapas, figuras, quadros e tabelas ........................................ xii

INTRODUÇÃO .......................................................................... 1

\section{PARTE 1 - TÉCNICAS, NORMAS E A GÊNESE DO MODERNO SISTEMA BANCÁRIO BRASILEIRO (1905-1964)}

Capitulo 1. Do Meio Pré-técnico ao Surgimento das Primeiras Redes Bancárias .. 15

1.1. O meio pré-técnico e o surgimento da intermediação financeira no

Brasil.

1.2. Os conteúdos normativos do território e a formação das primeiras

redes bancárias regionais

1.3. Os novos sistemas técnicos do território e o surgimento da Caixa

Econômica do Estado de São Paulo

Capítulo 2: A Renovação da Base Técnica do Território e o Moderno Sistema

Bancário ....

2.1. A construção de sistemas de engenharia e a intervenção do Estado ... 34

2.2.. A geração de energia: base para a urbanização e a industrialização substitutiva

2.3. Conteúdos industriais e o "nacional-desenvolvimentismo": a ação estatal

Capítulo 3. As Necessidades de Financiamento do Meio Técnico-Científico e

a Gênese do Sistema Financeiro Brasileiro

3.1. As técnicas bancárias e a criação da SUMOC.

3.2. A nova divisão financeira do trabalho: bancos comerciais privados,

"financeiras" e bancos estrangeiros

3.3. A SUMOC e o controle da topologia bancária .............................. 54

Capítulo 4. O Uso do Território Pelos Bancos Oficiais.................................. 58

4.1. A criação dos bancos federais regionais .................................... 58

4.2. O BNDE e o financiamento dos circuitos produtivos estratégicos ...... 64

4.3. Os bancos públicos estaduais e a ação do Banespa e da Caixa

Econômica do Estado de São Paulo ............................................. 68

CONCLUSÕES DA PARTE 1 ....................................................... 78 


\section{PARTE 2 - A CREDITIZAÇÃO E A INTEGRAÇÃO DO TERRITÓRIO NACIONAL (1964-1994)}

Capítulo 5. Urbanização, Integração e Creditização do território ....................... 84

5.1. A urbanização do território e as novas necessidades de consumo....... 85

5.2. A creditização do espaço agrícola .................................................. 88

5.3. A construção dos grandes sistemas de engenharia e a integração

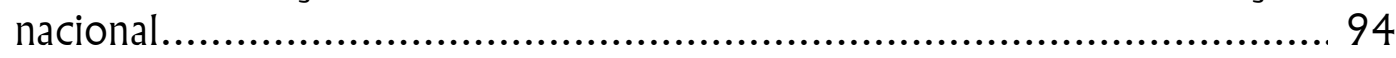

5.4. Os novos conteúdos industriais do território: a indústria pesada ....... 101 5.5. A expansão do meio técnico-científico-informacional: integração imaterial do território....................................................................... 103

Capítulo 6. A Formação do Moderno Sistema Financeiro e a Reforma Bancária

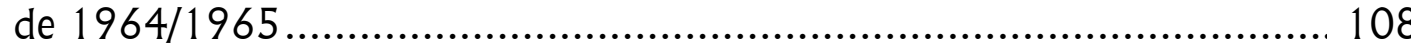

6.1. Novos sistemas técnicos bancários no país: a passagem do fazer mecânico para o fazer automático......................................................... 108 6.2. Os novos conteúdos normativos do território: a reforma bancária

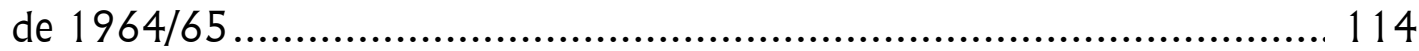
6.3. O Sistema Financeiro Nacional no período técnico-científico-

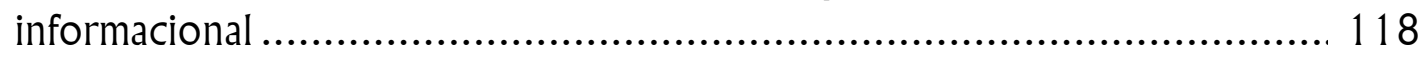
6.4.. Os títulos públicos e o aumento da participação do Estado na renovação da base material da nação................................................... 122

Capítulo 7. O Uso do Território Pelos Bancos Oficiais e Privados .................... 127

7.1. O papel do BNDE: reforço dos circuitos industriais........................ 129

7.2. A ação do Banespa: uma relação mais orgânica com o território.......... 132 7.3. A Caixa Econômica do Estado de São Paulo e a racionalização da topologia bancária

7.4. As mudanças no âmbito da Constituição de 1988: novas normas bancárias e o ambiente inflacionário ..................................................... 139

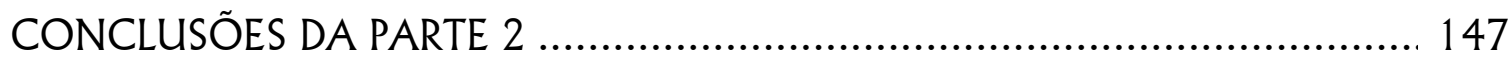

\section{PARTE 3 - A VERTICALIZAÇÃO DO SISTEMA BANCÁRIO NACIONAL: PRIVATIZAÇÕES E HIPERCAPILARIDADE DO CRÉDITO (1994-2006)}

Introdução 153

Capítulo 8. Tecnoesfera e Psicosfera: Objetos Informacionais e Ideologia da Privatização.

8.1. Os novos conteúdos informacionais: bases para uma geografia corporativa

8.2. A capilarização de novos sistemas técnicos e o uso agrícola do território

8.3. O consumo e a nova geografia urbana brasileira....

8.4. A nova psicosfera: a ideologia das privatizações e da liberalização normativa

Capítulo 9. A Construção da Racionalidade Globalizada no Território: Plano Real, PROES e PROER. 
9.1. A ação do Estado para a privatização do setor financeiro público: o PROES

9.2. A concentração induzida no sistema bancário privado: o PROER........ 189

9.3. A face organizacional da aceleração dos fluxos financeiros: alguns aspectos nacionais e internacionais

9.3.1. A rede de mensageria Society for Worldwide Interbank

Financial Telecommunication (SWIFT)........................................... 194

9.3.2. A modernização organizacional do sistema financeiro: o

Sistema de Pagamentos Brasileiro e a Rede do Sistema Financeiro

Nacional....

Capítulo 10. A Evolução Recente da Topologia Bancária e da "Geografia do

Crédito".

10.1. A nova geografia dos passivos e dos ativos regionais

10.2. A nova topologia bancária: das agências à hipercapilaridade das finanças

10.3. A evolução recente da topologia bancária "tradicional": a rede de agências.

10.4 A evolução recente da topologia bancária: os Postos de Atendimento Bancário ( $\left.\mathrm{PAB}^{\prime} \mathrm{s}\right)$

10.5. A forma contemporânea da topologia bancária: os

Correspondentes Bancários

10.5.1. Os correspondentes bancários da Caixa Econômica

Federal: os "nervos do governo"

10.5.2. A União entre o Bradesco e a rede dos Correios: o Banco Postal

Capítulo 11. Os Novos Canais Eletrônicos e a Hipercapilaridade das Finanças... 252

11.1. Os caixas eletrônicos ou ATM's .............................................. 255

11.2. Banco por internet ("Internet Banking") ...................................... 262

11.3. Centrais de atendimento telefônico ("Call-Centers") ...................... 265

11.4. Demais tipos de canais eletrônicos............................................. 266

Capítulo 12. Aspectos Locais da Evolução Recente do Fenômeno do Crédito ... 270

12.1. Novos produtos financeiros e o crédito para pessoas físicas............ 272

12.2. A hipercapilaridade e os novos objetos técnicos: o uso dos

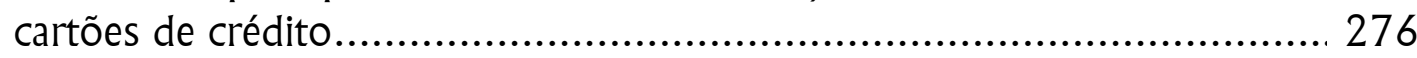

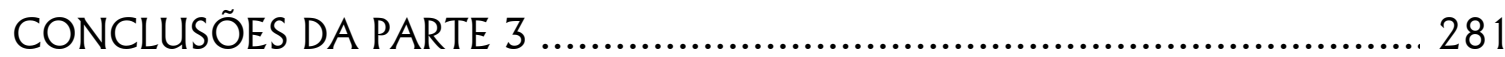

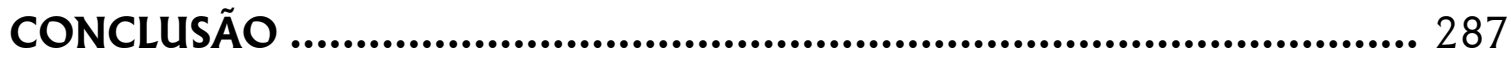

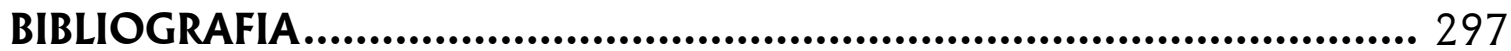




\section{ÍNDICE DE MAPAS, QUADROS, FIGURAS E TABELAS}

Mapa 1 Distribuição das Agências Bancárias da Caixa Econômica do Estado de São Paulo (1918)

Mapa 2 Distribuição das Agências Bancárias da Caixa Econômica do Estado de São

Paulo [1930]

Mapa 3 Distribuição das Agências Bancárias da Caixa Econômica do Estado de São

Paulo (1945) 74

Mapa 4 Distribuição das Agências Bancárias da Caixa Econômica do Estado de São Paulo [1964) 75

Mapa 5 Distribuição das Agências e dos Postos de Atendimento Bancários da Caixa Econômica do Estado de São Paulo (1988) 140

Mapa 6 Distribuição das Agências e dos Postos de Atendimento Bancários da Caixa Econômica do Estado no Município de São Paulo (1988)

Mapa 7 Distribuição das Agências e dos Postos de Atendimento Bancários da

Nossa Caixa Nosso Banco no Estado de São Paulo [1994]

Mapa 8 Distribuição das Agências e dos Postos de Atendimento Bancários da

Nossa Caixa Nosso Banco no Município de São Paulo (1994).

Mapa 9 Distribuição das Agências, PAB's e Correspondentes Bancários da Nossa

Caixa no Estado de São Paulo (2006)

Mapa 10 Distribuição das Agências, PAB's e Correspondentes Bancários da Nossa

Caixa no Município de São Paulo (2006)

Mapa 11 Distribuição dos Terminais do Banco 24 Horas no Município de São Paulo (2006)

Mapa 12 Distribuição dos Terminais do Banco 24 Horas na Região Norte (2006)..... 260

Quadro 1 Brasil: Interiorização das Agências do Banco do Brasil (1905-1919)

Quadro 2 Brasil: Conexões por Visibilidade e por Tropodifusão no Território (1972) .. 106

Quadro 3 Estrutura do Sistema Financeiro Brasileiro a partir da Reforma de 1964/65 ... 119

Quadro 4 Brasil: Instituições financeiras estaduais extintas/em liquidação ordinária (2002) ... 179

Quadro 5 Brasil: Bancos Estaduais Privatizados Diretamente no Âmbito do PROES (1996-2001) 
Quadro 6 Brasil: Bancos Estaduais Privatizados Após Federalização no Âmbito do PROES [1996-2006)

Quadro 7 Brasil: Bancos Vendidos com Recursos do PROER, por Tipo de Operação (1995-2000).

Quadro 8 Brasil: Quantidade de Famílias Beneficiadas pelos Programas Sociais do Governo Federal (2006)

Quadro 9 Comparação dos Custos de Transação Bancária, por Carta, Telefone e Internet ......

Quadro 10 Brasil: Evolução dos Custos das Operações por Sistema Técnico Utilizado (2000)

Figura 1 Brasil: Rede do Sistema Financeiro Nacional (2006)

Tabela 1 Brasil: Evolução do Sistema de Movimento Ferroviário (1854-1945)

Tabela 2 São Paulo: Evolução do Sistema Bancário (valores em mil réis) (1919-1928)

Tabela 3 Brasil: Distribuição dos Ativos e dos Passivos Regionais (em \%) (19451965) 50

Tabela 4 Brasil: Distribuição dos Bancos Privados no Território Nacional (1963) 51

Tabela 5 Brasil: Evolução do Número de Agências e Matrizes de bancos (19461965) 54

Tabela 6 Brasil: Evolução das Operações Aprovadas pelo BNDE, Segundo as Atividades Econômicas Beneficiadas (em Cr\$ milhões de 1981) (1953-1965) 67

Tabela 7 Brasil: Evolução da Área Irrigada no Território Brasileiro, por Grandes Regiões (em ha) (1960-1985)

Tabela 8 Brasil: Evolução da Frota de Tratores e do Índice de Tratorização do Território Brasileiro (1960-1980)

Tabela 9 Brasil: Evolução do Crédito Rural Concedido e Outros Indicadores (em milhões de cruzeiros de 1977) (1969-1890)

Tabela 10 Brasil: Evolução da Rede Rodoviária Pavimentada Segundo as Grandes Regiões em km [1964-1991]

Tabela 11 Brasil: Empréstimos ao Setor Privado Realizado pelos Agentes do Sistema Financeiro (em \% dos totais) (1968-1975)........................................... 124

Tabela 12 Brasil: Principais Ativos Financeiros Nacionais em \% (1964-1984) 
Tabela 13 Brasil: Evolução do No. de Bancos e de Agências Bancárias (1964-1980)..... 128

Tabela 14 Brasil: Evolução das Operações Aprovadas Pelo Sistema BNDE Segundo o Setor Beneficiado (em Cr\$ milhões de 1981) (1972-1980)

Tabela 15 Brasil: Distribuição Regional dos Depósitos em Caixas Econômicas (em \%) [1964-1979]

Tabela 16 Brasil: Evolução do Número de Bancos no Território Brasileiro (1986-1995) .... 144

Tabela 17 Brasil: Criação de Infra-estruturas em Áreas Agrícolas pelo Governo Federal (1995-1998)

Tabela 18 Estado de São Paulo: Ano de Inauguração dos Hipermercados Extra. 164

Tabela 19 Brasil: Evolução dos Recursos Gastos com o PROES (Títulos emitidos em R\$ milhões) (1996-2004).

Tabela 19 Brasil: Evolução dos Recursos Gastos com o PROES (Títulos emitidos em R\$ milhões] (1996-2004) continuação.

Tabela 20 Evolução do Número de Mensagens, Clientes e Países Abrangidos pela SWIFT (1973-2005)

Tabela 21 Brasil: Sistema de Compensação e de Liquidações - Operações Processadas (2005)

Tabela 22 Brasil: Evolução da Participação das Instituições Bancárias nas Operações de Crédito Concedidas no Território (1996-2004)

Tabela 23 Brasil: Evolução da Participação das Instituições Bancárias nas Operações de Depósito Realizadas no Território (1996-2004)

Tabela 24 Brasil: Evolução dos Ativos Regionais (Depósitos Bancários) no Território (em \%) (1997-2004)

Tabela 25 Brasil: Evolução dos Passivos Regionais (Créditos Bancários) no Território (em \%) (1997-2004)

Tabela 26 Brasil: Evolução da Topologia Bancária (Agências) nas Regiões Brasileiras, Exceto a Região Concentrada (1994-2004)

Tabela 27 Brasil: Evolução da Topologia Bancária (Agências) na Região Concentrada do Território Brasileiro (1994-2004)

Tabela 28 Brasil: Evolução da Topologia Bancária (Postos de Atendimento Bancário) na Região Concentrada (1994-2004) 230

Tabela 29 Brasil: Evolução da Cobertura Bancária (Postos de Atendimento Bancário) nas Regiões Brasileiras Exceto a Região Concentrada (1994-2004) 
Tabela 30 Brasil: Evolução da Qualidade dos Fixos Geográficos Financeiros no Território (2000-2005) ................................................................. 237

Tabela 31 Brasil: Distribuição dos Correspondentes Bancários no Território (2002) ..... 244

Tabela 32 Brasil: Evolução dos Correspondentes Bancários no Território (por Banco

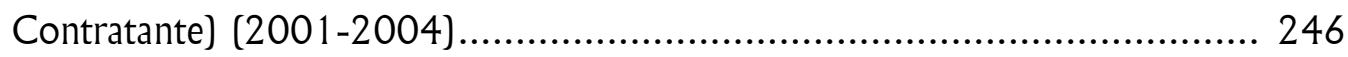

Tabela 33 Brasil: Distribuição dos Caixas Eletrônicos da Rede "Bancos 24 Horas"

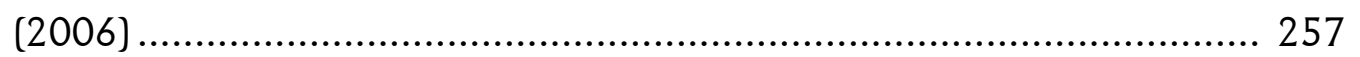

Tabela 34 Brasil: Evolução dos Caixas Eletrônicos Segundo sua Localização Comercial

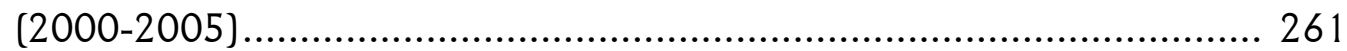

Tabela 35 Brasil: Evolução Recente do Número de Contas-corrente e Poupança

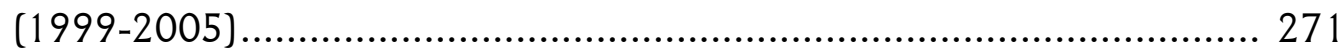

Tabela 36 Brasil: Evolução Recente do Volume de Créditos Livres (em R\$ milhões) (2003-2005).

Tabela 37 Brasil: Evolução dos Créditos com Recursos Livres para Pessoas Físicas (em R\$ milhões) (2004-2006)

Tabela 38 Brasil: Evolução do Número de Cartões de Crédito e de Transações Realizadas (1991-2005) 


\section{INTRODUÇÃO}

O fenômeno das finanças, em seus aspectos mais gerais, desde tempos mais remotos pode ser considerado como um elemento constitutivo do espaço geográfico. O surgimento das primeiras moedas é um atributo eminentemente urbano, lembra-nos Fernand Braudel $(1979,2005)$. As moedas, além de permitirem uma aceleração das trocas comerciais, tornaram possível um entesouramento maior das riquezas; assim, surgem também as primeiras casas bancárias no continente europeu. Das moedas "fiduciárias" (as notas de banco) se desenvolve ainda o fenômeno do crédito, que não é nada mais que "a troca de duas prestações diferentes no tempo: eu lhe presto serviço, você me reembolsa depois" (BRAUDEL, op. cit::431).

Henry Pirenne (1933, 1966:144) é ainda mais enfático, quando assevera que "sem o crédito e o comércio de dinheiro, a vida econômica da Idade Média tornarse-ia incompreensível". Para o autor, foi "nas grandes cidades italianas onde aparecem os primeiros fundamentos do crédito e das instituições bancárias do futuro". Pode-se dizer, portanto, que cada época mostra uma combinação específica de técnicas financeiras e de organização do espaço geográfico.

O próprio surgimento dos Estados territoriais modernos é, em grande medida, um resultado de uma combinação entre o controle das finanças e o espaço. Como nota Jean Gottmann (1944: 121 e ss.) para o caso francês, foi justamente a partir da habilidade de Sebastien Le Preste Vauban em mapear o território francês, e instituir ali um eficiente sistema de coleta de impostos, que se formou um exército regular nacional, que conservou as fronteiras do País como hoje as conhecemos.

O fenômeno moderno da industrialização - processo essencial para a organização dos territórios - também é em grande parte tributário das finanças. É Alexander Gerschenkron (1978:156 e ss.) que nos mostra que a ação dos bancos na Europa do século XIX permitiu que fossem realizados empréstimos em prazos mais longos 
no continente, que por sua vez impulsionaram uma outra revolução industrial naquele período. Os bancos, neste sentido, transformaram a "velha riqueza" numa “nova riqueza” na Europa (GERSCHENKRON, 1978:156).

Essa importância das finanças (isto é, da moeda, do crédito, do endividamento, dos juros etc.) e de seus atores (os bancos, as "financeiras", e demais credores e emprestadores) parece ter atualmente, chegado num novo patamar. Poucas são as atividades ditas "econômicas" que se fazem sem o acesso a algum tipo de instrumento financeiro. Desde os empréstimos internacionais, realizados entre grandes empresas e Estados, até uma operação de crédito consignado, demandado por um aposentado numa pequena cidade do interior do território brasileiro, a finança parece ter ganhado uma influência inaudita no atual momento de nossa civilização.

Outro indicativo dessa importância é dado pelo próprio acompanhamento diário da chamada mídia (seja ela televisiva, radiofônica, ou impressa). Os noticiários destacam parcelas cada vez mais expressivas de sua programação para a discussão de temas como as "bolsas de valores" no mundo, as "taxas de juros" dos Países, os "ritmos de crescimento dos índices econômicos" etc. O que teria ocorrido recentemente? Porque os fenômenos financeiros ganharam essa importância no mundo atual? Quais os processos que levaram a essa primazia das finanças na organização da sociedade contemporânea?

Estas perguntas, ao que nos parece, podem ser parcial e satisfatoriamente respondidas através de uma análise geográfica, ou espacial. Este é na verdade, o grande objetivo desta tese: analisar a evolução recente do fenômeno das finanças em sua relação com o espaço geográfico. Ou dito em termos mais precisos: verificar quais foram as condicionalidades recíprocas entre o funcionamento do território brasileiro e de seu sistema bancário (e financeiro), no período recente. 
Definido o objetivo do presente trabalho, resta saber: quais os instrumentos conceituais que podem nos ajudar na pesquisa? Que partidos de método podem ser mais operacionalizáveis para a execução do trabalho?

Todas as áreas do conhecimento possuem pressupostos conceituais e categoriais, assim como uma história e uma tradição discursiva que conferem a cada uma um lugar no concerto das ciências. Pode-se dizer que os ramos do saber se constituem como "ontologias regionais" (THOM, 1990), com suas respectivas "epistemologias regionais" (BUNGE, 1980). Fazer passar as categorias abstratas do conhecimento geográfico para conceitos historicamente operacionalizados é tarefa precípua de qualquer pesquisa em geografia, já nos alertava o professor Armando Corrêa da Silva (1986). Quais seriam, destarte, as principais categorias que pretendem ser trabalhadas nesta tese?

A primeira e mais importante categoria é a de espaço geográfico. Não se trata nem do espaço geométrico estudado por matemáticos e físicos, nem do espaço econômico dos planejadores e economistas, assim como não é o caso de partir do espaço social dos sociólogos e antropólogos. O espaço geográfico, categoria basilar, é esse híbrido de que nos fala Milton Santos (1996), essa "formaconteúdo" (1978, 1990; 1979; 1996), que tanto engloba a materialidade do mundo quanto as organizaçôes, açôes e sistemas de vida que necessitam desta materialidade para se reproduzir. Neste sentido, podemos falar que o espaço geográfico é sempre uma forma, uma extensão, mas que possui conteúdos técnicos, normativos, econômicos, sociais etc. Como definir estes "conteúdos do espaço"?

Aqui entram as categorias que nos ajudam a compreender a natureza íntima do espaço geográfico. Possivelmente aquela que vem se constituindo há tempos como uma das mais profícuas para a análise geográfica é a técnica. A técnica, a bem da verdade, "é a fatalidade de nossa época, onde fatalidade significa o inevitável de um processo inexorável e incontornável", nos ensina Martin Heidegger (1954, 
2002:28). Neste sentido, interfere não só no espaço geográfico, mas em praticamente todas as "instâncias sociais" (SANTOS, 1978, 1990) como a cultura, a economia, a sociedade etc.

No seu aspecto mais amplo, assevera Ortega y Gasset $(1939,1991: 12)$, a técnica "é a reforma que o homem impõe à natureza em vista da satisfação de suas necessidades". Ela é, por definição, o ente que media a relação dos seres humanos com o meio geográfico: "a técnica", ainda segundo o filósofo espanhol, "é o contrário da adaptação do sujeito ao meio, visto que é a adaptação do meio ao sujeito". “(...) Essa reação contra aquilo que o cerca, esse não resignar e contentar-se com o que 0 mundo é, constitui-se no específico do homem"(ORTEGA Y GASSET, 1939, 1991:13).

Também o geógrafo Milton Santos vem chamando a atenção - desde ao menos o final da década de 1950 - para a importância do fenômeno técnico nos estudos geográficos. Na introdução de um de seus livros sobre a geografia da Bahia, publicado em companhia de seu mestre Jean Tricart, Milton Santos (1958:7) propunha que a geografia poderia ser considerada como uma "filosofia das técnicas". O que se quer exprimir com esta proposição? Por que a geografia pode ser entendida como uma "filosofia das técnicas"? "A técnica, ela própria, é um meio", lembra-nos ainda Milton Santos (1996:32). Neste sentido é possível pensar numa "filosofia", isto é, num corpo sistematizado de conceitos que dêem conta de entender as mediações estabelecidas pela técnica, o meio e os atores que dele se utilizam.

A definição de técnica aqui empregada se inspira também na noção desenvolvida por Marcel Mauss (1947), para quem as técnicas são sempre técnicas sociais, sejam elas técnicas corporais, de consumo, de produção, de transporte etc. Estas técnicas, já que mediam também as relações dos atores entre si, são hoje importante elemento de poder, e a banalização daquelas mais modernas ou contemporâneas (como as "técnicas da informação"), na maior parte das vezes tem 
servido para aumentar as desigualdades entre as pessoas e os lugares, e não o contrário.

As técnicas, assim como os objetos técnicos que povoam o espaço geográfico, não podem ser funcionalizadas ou colocadas em movimento sem as ações humanas. A ação, portanto, é outra categoria que nos permite estabelecer um quadro fidedigno do mundo contemporâneo, a partir de uma visão geográfica. Há tempos a geografia vem se preocupando em incorporar o tema da ação em sua tradição discursiva. Foi o caso pioneiro, por exemplo, de Jean Brunhes (1920, 1962:441), que em seu Geografia Humana mostrava que "o homem nunca é completamente passivo" e “(...) enquanto vive, ele age, reage; bebe, come, se estende em um ponto do globo para dormir, atos estes em que é fácil reconhecer o gesto de sua própria participação nos fatos geográficos".

Esse esforço para incorporar a ação na epistemologia da geografia foi também o que levou Pierre George (1966:148) a afirmar que a região poderia ser definida "enquanto espaço animado por ações e relações promovidas pelo homem", além de ser "um espaço dominado por um centro de gestão e de comando, que é a cidade". Assim procedeu também Claude Raffestin (1980, 1993), que dividiu as ações (e os atores) em seu esquema teórico entre "sintagmáticos" e "paradigmáticos". Os primeiros englobariam aqueles atores que possuem interesses organizados, e que executam "programas" definidos (como as empresas, o Estado, a Igreja, os partidos políticos etc.). Os de segundo tipo "não estão integrados num processo programado" (RAFFESTIN, 1980, 1993:41), e podem ser considerados como a "população em geral"; se constituem, destarte, como "trunfos" ou "massa de manobra" para os atores sintagmáticos.

Recentemente, um dos passos mais importantes para incorporar a ação em definitivo no discurso teórico da geografia humana foi realizado pelo geógrafo suíço Benno Werlen (1988, 1993; 1999; 2000; 2003). A bem da verdade, o autor "inverte" a relação espaço-ação para um esquema teórico ação-espaço; para 
ele, a geografia teria como objeto de estudo a própria ação, e não o espaço. Os dados da materialidade (do "mundo externo" aos indivíduos) devem ser considerados junto do "estoque de conhecimento" (isto é, da "subjetividade") e do "mundo sociocultural" (da "co-presença" dos indivíduos), como os elementos delineadores das ações. Definidas as ações por estes três elementos, é possível estabelecer "regionalizações cotidianas" do espaço geográfico (WERLEN, 1988, 1992).

No início da década de 1990 o geógrafo Milton Santos $(1992,1994)$ nos apresenta uma concepção de espaço que incorpora em seus aspectos constitutivos o fenômeno da ação humana. Para o autor, dado o estágio atual do desenvolvimento das técnicas, tanto as ações quanto os objetos técnicos são dotados de extrema intencionalidade, que nos permite analisá-los de forma indissociada. Para Santos (1994:90), "os sistemas de objetos não funcionam e não têm realidade filosófica, isto é, não nos permitem conhecimentos, se os vemos separados dos sistemas de ações. Os sistemas de ações também não se dão sem os sistemas de objetos".

As ações, portanto, mostram-se essenciais para o entendimento de como são funcionalizadas as redes, os sistemas de engenharia, os objetos e todos os demais dados da materialidade das regiões que são parte da estratégia de atores (individuais ou coletivos). Empresas, Estados, populações e indivíduos são passíveis de serem analisados através de sua ação, mas através de sua ação "objetual", não-desvinculada dos instrumentos técnicos (fixos ou portáteis, materiais ou organizacionais) de que fazem uso para a consecução de seus objetivos.

Uma terceira e não menos importante categoria analítica da geografia seria a de evento. Ainda para Milton Santos, "evento e ação são sinônimos"(1996:117), já que ambos têm como destino último os objetos ou extensóes que compõem o espaço geográfico. "O evento", assevera também Fernand Braudel [1969, 
1992:45), "é explosivo", "novidade sonante", e pode se manifestar numa notícia, numa decisão empresarial, numa política pública, numa idéia, na promulgação de uma lei etc. Alguns eventos, porém, acabam por se geografizar (em maiores ou menores escalas), e deixam de fazer parte do que Braudel também denominou de "tempo curto" para se tornarem "longa duração". A própria "duração", neste sentido, pode ser entendida como "a persistência de um evento" ("persistance d'un événement"), nos ensina Antoine Bailly (1995:174).

Essa instalação dos eventos no espaço, por sua vez, depende dos conteúdos políticos, sociais, culturais e econômicos de cada lugar; quando há aderência entre ambos (espaço e evento), ocorre a "precipitação eficaz" (FOCILLON, 1943, 1988:99) do evento.

Outra categoria central que nos permite estabelecer um quadro teórico-empírico da relação entre o território brasileiro e as finanças é a norma. Não no seu sentido geral de uma "fórmula abstrata daquilo que deve ser"(LALANDE, 1926, 1996:736), mas em uma acepção mais específica como "regra", "lei", ou simplesmente como "norma jurídica". Nos quadros de uma formação socioespacial, elas delimitam a dinâmica de cada ator na divisão social do trabalho, assim como procuram regular a distribuição dos elementos do espaço geográfico (empresas, infra-estruturas, incentivos fiscais etc.). Uma norma jurídica pode autorizar (ou não) que um evento histórico se geografize na parcela do espaço sobre a qual ela tem poder de regulação.

A novidade do período atual se dá por conta de um aumento do poder normativo de corporaçóes transnacionais e dos organismos multilaterais globais (como a Organização Mundial do Comércio, o Fundo Monetário Internacional, e mesmo a Organização das Nações Unidas). Para garantir maior eficácia na busca das empresas globais por novos mercados e nichos de investimento, decisões normativas tomadas neste âmbito global são impostas com freqüência aos Estados nacionais, obrigando-os - com a conivência de parte das elites locais - a 
readequarem os conteúdos normativos de seus territórios em função de lógicas exógenas.

As normas acabam por consolidar uma unicidade do planeta (SANTOS, 1994) que vem se dando com força em seus aspectos técnicos ao menos desde as décadas de 1950 e 1960. Neste mundo bastante integrado em termos materiais, vem sendo imposto um novo conjunto de regulações que permitem a livre movimentação de capitais financeiros, fluxos de mercadorias, assim como de "investimentos externos diretos" (IED's), principalmente para a melhor performance dos atores globais. As normas, neste sentido, são também cada vez mais "produtoras de unicidades" (SILVEIRA, 2000a; 2000b), já que substituem gradativamente uma regulação nacional (dada, no limite, pelas Constituições dos Países) por uma regulação global. "O conflito entre essas normas deve, hoje, ser um dado fundamental da análise geográfica", lembra-nos Milton Santos (1994:19).

Mais um pressuposto de método do que uma categoria filosófica, a periodização é uma ferramenta teórica também essencial para os estudos geográficos. Só é viável valorizar adequadamente os fenômenos sociais a partir de seu contexto histórico; ou como alerta Paul Baran (1968:16), não é possível estabelecer juízos válidos “sem limitações de tempo e espaço". Assim a periodização se constitui numa maneira de se incorporar a dimensão temporal na análise do espaço, como assevera Milton Santos (1972; 1979b; 1985, 1988). Ainda para Santos, “cada período pode ser considerado como um segmento homogêneo de tempo histórico, em que as variáveis se mantêm em equilíbrio no interior de uma mesma combinação"[SANTOS, 1979b:26). Identificadas a (ou "as") variável-chave de cada período, é possível hierarquizar tanto os dados empíricos que se têm para serem trabalhados (estatísticas, documentos) quanto a posição que cada ator concreto (os tipos de empresas, as regiões) vai ocupar nesta hierarquia de variáveis.

Mas não só por isso a periodização é importante. Ela nos permite ainda identificar com mais facilidade a dialética do "novo" e do "velho", das "mudanças" e das 
"permanências" em cada parcela do espaço geográfico. Uma novidade histórica introduzida num contexto espacial, caso tenha força suficiente para interferir no equilíbrio da combinação espaço-temporal vigente, pode mesmo gerar uma ruptura desta combinação. Esta ruptura, por sua vez, instala um novo período histórico. Esse foi o caso da "revolução técnico-científica" (RICHTA, 1972), ocorrida em meados do século passado, como parece ter sido o da "revolução informacional"(LOJKINE, 1992), iniciada com vigor nos anos 1970. Ambas introduziram novidades com tal força no sistema temporal existente, que de certa forma romperam com esse sistema, reorganizando as variáveis-chave do período numa nova combinação.

O tema da periodização, por sua vez, nos remete ao último - mas não menos importante - par de categorias que serviram de alicerce para nossa tentativa de analisar as relações das finanças com o espaço geográfico: a totalidade e a totalização histórica. O que significam estas duas noções? Como proceder a um estudo geográfico a partir de uma totalidade?

Como nos propõe Henri Lefebvre (1955:73), a totalidade seria a mais abrangente e importante ferramenta teórica para as ciências humanas. Para o autor, "a 'totalidade' envolve (enveloppe) a natureza e seu futuro, o homem e sua história, a consciência e suas consciências, suas idéias e ideologias". É a partir dela que se torna possível analisar cada fato particular da realidade histórica, tornando-o parte constituinte de um todo que está sempre a se renovar. Nem se subdimensiona, nem se sobredimensiona o valor das ações e dos atores particulares; cada parcela das sociedades e dos territórios carrega em si uma parcela da totalidade, e a partir dela se desenvolve.

Também neste sentido é que Jean-Paul Sartre (1966:25) nos lembra que "os fatos nunca são aparições isoladas" e que "se eles se dão em conjunto, é sempre na unidade superior de um todo, que estão ligados entre si por relações internas e que a presença de um modifica o outro em sua natureza profunda". Daí que 
identificar sucessivas totalidades, dadas em cada período histórico - como vimos revelar-nos-ia o próprio movimento do mundo, que é uma "totalização que se totaliza sem cessar; os fatos particulares nada significam, não são nem verdadeiros nem falsos enquanto não forem referidos pela mediação de diferentes totalidades parciais à totalização em curso" (SARTRE, op. cit::30).

Mas de que tipo de totalidade estaríamos falando, no caso da geografia? Uma aproximação possível nos é dada pelo economista francês François Perroux (1967). Através de seu conceito de "espaço banal" foi possível pensar a categoria totalidade em termos mais específicos, ligados ao estudo do espaço. Para Perroux (1967:149), o espaço banal (ou "geonómico") englobaria os "pontos, linhas, superfícies", assim como "os homens e grupos de homens, as coisas e os grupos de coisas" em seu funcionamento complexo.

Essa é a proposição que em grande parte permitiu ao geógrafo Milton Santos [1996:258) propor que o espaço geográfico - sinônimo de espaço banal abrangeria "todos os capitais, todos os trabalhos, todas as técnicas e formas de organização", sendo a partir desta base que os estudos em geografia poderiam ser levados a cabo. Na presente tese, procurou-se trabalhar com os atores financeiros e bancários, mas também com os demais tipos de atores que com eles se relacionam diretamente: atores industriais, comerciais, indivíduos etc. Neste sentido é que procuramos dar destaque às redes de circulação de capitais, mas também às de transporte, de geração de energia, assim como às demais manifestações extensivas que compuseram as sucessivas totalidades territoriais do País, em cada período abordado.

Não foi por outro motivo que se procurou ainda entender o processo de totalização histórica na escala local (isto é, nos lugares), mas também nas regióes (ou estados da Federação) e na formação socioespacial brasileira, sem deixar de verificar quais as influências da "totalidade-mundo" nestas "escalas do acontecer" (SANTOS, 1996:131 e ss.). "Como os fatos sociais", lembra-nos Hildebert 
Isnard (1981:77), “os fatos espaciais não são apreendidos separadamente: somente os atingimos em suas interdependências pelas quais se define a lógica interna de sua totalidade". Faz-se necessário - para a consecução da análise geográfica - partir das especificidades locais, mas também levar em conta os processos mais gerais que incidem sobre elas, sejam estes processos provenientes das escalas regionais, nacionais ou mundiais.

Neste sentido, é possível perguntar: quais os elementos concretos que foram analisados para o entendimento da relação entre as finanças e o espaço geográfico? Como propunha o próprio Professor Milton Santos, como construir uma "teoria menor" sobre o tema em tela? Ou ainda nas palavras de Karel Kosik (1966, 1986), qual a amarração entre as variáveis históricas e as categorias do conhecimento que permitiram tentar passar de uma visão "pseudoconcreta" da realidade, para uma verdadeiramente "concreta"?

Para iniciarmos o estudo, propusemos cinco critérios para chegarmos a uma periodização adequada do tema:

a) Análise da evolução das técnicas bancárias, ou das "técnicas do dinheiro" como qualificara Fernand Braudel $(1979,2005)$

Partindo desta concepção mais ampla da técnica, foi buscada a definição de quais os principais sistemas técnicos ligados à circulação das finanças e quais as redessuporte das instituições de crédito presentes no território. Procurou-se ainda analisar quais os tipos de produtos e serviços bancários à disposição dos atores econômicos instalados no território, em cada período.

b) Análise dos atores, ou da divisão do trabalho bancário instalados em cada período

A evolução da análise realizada mostrou que em cada período houve uma importância maior da ação de bancos estrangeiros, ou de bancos nacionais na intermediação financeira brasileira. Assim como foi constantemente alterada esta 
dialética entre o "externo" e o "interno", também aquela ligada ao "Estado" e ao "mercado" interferiu no uso financeiro do território. Isto é, cada período guarda uma especificidade em relação ao predomínio de bancos oficiais ou instituições privadas, no comando do uso financeiro do território. Tentou-se ainda identificar como evoluíram os atores por suas diferentes topologias, isto é, como se comportaram, em cada período, os bancos locais, regionais (estaduais) e nacionais no território.

\section{c) Definição das sucessivas divisões territoriais do trabalho}

A cada período parecem ter surgido ainda arranjos territoriais específicos, no que diz respeito ao comando dos processos financeiros da nação. Foi possível identificar regiões mais dinâmicas que outras em termos de quantidades de depósitos e de empréstimos realizados, assim como lugares de maior densidade da rede bancária, e outros com menores densidades de recursos e equipamentos técnicos.

d) Definição das principais normas jurídicas que interferiram no uso financeiro do território

Através da análise das Leis, Decretos e Regulamentaçôes que mais tiveram influência direta na distribuição dos atores, na oferta de serviços bancários, na extensão das redes de prestação de serviços etc. foi possível também verificar como certos eventos ligados à circulação de capitais no País foram alterados em cada período.

e) A preocupação com a totalidade:

Ao longo do trabalho, tentamos também definir quais os demais conteúdos do território ("não-financeiros") que tiveram influência - direta ou indireta - na evolução do sistema bancário nacional. Assim, as distintas redes-suporte (de transporte, de telecomunicações), as outras atividades econômicas (comerciais, industriais), assim como o aumento da população/urbanização do território etc. serviram de parâmetro para a construção da possível coerência filosófica da tese. 
A operacionalização destas premissas acabou por nos fazer estruturar o trabalho em três partes, cada qual procurando formar um período, com homogeneidade e sistematicidade entre suas variáveis constituintes.

O primeiro período vai de 1905 até 1964, quando se dá a gênese do moderno sistema bancário brasileiro. Foi possível identificar, de início, quais as características do espaço geográfico que facilitaram (ou não) a instalação das atividades de intermediação financeira no território brasileiro, analisando exemplos de variações regionais destes conteúdos e de sua relação com a gênese do sistema bancário. A menor quantidade de inovações técnicas observadas, assim como a maior continuidade dos processos econômicos ocorridos neste sistema temporal permitiu que o definíssemos como uma totalidade, apesar de incorporar quase sessenta anos em sua evolução.

Assim como nas demais partes da tese, procurou-se atentar para as diferentes densidades e topologias do fenômeno financeiro no território, principalmente no que tange aos índices de concessão de crédito e de recebimento de depósitos no sistema bancário nacional.

A segunda parte da tese foi intitulada "creditização e integração do território brasileiro", que engloba os anos de 1964 a 1994. Neste período da relação entre as finanças e o espaço nacional, ocorre uma maciça expansão do meio técnicocientífico em direção ao interior do território, principalmente em função de uma série de iniciativas do Governo Federal para a integração do País.

O sistema financeiro conhece uma ruptura normativa e institucional expressiva, com a realização da chamada "Reforma Bancária" de 1964/1965. A Reforma permite a entrada de novos atores no sistema financeiro nacional, assim como torna bem mais complexa a burocracia estatal que cuida da regulação do sistema bancário nacional. 
O Plano Real, instalado no ano de 1994, inaugura a fase atual do funcionamento do sistema bancário brasileiro, em sua relação com o território. Nesse momento, tanto a finança como a informação ganham, em definitivo, uma predominância destacada na organização dos demais conteúdos do espaço geográfico brasileiro.

Esta ascensão das finanças e da informação se dá em grande parte pelas alterações nos conteúdos imateriais (novas ideologias "neoliberais" entram em cena) que dirigem boa parte do comportamento da elite política do país. Uma série de políticas públicas implementadas pelo próprio Governo Federal vai levar a um processo de privatização e desnacionalização do sistema bancário brasileiro jamais visto na sua história.

Em função também da banalização das técnicas da informação no território, a topologia bancária brasileira - historicamente baseada numa rede de agências - se altera profundamente. É neste contexto temporal que se cria uma enorme quantidade de novos fixos geográficos na rede nacional de prestação de serviços bancários. Data ainda desta fase de nossa história o surgimento de uma série de "canais eletrônicos", que potencializam o acesso dos atores econômicos aos recursos financeiros. Por fim, procurou-se entender como esse processo de verticalização do sistema bancário nacional repercutiu nas escalas locais do território, ou seja: de que forma os novos produtos financeiros passam a fazer parte da vida cotidiana das populações urbanas brasileiras?

Estes são, em linhas gerais, os grandes eixos pelos quais nos esforçamos em desenvolver o argumento da tese. Parafraseando o filósofo Lucien Goldmann (1952, 1979; 1972), pode-se dizer que o presente estudo procurou estabelecer "o máximo de consciência possível" acerca da problemática eleita. Através da operacionalização dos conceitos e categorias descritas, foi permitido criar uma série de retratos teórico-empíricos da relação das finanças com território, que apresentamos a seguir, segundo a periodização proposta. Estes procedimentos é que nos levaram, quiçá, a chegar num quadro explicativo verossímil sobre o tema. 


\section{PARTE 1 - TÉCNICAS, NORMAS E A GÊNESE DO MODERNO SISTEMA BANCÁRIO BRASILEIRO (1905-1964)}




\subsection{O meio pré-técnico e o surgimento da intermediação financeira no Brasil}

Ao final do século XIX havia no território brasileiro um sistema bancário pouco desenvolvido. Era raro o uso de cheques, e a "escassez de numerário" não era fato incomum (COSTA NETO, 2004:15). A cidade do Rio de Janeiro concentrava cerca de $80 \%$ de todos os depósitos bancários realizados. Eram significativas as dificuldades para que aqui fossem criados bancos ou casas bancárias, que viessem a suprir de créditos as atividades econômicas mais dinâmicas do território.

Uma primeira dificuldade, datada já do período do Império (mas com repercussões também nos primeiros anos da República), provinha da própria desarticulação entre as regiões produtivas do país. Em função da ausência de infra-estruturas de comunicações e transportes que pudessem dinamizar os fluxos de pessoas, bens, mercadorias e moedas no espaço nacional, existiam "regiões monetárias isoladas" no território. Dada essa desarticulação, a própria legislação referente ao sistema bancário procurava se adequar às realidades regionais, autorizando os mais importantes Bancos de cada Estado a emitir títulos de crédito e bilhetes bancários, que funcionavam como moedas locais ou regionais.

Era o tempo dos "bancos regionais emissores", como denominou-os Ary Bouzan (1971), através dos quais era possível a "emissão de notas inconversíveis em regiões bancárias exclusivas", como nota ainda Yttrio Costa Neto (2004:16).

Além de ser um fruto dessa falta de integração, ou de "maturidade circulatória" do território (TRAVASSOS, 1942:158), a existência dos "bancos regionais emissores" era também conseqüência da ausência de uma autoridade monetária nacional constituída' (o que entenderíamos hoje como um "Banco Central”). Não

\footnotetext{
${ }^{1}$ Dada a importância da noção de autoridade monetária para o tema da tese, faz-se necessário defini-la. É possível entendê-la como o conjunto de instituições públicas que se responsabiliza "pela execução da política financeira do governo e pela emissão de papel moeda posta em circulação"(BIDERMAN, 2006:41). Além do rigor no controle da moeda, "cabe-lhe também a responsabilidade de fiscalizar e controlar a atividade de todas as instituições financeiras"(BIDERMAN, 2006:41-42) num determinado território.
} 
havendo esta autoridade monetária, tornava-se bastante difícil o estabelecimento de políticas monetárias e financeiras verdadeiramente nacionais.

Os bancos existentes necessitavam manter cerca de $50 \%$ de seus ativos entesourados, já que em caso de uma grande crise - ou de um processo generalizado de inadimplência em sua área de atuação - não haveria uma instituição que pudesse cuidar do saneamento financeiro do sistema. Uma autoridade monetária constituída serviria para garantir "empréstimos em última instância", e evitaria essa porcentagem grande de ativos congelados por parte dos bancos.

Mas alguns conteúdos do território, específicos em cada região, trabalhavam também para aumentar essa dificuldade de desenvolvimento da intermediação financeira no país.

No caso de São Paulo, apesar de haver já um dinamismo econômico robusto, desde ao menos as duas últimas décadas do século $\mathrm{XIX}$, os principais circuitos geradores de excedentes à época (isto é, os circuitos de exportação do café) se utilizavam de outros atores (que não os bancos) como forma de financiar a produção. Era o caso principalmente dos chamados "comissários do café", que acabaram gerando uma rede de concessão de créditos que não estimulava a atividade bancária no Estado.

Eram os comissários que "faziam a ligação entre os agricultores e o sistema financeiro. Esses homens de negócios enviavam escravos, implementos agrícolas, roupas e alimentos para os agricultores em conta-corrente, para serem pagos com a venda do café" (SCHULTZ, 1996:49) ${ }^{2}$. De maneira resumida, podemos dizer que a figura dos comissários era necessária, pois:

\footnotetext{
${ }^{2}$ Como nos lembra a historiadora Marisa Midori Deaecto (2002:98 e ss.), além dos "comissários" do café, surgem também neste período os "agentes comerciais" e os "importadores", que dariam maior espessura à divisão social do trabalho no estado de São Paulo, e em especial em sua capital.
} 
a) conheciam bem a rede de produtores nas áreas de cultivo do interior e fornecendo crédito a vários fazendeiros - representavam um risco menor para o sistema financeiro;

b) dada a ausência de uma rede bancária, e dada a escassez do meio circulante, os comissários também funcionavam como uma espécie de catalisador do sistema produtivo nas regiões produtoras de café, já que tanto a comercialização das safras, quanto o suprimento de insumos para os fazendeiros, eram realizados muitas vezes através deles, sem a utilização de numerário (moedas) ${ }^{3}$

Também com relação às necessidades de consumo do "povo" que se formava nas áreas plantadoras de café (BEIGUELMAN, 1968), o crédito bancário não era necessidade premente. Em São Paulo (assim como nos demais Estados produtores da rubiácea) boa parte das necessidades de consumo dos trabalhadores agrícolas era suprida nas próprias fazendas, no sistema conhecido como "armazém". Os "armazéns" serviam como fornecedores de crédito principalmente para os colonos, que dirigiam-se a este tipo de estabelecimento dentro das fazendas para realizar suas necessidades de consumo. O crédito era concedido pelo desconto dos proventos dos próprios colonos, isentando a transação da utilização de moedas. A relação era basicamente contábil (crédito/débito). ${ }^{4}$

No que diz respeito à ausência de uma rede de concessão de créditos bancários na Amazônia, instalou-se também um mecanismo semelhante ao dos "comissários do

\footnotetext{
${ }^{3}$ Mas não só pela existência dos comissários (sistema de ações) que o sistema bancário tinha dificuldade em se desenvolver no território (mesmo em uma região economicamente dinâmica, como eram os Estados do Rio de Janeiro e de São Paulo à época): também pelas dificuldades relacionadas ao "estabelecimento de garantias" para os empréstimos os bancos tinham sua ação inibida. As duas formas principais de caução existentes (as hipotecas das terras e os escravos) eram bastante precárias. As hipotecas sobre a propriedade da terra não eram boa garantia para os empréstimos por se constituírem - como assevera Celso Furtado $[1955,1994)-$ num "fator de produção abundante"; portanto, a terra não figurava como um padrão estável de riqueza, e não servia eficientemente como garantia para as operações bancárias, atividades "avessas ao risco". Em relação aos escravos como garantia, pode-se dizer que este "ativo" também não era funcional, pois além da evolutiva tendência de torná-lo mão-de-obra livre no país, "podia morrer, fugir, ou ser vendido sem a permissão do credor"(SCHULTZ, 1996:50).

${ }^{4} \mathrm{Na}$ maior parte dos casos, os colonos encontravam grandes dificuldades para equilibrar esta relação, que pendia sempre para o favorecimento do fazendeiro, dono do armazém. (SCHULTZ, 1986). Também Pierre Monbeig $(1952,1984)$ descreve que, na maior parte das vezes que os colonos do café tomavam dinheiro emprestado dos bancos, não conseguiam saldar suas dívidas.
} 
café" em São Paulo. O chamado "sistema de aviamento" foi a forma financeira encontrada para o suprimento de créditos aos circuitos de extração e produção da borracha, como nos lembra Roberto Santos (2002). Em termos gerais, o aviamento era

“(...) um sistema de crédito informal, pelo qual um indivíduo (aviador) adiantava ao produtor (aviado) certa quantidade de bens de consumo e algum dinheiro, para que o produtor os utilizasse durante o período da espera da safra extrativa. $O$ aviador registrava o débito do produtor, o qual deveria resgatá-lo ao fim da safra com a produção extrativa. E assim como os pequenos e médios "aviadores" aviavam o produtor, também os médios e pequenos "aviadores" se aviavam junto a grandes firmas "aviadoras", pagando os seus débitos com produção extrativa e agrícola. E, finalmente, essas grandes firmas "aviadoras" levavam para o mercado internacional ou nacional as produções extrativas e agrícolas, daí recebendo bens de consumo e bens de produção mediante pagamento ao câmbio do dia"(SANTOS, 2002:224).

Também aqui, portanto, um mecanismo meramente contábil - e não propriamente bancário - é que permitia que as atividades extrativas se realizassem na Amazônia, sem a necessidade do desenvolvimento de um sistema creditício mais sofisticado. Roberto Santos (op. cit:224/225] mostra-nos ainda que o aviamento criou uma poderosa rede de relações (a "rede de aviamento"), que "se estendeu a quase todo o território amazônico", e que "projetava os seus órgãos até as últimas capilaridades do tecido potâmico da Região, se lá estivesse localizado um produtor e fosse possível retirar um produto extrativo".

$\mathrm{Na}$ Bahia também não foram poucas dificuldades as encontradas para o estabelecimento perene da atividade bancária. Em seu estudo sobre a evolução do Banco da Bahia (fundado no ano de 1858), Thales de Azevedo e Edilberto Viera Lins (1969) mostram que, apesar do relativo sucesso da industrialização do Estado (na passagem do século XIX para o XX), vários fatores atrasavam 0 desenvolvimento financeiro da região. Dentre os principais, destacam:

a) as flutuaçóes dos preços dos produtos ali comercializados (principalmente os produtos agrícolas, como a cana-de-açúcar, a borracha etc.); 
b) o reduzido mercado consumidor para os bens industrializados e comercializados no Estado; como notam os autores,

“(...) não podia existir um mercado para a indústria que se formava na Bahia. As cidades maiores eram (...) as da área açucareira, em que a massa da população constituía-se de antigos escravos e seus descendentes e da plebe paupérrima de artesãos, trabalhadores das construções civis e dos serviços públicos, quitandeiros e vendeiros domésticos, pequenos funcionários burocráticos, quadro que se reproduzia em escala menor e ligeiramente melhor na capital. No resto do território existia um número limitado de fazendeiros, comerciantes e agentes das firmas exportadoras, um reduzido funcionalismo público e a multidão ainda mais pobre, subsistindo da sua própria produção alimentar e de um limitado comércio"(AZEVEDO e LINS, 1969:190-191);

c) e finalmente, um terceiro fator, ligado diretamente às técnicas de transporte à disposição dos sistemas produtivos locais. Para Azevedo e Lins lop. cit., 1969:196), na época, “o progresso do Estado é prejudicado pela deficiência dos meios de transporte, cuja rede ferroviária pouco aumentava, enquanto as estradas carroçáveis continuavam precárias e pouco extensas"; "faltavam-lhe, sobretudo, meios, para drenar a sua produção das zonas cultivadas para os portos do litoral e as cidades consumidoras"(idem:197).

Estes são fatores elencados por Thales Azevedo e Viera Lins (1969) que impediam o crescimento econômico da Bahia e, conseqüentemente, o desenvolvimento de um sistema bancário regional mais robusto.

Se pensarmos na formação socioespacial brasileira da época, todas as possibilidades de desenvolvimento de uma rede bancária estavam relacionadas à captação dos excedentes gerados pelos circuitos de exportação agrícola. Porém, como lembra Yttrio Costa Neto (2006:27), “enquanto não se consolidava o crédito agrícola em termos bancários, o financiamento à lavoura era, em geral, suprido por agentes não financeiros: comerciantes ou comissários e capitalistas particulares que ofereciam adiantamentos de curto prazo, muito mais que empréstimos de longo prazo". 
Esse conjunto desarticulado, e pouco afeito ao surgimento da atividade bancária começaria a ser alterado a partir do ano de 1905, quando ocorre a primeira "reforma bancária" nacional (TRINER, 1996), que poderíamos entender como importante alteração nos conteúdos normativos do território, em relação às suas finanças. Neste ano é "fundado" pela terceira vez o Banco do Brasil (LESSA, 2000), e nele são centralizadas novas funções de controle da atividade bancária.

Além da própria modernização normativa (que, por exemplo, organiza o controle societário das instituições financeiras), a realização do "monopólio da emissão de moeda" pelo Banco do Brasil aumenta o controle do governo sobre a concessão de crédito no país (TRINER, 1996). Os fenômenos de variação do câmbio e da inflação (grandes problemas do período do "Encilhamento" ${ }^{5}$ ) são controlados, e é possibilitada a entrada da nação numa nova fase de desenvolvimento bancário.

\subsection{Os conteúdos normativos do território e a formação das primeiras redes bancárias regionais}

A re-fundação do Banco do Brasil, no ano de 1905, pode ser considerada como um evento significativo, que começa a alterar o padrão de circulação do capital financeiro no território brasileiro. Para Gail Triner, a partir deste acontecimento, foi estabelecida "a base para o moderno sistema bancário brasileiro"(1996:50). Esta re-fundação foi importante, em primeiro lugar, pela forma de organização administrativa do Banco, que passa a funcionar a partir de uma composição societária mais pulverizada, "despersonalizando" o controle da organização. Em segundo lugar, é importante destacar que o Banco do Brasil passa a ser a única instituição autorizada a emitir moeda no território, agora respaldada pelo lastro

\footnotetext{
${ }^{5}$ O encilhamento foi uma "febre de especulações" iniciada a partir da Proclamação da República (em 1889), que levou à formação "sem precedentes" de novas empresas, assim como a um aumento "rápido e brusco" de venda de ações das mesmas na Bolsa de Valores do Rio de Janeiro (GOLDSMITH, 1984:106). Como nos explica ainda Edgar Carone (1975:108), "a facilidade de numerário faz surgir um considerável número de empresas comerciais, industriais, agrícolas etc." "(...) No decorrer de todo o ano de 1890 e 1891, fundam-se sociedades ininterruptamente. Anuncia-se o projeto, obtém-se a concessão, forma-se a companhia e, antes de legalizar totalmente a sua existência, os títulos já são vendidos na Bolsa por altos preços. A sua revenda com ágio e a jogatina tornam-se normais, principalmente porque os bancos operam largamente em caução de títulos. Os "novos-ricos" surgem da noite para o dia".
} 
com ouro; antes de 1905, a existência de vários "bancos emissores regionais" dificultava sobremaneira o controle nacional da atividade creditícia e, portanto, da intermediação financeira.

Os demais bancos que surgem neste período são, na sua quase totalidade, fruto da ação direta ou indireta dos governos estaduais. Datam do início do século, por exemplo, a fundação dos primeiros bancos resultados de incentivos fiscais destes governos, sendo os principais: a) o Banco de Crédito Agrícola e Hipotecário do Estado de São Paulo (1909); b) o Banco Hipotecário e Agrícola do Estado do Espírito Santo (1911); e c) Banco Hipotecário e Agrícola de Minas Gerais, também em 1911 (COSTA NETO, 2004:34).

Com relação à topologia bancária que se formava, a bibliografia analisada permite dizer que ela era ainda bastante restrita às maiores cidades do país, localizadas em grande parte no litoral do território brasileiro. Essa topologia também servia como elemento de restrição ao uso dos serviços bancários. Como lembra Costa Neto (2004:43), "fazendeiros e colonos ainda preferiam moeda manual a depósitos bancários, basicamente porque a rede bancária não havia se expandido para as grandes áreas do interior, continuando concentrada nas grandes cidades envolvidas com o comércio exterior".

Em 1914, por iniciativa do Banco do Brasil, começam a ser implementadas algumas políticas que visavam aumentar a intermediação financeira no país. Em primeiro lugar, o Banco do Brasil promove uma política de garantia para os "empréstimos hipotecários" realizados através de sua rede de agências. Identificado como um dos principais problemas da técnica bancária, o "financiamento hipotecário"[COSTA NETO, 2004:22) esbarrava em uma série de dificuldades, principalmente relacionadas com a precificação dos ativos imóveis. ${ }^{6}$

\footnotetext{
${ }^{6}$ Era também muito difícil, à época, que as técnicas bancárias se desenvolvessem a partir de um sistema normativo um tanto quanto impreciso, assim como eram imprecisas as regras que definiam o que eram os "ativos financeiros"; assim, emprestar dinheiro com base em hipotecas de fazendas (ou outras formas de propriedade imobiliária) se constituía numa prática financeira bastante arriscada, em termos de garantia para a concessão de empréstimos.
} 
Uma segunda tentativa de modernizar a atividade bancária no território foi a política de expansão da rede de agências do Banco do Brasil. Com a preocupação de atender as áreas com menor dinamismo, são também instaladas novas agências no território, como mostra o quadro a seguir:

Quadro 1: Brasil: Interiorização das Agências do Banco do Brasil (1905-1919)

\begin{tabular}{|c|c|c|}
\hline & 1905-1915 & 1915-1919 \\
\hline $\begin{array}{l}\text { Cidades que receberam } \\
\text { Agência }\end{array}$ & $\begin{array}{l}\text { Manaus, Belém, Santos, } \\
\text { Campos (RJ), Salvador, } \\
\text { Recife, Fortaleza, Curitiba, } \\
\text { Porto Alegre e Paraíba }\end{array}$ & $\begin{array}{l}\text { Corumbá, Maceió, Aracaju, } \\
\text { Três Corações, Uberaba, } \\
\text { São Paulo, Florianópolis, } \\
\text { Natal, Ilhéus, Vitória, São } \\
\text { Luiz do Maranhão, Parnaíba, } \\
\text { Juiz de Fora, Cataguazes, } \\
\text { Santa Luzia de Carangola, } \\
\text { Ponta Grossa, Barretos, } \\
\text { Ribeirão Preto, Varginha, } \\
\text { Pelotas, Belo Horizonte, Jaú, } \\
\text { Rio Grande, Bagé, Joinville e } \\
\text { Livramento }\end{array}$ \\
\hline
\end{tabular}

Fonte: Yttrio Costa Neto (2004:44)

No ano de 1921, este avanço da rede de agências do Banco em direção ao interior do país acaba por instalar ao menos uma agência em cada estado da federação. Em 1928, essa rede do Banco do Brasil já contava com 73 agências, espalhadas pelo território (TRINER, 1996:66).

Além da expansão da rede de agências, uma terceira alteração se processa a partir de 1914. O Banco do Brasil inicia uma política de dotação de uma quantidade mínima de recursos financeiros em toda sua rede de agências, independentemente das capacidades locais de captação de depósitos. Cada parcela do território contaria, assim, com a possibilidade de uso do crédito bancário como forma de desenvolvimento regional. Neste sentido, mostra ainda Gail Triner, "a Agência central (no Rio de Janeiro) subsidiava regularmente a abertura de agências, através da transferência de fundos para as novas localidades. Como resultado, as agências podiam emprestar maiores quantidades do que aquelas que eram coletadas localmente. Estas transferências foram importantes para o estabelecimento de serviços bancários onde eles não eram anteriormente disponíveis"(TRINER, 
1996:66). Pode-se dizer, portanto, que há um sentido "distributivo" da ação do Banco neste período, já que se preocupa em integrar o território do ponto de vista financeiro, independentemente do nível de desenvolvimento econômico dos estados da federação.

Por último, mas não menos importante, a abertura junto ao Banco do Brasil da primeira "câmara de compensação de cheques" nacional, no ano de 1921, é um evento que também moderniza a atividade bancária. Com seus estatutos aprovados no ano de 1919, viria a funcionar dois anos depois, no Rio de Janeiro. No decorrer da década de 1920, são instaladas ainda as Câmaras nas seguintes cidades: São Paulo, Santos, Porto Alegre, Recife, Salvador, Belém e Ribeirão Preto (SAES, 1997:202). Para entendermos melhor a importância deste quarto evento destacado, podemos lembrar que

\footnotetext{
"o cheque já assumia, então, o papel de instrumento relevante para a movimentação dos saldos bancários. Por outro lado, a Câmara de Compensação permite reduzir a proporção de caixa dos bancos, uma vez que grande parte do movimento em espécie deixa de se realizar como tal, figurando agora apenas como lançamentos contábeis. Nesse sentido, é provável que tenha havido significativo aumento da capacidade de criação de moeda pelos bancos a partir de então"(SAES, 1997:202).
}

Antes de 1921, portanto, havia grandes dificuldades técnicas e organizacionais para a realização de transações interbancárias, assim como para as transações entre os consumidores e as casas comerciais (que só podiam utilizar "moeda sonante" para a compra/venda de produtos). "A Câmara central de cheques melhorou a eficiência das transações comerciais e incrementou a velocidade do dinheiro", relembra também Gail Triner (1996:66).

Outro importante evento ocorrido em 1921 foi o estabelecimento da Carteira de Emissão e Redescontos (CARED) do Banco do Brasil (na verdade, autorizada já pelo Decreto No. 4.182, de 13 de novembro de 1920). A partir da criação da Carteira, um conjunto de regulaçóes e normas mais precisas passam a balizar o comportamento dos atores financeiros. Desde então, os bancos públicos e 
privados também podem contar com títulos do Governo Federal, como garantia para a concessão de empréstimos ao público. A possibilidade de transações bancárias com títulos (principalmente do Governo Federal) imprimiria uma maior segurança à ação dos bancos, diminuindo a vulnerabilidade do sistema como um todo (COSTA NETO, 2004: 45 e ss.).

Em função da criação da Carteira de Emissão e Redescontos, os bancos nacionais passam a contar com mais garantias para suas atividades creditícias, tendo seu "status" comparável aos dos bancos estrangeiros (que sempre possuíam a possibilidade de recorrer às suas matrizes, em caso de uma crise aprofundada). ${ }^{7}$

Essa institucionalização do sistema bancário e de sua regulação, ocorrida na segunda década do século $\mathrm{XX}$, normatiza e moderniza a divisão bancária do trabalho que se instalava no território. Dentre as principais mudanças trazidas pelas novas Leis em vigor, Yttrio Costa Neto (2004:47) destaca quatro bastante importantes:

a) elas definiram as atividades que seriam entendidas efetivamente como "específicas de bancos e de casas bancárias" ${ }^{8}$;

b) com as novas normas e instituições, foram estabelecidos critérios quantitativos para a diferenciação entre os estabelecimentos bancários;

c) o funcionamento das casas bancárias passava a depender da concessão de "cartas-patente", emitidas pelo Ministro da Fazenda;

d) foi instalada também, neste contexto, a primeira regulamentação específica em relação à participação do capital estrangeiro no sistema bancário nacional.

\footnotetext{
${ }^{7}$ Como nos mostra Yttrio Costa Neto (op. cit.,2004:45), "a ausência de redesconto havia sido apontada como causa da vulnerabilidade daqueles (bancos nacionais) às crises monetárias e da preferência do público pelos bancos estrangeiros, cujas matrizes os socorriam prontamente durante emergências".

${ }^{8}$ A criação da Inspetoria Geral dos Bancos, é outro evento que aumenta a densidade normativa do espaço brasileiro, em relação ao controle das atividades bancárias. O Decreto no. 14.728, de 16 de março de 1921 reconhece também a "atividade bancária como dotada de certas especificidades", e daí merecer uma legislação específica (SAES, 1997:203). Segundo ainda Flavio Saes (1997:203), "o regulamento definia as atividades entendidas como específicas de bancos ou casas bancárias, a saber, o comércio, por conta própria ou de terceiros, de: ouro ou prata em moeda, pó ou barra; títulos da dívida pública nacional ou estrangeira e títulos de empresas de qualquer natureza, efeitos do comércio e outros valores negociáveis; empréstimos de qualquer espécie; operações de câmbio, depósitos de valores de qualquer natureza, abertura de contas correntes, descontos e redescontos, quaisquer operações bancárias atinentes ao movimento de crédito".
} 
Como então evoluiu a divisão bancária do trabalho, neste período da gênese do moderno sistema bancário brasileiro?

Uma primeira transformação importante ocorrida após as reformas de 1921 foi o processo de estatização de vários bancos comerciais privados, abertos no começo do século (a partir de garantias dos governos estaduais). Em 1919 o Banco de Crédito Real de Minas Gerais (Credireal) e o Banco Hipotecário e Agrícola do Espírito Santo são encampados por seus Estados. O Banco de Crédito Hipotecário e Agrícola do Estado de São Paulo (BCHASP) é comprado no ano de 1926, e passaria a se chamar Banco do Estado de São Paulo (BANESPA). ${ }^{9}$

Ainda com relação à divisão bancária do trabalho que se instalava, pode-se dizer que, a partir de meados da década de 1920, a legislação financeira torna-se mais restritiva em relação à atuação de bancos estrangeiros no território. Uma das mais importantes medidas, que acabaram por desestimular a presença de bancos estrangeiros no território, foi a exigência de capitais mínimos para a instalação de suas agências. Como mostra Yttrio Costa Neto (2004:47), "suas sucursais no país não poderiam ter capital inferior a nove mil contos de reis".

Desde então, a participação desses atores na intermediação financeira diminui sensivelmente. Se tomarmos os dados dos depósitos totais no sistema bancário, vemos que a participação estrangeira diminui sensivelmente: de uma parcela de 44,9\% dos depósitos no ano de 1919, passa a ser de apenas 24,5\% no ano de 1932.

Essa tendência se acentuaria após a outorga das Constituições dos anos de 1934 e 1937, quando houve "progressiva nacionalização dos bancos estrangeiros e a exclusividade de nacionais no controle acionário de instituições bancárias e companhias de seguros" (COSTA NETO, 2004:48). Conforme mostra Fernando Costa (1988:234), as Constituições acima referidas impuseram uma legislação

\footnotetext{
${ }^{9}$ Para Costa Neto (2004:39), "sob perspectiva, portanto, os primeiros bancos estaduais e o BB (Banco do Brasil) surgiram como conseqüência da frustração de iniciativas que, por intermédio de instituições privadas incentivadas pelos governos, procuravam, respectivamente, estabelecer o crédito especializado em financiamentos hipotecários e agrícolas, e aperfeiçoar a circulação monetária e o crédito em geral".
} 
mais restritiva com relação ao funcionamento destes bancos; em 1941, o DecretoLei de 9 de abril impõe prazos para a nacionalização dos bancos estrangeiros instalados no país. Estas normas vão tornando, paulatinamente, mais difíceis as ações de instituições financeiras forâneas em território nacional.

Esse novo modus operandi da atividade bancária levou a uma expressiva proliferação de bancos no país, principalmente durante o período da Segunda Grande Guerra (entre os anos de 1939 e 1945). Segundo Fernando Costa (1988:238), eram nada menos que 663 o número de matrizes de bancos no território brasileiro, no ano de 1944. Também neste ano havia cerca de 2,7 agências por instituição bancária, número bastante baixo para os padrões internacionais da época. Significa dizer que o controle do sistema de ações financeiro no período era bastante pulverizado, ao contrário do que veríamos ocorrer a partir de 1945.

Podemos afirmar que são dois os principais dados do período que autorizaram esse crescimento do número de atores do sistema bancário:

a) os conteúdos normativos do espaço: a legislação vigente não estabelecia critérios rígidos para o controle da proliferação de bancos; exigia-se também níveis reduzidos de recursos de capital para a entrada de novos atores no sistema bancário, o que facilitava o crescimento do número de instituições/agências;

b) as possibilidades técnicas do período: segundo o argumento de Fernando Costa (1988:235), eram poucos os requisitos técnicos e organizacionais necessários para a instalação de novas agências no território.

Este quadro autoriza falarmos de uma "fase competitiva" (COSTA, 1988) do sistema bancário brasileiro, antes do ano de 1945. Ao contrário do que comumente se vê em situações de oligopólio, o controle do sistema era sensivelmente desconcentrado. Esta situação só viria a ser alterada a partir da instalação da Superintendência da Moeda e do Crédito (a SUMOC), no ano de 1945, que inicia políticas de concentração do sistema bancário nacional. 


\subsection{Os novos sistemas técnicos do território e o surgimento da Caixa Econômica do Estado de São Paulo}

Se por um lado o desenvolvimento da atividade bancária é bastante sensível aos conteúdos normativos do espaço, também os conteúdos técnicos influenciam essa atividade. Na Amazônia, como mencionamos, a atividade bancária foi dificultada pela existência de um sistema de controle da produção que pouco necessitava do crédito em sua modalidade bancária. Também ali a distribuição da população era mais dispersa, constituindo grandes "vazios urbanos", como nos lembra Pedro Geiger (1963:32); as cidades eram "exceções", lembram-nos ainda José Raimundo Vergolino e Gustavo Maia Gomes (2002:252). Daí podermos falar que as densidades técnicas da região eram menores.

Por outro lado, no estado de São Paulo, o processo de urbanização e a divisão social do trabalho ganham maior incremento com o fenômeno da industrialização que a região conhece nesse mesmo período. Um dos dados que nos permite entender melhor o desenvolvimento deste fenômeno, e o porquê das primeiras redes bancárias no território brasileiro terem aqui se desenvolvido, diz respeito à evolução dos sistemas técnicos da região.

Até o ano de 1940, um dos principais sistemas técnicos que se difundiu no território brasileiro foram as redes ferroviárias.

Tabela 1: Brasil - Evolução do Sistema de Movimento Ferroviário (1854-1945)

\begin{tabular}{|l|r|r|r|}
\hline Períodos & $\begin{array}{c}\text { Extensão da rede ao } \\
\text { final do período (km) }\end{array}$ & $\begin{array}{c}\text { Quilometragem } \\
\text { acrescentada ao final } \\
\text { do período }\end{array}$ & $\begin{array}{c}\text { Quilometragem } \\
\text { média anual } \\
\text { acrescentada }\end{array}$ \\
\hline $1873-1888$ & $9.320,9$ & $8.388,7$ & 524,2 \\
\hline $1889-1907$ & $17.605,2$ & $8.284,3$ & 436,0 \\
\hline $1908-1914$ & $26.062,3$ & $8.437,1$ & $1.208,1$ \\
\hline $1915-1928$ & $31.851,2$ & $5.788,9$ & 413,5 \\
\hline $1929-1934$ & $33.106,4$ & $1.255,2$ & 209,2 \\
\hline $1935-1938$ & $34.206,6$ & $2.355,4$ & 588,9 \\
\hline $1939-1945$ & $35.280,0$ & $1.073,4$ & 153,3 \\
\hline
\end{tabular}

Fonte: Suzigan e Villela (1973) 
Como mostram os estudos de Pierre Monbeig $(1952,1984)$, Fernando Azevedo (1950), Odilon Matos (1974), Flavio Saes (1981), entre outros, o estado de São Paulo foi a parcela do território que mais teve sua rede ferroviária desenvolvida, no período de maior expansão deste sistema técnico. Essa precoce base técnica acabou por catalisar - junto com os fatores migratórios, agrícolas e industriais -um processo dinâmico de urbanização, que tanto criou um poderoso hinterland para a cidade de São Paulo, como credenciou a região para se consolidar como o centro da divisão territorial do trabalho que se instalava.

Com essa nova forma de organização das atividades produtivas no estado de São Paulo, "as velhas práticas do crédito, baseadas em relações diretas e afetivas, eram assim substituídas por uma organização sem dúvida mais eficaz" (MONBEIG, 1952, 1984:111). Atento, portanto, às necessidades diferenciadas de financiamento que trazem as alterações da base técnica do espaço, asseverava ainda Pierre Monbeig (1966:1516): a difusão das "técnicas do maquinismo" leva à utilização dos "mecanismos financeiros".

O que se pode dizer da rede bancária que se formava no Estado? Quais suas principais características? A bibliografia analisada é unânime no destaque da diminuição da importância dos bancos estrangeiros, nas três primeiras décadas do século (SAES, 1986b; 1997; COSTA, 1988; COSTA NETO, 2001). Se atentarmos para a tabela abaixo, podemos ter uma dimensão bastante aproximada disto, no que diz respeito às variáveis depósitos/empréstimos realizados no estado de São Paulo entre 1919 e 1928.

Tabela 2: São Paulo: Evolução do Sistema Bancário (valores em mil réis) (1919-1928)

\begin{tabular}{|l|r|r|r|r|r|r|r|r|}
\hline & \multicolumn{9}{|c|}{1919} & \multicolumn{5}{|c|}{$\mathbf{1 9 2 8}$} \\
\hline Bancos & DEPÓSITOS & \% & EMPRÉSTIMOS & \% & DEPÓSITOS & \% & EMPRÉSTIMOS & $\%$ \\
\hline Estrangeiros & $535.300: 335$ & 70,6 & $377.298: 634$ & 62,4 & $670.592: 125$ & 25,4 & $704.522: 175$ & 28,8 \\
\hline $\begin{array}{l}\text { Nacionais } \\
\text { na capital }\end{array}$ & $217.767: 692$ & 28,7 & $223.427: 980$ & 37,0 & $1.866 .454: 438$ & 70,6 & $1.590 .992: 424$ & 65,2 \\
\hline $\begin{array}{l}\text { Nacionais } \\
\text { no interior }\end{array}$ & $5.655: 547$ & 0,7 & $3.846: 088$ & 0,6 & $104.847: 447$ & 4,0 & $146.560: 834$ & 6,0 \\
\hline TOTAIS & $758.723: 574$ & 100 & $604.572: 702$ & 100 & $2.641 .894: 010$ & 100 & $2.442 .075: 433$ & 100 \\
\hline
\end{tabular}

Fonte: elaboração própria a partir de SAES (1986b pp. 229 e 238). 
Reflexo das já citadas alterações das normas bancárias do território, há sensível perda do controle estrangeiro dos depósitos e empréstimos realizados no Estado ${ }^{10}$. Outro dado digno de nota é a distribuição das operações bancárias. Ainda que passemos de 0,7\% dos depósitos (e 0,6\% dos empréstimos) em 1919 para cerca de 4,0\% (e 6,0\% dos empréstimos, respectivamente) no ano de 1928, é bastante forte a concentração das atividades bancárias na capital do Estado.

É neste contexto que vão surgir as primeiras agências da Caixa Econômica do Estado, no ano de 1917. Como lembra-nos documento da Caixa à época, "a progressão econômica do estado de São Paulo reclamava caixas próprias para amealhar as sobras da poupança de sua gente laboriosa"(CAIXA ECONÔMICA, 1952:45) ${ }^{11}$.

As agências são criadas "inicialmente nas principais cidades do Estado, como São Paulo, Santos, Campinas e Ribeirão Preto"(NOSSA CAIXA, 2002:46). Em apenas dois anos de funcionamento, são colocadas a funcionar mais 52 agências, além destas quatro originais, perfazendo uma considerável rede de coleta de poupanças no interior do Estado (ver Mapas 1 e 2).

O que importa destacar é que são pelo menos dois conteúdos do território que influenciam esta distribuição inicial da instituição: a) praticamente todas as agências são criadas em municípios servidos pela rede ferroviária do Estado; b) através da Lei no. 1.544 de 1917, era também desejado que as agências da Caixa fossem criadas junto às Coletorias de Rendas Estaduais (NOSSA CAIXA, 2002:46), no sentido de otimizar os fluxos de recursos públicos do Estado. Esta topologia não se alteraria muito no ano de 1930, quando mais 27 agências foram incorporadas à rede da Caixa (Mapa 2).

\footnotetext{
10 Antes da implementação das restrições normativas que fizeram diminuir a atuação dos bancos estrangeiros no país, Yttrio Costa Neto (2004) destaca três fatores envolvidos na forte presença de bancos estrangeiros nas duas primeiras décadas do século XX: 1) havia grande quantidade de imigrantes "recém-chegados" ao país neste período, que preferiam depositar seus recursos em bancos de seus respectivos países de origem; 2) boa parte dos brasileiros que se utilizavam dos serviços bancários, trabalhavam com comércio exterior e realizavam com maior facilidade estas operações nos bancos estrangeiros aqui instalados; 3) por fim, "muitos brasileiros, provavelmente, também confiavam mais nos bancos estrangeiros, por sua reputação bem firmada e grandes reservas no exterior, do que nos bancos nacionais, menores e geralmente mais novos"[COSTA NETO, 2004:30).

${ }^{11}$ No que tange aos conteúdos normativos do território, a partir do Decreto no. 2.765 , de 19 de janeiro de 1917, é regulamentada a ação das Caixas Econômicas no território, e no mesmo ano é aberta a agência-matriz, na cidade de São Paulo, da Caixa Econômica do Estado.
} 


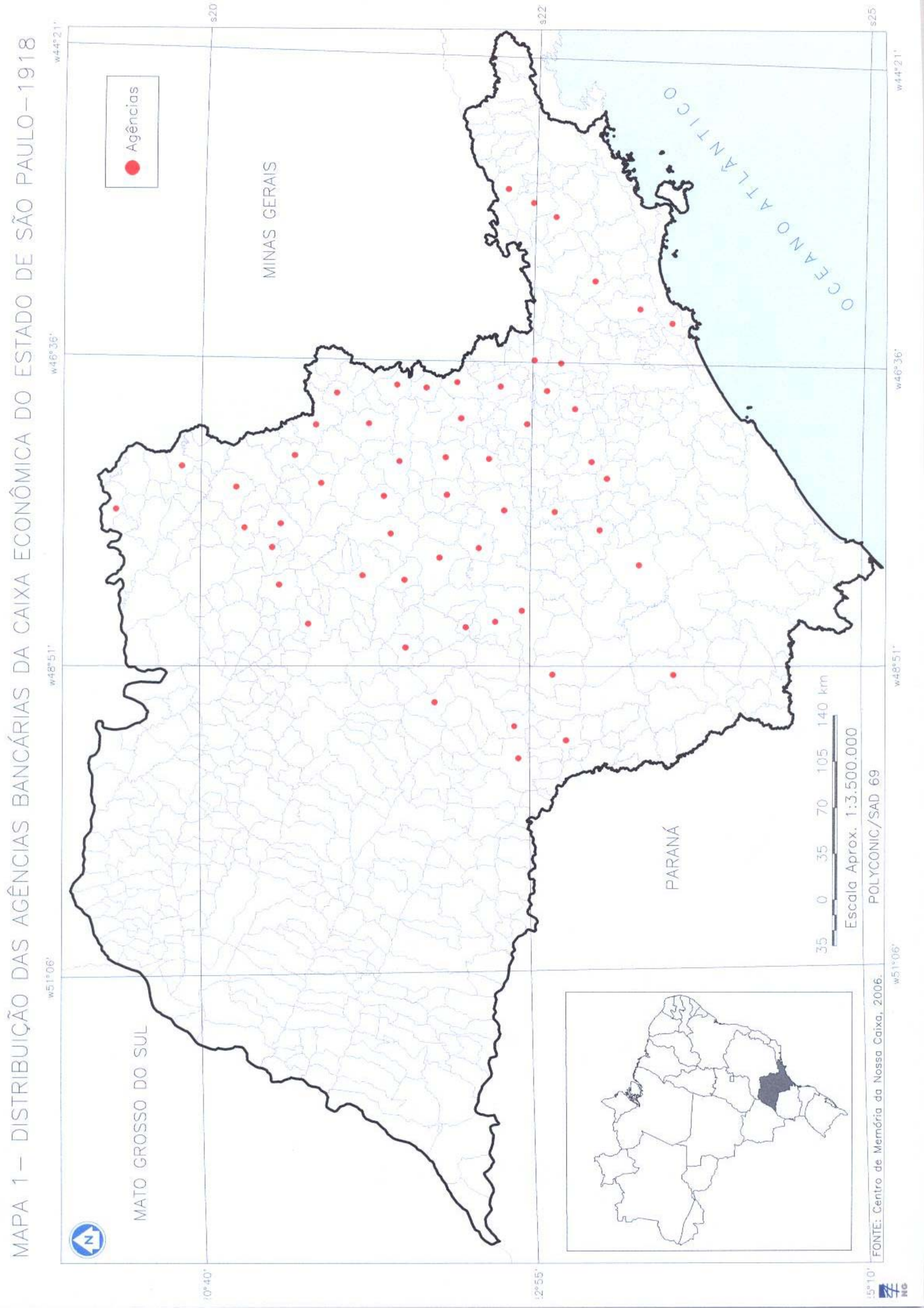




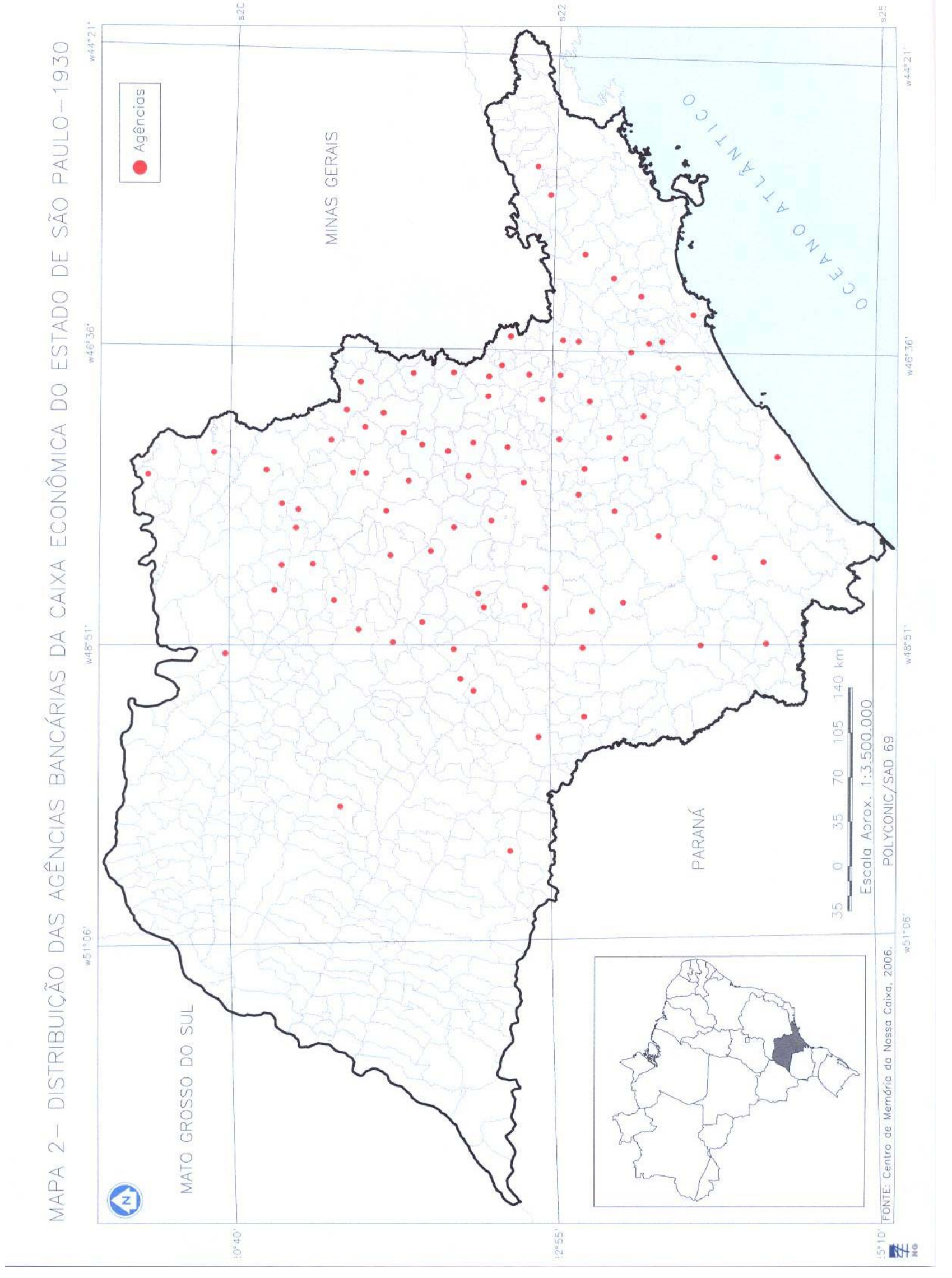

31 
Há, portanto, uma relação bastante próxima entre a burocracia estatal em formação (e a rede de serviços públicos por ela prestada) e a difusão das agências da Caixa Econômica do Estado. Vale lembrar que não só autarquias do Governo Estadual são criadas neste período, mas também uma série de outras empresas públicas para a prestação de serviços urbanos, como companhias de iluminação pública, companhias de transportes (bondes e "carris"), empresas de água e esgoto, de telefonia, eletricidade, etc. (SAES, 1985:82-83).

Junto das empresas públicas vem também o funcionalismo, os fluxos de recursos públicos do Tesouro (municipais e estadual) e a própria - já mencionada necessidade de coleta de impostos nas cidades. A Caixa Econômica expande suas atividades justamente em função destes fixos e fluxos ligados às empresas públicas.

No que diz respeito à qualidade de sua ação, as Caixas Econômicas sempre "tiveram motivação mais social e política do que propriamente econômica, pois era restrito o âmbito de sua atuação como entidades de crédito"(COSTA NETO, 2004:13) ${ }^{12}$. E completa ainda o autor:

\begin{abstract}
"Sua função era promover ambiente seguro e remunerador para as pequenas economias, de forma a estimular as classes populares a economizarem parte de seus rendimentos, precavendo-se de qualquer acontecimento futuro, quando fosse necessária alguma soma em dinheiro; e prover auxílio adicional, a juros abaixo dos praticados no mercado, quando aquelas economias fossem insuficientes"(COSTA NETO, 2004:14).
\end{abstract}

Estes seriam, em linhas gerais, os conteúdos do território que acabaram por condicionar a expansão inicial da rede de agências da Caixa Econômica do Estado. As práticas financeiras de auxílio à produção agrícola, assim como às demais atividades produtivas do território era função creditada ao Banco do Estado de São Paulo (BANESPA) na região (COSTA, 1988).

\footnotetext{
${ }^{12}$ Com relação à sua função de captadora da poupança das populações, destaca também o referido documento que “(...) o 'pé-de-meia' da população, colocado sob a égide do poder público, acentuava o seu caráter privilegiado de 'caixa garantida', para distinguir-se de qualquer outra entidade de crédito, pois as operações nela realizadas estavam isentas dos ônus fiscais, notadamente do imposto do selo, vigente naqueles dias. $E$, graças a tal a aparelho, o povo foi-se educando com eficiência nos sábios princípios da poupança" (NOSSA CAIXA, 2002:4).
} 


\section{CAPítulo 2: A Renovação da Base Técnica do Território e o Moderno Sistema Bancário}

A partir do ano de 1945, várias são as alterações nos conteúdos do território, induzidas principalmente pela intervenção estatal na economia (SUZIGAN, 1976). É promulgada uma nova Constituição (em 1946), que altera sensivelmente os conteúdos normativos do território brasileiro. A estrutura tributária e fiscal do país é também renovada, imprimindo uma nova realidade para as atividades públicas e privadas desenvolvidas no território (OLIVEIRA, 1991b). A diminuição da dependência das exportações (com o concomitante desenvolvimento de um mercado interno) engendrou ainda um novo processo de "substituição de importações", mais dinâmico que aquele iniciado a partir do findar da primeira grande guerra (TAVARES, 1978).

Os sistemas financeiro e bancário brasileiros conheceram uma série de transformações, como causa e conseqüência dos eventos que tiveram início em 1945. Tavares e Carvalheiro (1985:30) lembram que "o sistema bancário expandiu consideravelmente suas atividades no pós-guerra, principalmente devido ao crescimento da renda urbana no país, que era conseqüência da própria expansão industrial”.

Sob um clima de expansão do fenômeno da inflação, o sistema bancário brasileiro conhece um desenvolvimento expressivo, mas "desordenado" (PASSOS, 1973). Raymond Goldsmith (1986:265) nos lembra que a partir desta data, "o sistema bancário expandiu-se rapidamente em termos de agências, funcionários e prédios". Esta expansão deu-se grande parte em função de uma necessidade de aumentar a captação de poupança (depósitos) junto aos agentes econômicos, principalmente nas médias e grandes cidades que começavam a se formar no território.

Data desta época ainda a construção de uma série de novos sistemas de engenharia [de transportes, geração de energia, serviços urbanos) no território, que alteram 
sensivelmente seus conteúdos técnicos. Concomitantemente, são aprimoradas as infra-estruturas financeiras brasileiras. Quais os principais sistemas técnicos acrescentados ao espaço nacional neste momento? Que relação teria esta criação de sistemas de engenharia com o surgimento da Superintendência da Moeda e do Crédito (1945) e do Banco Nacional de Desenvolvimento Econômico (o BNDE, em 1952)?

\subsection{A construção de sistemas de engenharia e a intervenção do Estado}

Até o período da Segunda Guerra Mundial, apesar da formação de núcleos urbanos dinâmicos em alguns pontos do espaço nacional, o Brasil tem uma estrutura territorial que pouco contribuía para sua integração efetiva. Como nos lembra Pedro Geiger (1963:104), neste tempo "não existe uma rede urbana única, nacional, pois a fragmentação herdada do período colonial põe à mostra, ainda, as linhas de separação". Esta desarticulação pode ser verificada ainda no que diz respeito aos sistemas de movimento ${ }^{13}$, assim como no que tange aos sistemas de produção de energia do País.

Em relação ao sistema de movimento, podemos dizer que começam a ser substituídos os modais ferroviário e aquaviário pelos sistemas de movimento rodoviário e aeroviário, ainda que "desordenadamente" (RIBEIRO, 1956:176). A topologia destes sistemas era, até esta época, extravertida e desarticulada internamente. Extravertida pois todas as redes-suporte (principalmente a rede ferroviária) aqui implantadas, desde o final do século XIX, serviram principalmente para o escoamento da produção de gêneros agrícolas para os mercados internacionais (ARAúlO FILHO, 1956). Desarticulada pois, como se tratavam de redes de pouca conexão umas com as outras, cada região do país tinha uma vida

\footnotetext{
13 O conceito de "sistemas de movimento" foi criado por Jean Gottmann, em seu La Politique des États et leur Géographie (1952). Para o Autor, os "sistemas de movimento" é que possibilitariam todos os processos de circulação (de pessoas, bens, idéias) que animam a vida regional das nações. O outro "par conceitual" no sistema teórico de Gottmann seria o de "sistemas de resistência ao movimento"; estes, por seu turno, seriam responsáveis pela geografização (ou não) dos fluxos trazidos pelos "sistemas de movimento", em cada região. A utilização dada para o conceito no presente trabalho, porém, é distinta. A noção de "sistema de movimento" aqui empregada diz respeito aos diferentes modais de transporte disponíveis para a organização e uso do espaço geográfico (SANTOS e SILVEIRA, 2001: 126 e ss.; CONTEL, 2001).
} 
de relações mais densa com o exterior, em detrimento muitas vezes de nosso mercado interno. A este tipo de organização do espaço geográfico, convencionouse chamar de espaços derivados (SANTOS, 1972). ${ }^{14}$

Mas mesmo voltada em grande parte para o exterior, a formação da rede urbana consolida um processo de industrialização nas cidades brasileiras, principalmente nas Regiões Sul e Sudeste do país. Em função desta nova realidade, ocorre expressiva "expansão das infra-estruturas necessárias ao crescimento da atividade industrial, particularmente em São Paulo e Minas Gerais"(GEIGER e DAVIDOVITCH, 1983:21).

O ritmo de crescimento da população também é considerável. Entre os anos de 1946 e 1956, a população brasileira cresce cerca de 2,17\% ao ano; entre 1957 e 1964, essa percentagem é de 3,03 ao ano (GOLDSMITH, 1986:221). Ainda segundo o autor, "entre o censo de 1940 e o de 1960 a população urbana cresceu em 18,5 milhões de habitantes, ou $143 \%$, ao passo que a população rural limitou-se a 10,5 milhões, ou 37\%"(GOLDSMITH, op. cit:222).

É a aceleração do crescimento da indústria, porém, que nos chama ainda mais a atenção. Para os mesmos períodos de 1946/1955 e 1956/1964, a produção industrial cresce $9,10 \%$ e $8,30 \%$ ao ano, respectivamente (GOLDSMITH, op. cit::221). Com relação à estrutura da industrialização, podemos dizer que se tratava de um processo mais pulverizado, fundado em unidades produtivas bastante dependentes de seus mercados locais ou regionais (JAMES, 1935; BARROS DE CASTRO, 1971; MAMIGONIAN, 1976). Este arranjo regionalizado parece ser também outro condicionamento imposto pela compartimentação do território ${ }^{15}$.

\footnotetext{
${ }^{14}$ Inspirado no conceito de "paisagens derivadas" de Max Sorre, Milton Santos (1972) nos mostra que a difusão de inovações técnicas nos países da periferia do sistema capitalista muitas vezes aumenta a dependência destes com as necessidades da metrópole com a qual seus laços (comerciais, políticos) são estreitados. Para o autor (SANTOS, 1972:265), "do fato que são derivados, esses espaços se organizam ou se reorganizam ao serviço de interesses distantes: seu planejamento (aménagement) é função de necessidades exógenas e depende de parâmetros importados, copiados de sistemas representativos de interesses distantes".

${ }^{15}$ A compartimentação do território pode ser considerada como resultado do próprio processo de formação "espontânea" das regiões. Faz-se necessário diferenciar a compartimentação do espaço, do atual processo de fragmentação, típico do processo de globalização. A fragmentação pode ser entendida como uma cisão intencional do uso do espaço, provocada pelas vicissitudes das firmas privadas, e de seu comportamento corporativo. Ver Santos e Silveira (1996) e Santos (2000).
} 
Com relação à divisão territorial do trabalho que se instala, é também possível afirmar que entramos em outro período histórico, por dois principais motivos: a) forma-se um efetivo mercado interno para os bens industriais (FURTADO, 1959, 1995), que diminui a dependência da vida de relações do território com os fluxos provenientes do exterior; e b) consolida-se a mudança do centro dinâmico da economia nacional para o Estado de São Paulo (BECKER e EGLER, 1993). No que diz respeito aos circuitos produtivos, as atividades agro-exportadoras deixam paulatinamente de ser o principal elemento de geração de riqueza no país, sendo substituídas por atividade ligadas aos consumos urbanos como: alimentação, vestuário, habitação, serviços de saúde e atividades administrativas, entre outros.

Neste período de mudanças importantes da vida nacional, assistimos à formação de um meio técnico mais complexo em parcelas selecionadas do espaço nacional. São criadas, assim, novas necessidades de investimentos públicos, para sustentar essa expansão de sistemas técnicos mais sofisticados, complexos, no território brasileiro $^{16}$. Segundo o economista Fernando Costa (1988:267), eram principalmente para a construção de infra-estruturas energéticas, de "serviços básicos" e de transportes que vão se tornar necessárias novas instituições financeiras públicas, neste mesmo período.

Deste novo quadro em formação, podemos ressaltar dois dados da infra-estrutura do território que estão na base da possibilidade da formação de um meio técnico dinâmico: os novos sistemas de geração de energia elétrica, e os novos circuitos da industrialização do território. Pareceu-nos importante destacar estes dois novos conteúdos do território, pois eles terão também relação direta com a formação de nosso moderno sistema bancário.

16 Como nos lembra Luigi Fray (1961:215), “o progresso técnico leva a necessidades crescentes de intervenção por parte dos órgãos públicos, na qualidade de ofertantes de meios de financiamento, por motivos diversos". 


\subsection{A geração de energia: base para a urbanização e a industrialização substitutiva}

A história de todos os países que se industrializaram é - do ponto de vista de suas infra-estruturas energéticas - ligada diretamente ao incremento das necessidades de geração e transmissão de energia, lembra-nos Gerald Manners [1964, 1976). "Petróleo, gás e eletricidade desabrocham no contexto da economia mundial do pós-guerra", assevera ainda Jean-Marie Martin (1992:62), e fazem parte das possibilidades que o novo período histórico coloca à disposição das nações para o incremento de suas respectivas matrizes energéticas. ${ }^{17}$

Conforme destaca Flavio Saes (1986a), o crescimento urbano verificado nas cidades brasileiras começa a exigir investimentos em serviços públicos nas cidades: transportes urbanos, serviços de saneamento e urbanismo, iluminação pública etc. E praticamente todos os novos equipamentos instalados no território, a bem da verdade, são grandes consumidores de energia (como é o caso das unidades fabris, da iluminação pública urbana, entre outros). Daí uma enorme demanda gerada, sobre uma insuficiente capacidade energética instalada.

Segundo Hugo Schlesinger (1958), as principais atividades produtivas que passam a demandar uma quantidade maior de energia, já na década de 1950, eram:

a) atividades industriais: indústria do fumo, de materiais elétricos, couros, cerâmica, algodão, bebidas, produtos químicos/farmacêuticos, produção de plásticos, metais, bens de fabricação/máquinas, automóveis e produção de cimento;

\footnotetext{
${ }^{17}$ No Brasil, antes do ano de 1945, havia uma "esmagadora predominância da lenha no panorama energético brasileiro"(LEITE, 1997:87). Uma situação típica de regiões em que o meio natural era ainda um elemento de condicionamento do uso do território, do ponto de vista de seu uso produtivo. Dada a abundância de florestas utilizáveis, não havia ainda estímulo suficiente para a implantação de infra-estruturas energéticas diversificadas, que permitissem a geração e o transporte de energia em termos nacionais, integrados.
} 
b) atividades urbanas: uso da energia nos lares e na iluminação pública, entre outras necessidades das cidades em crescimento ${ }^{18}$.

Daí a importância de destacarmos a alteração no padrão de funcionamento do sistema elétrico brasileiro, e não só para o estado de São Paulo. A construção de grandes sistemas de engenharia para a produção de energia é um dado digno de nota: é o caso da Usina de Paulo Afonso, posta em funcionamento no ano de 1955. Vale destacar também o início das atividades da Usina Subterrânea de Cubatão (1955/56), Hidrelétrica de Peixotos, entre outras.

Um enorme acréscimo de sistemas técnicos é realizado no território, tanto na geração, quanto na transmissão da energia. É iniciado um processo de institucionalização (e estatização) do controle dos sistemas de engenharia, que merece ser destacado. São fundadas autarquias como a Companhia Hidrelétrica do São Francisco (CHESF) em 1948, as Centrais Hidrelétricas de Minas Gerais (CEMIG, em 1952) e Furnas (1957). A CEMIG, por exemplo, constrói no Estado mineiro (entre 1952 e 1956) as Usinas de Itutinga, Salto Grande, Tronqueiras e Cajuru; de 1957 a 1962, implantaria também a Usina de Três Marias, que seria “a quarta maior barragem de terra do mundo"(BIBLIEX, 1977:76).

Para coordenar as necessidades da demanda e da oferta de energia, o Governo Federal criar a Eletrobrás (1961), que cuidaria da integração dos esforços de geração de energia regionais. Como mostram Milton Santos e María Laura Silveira (2000:69), “a ocupação e a urbanização do território, o processo de industrialização, o aperfeiçoamento das técnicas de geração e transmissão e a

\footnotetext{
${ }^{18}$ No estado de São Paulo as cidades que mais se destacavam em termos de necessidades energéticas eram a própria capital, mas também os municípios do que viria a ser conhecido como o "grande $A B C$ ": principalmente as cidades de Santo André, São Bernardo do Campo e São Caetano do Sul. De 1954 para 1956, o consumo nestas cidades aumenta cerca de 51,7\% (SCHLESINGER, 1958:81). Também nas regiões mais distantes do cinturão da metrópole em formação o aumento deste consumo é expressivo: nas regiões de Jundiaí, Sorocaba, assim como no Vale do Paraíba, o consumo de energia aumenta em 31,9\%, para o mesmo lapso de dois anos (SCHLESINGER, op. cit.81). Conforme mencionado, a partir já do final dos anos 1940, os sistemas técnicos instalados no território não estavam mais conseguindo fazer face às necessidades das infra-estruturas demandantes de energia. Segundo estudo publicado pela Biblioteca do Exército (BIBLIEX, 1977), "de 1943 a 1953, a capacidade instalada aumenta $1,95 \%$ ao ano, a produção aumenta $2,56 \%$ ". Ocorria, portanto, "uma redução da reserva das instalações a níveis tais que comprometem a confiabilidade do sistema"(BIBLIEX, 1977:69), dizia-se.
} 
organização centralizada do setor em torno da Eletrobrás convergem para interligar boa parte dos sistemas isolados"19.

Não só o processo de integração é importante naquele momento, mas também (e talvez principalmente) as mudanças que a instalação de novos sistemas de engenharia produtores de energia provoca nos usos possíveis do território. Além de ser necessária a criação de um corpo de engenheiros e de trabalhadores que dessem conta do planejamento e da construção de tais sistemas, também sua instalação impulsiona ainda mais o processo de industrialização que ocorria. Como mostra o estudo da Biblioteca da Exército (BIBLIEX), para o caso da CEMIG,

"Com base na energia fornecida pela CEMIG desenvolvem-se a Companhia Siderúrgica Mannesmann (a partir de 1954), a USIMINAS (em 1962), e a produção de cimento, além de outras atividades industriais. No setor dos nãoferrosos torna-se possível a expansão da ALCAN, em Ouro Preto. (...) O desenvolvimento acelerado de Minas Gerais, com uma grande e diversificada eclosão industrial e um alargamento da sua fronteira agrícola, muito deverá a CEMIG"(BIBLIEX, 1977:76/77).

Esse conjunto novo de eventos (criação de sistemas de engenharia, institucionalização de autarquias públicas relacionadas) influenciaram sobremaneira a criação do Banco Nacional de Desenvolvimento Econômico (o BNDE). Como se tratava de sistemas de engenharia que demandam prazos de maturação dos investimentos bastante dilatados, somente com a criação de novos atores financeiros é que seria possível seu financiamento. Antes de falarmos da criação do BNDE, porém, faz-se necessário destacar o processo mais geral de intervenção do Estado nos demais eventos relacionados à industrialização do país.

\subsection{Conteúdos industriais e o "nacional-desenvolvimentismo": a ação estatal}

Dado o dinamismo do processo de transformação da base técnica do país instalado após a Segunda Guerra Mundial, convencionou-se dar o nome de "nacional-

\footnotetext{
${ }^{19}$ A criação, no ano de 1961, da autarquia federal Eletrobrás, se daria sob o signo de dois problemas cruciais: a) "o das perspectivas de sua autosuficiência econômico-financeira"(LEITE, 1997:129), que possibilitaria a modernização das infra-estruturas na velocidade e distribuição necessárias; e b) o da "integração física do sistema elétrico" (LEITE, 1997:129).
} 
desenvolvimentismo" a este período, ao menos na visão da economia política (TAVARES, 1978).

Constituído como principal articulador e executor das políticas de expansão do meio técnico-científico no território, o Estado passou a ser o mais importante agente deste processo modernizador. Não havia, na verdade, um parque industrial diversificado e "completo", para atender as novas demandas de consumo do território brasileiro. Não existia tampouco uma burguesia nacional dinâmica o suficiente para chamar a responsabilidade sobre essa industrialização. Daí a ação mais firme do Estado no planejamento e na condução das mudanças.

Além de uma política específica para o comércio exterior ${ }^{20}$, o Governo Federal implementa uma política de investimentos, com conseqüências diretas para a alteração dos conteúdos industriais e financeiros do território; neste período, são criadas as seguintes instituições públicas:

a) Usina de Volta Redonda (1946), que supriria de bens siderúrgicos de variados tipos todas as indústrias que passam a requerer este insumo em território brasileiro;

b) Centro Tecnológico da Aeronáutica (CTA) e o Conselho Nacional de Pesquisa (CNPq), ambos em 1951; formam-se estes institutos em função da preocupação estatal em promover iniciativas que viessem a incorporar o país de forma ativa no período técnico-científico que se gestava, financiando projetos e iniciativas nas Universidades que gerassem padrões tecnológicos menos dependentes de conhecimento gerado no exterior, e com maior adequação à realidade nacional; c) Banco Nacional de Desenvolvimento Econômico (1952), que, como veremos, se constituirá num sistema de ações especializado no projetamento de grandes investimentos, e financiará obras importantes para a remodelação dos grandes sistemas de engenharia aqui presentes;

\footnotetext{
20 Conforme nos mostra também Maria da Conceição Tavares (1978), essa política de comércio exterior permitiu, entre outras ações: a) uma discriminação controlada dos produtos importados (protegendo sensivelmente parte das indústrias nacionais em formação); b) uma liberação apenas da importação de bens de capital e produtos considerados estratégicos (que serviriam para completar os circuitos produtivos já instalados); e c) por último, mas não menos importante, dentro da política de comércio exterior foi executada uma hábil política cambial, que permitiu ao Estado reter boa parte dos lucros cambiais gerados com as importações/exportações, permitindo um financiamento não-inflacionário das atividades do Estado.
} 
d) Petrobrás (1953), que interferiria positivamente no suprimento de recursos energéticos do país, assim como posteriormente no suprimento de bens intermediários (derivados do petróleo) para uma gama enorme de indústrias.

Estes são os principais eventos, resultados de iniciativas governamentais, para fazer frente ao "desinteresse e incapacidade do capital privado (nacional e estrangeiro) em realizar investimentos em infra-estrutura e setores industriais básicos", lembranos Wilson Suzigan (1976:88).

Como é conhecido na literatura sobre a evolução das infra-estruturas do território brasileiro, a partir do ano de 1956 o Governo Federal implementa ainda uma série nova de políticas públicas que - dado o dinamismo que geram - nos permite falar numa inflexão do processo de industrialização do território. Durante os anos de 1956-1961, parece adequado afirmar que o chamado Plano de Metas passa a ser o eixo principal sobre o qual são possibilitados novos usos do território brasileiro. Neste "subperíodo" do Plano de Metas, podemos destacar ao menos três mudanças principais em relação aos seus usos industriais:

a) conforme já iniciado no subperíodo de 1945-55, é aumentada a presença do Estado na execução e no financiamento das estruturas produtivas nacionais;

b) concomitantemente, porém, são também incentivadas as entradas de capitais externos no território, fossem eles privados ou oficiais;

c) são instaladas no espaço brasileiro um conjunto de indústrias bastante dinâmicas a partir desta base, como por exemplo: a indústria automobilística, indústria naval, de material elétrico pesado, além de "outras indústrias mecânicas de bens de capital"(TAVARES, 1977:72). Expandemse várias indústrias já existentes, como a siderúrgica, a petrolífera, a metalurgia de não-ferrosos, a de celulose e papel e de química pesada, entre outras (TAVARES, op. cit.:72). 
A industrialização brasileira altera a divisão social e territorial do trabalho instalada. Os lugares da produção são cada vez mais dissociados dos lugares do consumo, o que leva a uma maior necessidade de integração material (física) do território. A quantidade de capitais necessários aos investimentos nestes sistemas de engenharia se avulta. As somas necessárias acabam por tornar pouco eficaz o sistema bancário (assim como o financeiro) existente, já que estes não tinham o dinamismo suficiente para suprir com capitais as novas demandas dos circuitos produtivos da nação.

Por que podemos dizer que essa nova constituição do espaço geográfico torna menos eficiente a atividade bancária existente até então? São ao menos duas novas necessidades de financiamento que nos permitem afirmar isto:

a) realização de investimentos nas grandes infra-estruturas de suporte em construção no território (rodovias, ferrovias, usinas geradoras de energia, equipamentos para a transmissão da energia etc.);

b) provimento de capitais para a dinamização das atividades industriais e comerciais que se instalavam com maior velocidade nos centros urbanos; tanto o financiamento do consumo de bens duráveis, como o provimento do chamado "capital de giro" das empresas tornam-se necessidades prementes.

Do ponto de vista dos investimentos nas grandes infra-estruturas, o processo é assumido (principalmente) pelo Governo Federal, que se vale de dois principais meios de obtenção de recursos: a) a utilização do sistema tributário em vigor, que permitia ao Estado (em suas esferas Federal, Estadual e Municipal) drenar recursos fiscais dos agentes econômicos e da renda gerada no território; e b) por meio da modernização do próprio sistema financeiro e bancário brasileiro, já que aquele herdado dos períodos anteriores não mais tinha funcionalidade para esta nova base técnica instalada ${ }^{21}$.

\footnotetext{
${ }^{21}$ Vale ressaltar que a nova base técnica que passa a funcionar no território brasileiro altera sensivelmente os tempos do território, principalmente aqueles tempos de maturação dos investimentos realizados. Essa "necessidade de se realizar um amplo programa de investimentos de infra-estutura"(MARTINS, 1985:85) é que balizaria os novos processos de planejamento do Governo Federal, por exemplo, que passaria a pensar no planejamento de seu território com prazos mais longos de tempo.
} 
Se antes as quantidades de técnicas e de capitais geografizados no território eram menores, também eram menores as necessidades de financiamento destes conteúdos. Mas o acréscimo em proporções cada vez mais vultosas de capitais fixos, em várias partes e em vários tipos de atividades produtivas, aumenta a necessidade de disponibilização de recursos financeiros da nação.

Não havia, na verdade, um sistema financeiro que permitisse grandes investimentos em sistemas de engenharia, já que estes, por definição, requerem prazos de maturação bastante longos (10, 20 ou até 30 anos, dependendo do tipo de atividade). Os atores financeiros instalados no território lidavam basicamente com a concessão de créditos em prazos mais curtos, geralmente para o financiamento da agricultura, ou para algumas atividades comerciais urbanas (GOLDSMITH, 1986).

Podemos dizer, portanto, que estes novos conteúdos do território (dos quais destacamos com algum detalhe aqueles ligados à geração de energia e à atividade industrial) é que impulsionarão a formação de um sistema financeiro e bancário nacional mais moderno, capaz de suprir com recursos de médio e - principalmente - de longo prazo, os novos sistemas de ações e de objetos que serão acrescentados ao território brasileiro no período. 


\section{CAPíTULO 3. As Necessidades de Financiamento do Meio Técnico-Científico e a Gênese do Sistema Financeiro Brasileiro}

\subsection{As técnicas bancárias e a criação da SUMOC}

Até o ano de 1945, duas principais características pautavam o funcionamento do sistema financeiro brasileiro: a) não era possível realizar um planejamento econômico de longo prazo, já que o sistema bancário - basicamente composto por instituições comerciais privadas - não conseguia drenar grandes quantidades de recursos através de sua rede de agências; e b) não havia também uma divisão bancária do trabalho consolidada; isto é , não existia uma autoridade monetária constituída, tampouco bancos especializados no fornecimento de créditos para infra-estruturas, indústrias, consumos urbanos etc. (PASSOS, 1973).

Nas décadas de 1950 e 1960, os agentes econômicos exigiam basicamente créditos para o "capital de giro" de empresas. Este capital de giro, por sua vez, era utilizado para a importação de certos produtos, realização e manutenção de estoques, ou ainda para o pagamento de funcionários. Normalmente os bancos comerciais trabalhavam com o horizonte máximo de 120 dias, no desconto de títulos comerciais. Esse tipo de demanda era passível de ser suprida pelo sistema bancário existente até então.

As dificuldades de se financiar em longo prazo no país tinham relação direta com a chamada "Lei da Usura" (RANGEL, 1963, 1983; 1980; BOUZAN, 1972; SILVA, 1981; TEIXEIRA, 2000). A "Lei da Usura" (Decreto-lei no. 22.626 de $07 / 04 / 1933$ ) proibia a cobrança de juros maiores que $12 \%$ ao ano pelo sistema bancário. Quando a inflação excedia a taxa de $12 \%$ ao ano, não era financeiramente interessante para os agentes econômicos (empresas, 
governo, famílias) que depositassem seus excedentes nos bancos. ${ }^{22} \mathrm{E}$ já que em vários anos do período que por ora analisamos as taxas de inflação eram maiores que as taxas de juros legalmente oferecidas (GOLDSMITH, 1986:219 e seguintes), o sistema bancário brasileiro não lograva captar grande parte da poupança gerada pelas atividades econômicas no território. Dada esta "anomalia estrutural", a poupança era canalizada fora dos mercados financeiros institucionais. A especulação com imóveis e compra de "divisas" (moeda estrangeira) "era o canal por onde mais freqüentemente fluía a poupança"(BULHÕES et alli, 1976:139). Era impossibilitado, destarte, que se constituísse um fluxo contínuo e vigoroso de depósitos que incrementasse a intermediação financeira de longo prazo no território.

Mas além da ausência de uma taxa de juros que favorecesse este amadurecimento da atividade bancária no país, inexistia ainda uma grande especialização entre as diferentes instituições financeiras nacionais. Esta falta de uma divisão bancária (e financeira) do trabalho se refletia na ausência de instituições financeiras voltadas para algumas carências específicas da nação. Dentre estas ausências, podemos lembrar: a) inexistiam Bancos de Desenvolvimento e/ou Investimento, para a construção de macrossistemas técnicos ${ }^{23}$ no território; e b) assim como não havia "sociedades financeiras" (para o financiamento da comercialização de bens de consumo duráveis, por exemplo).

Também a ação das instituições estatais de regulação dos agentes financeiros não era bem delimitada. Para entendermos melhor como esta divisão do trabalho era insuficiente, basta lembrarmos que o Banco do Brasil acumulava, no período em

\footnotetext{
${ }^{22} \mathrm{Na}$ visão do economista Ignácio Rangel, a Lei da Usura era um exemplo de "legislação irracional e arcaica", e que, durante toda as décadas de 1940 e 1950, obrigou o sistema bancário brasileiro a usar de vários métodos, sendo o principal deles "os juros pagos 'por baixo do balcão"” (RANGEL, [1963]1986]:75), que de certa forma conseguiam drenar parte das poupanças nacionais para o sistema bancário em consolidação. Na visão de Carlos Passos (1973), a Lei da Usura impedia a formação de um mercado de capitais de longo prazo, e constitú́a uma "anomalia estrutural" de nosso sistema financeiro. Também este autor identifica que somente com a cobrança de comissões, "emolumentos" e taxas de serviço "os bancos conseguiram fugir às exigências das autoridades monetárias concernentes às taxas de juros pagas pelos tomadores"(PASSOS, 1973:55).

${ }^{23} \mathrm{Na}$ acepção de Milton Santos (1996:142) os macrossistemas técnicos são aqueles "sistemas técnicos sem os quais outros sistemas técnicos não funcionariam. Os macro-sistemas técnicos promovem grandes trabalhos, (barragens, vias rápidas de transportes terrestres, aeroportos, telecomunicações, etc.), (...) e constituem o fundamento material das redes de poder".
} 
tela, algumas funções essenciais que, em tese, deveriam estar sob responsabilidade de uma "autoridade monetária", e não sob os auspícios de um banco comercial (mesmo que estatal). Dentre essas funções que o Banco do Brasil tinha sob sua responsabilidade, podemos destacar principalmente:

a) o papel de conceber e implementar as normas da atividade financeira no país;

b) a função de maior banco comercial do país (dada sua forte atuação na concessão de créditos agrícolas, mas também dos industriais); e

c) ainda a tarefa de banco do Tesouro da nação (PASSOS, 1973; COSTA NETO, $2001)^{24}$.

Este acúmulo de funções era prejudicial, por exemplo, à implementação de políticas monetárias eficientes, por exemplo. Na ausência de uma autoridade monetária constituída, não era possível controlar com rigor também a atividade creditícia, e assim era bastante dificultado, por exemplo, o controle da inflação ${ }^{25}$.

É nesse contexto que, no ano de 1945, é criada a Superintendência da Moeda e do Crédito (SUMOC), que viria a ser o "órgão controlador do sistema financeiro", ou simplesmente a autoridade monetária da nação. A partir da criação da SUMOC, começa a se estabelecer no Brasil o que Jean Labasse denominou de “regulamentação nacional”, com "especialização das tarefas" (LABASSE, 1974:68) do sistema bancário. Dentre as responsabilidades que a SUMOC centralizaria sob seu comando, podemos destacar: 1) a política cambial e a fiscalização do registro

\footnotetext{
${ }^{24}$ Mesmo após a reforma criada pela SUMOC o Banco do Brasil ainda manteria uma série de tarefas ligadas ao que se entenderia na época como tipicamente de uma Autoridade Monetária. Dentre estas funções, podemos destacar: a) o Banco do Brasil era ainda o "banco do governo", isto é, possuía forte relação dos valores depositados pelo tesouro federal com as ações do Banco; b) era também o controlador das operações do comércio exterior; c) executava as operações de câmbio em nome das empresas públicas, e do próprio Tesouro; d) era o organismo de execução das normas estabelecidas pela SUMOC.

${ }^{25}$ Resumidamente, esse mecanismo funcionaria da seguinte forma: a) os bancos comerciais têm sempre o interesse em expandir a quantidade de créditos no território, já que sua função última, é a intermediação financeira; b) a expansão dos créditos num determinado contexto produtivo de um território, pode estimular o aumento de preços praticados, já que a demanda por certos produtos aumentará, sem a contrapartida do lado da oferta; c) esta desigualdade entre oferta e procura de bens e serviços (engendrada pelo crescimento do crédito) é que pode levar um aumento de preços (inflação); d) a inflação, por sua vez, geralmente desestimulava a utilização do sistema bancário como fonte de entesouramento de poupanças, já que uma remuneração interessante sobre os excedentes era impedida pela Lei da Usura, como vimos (PASSOS, 1973:21).
} 
de capitais estrangeiros que adentrassem ou saíssem do território (GIAMBIAGI e ALÉM, 1999:79); 2) fixação das taxas de juros dos bancos comerciais, e determinação dos tetos e das taxas de redesconto do sistema financeiro ${ }^{26}$; 3 ) definição dos valores dos depósitos compulsórios dos bancos.

Com a SUMOC, "procurou-se institucionalizar o controle do sistema monetário"(SUZIGAN, 1976:87), tornando mais organizada a atuação dos bancos privados e públicos no território nacional. Se havia uma maior racionalidade dos objetos técnicos instalados, também uma maior racionalidade das possibilidades de financiamento desta base técnica fez-se necessária.

No que diz respeito aos novos conteúdos normativos que guiariam a atividade bancária a partir de então, a SUMOC define que o sistema estaria baseado em três tipos de instituições principais: os bancos comerciais privados nacionais, as Sociedades de Crédito, Financiamento e Investimento (também conhecidas como "financeiras"] e os bancos estrangeiros. Passemos então a uma análise mais pormenorizada desta nova divisão financeira do trabalho que é instalada no território brasileiro, a partir da ação da SUMOC.

\subsection{A nova divisão financeira do trabalho: bancos comerciais privados, "financeiras" e bancos estrangeiros}

A novidade em relação ao subperíodo anterior à criação da SUMOC no sistema financeiro brasileiro foi a criação das "financeiras". Mas a atuação dos bancos comerciais privados nacionais a partir de então também ganha outros matizes, principalmente no que diz respeito à topologia desta rede bancária. Vejamos melhor o que ocorrera.

\footnotetext{
${ }^{26} \mathrm{O}$ "redesconto" pode ser definido como uma espécie de empréstimo concedido pela Autoridade Monetária constituída, "por meio de uma operação na qual uma instituição bancária, para atender às suas necessidades de curto prazo para cobrir obrigações no momento, desconta, em outro banco, o título de crédito sobre o qual operou o desconto. Nesse processo, o banco que fez o empréstimo paga juros e comissões menores pelo fato de se tratar de uma operação interbancária; portanto, é paga uma taxa sobre o redesconto. A taxa de redesconto é um instrumento de política monetária"(BIDERMAN, 2006:334) da autoridade monetária de qualquer país.
} 
Uma das principais características da intermediação financeira no país eram os horizontes curtos nas operações de concessão de créditos realizadas, conforme frisado. Estes horizontes, por seu turno, dependiam da relação com os depósitos operados no sistema: se os depósitos eram de curto prazo, da mesma forma os créditos o seriam. E a maior porcentagem de "depósitos a longo prazo" realizada chegou a apenas 10,2\% dos totais (no ano de 1958); a grande maioria dos depósitos se dava no curto prazo: $52,7 \%$ dos totais em 1951 ; $67 \%$ dos totais em 1964 (GOLDSMITH, 1986:266).

Essa dificuldade de equacionar os depósitos/créditos em prazos mais longos, que acompanha o sistema financeiro durante todo o período da gênese do moderno sistema bancário, só será sanada a partir da Reforma Bancária de 1964/65, como veremos no capítulo 6 desta tese.

Mas se permanecia essa dificuldade em relação aos fluxos de recursos da rede bancária, a topologia da rede começa a ser estendida. No período em questão, há um grande aumento do número de agências bancárias no país. De 4.038 agências existentes em 1951, o território passa a contar com 5.135 em 1959, para chegar a 6.826 agências em 1964. Um crescimento de 69\% destes fixos geográficos no período 1951-1964.

As causas dessa diástole das agências bancárias no território foram duas, basicamente:

a) a expansão do meio técnico-científico no território: a formação de uma rede de cidades mais densa no Brasil vai gerar uma demanda maior das atividades de intermediação financeira, pressionando os bancos para a concessão de créditos novos e, portanto, para a abertura de agências; e

b) a busca de depósitos nas áreas econômicas dinâmicas. para garantir a existência de recursos para a concessão de créditos, "tornava-se imperativo para o sucesso dos bancos - e talvez à sua sobrevivência - ampliar a capacidade de captação; ou 
seja, ampliar a sua rede de agências de forma a ir buscar os depósitos onde quer que eles pudessem ser encontrados"(BOUZAN, 1972:42).

Com relação a este segundo ponto, também Carlos Passos (1973:57) assevera que nesse período houve uma verdadeira "caça aos depósitos", "porque os bancos, pensando em desenvolver os depósitos dos clientes, começaram a criar novas filiais e até mesmo a procurar recursos nas residências dos depositantes".

Esse aumento do número de agências, porém, não significou uma desconcentração grande dos depósitos e dos empréstimos realizados no território. Como todas as demais atividades econômicas, também o sistema de ações financeiro buscava se instalar nas áreas mais dinâmicas do espaço nacional, onde as possibilidades de financiamento e as taxas de retorno para os capitais negociados eram sempre mais atraentes (COSTA, 1988).

A tabela a seguir nos dá uma idéia mais aproximada do fenômeno da intermediação financeira realizada no território, e contempla os depósitos e os empréstimos realizados pelo sistema bancário nacional nos anos de 1945 e 1965. Estes dois fenômenos definem o que Jean Labasse (1974:167 e ss.) denominou de "fisionomia financeira das regiões". Essa fisionomia depende tanto dos empréstimos realizados numa região (e são considerados como "passivos regionais"), como dos depósitos realizados (por sua vez, os "ativos regionais") (LABASSE, op. cit.:167-168). 
Tabela 3: Brasil: Distribuição dos Ativos e dos Passivos Regionais (em \%) (1945-1965)

\begin{tabular}{|c|c|c|c|c|}
\hline & \multicolumn{2}{|c|}{ Depósitos } & \multicolumn{2}{|c|}{ Empréstimos } \\
\hline & 1945 & 1965 & 1945 & 1965 \\
\hline Amazônia & 1,5 & 0,9 & 0,8 & 0,8 \\
\hline Nordeste & 7,0 & 5,9 & 9,0 & 6,3 \\
\hline Pernambuco & 2,8 & 1,5 & 3,0 & 1,8 \\
\hline Bahia & 1,9 & 1,5 & 2,2 & 1,5 \\
\hline Sudeste & 73,4 & 36,9 & 69,1 & 24,3 \\
\hline Rio de Janeiro ${ }^{27}$ & 40,0 & 6,1 & 40,7 & 7,8 \\
\hline São Paulo & 32,8 & 20,4 & 27,7 & 16,1 \\
\hline Sul & 8,1 & 6,3 & 7,6 & 7,0 \\
\hline $\begin{array}{l}\text { Rio Grande do } \\
\text { Sul }\end{array}$ & 5,2 & 2,4 & 5,7 & 3,5 \\
\hline Centro-Oeste & 10,0 & 49,9 & 13,4 & 61,6 \\
\hline Minas Gerais ${ }^{28}$ & 9,3 & 3,3 & 11,5 & 3,4 \\
\hline Brasília & - & 45,9 & - & 57,2 \\
\hline Brasil (totais) & 100 & 100 & 100 & 100 \\
\hline
\end{tabular}

Fonte: Anuário Estatístico do Banco Central; adaptado de Goldsmith (1986:268)

A distribuição dos empréstimos e depósitos realizados no território brasileiro à época nos permite, em primeiro lugar, observar como foi alterada a densidade financeira das regiões. Em primeiro lugar, vale destacar a diminuição expressiva dos ativos e passivos existentes no Estado do Rio de Janeiro. De um controle de cerca de $40 \%$ (tanto dos depósitos quanto dos empréstimos) no ano de 1945, os atores financeiros do Estado passam a manipular apenas cerca de $6 \%$ e $7 \%$ dos totais, respectivamente.

Esta mudança enorme foi em grande parte provocada pela transferência da capital federal para o Centro-Oeste do país, com a construção da cidade de Brasília. Junto do próprio controle político do Executivo Federal, também as principais autarquias federais são para lá deslocadas, assim como as sedes do Banco do Brasil e da SUMOC.

27 Foram somadas as porcentagens do Estado da Guanabara com as do Rio de Janeiro para a confecção da tabela; até o ano de 1956, quando a capital federal é transferida para Brasília, o distrito federal se localizava no Estado da Guanabara.

${ }^{28}$ O Estado de Minas Gerais está considerado aqui dentro da Região Centro-Oeste, segundo a proposta de Raymond Goldsmith (1986). 
Ligado a esse fenômeno, portanto, vemos também um crescimento exponencial das densidades financeiras da Região Centro-Oeste: no caso dos depósitos, de um total de $10 \%$ que controlava em 1945 , passa a gerenciar quase a metade dos totais nacionais em 1964 (49,9\%); no que tange aos empréstimos, de cerca dos 13,4\% concedidos, passa a se responsabilizar por nada menos que $61,6 \%$.

Se os fluxos de depósitos e empréstimos se comportaram desta maneira no período, o que podemos dizer da distribuição geográfica das instituições financeiras? Qual era a topologia dos bancos comerciais privados na época? No que diz respeito a essa distribuição, podemos afirmar em primeiro lugar que os bancos eram já bastante concentrados, em parcelas selecionadas do território brasileiro. Assim como os passivos e ativos regionais, a rede bancária privada estava situada sobremaneira nos Estados de São Paulo, Minas Gerais e na Guanabara, como mostra a tabela a seguir:

Tabela 4: Brasil: Distribuição dos Bancos Privados no Território Nacional (1963)

\begin{tabular}{|l|c|c|}
\hline Estados & Número de bancos & $\%$ \\
\hline São Paulo & 40 & 32,5 \\
\hline Guanabara & 27 & 22,0 \\
\hline Minas Gerais & 13 & 10,5 \\
\hline Demais estados e Distrito Federal & 43 & 35,0 \\
\hline TOTAL & 123 & 100,0 \\
\hline
\end{tabular}

Fonte: PASSOS, Carlos de Faro [1973:32]

Cerca de $65 \%$ dos bancos comerciais privados se encontravam nos três estados acima mencionados, restando às outras partes do território 35\% das instituições deste tipo. O Estado de São Paulo (dado o dinamismo de sua rede de cidades, assim como de sua capital) aumenta sua importância no comando das finanças do país, e a partir deste período passaria a polarizar cada vez mais os serviços financeiros do território, como notara também Roberto Lobato Corrêa (1989; $1989,2006)^{29}$. Nesse período é possível já falarmos na formação da Região

${ }^{29}$ Outros dados também ajudam a entender esta desigual densidade financeira do País: em 1963, enquanto a média de habitantes por agência no Brasil era de 13.000, nos Estados da Região Norte esta média era de 39.000 habitantes por agência, enquanto no Nordeste esta cifra era de 72.000 habitantes/agência. Já nos Estados da Região Sul e Sudeste cada banco “atenderia" em média 7.700 habitantes (PASSOS, 1973:32). 
Concentrada no território brasileiro, formada pela presença de um meio técnico mais dinâmico e contíguo nas Regiões Sul e Sudeste do território brasileiro (SANTOS e RIBEIRO, 1979; SANTOS, 1993; SANTOS e SILVEIRA, 2001) ${ }^{30}$.

Este é um quadro do funcionamento de parte das principais instituições de concessão de crédito no Brasil, isto é, os bancos privados nacionais. Mas a mudança na divisão do trabalho implementada pela SUMOC criou também outro tipo de instituição financeira, dadas as novas necessidades de financiamento das atividades econômicas aqui desenvolvidas. Para tentar fazer frente às demandas de créditos comerciais em prazos mais estendidos, é que são estabelecidas as Sociedades de Financiamento e Investimento, conhecidas também como "financeiras". Vejamos como funcionava este novo ator da divisão financeira do trabalho à época.

Para Natermes Teixeira (2000), as "financeiras" forneceriam basicamente créditos no médio prazo, tanto para o capital de giro de firmas comerciais e industriais, quanto para o financiamento do consumo de produtos. Os bancos comerciais, como vimos, não tinham condições de suprir estes tipos de créditos, já que não contavam com quantidades suficientes de depósitos a prazo em seus cofres.

As Sociedades de Crédito, Financiamento e Investimento "obtinham seus recursos através da colocação de títulos financeiros junto ao público, utilizando-os, após, em operações de crédito, financiamento e investimento", como destaca Carlos Passos (1973:34). O investidor participante deste sistema não poderia resgatar sua aplicação num prazo menor que doze meses (esse era o tempo mínimo exigido, a partir de um aviso prévio por parte do investidor), e o prazo máximo do financiamento não poderia ultrapassar os seis meses. Além do crédito ao consumo, as financeiras poderiam operar também o chamado "aceite cambial", que "se

\footnotetext{
30 Segundo a definição de Milton Santos (1993:40), a Região Concentrada é definida como "uma área contígua onde uma divisão do trabalho mais intensa que no resto do País garante a presença conjunta das variáveis mais modernas - uma modernização generalizada - ao passo que no resto do País a modernização é seletiva, mesmo naquelas manchas ou pontos cada vez mais extensos e numerosos, onde estão presentes grandes capitais, tecnologias de ponta e modelos elaborados de organização. A Região Concentrada coincide com a área contínua de manifestação do meio técnico-científico $(. .)$.$" .$
} 
realizava quando uma empresa necessitada de capital de giro sacava sobre a sociedade de crédito uma "letra de câmbio ao portador'"(PASSOS, op. cit::35).

Os dados encontrados pela pesquisa mostram um expressivo crescimento do número de "Sociedades Financeiras" autorizadas a funcionar no período em tela: de 100 "financeiras" existentes em 1961, o território passa a abrigar nada menos que 146, no ano de 1964 (PASSOS, 1973:35).

Afora a presença dos bancos comerciais nacionais e as "financeiras", a organização do sistema bancário brasileiro era composta ainda pelos bancos estrangeiros que atuavam no território. Como era essa relação dos bancos estrangeiros com os demais atores financeiros? Que lugar ocupavam eles na divisão bancária do trabalho?

Conforme vimos no início da tese, os bancos comerciais estrangeiros tiveram uma importância oscilante na evolução do sistema bancário brasileiro. Se na gênese da rede bancária tiveram papel destacado, a partir do final da década de 1920 perdem importância, como vimos no capítulo 1. No período do pós-Segunda Guerra Mundial, os bancos estrangeiros continuam sendo pouco expressivos no sistema bancário nacional. Segundo Carlos de Faro Passos (1973:34),

"Quanto aos bancos estrangeiros, observou-se que entre 1945 e 1965 não ocuparam um papel importante no sistema bancário brasileiro. Seus depósitos, no fim de 1949 , representavam $7,8 \%$ do total no país, e 11 anos após atingiram 3,4\% deste conjunto"31.

Vários são os motivos que nos ajudam a explicar essa menor importância dos bancos estrangeiros na intermediação financeira no Brasil. Em primeiro lugar, vale destacar que o arcabouço normativo continuava sendo inibidor da ação de bancos estrangeiros no território, como ocorrera desde as décadas de 1920 e 1930.

31 Já no período da Segunda Guerra Mundial há diminuição sensível da ação dos bancos estrangeiros no território: dos 80 que existiam em 1940, restariam apenas 38 em 1944. Neste mesmo período, Fernando Costa (1988:234) nos lembra que o número de bancos nacionais passa de 354 (em 1940) para 663 (em 1944). 
Mas não só em função das normas é que essa importância era menor. Podemos destacar ainda três outros elementos explicativos para a situação destes bancos no País:

a) eles não efetuavam empréstimos para os circuitos agrícolas do território, atividade que poderia fazer aumentar sua participação como agente financeiro na economia nacional;

b) como atuavam basicamente no comércio exterior, tanto o processo de substituição de importações (que privilegiava mais o mercado interno do país), como o aumento da concorrência do Banco do Brasil nestes financiamentos, passa a fazer com que os bancos estrangeiros percam terreno, na disputa pelos fluxos financeiros nacionais (PASSOS, 1973:34);

c) como os bancos estrangeiros localizavam-se basicamente no litoral (dada essa grande ligação dos mesmos com o comércio exterior), a interiorização do desenvolvimento iniciada nesta época não auxilia suas atividades; ao contrário, "o fortalecimento do mercado interno, em desfavor das trocas com o exterior, foi mais favorável aos bancos nacionais"'[COSTA, 1988:236)

\subsection{A SUMOC e o controle da topologia bancária}

A topologia das instituições de concessão de crédito no Brasil era basicamente fundada em agências bancárias. Em países como a França (ver LABASSE, 1955), por exemplo, operações de crédito eram realizadas também por fixos geográficos menos complexos do ponto de vista operacional, como os "guichets".

Ao final da Segunda Guerra Mundial, há um crescimento acentuado do número de agências bancárias no País, como mostra a tabela abaixo:

Tabela 5: Brasil: Evolução do Número de Agências e Matrizes de bancos (1946-1965)

\begin{tabular}{|l|r|r|r|}
\hline & $\mathbf{1 9 4 6}$ & \multicolumn{1}{|c|}{$\mathbf{1 9 5 6}$} & \multicolumn{1}{c|}{1964} \\
\hline Total de Agências & 2.079 & 3.897 & 6.550 \\
\hline No. de Matrizes & 473 & 360 & 328 \\
\hline Relação Agências/Matrizes & 4,4 & 10,8 & 19,9 \\
\hline
\end{tabular}

Fonte: Elaboração própria a partir do trabalho de Hélio DE CASTRO (1981:90) 
Num lapso de dez anos, entre 1946 e 1956, o número de agências praticamente dobra, com um crescimento de cerca de 87\%. Entre 1956 e 1964, o número de agências aumenta cerca de $68 \%$, triplicando o número de fixos geográficos deste tipo existentes no território ${ }^{32}$. Mas outro dado ainda chama a atenção na tabela acima: o número de bancos do sistema financeiro diminui. O que teria ocorrido?

Ao contrário do que sucedera no período anterior à criação da SUMOC, passa a ser uma política explícita do Governo Federal a busca de uma diminuição do número de instituições bancárias. Autores como Ary Bouzan (1972) e Helio de Castro (1981) asseveram que um processo de fusões/aquisições entre instituições bancárias era necessário, para aumentar as "economias de escala" do sistema. Ou ainda nas palavras de Martus Tavares e Nelson Carvalheiro (1985:30/31), "o crescimento desordenando do número de agências fez que se elevassem os custos operacionais dos bancos", e daí a necessidade de uma política para o controle do número de instituições agindo no território brasileiro. A relação entre o número de matrizes/número de agências que era de cerca de 2,7 (em 1944, como vimos), passa a ser de 19,9 em 1964.

Além do crescimento da rede bancária brasileira ter levado o Governo Federal a editar o Decreto Lei no. 6541 (de 29.05.1944), que visava corrigir "o agrupamento dos bancos no que se refere ao estabelecimento de filiais ou agências"(TAVARES e CARVALHEIRO, 1985:149), é com a Instrução no. 37 (de 20 de junho de 1951) que a SUMOC vai imprimir uma distribuição mais controlada da rede de agências bancárias no país. Isto é, além da Autoridade Monetária fomentar um processo de concentração bancária, interfere também no processo de distribuição das agências no território ${ }^{33}$.

\footnotetext{
32 Vale frisar que o Banco do Brasil era nessa época o único ator com "amplo sistema de agências", constituindo-se no "único banco operando em bases nacionais"(GOLDSMITH, 1986:265). Como mostra Helio de Castro (1981:90), em 1946 o Banco do Brasil possuía já 267 agências espalhadas pelo País; em 1956 esse número sobe para 362, para chegar no ano de 1964 com 576 fixos geográficos no território.

33 Para Rui Aguiar Leme, havia já no início dos anos 1960 um "número excessivo de agências no país"(LEME, 1968:299). Assim como Carlos Passos (1973), o autor identifica no processo inflacionário a causa desta expansão do número de agências no período; ver ainda Rui Leme (1985).
} 
No que diz respeito à distribuição das agências pelo território, era do entendimento da SUMOC que o avanço destes fixos geográficos ${ }^{34}$ estava se dando de maneira muito concentrada em certos pontos e áreas do espaço nacional. Isto, por um lado, prejudicava as regiões que não eram assistidas pelos serviços bancários; ao mesmo tempo, saturava praças em que os serviços eram oferecidos de forma sobreposta. A distribuição dos passivos e dos ativos regionais, como vimos na tabela 3 , pode ser considerada uma evidência concreta dessa desigualdade, assim como a tabela 4, que mostra a concentração dos bancos nos Estado de São Paulo e Guanabara, no início dos anos 1960.

Deste entendimento, foram criados critérios para a regionalização da instalação das agências, critérios consubstanciados na Instrução no. 37 (de 20 de junho de 1951), que teria como preocupação a instalação de uma quantidade ideal de agências para cada região. Assim, o território seria dividido em basicamente três categorias (no que diz respeito à instalação de novas agências):

1) "zonas de captação de fundos": seriam aquelas áreas "desenvolvidas", em que as atividades econômicas "já estabilizadas" não conseguissem "absorver os recursos ali mobilizáveis"; assim, "quando o montante de empréstimos fosse igual ou superior à metade do montante de depósitos, não seriam concedidas autorização (sic) para abertura de novas agências" (TAVARES e CARVALHEIRO, 1985:152);

2) "zonas florescentes": seriam constituídas pelas áreas em que "a produção e o comércio tivessem um valor tal que se pudesse considerá-las completamente desenvolvidas e potencialmente ricas" (TAVARES e CARVALHEIRO, op. cit:152); nestas parcelas do território, "somente não se instalariam novas filiais quando o total de empréstimos atingisse o equivalente a $90 \%$ dos depósitos lá existentes" (idem: 152); e finalmente,

\footnotetext{
34 Os "fixos geográficos" comporiam, junto com os "fluxos geográficos", um par dialético passível de ser utilizado para o entendimento do funcionamento do espaço geográfico. Segundo a proposta de Milton Santos, "o espaço é, também e sempre, formado de fixos e fluxos. Nós temos coisas fixas, fluxos que se originam dessas coisas fixas, fluxos que chegam a essas coisas fixas. (...) Os fixos são os próprios instrumentos de trabalho e as forças produtivas em geral, incluindo a massa dos homens. (...) Os fluxos são o movimento, a circulação e assim eles nos dão, também, a explicação dos fenômenos da distribuição e do consumo"(SANTOS, 1988:77). Neste sentido, as agências bancárias são entendidas aqui como o principal fixo geográfico que compõe a topologia bancária brasileira (ao menos nesse período).
} 
3) "zonas novas": eram consideradas "zonas novas" as parcelas do território em que a exploração econômica houvesse se dado "recentemente", com tempos de maturação de investimentos maiores do que os recursos captáveis localmente pudessem suprir; daí que, nestas zonas, "seriam admitidas instalações de novas agências até o ponto em que os empréstimos atingissem volume equivalente a $150 \%$ dos depósitos totais existentes na localidade" (ibidem:152).

A SUMOC passa, assim, a controlar a distribuição das agências bancárias no Brasil, através das sucessivas regulamentações que impõe aos atores financeiros ${ }^{35}$. Ao que indica a bibliografia analisada sobre o assunto (DE CASTRO, 1981; TAVARES e CARVALHEIRO, 1985), houve relativo sucesso destas políticas de distribuição das agências bancárias no território para o período ${ }^{36}$.

Se a SUMOC consegue racionalizar a divisão financeira do trabalho no território brasileiro, restava ainda criar novos atores que financiassem a construção dos sistemas de engenharia, cuja escala das operações não podia ser suprida pelos bancos privados que atuavam no país à época. Além desta necessidade de créditos para os macrossistemas técnicos, também passa a ser preocupação das autoridades centrais a possibilidade de desconcentração da industrialização no território. Vislumbra-se ainda o aproveitamento das especificidades regionais do território, principalmente quando esse aproveitamento não era suficientemente dinâmico para gerar o interesse dos bancos privados nacionais. Daí surgirem, neste período de nossa história territorial, os Bancos Federais regionais.

\footnotetext{
35 Entre exemplos de alteração dos conteúdos normativos do território diretamente relacionados com sua topologia bancária estão: a) Instrução no. 95 , de 15/07/1954; b) Instrução no. 134, de 05/07/1956; c) Instrução no. 188, de 11/11/1959 (TAVARES e CARVALHEIRO, 1985).

36 Ainda que tímida, houve diminuição relativa da quantidade de agências na região sudeste do país, como mostra o autor: "Ao longo desses 20 anos também variou a distribuição regional de agências e matrizes. No ano inicial (1946), mais de 77\% das matrizes e 69\% das agências encontravam-se na região Sudeste. Em 1966 estas proporções haviam baixado respectivamente para 67\% e 62\%"(DE CASTRO, 1981:88).
} 


\subsection{A criação dos bancos federais regionais}

Como frisamos no capítulo 2, uma das características marcantes da entrada do país no período técnico-científico está ligada ao aumento da participação de instituições estatais na organização da vida da nação. Tanto na ação direta, com a criação de empresas estatais, holdings federais, quanto pela intervenção indireta, isto é, pela criação de instituições normativas, reguladoras destas empresas supracitadas.

A necessidade de atingir "atividades ou setores essenciais ao desenvolvimento", isto é, interesses estratégicos, ligados à "segurança nacional" (SUZIGAN, 1976:86/87) era o principal argumento da época para a criação de novos atores financeiros no território. Neste espírito, foram instaladas várias empresas estatais, não só ligadas às finanças, mas também em importantes atividades como as da mineração, indústria de transformação, transportes, entre outras ${ }^{37}$.

Nesta fase em que se esboçava o desenvolvimento do meio técnico-científico no País, podemos destacar dois exemplos concretos da maior intervenção do Estado na organização das finanças nacionais: a criação do Banco de Crédito da Borracha (1942) assim como da Caixa de Crédito Cooperativo $(1943)^{38}$.

\footnotetext{
${ }^{37}$ Na Mineração, vale destacar: criação da Cia. Vale do Rio Doce (1942) e encampação da Cia. Brasileira de Mineração e Siderurgia S/A e da Itabira Mineração S/A, no mesmo ano; na Indústria da Transformação, podemos lembrar a Criação da Companhia Siderúrgica Nacional (1941); criação da Cia. de Aços Especiais Itabira (1944); Cia. Nacional de Álcalis (1943); com relação às instituições ligadas aos Transportes, temos também a criação do Departamento Nacional de Estradas de Ferro (1941); Serviço de Navegação do Amazonas e Administração do Porto do Pará (1940); Serviço de Navegação da Bacia do Prata (1942); Cia. Nacional de Navegação Costeira (1942); ver Suzigan (1976).

${ }^{38}$ Com relação à criação do Banco de Crédito da Borracha, é importante lembrar que a Segunda Grande Guerra foi um período de aproximação do Brasil com o capitalismo norte-americano. Tanto em função de questões geoestratégicas (a posição privilegiada do Estado do Rio Grande do Norte para a aeronavegação no Atlântico Sul, por exemplo), quanto pela importância do Brasil no concerto das nações sul-americanas, há um interesse desenvolvido pelos EUA em estreitar as relações entre os dois países. A criação do Banco de Crédito da Borracha (BCB) é um evento diretamente relacionado a este contexto histórico, e acaba por revigorar os circuitos produtivos da borracha na região amazônica, ao menos até o findar da Guerra. (COSTA NETO, 2001)
} 
O que importa destacar também é que neste período inicia-se um processo de preocupação mais sistemática - por parte do Estado brasileiro - em relação às chamadas "regiões-problema" do País: são criadas instituições voltadas ao desenvolvimento tanto da Região Amazônica, quanto do Nordeste brasileiro. A formação do mercado interno, portanto, acaba por aumentar também a tomada de consciência acerca das desigualdades regionais que se gestavam.

A Região Amazônica, como mostra Roberto Santos (2002), devia seu desenvolvimento em grande parte à chamada "economia de aviamento", praticada como vimos - desde ao menos o final do século XIX. Esta forma de organização do beneficiamento e comercialização da borracha tinha como pilar as grandes casas exportadoras do produto, detentoras de capitais suficientes para financiar o uso daquela porção do espaço a seu favor. Assim, distribuíam créditos aos intermediários (ligação das casas exportadoras com os seringueiros), e forneciam parte dos objetos técnicos (ferramentário) e meios de subsistência para estes agentes.

Os intermediários, por sua vez, manipulavam tanto os créditos quanto os demais insumos que seriam utilizados para os seringueiros. Os seringueiros - o elo mais fraco do circuito espacial da produção - não conseguiam jamais se livrar dessa dependência do grande capital comercial, já que este, através da concessão de créditos difíceis de serem saldados, acabava por drenar todo o excedente produzido localmente, impossibilitando o desenvolvimento territorializado (ou horizontalizado) da região.

Modernizar o sistema de concessão de crédito na Amazônia era o primeiro fator relacionado à criação de uma instituição financeira regional, voltada para os conteúdos específicos desta parcela importante do território nacional. Mas também um fator externo acabaria por ser uma das causas da criação do Banco de Crédito da Borracha. Desde o início da Segunda Guerra Mundial, a borracha começa a escassear no mercado mundial, principalmente para o mercado consumidor norte- 
americano; daí a necessidade de estabelecer na Região Amazônica um Banco que viesse a dinamizar a produção local, para atender à demanda dos Estados Unidos. Como mostra Roberto R. Corrêa (2002), a criação de novas infra-estruturas no Brasil nessa época derivavam de acordos firmados entre os Governos brasileiro e dos Estados Unidos. Principalmente a partir de 1942, são realizadas várias combinações,

\begin{abstract}
"destinadas a criar instituições e organizações estatais e paraestatais, nacionais, estrangeiras e mistas, de caráter logístico e operacional, direcionadas para atuação nas áreas de abastecimento, transporte, gestão de mão-de-obra, financiamento bancário e comercialização de borracha. Um verdadeiro aparato institucional e organizacional que visava, em última instância, dar previsibilidade às ações havidas como indispensáveis para o abastecimento dos exércitos aliados, em um produto estratégico - a borracha - em falta no mercado internacional desde a ocupação, pelos japoneses, das plantações do Oriente"'(CORRÊA, 2002:348).
\end{abstract}

Assim, através do Decreto Lei No. 4.451 de 9 de julho de 1942 é criado o Banco de Crédito da Borracha S.A. Além de concatenar a produção regional para as necessidades do mercado externo da borracha, a criação do Banco de Crédito da Borracha $(\mathrm{BCB})$ foi também um "duro, mas não derradeiro, golpe nas oligarquias regionais - habituadas ao lucro fácil e rápido, proporcionado pelo velho sistema de aviamento"(CORRÊA, 2002:351).

A interferência do Banco de Crédito da Borracha na organização da região iria aumentar paulatinamente, com as sucessivas medidas do Governo Federal para utilizar a instituição como um dos principais promotores do desenvolvimento regional da Amazônia. Data da Constituição promulgada em 1946, neste sentido, o artigo 199, que estabelece um "Programa de Desenvolvimento" para a Região, "a ser financiado por 3\% do total de receitas dos impostos federais"[COSTA NETO, 2001:86), durante um período de 20 anos.

Mas não só na Região Norte do país é que vemos aumentar a preocupação do Estado brasileiro com a organização financeira do território nacional. No Nordeste, também é institucionalizada essa preocupação com o desenvolvimento 
regional, e o artigo 198 da Constituição de 1946 é uma manifestação desta necessidade de mudanças. Este artigo determinava "a destinação de valor nunca inferior a $3 \%$ das receitas tributárias da União e dos estados da região para obras e serviços, assistência econômica e social"(COSTA NETO, op. cit::86) para a Região.

Esses eventos, portanto, alteram os conteúdos financeiros do território brasileiro, já que criam importantes instituições bancárias que visavam basicamente a drenagem e irrigação de recursos para o desenvolvimento das regiões em questão. Detenhamo-nos um pouco mais na questão nordestina.

O processo de drenagem de recursos para o financiamento do desenvolvimento do Nordeste teria, num primeiro momento, uma proposta de resolução "fiscal": ao menos 3\% das receitas da União - independentemente de qual o imposto que desse origem à receita - teriam que obrigatoriamente ser re-territorializadas na região. Restava criar a infra-estrutura bancária que viesse a tornar a "irrigação" de recursos possível, e mais eficaz.

Segundo o economista Yttrio Costa Neto (2004), a princípio, foi utilizada a própria rede de agências do Banco do Brasil como instrumento de intermediação financeira, para os projetos de desenvolvimento do Nordeste. O Banco do Brasil era, nesta época, o único de dimensões verdadeiramente nacionais, como nos chama a atenção Raymond Goldsmith (1986).

Como havia já na Região esta rede de agências instaladas, faltava realizar uma melhor distribuição dos recursos entre as agências, em prol de ações econômicas eminentemente locais e/ou regionais. Assim, definidos os recursos através da Constituição de 1946, os canais de financiamento arrecadados pela União seriam basicamente repassados na Região (na forma de empréstimos) pelo Banco do Brasil, da seguinte maneira: 
"tais empréstimos deveriam ser canalizados para o financiamento de até $50 \%$ das despesas para construção de açudes em cooperação com o governo federal e com o governo estadual; financiamento até o limite das despesas orçadas para a construção de pequenos açudes e barragens submersas, às expensas do interessado; aquisição ou construção de silos e construção de armazéns nas fazendas; obras de irrigação, perfuração e instalação de poços profundos; aquisição ou reforma de equipamentos e de máquinas agrícolas ou industriais e aquisição de animais de trabalho; produção de energia elétrica; plantação técnica e intensiva de árvores xerófilas de reconhecido valor econômico; financiamento de serviços e obras de saneamento e desobstrução e limpeza de rios e canais; e financiamento de safras agrícolas, em geral, por intermédio de cooperativas agrícolas"(COSTA NETO, 2001:87).

Parecia haver clara concordância de que assim como nas regiões mais dinâmicas do país, era necessário criar bancos atuantes, que permitissem o fortalecimento das ações econômicas regionais, e que melhorassem assim a posição das Regiões Norte e Nordeste na divisão territorial do trabalho em desenvolvimento ${ }^{39}$.

Ainda no que diz respeito ao Nordeste, o surgimento dos Bancos Federais Regionais é também uma resposta à incapacidade da rede bancária pública ali presente (basicamente composta por agências do Banco do Brasil) de atingir os objetivos colimados na nova Constituição. Segundo o entendimento dos especialistas do Governo Federal, vários processos de financiamento precisariam ser implementados por uma instituição menos centralizada. O Banco do Brasil, por ter uma estrutura de comando pouco desconcentrada, não poderia ser esta instituição. Daí a proposta da criação de um banco federal na região, justamente porque seria ele mais próximo (física e organizacionalmente) das necessidades e das realidades peculiares desta "região-problema" do país.

Há ainda duas características básicas do processo de criação dos Bancos Federais Regionais que nos ajudam a esclarecer melhor essa necessidade de horizontalização do sistema que se montava:

1) sendo o circuito financeiro federal orientado para um programa de desenvolvimento eminentemente regional, o banco a ser criado deveria ser

\footnotetext{
39 Para uma análise da evolução da "divisão regional do trabalho" no Brasil, e suas conseqüências para a Região Nordeste, ver OLIVEIRA $[1977,1987)$.
} 
"formado na mentalidade dos problemas de região, vinculando a uma experiência específica sua direção e seus quadros" (COSTA NETO, 2001:87);

2) dadas as possibilidades limitadas do Banco do Brasil em assumir a empreitada, era necessário criar um banco ao mesmo tempo "centralizado", mas cujo controle sobre as decisões estivesse, porém, próximo à região [COSTA NETO, 2001:88].

Assim é que surge, no ano de 1952 (e entra em funcionamento efetivamente em 1954), o Banco do Nordeste do Brasil (BNB). A princípio, seus recursos também teriam uma origem eminentemente fiscal: entre $60 \%$ a $80 \%$ do dinheiro viria do direcionamento dos capitais previstos pela Lei 1.004 de 1949 (já referida). Além destes montantes, seriam ainda fontes de financiamento do banco: 1) os depósitos do público; 2) os lucros obtidos com as operações de financiamento do banco; e 3) a emissão de títulos do banco.

Estas são as linhas gerais pelas quais são criadas importantes instituições financeiras federais, que permanecem até hoje em funcionamento no território, e que têm como função precípua a manutenção das densidades financeiras das regiões com menor dinamismo econômico do país. A existência de atores públicos em regiões menos desenvolvidas de qualquer território contribui para evitar a concentração dos capitais nas cidades e nas regiões mais dinâmicas destes mesmos espaços.

Além dos Bancos Regionais, surge também no período outra importante instituição financeira federal, mais voltada para o financiamento de macrossistemas técnicos no território. Este Banco, como mencionamos, é o Banco Nacional de Desenvolvimento Econômico (BNDE), que cumpriu papel essencial na expansão do meio técnico-científico no país, como veremos a seguir. 


\subsection{O BNDE e o financiamento dos circuitos produtivos estratégicos}

O Banco Nacional do Desenvolvimento Econômico é criado no ano de 1952, e seu desenvolvimento foi em parte influenciado pela constituição da chamada "Comissão Mista Brasil-Estados Unidos", que previra (já em 1948) a "necessidade de se realizar um amplo programa de investimentos de infra-estrutura"(MARTINS, 1985) no território ${ }^{40}$. Faz-se mister também lembrar que outro importante dado daquele contexto foi essencial para a criação do BNDE: a influência da Comissão Econômica Para a América Latina (CEPAL), com todos os desdobramentos que a mesma teve no planejamento e na ação dos Governos da América Latina neste período. Vale lembrar que partiu dessa instituição o entendimento de que era necessário um organismo financeiro do Estado que alavancasse a possibilidade concreta de realização dos investimentos em infra-estrutura (RATTNER et alli: 1991).

No início da década de 1950, um dos principais problemas definidos pelo Governo Federal (então sob o comando de Getúlio Vargas) era o de realizar uma ampla melhoria em sistemas de engenharia e sistemas de movimento básicos do território, mormente nas áreas de energia e de transportes; ambos eram considerados os dois principais "gargalos" infra-estruturais do período. A expansão destes macrossistemas técnicos, porém, esbarrava em dois principais obstáculos:

1) a ausência de mecanismos tributários suficientes para o Estado financiar diretamente esses investimentos de grande monta;

2) a "incipiente formação do empresariado nacional", ou seja, a "ausência de grupos empresariais dinâmicos de grande porte e de comportamento moderno, que adotassem técnicas gerenciais compatíveis com a época e que

40 É também Luciano Martins que nos lembra que essa "Comissão Mista" refletia ainda "a ascensão hegemônica dos Estados Unidos no pós-guerra e, simultaneamente, exprimia uma nova tomada de consciência das elites locais sobre os problemas do subdesenvolvimento"(MARTINS, 1985:85). 
estivessem dispostos a investir em empreendimentos vultosos"[RATTNER et alli, 1991:36) ${ }^{41}$.

Definido este quadro, seriam formadas duas fontes básicas de financiamento do Banco: empréstimos externos (provenientes principalmente do Eximbank norteamericano e do Banco Mundial), e recursos de poupança interna (provenientes basicamente de receitas fiscais).

Como nos mostra o estudo de Henrique Rattner (et alli, 1991), podemos estabelecer a seguinte evolução da ação do BNDE no território brasileiro, para este período que iria de sua fundação (1952) até 1964. Entre os anos de 1952 e 1955, a ação do banco se pautou por uma "coordenação do esforço nacional de desenvolvimento econômico"(RATTNER et alli, 1991). Neste início de sua atuação, são priorizados os investimentos em dois principais sistemas de engenharia no território: o dos transportes ferroviários e o sistema de geração/transmissão de energia elétrica. Cerca de 54\% dos investimentos realizados pelo banco se dão no primeiro sistema, e cerca de $22 \%$ no segundo.

O que importa notar também é o caráter "antecipador" dos investimentos do Banco neste período, que indicam o início de ações fazendo parte de um planejamento econômico de longo prazo. Ainda que a prática do planejamento à época tenha favorecido a inserção posterior das empresas multinacionais no

\footnotetext{
${ }^{41}$ Peter Evans também lembra que o "espírito empresarial do Estado no setor financeiro" teve como tarefa inicial justamente "financiar investimentos públicos de infra-estrutura"(EVANS, 1980:226), sendo que o BNDE passaria a ser um dos principais instrumentos deste "espírito". Importa destacar, porém, que nos primeiros anos de formação do BNDE, o Banco seria muito mais um lócus de discussão/planejamento de políticas públicas, do que financiador/executor de obras propriamente dito. Luciano Martins, neste sentido, nos lembra que "na ausência de capitais, o Banco passa a acumular conhecimentos"(MARTINS, 1985:87). Dentre as principais características deste padrão inicial de funcionamento do Banco, podemos destacar: a) seus quadros adquirem e desenvolvem técnicas de análises de projetos, necessários à obtenção de financiamentos internacionais; b) os diretores da instituição passam a pensar em termos de uma "estratégia de ação global" a partir da idéia de subdesenvolvimento; esta idéia, por sua vez, tem raiz nas influências do pensamento cepalino (convênio CEPAL/BNDE), estabelecido desde 1953; c) financiando principalmente sistemas de engenharia sob comando da iniciativa privada (estrangeira e nacional), o BNDE seria também um instrumento essencial da construção do modelo tripartido (o "tripé") de industrialização adotado pelos governos militares, após o golpe de 1964 (EVANS, 1980). Para uma análise atual da ação do BNDES, ver também Silva Jr. (2006).
} 
País ${ }^{42}$, é possível afirmar que a ação do Banco imprime um caráter estratégico (ligado a um projeto nacional) ao financiamento dos principais macrossistemas do território.

Com a identificação do que seriam necessidades latentes das infra-estruturas econômicas nacionais, passa-se a fomentar, por exemplo, investimentos em sistemas de energia, já que estes se tornavam essenciais "(...) para o prosseguimento do processo de industrialização do Brasil, de modo a não se constituir em obstáculo à expansão industrial, com os investimentos sendo inclusive antecipados ao crescimento da demanda, principalmente no Sudeste"(RATTNER et alli, 1991:41).

Já entre os anos de 1956 e 1963, consolidado este período de formação do Banco, passaríamos a uma fase de "fomento das indústrias básicas" propriamente ditas (RATTNER et alli, 1991). Neste segundo subperíodo, o BNDE prioriza o investimento em empresas que fornecessem os insumos necessários ao desenvolvimento das indústrias de "bens de consumo duráveis" no território. Um dos ramos de atividade mais beneficiados com este esforço do BNDE foram as montadoras de automóveis, que se instalam no país a partir de meados da década de 1950. Iniciadas suas operações, estas empresas passam a demandar vários novos tipos de bens, principalmente produtos siderúrgicos.

A ação do BNDE, portanto, visava tanto construir no território brasileiro um complexo produtivo que atendesse essas novas demandas industriais, assim como buscava desonerar a balança comercial do país; o investimento em empresas produtoras de insumos básicos substituiria por produtos nacionais boa parte dos bens de produção que eram até então importados.

42 Para o geógrafo Milton Santos (1979a:5-28), neste período da história se inicia um processo de difusão do modo de produção capitalista que tem nos Estados dos países do Terceiro Mundo um elemento de dinamização. O planejamento econômico, neste sentido, serviria muito mais para a instalação das filiais de multinacionais na periferia do capitalismo, do que para a melhoria das condições de vida destas populações como um todo. 
Vejamos a tabela abaixo, que indica os tipos de dispêndios realizados pelo BNDE, englobando os dois subperíodos supracitados:

Tabela 6: Brasil: Evolução das Operações Aprovadas pelo BNDE, Segundo as Atividades Econômicas Beneficiadas (em Cr\$ milhões de 1981) (1953-1965)

\begin{tabular}{|l|r|r|r|r|r|}
\hline Atividades & \multicolumn{1}{|c|}{$\mathbf{1 9 5 3}$} & $\mathbf{1 9 5 6}$ & $\mathbf{1 9 5 9}$ & $\mathbf{1 9 6 2}$ & \multicolumn{1}{|c|}{$\mathbf{1 9 6 5}$} \\
\hline Siderurgia & 340,1 & 168,9 & $1.529,6$ & $12.914,1$ & $37.311,6$ \\
\hline $\begin{array}{l}\text { Insumos Básicos } \\
\text { Metalurgia }\end{array}$ & - & 49,9 & 142,4 & - & 652,8 \\
\hline Química e Fertilizantes & $1.224,5$ & $2.724,8$ & $3.408,7$ & $2.008,2$ & $2.390,1$ \\
\hline Celulose e Papel & - & - & 597,6 & - & 126,7 \\
\hline $\begin{array}{l}\text { Produtos Minerais Não- } \\
\text { Metálicos }\end{array}$ & - & - & 58,3 & - & 240,8 \\
\hline $\begin{array}{l}\text { Equipamentos Mecânicos e } \\
\text { Elétricos }\end{array}$ & - & 472,0 & 170,4 & - & $3.293,3$ \\
\hline $\begin{array}{l}\text { Equipamentos - Material } \\
\text { de Transporte }\end{array}$ & - & - & $5.231,6$ & 273.1 & $2.073,3$ \\
\hline $\begin{array}{l}\text { Indústria - Têxtil e de } \\
\text { Calçados }\end{array}$ & - & - & - & - & 721,4 \\
\hline Produtos Alimentícios & - & - & - & 40,2 & $1.563,9$ \\
\hline Outras & - & - & - & 36,6 & $1.932,2$ \\
\hline
\end{tabular}

Fonte: BNDES; adaptado de RATTNER et alli (1991:49)

Como nos mostra a tabela, os setores privilegiados pelo financiamento do Banco eram quatro principalmente: a) siderurgia; b) química e fertilizantes; c] equipamentos mecânicos e elétricos; e d) equipamentos/material de transporte.

Se lembrarmos que todos podem ser considerados como setores que fornecem "insumos básicos" às atividades industriais, vemos que o Estado brasileiro estava através do Banco - preparando o território para o fornecimento de bens intermediários voltados para a instalação e a densificação do meio técnicocientífico no país. Seja pela utilização dos fertilizantes nas áreas de produção agrícola, seja pela utilização de produtos químicos (derivados de petróleo, plásticos, e produtos para a indústria alimentícia), dos produtos siderúrgicos, dos insumos ao setor elétrico, uma base de insumos industriais de toda sorte passa paulatinamente a ser produzida em moldes nacionais, aumentando a autonomia do País em importantes circuitos produtivos. 
Este é, portanto, um quadro passível de ser desenhado, para o melhor entendimento de um dos Bancos que viria a ser o pilar dos financiamentos das infra-estruturas construídas em território nacional. Assim como os demais bancos federais, o BNDE ajuda na manutenção de um desenvolvimento ao mesmo tempo integrado e diversificado das infra-estruturas produtivas nacionais, adequando a circulação de capital financeiro às vicissitudes dos demais conteúdos do território.

Estes esforços somados permitiram que fossem mantidas estruturas produtivas mais regionalizadas, como vimos para o caso da Amazônia e do Nordeste. Em relação ao BNDE, podemos dizer que através dele é aumentada a possibilidade de controle dos processos básicos da industrialização pesada, em termos mais soberanos. Apesar da internacionalização de algumas indústrias importantes, a internalização de vários circuitos produtivos estratégicos permite uma inserção mais ativa do país no período técnico-científico que adentrávamos ${ }^{43}$.

Para completarmos este quadro do sistema financeiro público brasileiro neste segundo subperíodo do estudo (1945-1964), passemos então à análise da atuação dos dois bancos públicos que permitem também um controle mais regionalizado das finanças do País.

\subsection{Os bancos públicos estaduais e a ação do Banespa e da Caixa Econômica do Estado de São Paulo}

Conforme preconizam tanto a teoria do federalismo fiscal (OATES, 1977), quanto a "geografia das finanças públicas" (BENNETT, 1980), a manutenção de certa descentralização das finanças de uma nação pode ser um importante instrumento para a otimização da utilização dos recursos fiscais e financeiros da mesma.

\footnotetext{
${ }^{43}$ Data deste período também a forte internacionalização de alguns setores econômicos, como o da indústria automobilística e de bens de capital. Para uma análise crítica deste processo ver L. A. Moniz Bandeira (1979: capítulo 1). Para o autor, no período posterior a Segunda Guerra Mundial, "o Brasil cresceu, sem dúvida, mas, apoiado na expansão da indústria de bens de consumo (automóveis, eletrodomésticos etc.), comandada pelo capital estrangeiro, cujos países de origem procuravam a todo custo reservar-se a produção de bens de capital, a tecnologia e o nervo financeiro, como condição de sua preponderância”(MONIZ BANDEIRA, 1979:13).
} 
Pensando neste raciocínio, é possível entender porque no período em tela não só no nível federal é que vemos ser criadas instituições que trabalhassem para a organização das finanças em moldes mais regionais. Também no nível estadual novos bancos são criados, no sentido de dotar as escalas menores da federação de um maior controle sobre suas práticas de financiamento.

Em 1944 o antigo Banco Hipotecário e Agrícola de Minas Gerais (criado em 1911) é transformado no Banco do Estado de Minas Gerais (BEMGE). São criados ainda, no Rio de Janeiro, o Banco da Prefeitura do Distrito Federal (1945) e o Banco de Crédito do Estado do Rio de Janeiro (1950), que viriam a se transformar, também em 1950, no Banco do Estado do Rio de Janeiro (BANERJ). Neste mesmo contexto, segundo Yttrio Costa Neto (2004:52 e seguintes) são criadas ainda as seguintes instituições financeiras estaduais:

1955 - Banco do Estado de Goiás (BEG)

1958 - Banco do Estado do Amazonas (BEA)

1958 - Banco Comercial e Agrícola do Piauí (BEP)

1960 - Banco de Fomento do Estado da Bahia (BANEB)

1961 - Banco do Estado do Pará (BANPARA)

1962 - Banco de Desenvolvimento do Estado de Santa Catarina (BESC)

1962 - Banco de Desenvolvimento do Estado de Pernambuco (BANDEPE)

1963 - Banco da Produção do Estado de Alagoas (PRODUBAN)

1963 - Banco de Fomento do Estado de Sergipe (BANESE)

1963 - Banco do Estado de Mato Grosso (BEMAT)

1964 - Banco do Estado do Ceará (BEC)

1964 - Banco da Produção e do Fomento do Acre (BANACRE)

Vale lembrar ainda que é na década de 1960 que são criadas outras duas Caixas Econômicas no território brasileiro: a Caixa Econômica Estadual do Rio Grande do 
Sul (CEERS) em 1960 e a Caixa Econômica do Estado de Goiás (CAIXEGO), em 1962 [COSTA NETO, 2004:54) ${ }^{44}$.

Um dos dados comuns dos bancos oficiais no período é o fato de estarem engajados numa maior regionalização da ação bancária, e o Banespa não fugia a esta regra. Como mostra o Relatório do Exercício de 1947 do Banco, era

“(...) indispensável que se dê (desse), (...) ao sistema bancário nacional, uma estrutura verdadeiramente conforme as reais necessidades do país, e ajustada às peculiaridades das diferentes zonas geoeconômicas em que se desenvolvem as mais variadas e multiformes atividades patrícias" [apud COSTA, 1988:231).

Fundado numa parcela do território em que o processo de urbanização e de industrialização conheceram uma dinâmica bastante vigorosa (MATTOS, 1958; CANO, 1977, 1983), também as operações bancárias realizadas pelo Banespa aferiam uma rentabilidade bastante superior em relação aos demais bancos estaduais. A partir da década de 1950, a exemplo do que ocorria com a maior parte dos bancos oficiais, observamos também uma atuação regional do Banespa a serviço da transformação do sistema de objetos sob sua influência, reflexo do período "desenvolvimentista" que o país atravessava. O Banespa, neste período

\begin{abstract}
"concedeu financiamentos específicos aos contratantes de mão-de-obra, de preferência aos empreiteiros de pavimentação de estradas de rodagem. Fez adiantamentos às empresas hidroelétricas e industriais do Estado, aos Departamentos de Água e Esgoto e de Estradas de Rodagem, às estradas de ferro governamentais e a outros empreendimentos de idêntica natureza. Devidamente autorizado pelo governo do Estado, concedeu aval ou fiança a contratos de entidades estatais, ou ligadas ao Estado, possibilitando assim, o desempenho de atribuições de interesse público"(COSTA, 1988:248).
\end{abstract}

O banco atua, portanto, para a incorporação na região de uma série nova de conteúdos técnicos que iriam contribuir ainda mais para o reforço do dinamismo do Estado. É o caso do desenvolvimento dos transportes terrestres, que aumentam sobremaneira as quantidades e o alcance dos fluxos de bens e

44 Até esta data só havia no território brasileiro a Caixa Econômica do Estado de Minas Gerais (MINASCAIXA), criada no ano de 1896, assim como a Caixa Econômica do Estado de São Paulo, instituída em 1917. 
mercadorias no Estado (MONBEIG, 1952, 1984; BARAT, 1978). É também o caso do surgimento e da difusão dos estabelecimentos do ensino superior, tanto na capital, quanto no interior, que permitiriam uma banalização maior do acesso ao conhecimento formal para sua população (PASTORE, 1971). Esses, entre outros sistemas técnicos e organizacionais que são paulatinamente instalados, vão permitir a transição de um sistema montado para a exportação do café, para um voltado para circuitos mais urbano-industriais, com forte propensão ao consumo da população urbana.

Esta era, portanto, parte da realidade sobre a qual o Banespa realizava sua atividade bancária. E o fato de ser um banco público ajudou muito esse processo de industrialização em marcha, como mostra ainda o estudo de Fernando Costa (1988): apesar de cerca de $2 / 3$ dos depósitos do Banespa serem provenientes do governo do estado, não era o Tesouro estadual o principal recipiendário destes capitais. Para o autor (COSTA, 1988:249), “a maior parte destes (recursos) destinava-se às atividades industriais; peso significativo também teve o financiamento à comercialização, seja da produção agrícola, seja de matérias-primas e vendas de produtos das indústrias".

Já a Caixa Econômica do Estado (criada em 1917, como vimos) cumpriria uma função diferente, nesta dinâmica divisão bancária do trabalho instalada em São Paulo. Em primeiro lugar, ela continua exercendo a função de receptora das poupanças das famílias e trabalhadores urbanos (incluindo aí os funcionários públicos), que aumentavam sua participação nos circuitos produtivos da região ${ }^{45}$.

Talvez a grande novidade nas operações realizadas pela Caixa no período seja a constituição de uma "carteira de financiamentos"; isto é, ela atua também no sentido de irrigar o Estado com os recursos arrecadados de sua população, e não

45 Como mostra o próprio documento da Caixa à época, "as caixas econômicas constituem, ainda, para todo o povo, o meio fácil e pronto de que pode lançar mão para garantir o futuro através de um pecúlio seguro"(NOSSA CAIXA, 2002:49). 
só captar os depósitos junto ao público regional. Os principais destinatários de empréstimos eram tanto pessoas físicas, quanto municipalidades; via de regra os capitais concedidos eram investidos na construção de habitações (NOSSA CAIXA, 2002:49), um bem já à época bastante ligado às necessidades das populações urbanas assalariadas ${ }^{46}$.

Com relação à topologia da Caixa Econômica do Estado de São Paulo, vale destacar o considerável crescimento de sua rede de agências, em relação aos períodos anteriores (1918 e 1930). Entre 1930 e 1945, foram criadas nada menos que 144 agências (Mapa 3); já entre os anos de 1946 e 1964, são instaladas 310 agências (Mapa 4). Segundo dados do economista Raymond Goldsmith, São Paulo comandava em 1947 cerca de 55\% dos totais depositados em Caixas Econômicas no território brasileiro (incluindo a Caixa Econômica Federal); em 1954, esse percentual é de 47,6\%, e chega no ano de 1964 representando $41,9 \%$ dos totais $(1986: 271)^{47}$.

Esse expressivo crescimento pode ser considerado, em primeiro lugar, como um dado daquele período histórico específico. Como nos mostra Wanderley Guilherme dos Santos (1987), durante todos os anos do Estado Novo, assim como nos primeiros anos do pós-Guerra, tanto o Governo Federal como os governos estaduais criam uma série de institutos vinculados a questões previdenciárias, de pensões e aposentadorias.

Data do Estado Novo o que o autor chamou de "extensão regulada da cidadania"(DOS SANTOS, 1987) já que os processos de crescimento populacional, urbanização e divisão social do trabalho que se instalavam induzem à

\footnotetext{
${ }^{46}$ Como mostra também documento da época da Caixa, a habitação era considerada como um "perene ideal", e ter uma 'casa própria' seria a forma de fugir "assim do desassossego e ao ônus pesadíssimo das moradias de aluguel" (NOSSA CAIXA, 2002:49).

47 As Caixas Econômicas estaduais eram instituições fortes basicamente nos Estados de São Paulo e de Minas Gerais; segundo Carlos Passos, ao final deste período de grande "institucionalização" do sistema financeiro (1946-1964), das 1.709 agências de Caixas Econômicas existentes no território, 555 pertenciam à Caixa Econômica do Estado de São Paulo $[32,5 \%$ dos totais $)$ e "521 ao Estado de Minas Gerais [30,5\%)"(PASSOS, 1973:30).
} 
implementação de uma série de políticas públicas que garantissem direitos sociais básicos para a população ${ }^{48}$.

Esse aumento da regulação do Estado também sobre as chamadas "políticas sociais" tem relação direta com o crescimento da importância da Caixa Econômica do Estado de São Paulo. As Caixas Econômicas, no geral, são instituiç̧ões com vocação semelhante, por operarem com cadernetas de poupança, e não terem as prerrogativas de um banco comercial comum. Destarte, podem ser consideradas muito mais como agentes de promoção de políticas "horizontais" nas regiões onde estão instaladas.

Com relação à topologia da Caixa Econômica do Estado de São Paulo, é passível de ser destacado dos Mapas 3 e 4 que, em 1945, a distribuição das agências no território passa a depender menos das redes ferroviárias para sua difusão.

\footnotetext{
${ }^{48}$ Dentre os eventos que representavam o aumento gradativo da preocupação governamental com o tema, podemos destacar: 1931 - Criação do Ministério do Trabalho, Indústria e Comércio, através do qual "seriam providos os meios materiais e humanos para a execução e fiscalização da legislação trabalhista e previdenciária"(DOS SANTOS, op. cit.27); 1932 - através dos decretos 21.186 de 22 de março e do 21.364 de 4 de maio ficava estabelecida a jornada de trabalho de oito horas diárias, "respectivamente para os comerciários e para os trabalhadores na indústria"(idem:27); 1934 - Criação de Institutos de Previdência como o Instituto de Aposentadoria e Pensões dos Marítimos (IAPM), Instituto de Aposentadoria e Pensões dos Comerciários (IAPC), Instituto de Aposentadoria e Pensões dos Bancários (IAPB), Instituto de Aposentadoria e Pensões dos Industriais (IAPI), entre outros; 1943 - Promulgação da Consolidação das Leis do Trabalho (CLT), que passaria a abranger "todas as pessoas ocupando posições no processo de acumulação, reconhecidas e reguladas pelo poder estatal"(DOS SANTOS, 1987:30).
} 


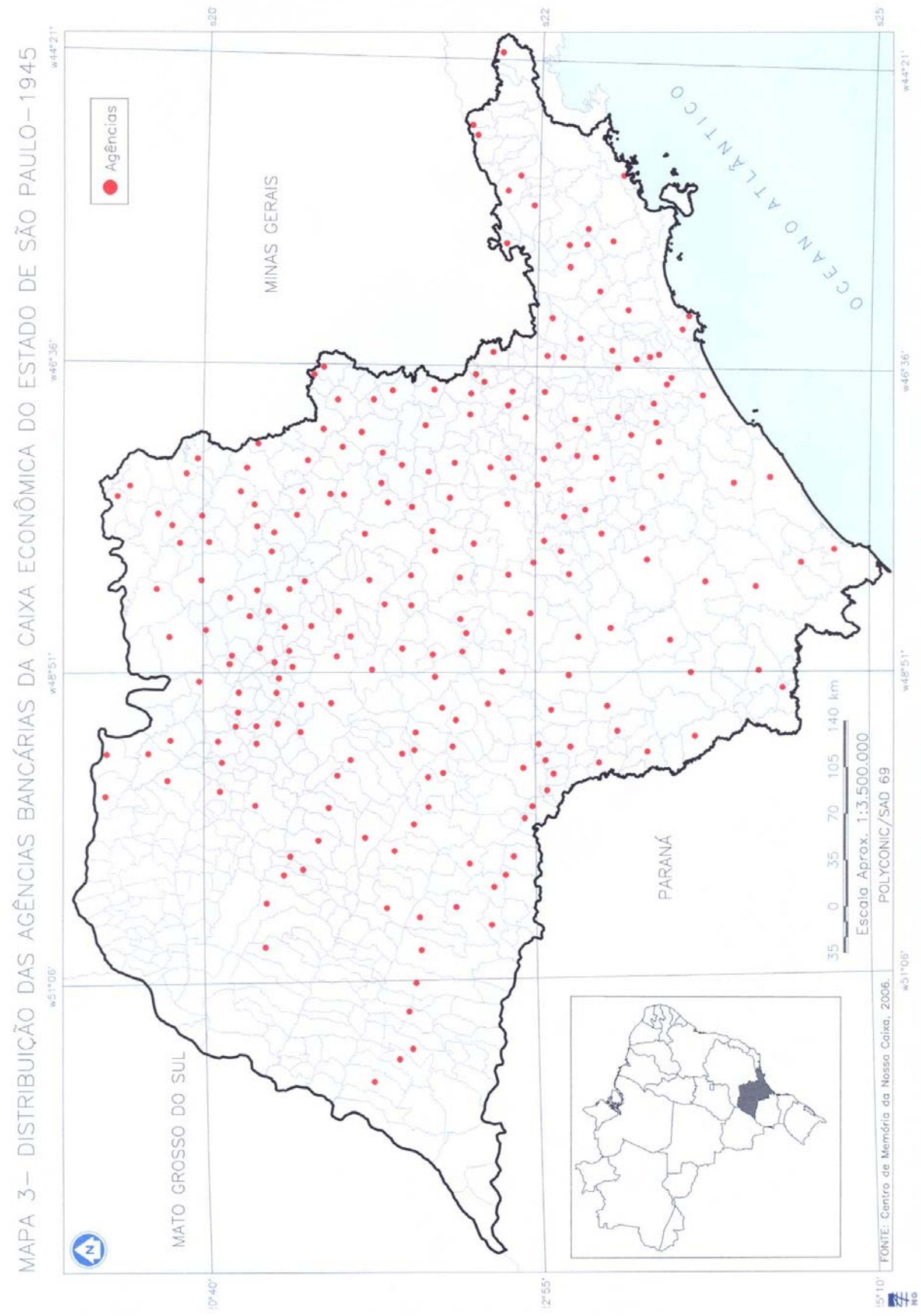




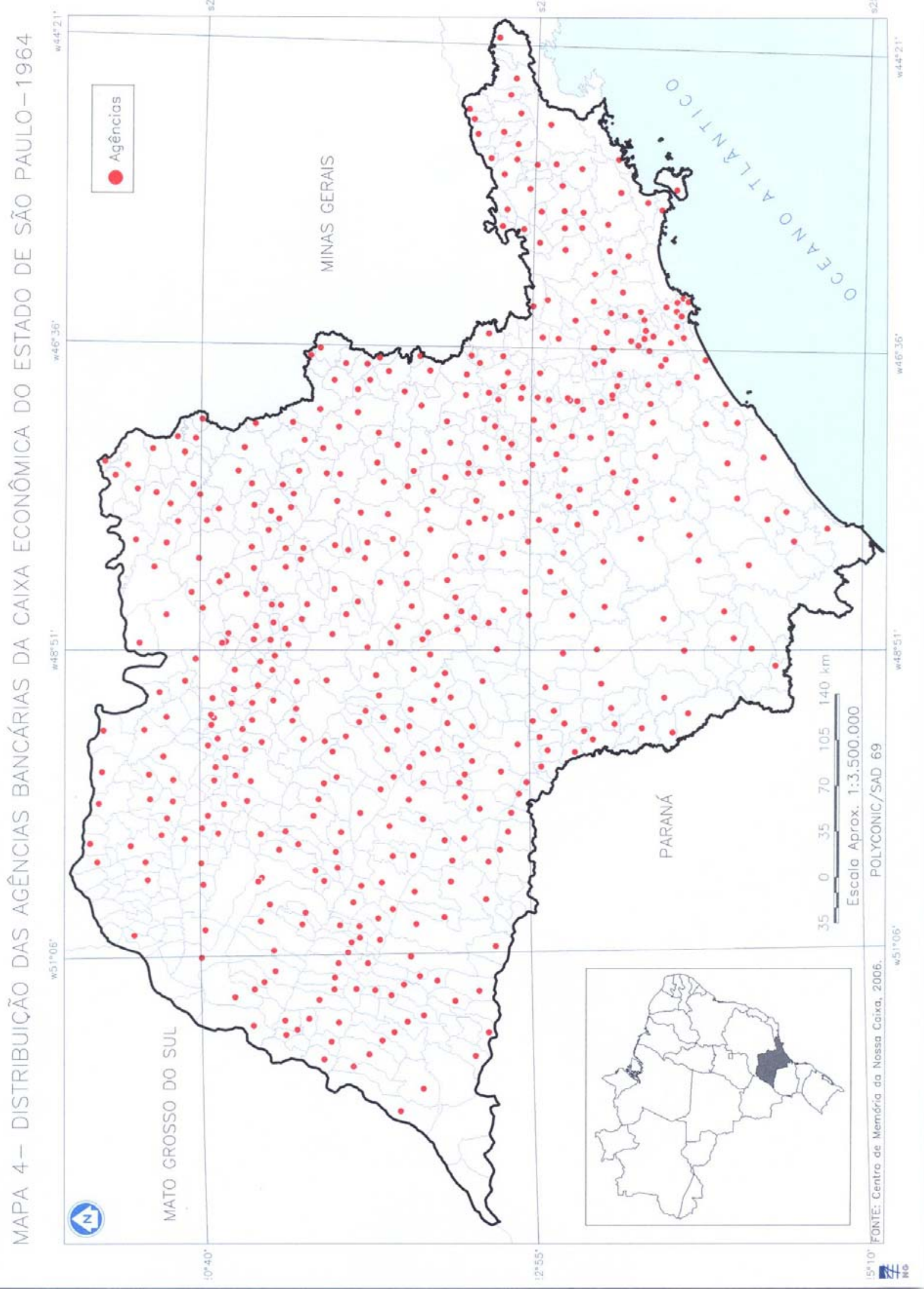


Podemos inferir que, com a banalização das estradas de rodagem e dos automóveis como veículos para o deslocamento de passageiros e cargas no estado (MARQUES, 1978), também a topologia dos bancos é flexibilizada. Para parafrasear Pierre Monbeig $(1952,1984)$, parece ser também possível afirmar que a rede de agências da Caixa Econômica conhece uma "marcha pioneira" em direção ao Oeste do estado.

Por último, mas não menos importante, o próprio aumento da quantidade de depósitos, assim como da importância da Caixa Econômica no contexto da divisão bancária do trabalho na região, requer uma reorganização de seu sistema de ações, em bases mais racionalizadas. Como mostra o documento da Caixa, datado de 1951:

“Em face do notável volume das operações, tanto na sede-matriz como nas agências da Capital e do interior, resolveu a Administração pleitear ao Sr. Governador se dividisse o território do Estado em "regiôes", para melhor fiscalização e controle dos serviços, o que se conseguiu pelo Decreto no. 21.146, expedido em 14 de janeiro de 1952, o qual criou catorze regiões denominadas "agências regionais"” (NOSSA CAIXA, 2002:49).

Desta necessidade de um controle mais racionalizado das operações bancárias da instituição nasce, portanto, uma nova regionalização interna da Caixa. Essa regionalização seria assim definida:

$1^{\text {a }}$. Região: Capital

$2^{\mathrm{a}}$. Região: Santos

3a. Região: Taubaté

$4^{\text {a }}$. Região: Campinas

5a. Região: Araraquara

6а. Região: São José do Rio Preto

$7^{\text {a }}$. Região: Ribeirão Preto

8a. Região: Sorocaba

9a. Região: Botucatu

10a. Região: Presidente Prudente

$11^{\text {a }}$. Região: Bauru 
12 ${ }^{\mathrm{a}}$. Região: Araras

13a. Região: Rio Claro

14a. Região: Marília

Esta regionalização implementada pela Caixa Econômica do Estado de São Paulo pode ser considerada, assim, como mais um esforço de adequar os sistemas de ação estatais às vicissitudes locais e/ou regionais das populações do estado. A bem da verdade, como mostram Jean Jacques Dayries e Michele Dayries (1978:14-15), quando é aumentada a "complexidade das tarefas" numa realidade regional, é incrementada também a "necessidade de proximidade", e de "desconcentração administrativa" das instituições de planejamento. A regionalização da estrutura de ação da Caixa Econômica do Estado pareceu ser também um exemplo deste fenômeno. 
No início do século $\mathrm{XX}$, apesar de já haver atividades econômicas bastante dinâmicas sendo desenvolvidas no território, a concessão de créditos para elas era em grande parte suprida por atores não-bancários. Esse era o caso dos "comissários do café" na Região Sudeste do país, assim como o do "sistema de aviamento", na região amazônica. Esses sistemas de ação criavam dificuldades para que se consolidasse no Brasil um processo de intermediação financeira baseado em instituições bancárias.

Outro fator que parece ter influenciado essas dificuldades iniciais dizem respeito à própria base técnica do território. Em função de não existir uma rede de transportes internos desenvolvida em toda a extensão do país, as regiões produtivas eram mais isoladas. A alteração desta base técnica, a partir das primeiras décadas do século $X X$, confere outro dinamismo às regiões produtivas do país, apesar de manter a desarticulação física do território. Através da renovação dos sistemas de movimento do território - sendo a construção de ferrovias a maior novidade técnica deste início de século - foi possível incrementar a velocidade dos fluxos produtivos, seja de mercadorias ou de pessoas. Esse quadro permite um importante processo de urbanização de parcelas do espaço nacional. Esta urbanização, por seu turno, gera uma quantidade nova de tipos de consumo que vão catalisar uma industrialização expressiva em algumas parcelas do território.

Em função da evolução destes conteúdos técnicos do território é que vão surgir as primeiras redes bancárias regionais. Surgidas a princípio para auxiliar os circuitos de exportação de commodities agrícolas (como foi o caso do Banco Agrícola e Hipotecário do Estado de São Paulo), essas redes vão paulatinamente sendo utilizadas para drenar as rendas urbanas geradas pelo dinamismo das regiões produtivas. O surgimento da Caixa Econômica do Estado de São Paulo é em grande parte um resultado desse dinamismo. Mas com um aspecto peculiar: a 
Caixa Econômica tem sua topologia vinculada aos demais fixos públicos que eram instalados nas cidades paulistas: redes de coletorias de impostos, empresas de prestação de serviços urbanos, autarquias municipais etc. Até o ano de 1945, portanto, os sistemas de ação são bastante regionais, ou mesmo locais. As técnicas agrícolas - ainda que algumas regiões tenham se industrializado expressivamente são ainda a variável-chave desse subperíodo.

Além das novidades relacionadas à institucionalização e normatização do sistema financeiro, como a criação de Câmaras de Compensação, da Carteira de Emissão e Redescontos, o aumento da importância da circulação financeira no território faz alterar também a topologia bancária do País. A par de um aumento do número de agências, é diminuído o número de atores do sistema bancário.

A criação da Superintendência da Moeda e do Crédito (a SUMOC) é a grande novidade desse subperíodo (1945-1964), já que vai centralizar o comando das instituições financeiras no Brasil. Pela primeira vez na história, o País tem um ator que determina os conteúdos normativos referentes às finanças nacionais. A SUMOC age também no sentido de racionalizar a divisão bancária do trabalho, criando as chamadas "financeiras", principalmente para catalisar o consumo dos bens duráveis, que passam a ser produzidos no território brasileiro. Se aumenta a racionalidade dos sistemas técnicos instalados, também os sistemas de ações se tornam mais racionais.

O acréscimo de sistemas de engenharia de grande porte no território vai demandar capitais de longo prazo para seu financiamento. Como mostram Adenot e Albertini (1975:105), para a construção de equipamentos industriais, barragens e grandes infra-estruturas são necessárias instituições financeiras que recolham a poupança de empresas e atores particulares, possibilitando assim financiamentos em prazos mais dilatados. 
A criação do Banco Nacional de Desenvolvimento Econômico (BNDE), em 1952, vem suprir estas vicissitudes da expansão do meio técnico-científico no País. O Banco passa a financiar demandas cujo tempo de maturação não permitiam ser supridas pelo sistema bancário existente. Os recursos, por sua vez, eram em grande parte provenientes dos Estados Unidos (através de seu Eximbank). Apesar dos financiamentos serem em grande parte externos, o sistema de ações do BNDE era o decididor da alocação dos recursos; o dinheiro forâneo, portanto, não incidia verticalmente no território. Nesse subperíodo, as técnicas industriais passam paulatinamente a se constituir na "variável-chave" dos usos possíveis do território.

O que pode ser dito do sentido do uso do espaço brasileiro neste período? Quais as possibilidades de usos mais autônomos do território, manifestados no período da "gênese do moderno sistema bancário brasileiro"? E quais os elementos do espaço que permitem que falemos num aumento da dependência de vetores externos ao território? As finanças "controlavam as regiões", ou as regiões "controlavam as finanças"?

Há elementos concretos da análise que permitem afirmar que o uso do território à época era voltado para o fortalecimento da vida regional, apesar do processo de internacionalização de partes dos sistemas de ação produtivos existentes. No início do século, podemos dizer que a própria estrutura da indústria, descentralizada (e com amplitude de mercado regionalizada), era a manifestação do sentido orgânico dos sistemas de ação presentes no território. O mesmo pode ser dito da pulverização do controle bancário: no início do século, com os chamados "bancos emissores regionais", havia clara submissão das finanças à vida regional do território. E mesmo com a gênese do moderno sistema bancário, até 1945 as regiões (e mesmo algumas cidades no interior) possuíam seus bancos próprios, comandados pelo que poderíamos chamar de "classes sócio-espaciais" (REYNAUD, 1981) regionais. 
Mesmo após a criação da SUMOC, é possível ainda afirmar que a estrutura regionalizada da ação bancária era um elemento de criação de solidariedades orgânicas $^{49}$ no território. Fossem elas instituições privadas, fossem elas instituições oficiais, sua ação estava concatenada com as vicissitudes do desenvolvimento de cada região onde estavam instaladas as instituições. A criação de uma rede de bancos públicos estaduais também é manifestação da criação de solidariedades orgânicas nesse período da vida do País.

Quais os elementos do território, porém, que permitem dizer que começam a ser instaladas neste período solidariedades organizacionais ${ }^{50}$ no espaço nacional? Isto é, quais os atores, circuitos e fluxos instalados que alteram essa possibilidade de um desenvolvimento mais horizontalizado ou regionalizado da nação?

No início do século, a ação dos bancos estrangeiros pode ser considerada como um dado do funcionamento do espaço mais próximo da criação de solidariedades organizacionais no país. Principalmente por seu imbricamento com os circuitos geográficos da exportação de commodities agrícolas (como era o caso do café, da borracha, do açúcar), mas também por seu papel de fomento de atividades comerciais de importação e exportação; os bancos estrangeiros atuavam no sentido

\footnotetext{
${ }^{49}$ A solidariedade orgânica, como asseveram Milton Santos e María Laura Silveira, “(...) resulta de uma interdependência entre ações e atores que emana da existência do lugar. Na realidade, ela é fruto do próprio dinamismo de atividades cuja definição se deve ao próprio lugar enquanto território usado. É em função dessa solidariedade orgânica que as situações conhecem uma evolução e construções locais relativamente autônomas e apontando para um destino comum"(SANTOS e SILVEIRA, 2000:306/307). As solidariedades orgânicas são formas de uso do território que permitem uma organização da vida regional mais autônoma, equilibrada, e que leva em conta as vicissitudes de todos os sistemas de ação presentes numa região. A partir delas é que se formam as redes de cooperação (econômica, social, política, cultural) que permitem uma reprodução mais autocentrada das diferentes parcelas do território.

${ }_{50}$ As solidariedades organizacionais, par contre, seriam fundadas pelo predomínio de lógicas externas às regiões, e que passam a moldar seu funcionamento a partir de vicissitudes que não necessariamente dizem respeito à vida local. Este tipo de solidariedade, portanto, decorre de "arranjos organizacionais, criadores de uma coesão organizacional baseada em racionalidades de origem distantes, mas que se tornam um dos fundamentos de sua existência e definição" (SANTOS, 1996:226). No caso dos lugares onde predominam as solidariedades organizacionais, não são tanto as redes de cooperação que se formam, mas sim redes de competição, que desarranjam (muito mais do que organizam) a vida local ou regional. Ver ainda Silveira (1994; 1996) e Castillo, Toledo Jr. e Andrade (1997).
} 
de introduzir lógicas externas ao processo de organização da vida regional brasileira. 51

Por fim, mas não menos importante, a ação da SUMOC e do BNDE imprimem no território ações que se aproximam em certos momentos da constituição de solidariedades orgânicas, mas em alguns momentos de solidariedades organizacionais.

No caso da SUMOC, a normatização em relação à distribuição das agências bancárias parece ser claramente uma política de consecução de solidariedades orgânicas no espaço nacional. Sua política relativa à topologia do sistema bancário nacional (que buscava uma maior dispersão da atividade bancária no território) não era resultado das necessidades "organizacionais" das firmas bancárias aqui instaladas; a concessão de cartas-patente, e sua preocupação distributiva, agia no sentido de tornar a densidade financeira do território mais equilibrada.

A mesma SUMOC, porém, acabou por permitir que um processo de concentração bancária viesse a ocorrer, diminuindo o número de atores do sistema bancário brasileiro, e contribuindo assim para um início da centralização do comando financeiro do território no período. Por esta dinâmica implementada, a SUMOC pode ser considerada também uma instituição que imprimiu solidariedades organizacionais no espaço nacional. As regiões se tornam mais alienadas, sem o controle efetivo das sedes de suas instituições bancárias.

No caso do BNDE, sua ação no sentido de dotar o espaço brasileiro de sistemas de engenharia mais modernos pode ser considerada como um dado de consecução de solidariedades orgânicas na vida nacional. Tanto pela diversificação produtiva que estes sistemas de engenharia permitem, quanto pela possibilidade de serem realizados financiamentos em prazos mais longos no País, o BNDE instala usos do

\footnotetext{
${ }^{51}$ A própria topologia do sistema de movimento ferroviário, neste período, é um elemento do território que contribuía muito mais para aumentar as relações das regiões produtivas do país com o exterior, do que na formação de um mercado nacional mais integrado.
} 
território mais voltados para o desenvolvimento endógeno da nação. Par contre, a utilização dos recursos provenientes do Eximbank para o financiamento da renovação da base técnica, imprime um caráter mais "organizacional" à ação do Banco.

O Estado é o maior coordenador da organização do espaço nacional, e não o mercado. A finança, por sua vez, permanece como um conteúdo do território como os demais (industriais, urbanos, de transportes etc.). Não há uma autonomização do "dinheiro" no governo dos objetos e das ações que compõem o arranjo espacial do período. A finança obedece ainda a vida regional do país, e não o contrário. 


\section{PARTE 2 - A CREDITIZAÇÃO E A INTEGRAÇÃO DO TERRITÓRIO NACIONAL (1964-1994)}




\section{CAPÍTULO 5. Urbanização, Integração e Creditização do Território}

A partir de meados da década de 1960, o território brasileiro entra numa nova fase de desenvolvimento. São alterados conteúdos técnicos essenciais de sua constituição, dos quais parecem merecer destaque os sistemas de movimento, as formas do fazer industrial, os circuitos da produção agrícola e os sistemas de telecomunicação. Teremos a oportunidade de voltar a cada um destes temas nos itens que seguem deste capítulo.

Estes conteúdos permitem outras possibilidades de uso do espaço geográfico, com reflexos também no sistema bancário e financeiro. As instituições bancárias precisarão acompanhar as novas necessidades de financiamento das atividades econômicas, que se multiplicam num espaço geográfico cada vez mais integrado, diversificado e tecnicizado.

A situação política do país também se complexifica. Paula Beiguelman (101 e ss.) nos lembra que no campo, há uma "desintegração das estruturas locais de poder político", assim como nos meios urbanos, tanto os sindicatos como os movimentos estudantis "passam a se perceber como uma força política em ascensão". São incluídas, destarte, novas demandas na pauta das necessidades públicas nacionais. As multinacionais aumentam também sua capacidade de interferir na cena política, dada sua forte presença em setores produtivos estratégicos. Deste campo de forças mais polarizado, podemos dizer junto de Raimundo Faoro (1981) que segue um "esgotamento institucional", e tanto um golpe de Estado ${ }^{52}$ como uma Nova Constituição são instituídos no país em 1964. Alteram-se, novamente, também os conteúdos normativos do território.

\footnotetext{
52 Com relação ao golpe de 1964, Wanderley Guilherme dos Santos afirma que “a vazão dos conflitos sociais para fora das instituições herdadas do Estado Novo não encontrou resposta institucional à altura, tendo por resultado líquido a radicalização das demandas e a intolerância política crescente dos diferentes atores sociais, as quais, associadas à capacidade cadente do Estado de produzir e de alocar recursos, terminaram por produzir o contexto de paralisia governamental e administrativa de fins de 1963 e princípios de 1964, que, em parte, ajudam a explicar o movimento militar de 1964"(DOS SANTOS, 1979, 1987:74/75).
} 
Os esforços seguidos pelo Governo Militar instalado em 1964 logram uma integração física do território jamais vista na história do país. Essa integração, junto do aumento do mercado consumidor presente nas cidades brasileiras, vai tornar ainda mais atrativo o espaço nacional para algumas firmas estrangeiras; mas vai possibilitar, sobremaneira, que grandes empresas estatais e privadas nacionais sejam criadas, e assumam parte significativa da condução da organização do território.

Com relação às instituições financeiras nacionais, é possível dizer que sofrem também uma mudança expressiva na sua topologia, na sua forma de organização, assim como na quantidade e diversidade dos atores envolvidos. Para Raymond Goldsmith (1986:361), neste período, "as instituições e os instrumentos financeiros mudaram mais significativamente do que no século precedente em sua estrutura, além de se diversificar, resultando na criação de uma superestrutura das instituições e instrumentos financeiros ampla com relação à grandeza da economia, e muito mais variada do que em quase todos os países subdesenvolvidos".

\subsection{A urbanização do território e as novas necessidades de consumo}

Assistimos nas décadas de 1960 e 1970 um incremento sensível do processo de urbanização do território brasileiro. Fruto tanto do crescimento demográfico natural da população, quanto da atratividade que as cidades passam a exercer nas populações rurais, este incremento é ainda resultado do avanço do meio técnicocientífico nas áreas rurais do país (SANTOS, 1993:35-47). A introdução de modernos objetos técnicos nos cultivos agrícolas (como veremos no item 5.2) aumenta as quantidades de capital e tecnologia no campo, dispensando parcelas grandes de mão-de-obra, que acabarão por migrar para áreas urbanas do espaço nacional.

A julgar pelos números envolvidos no processo de urbanização, vemos que de fato a década de 1960 é um momento de mudança no padrão de ocupação do 
território: se em 1950 o índice de urbanização da população era de 36,16\%, em 1960 ele passa a 45,5\%, para chegarmos no ano de 1970 com 56,8\% da população brasileira urbanizada (SANTOS, 1993:29).

Esta evolução dos conteúdos demográficos do território mostra uma concentração da população em pontos selecionados do espaço, isto é, nos meios urbanos. Para qualificarmos melhor este processo, porém, pareceu-nos ainda necessário chamar a atenção para dois outros fenômenos que balizaram a urbanização no período: a) a formação de cidades médias e b) a metropolização da vida no território (SANTOS e SILVEIRA, 2001:202 e seguintes) $)^{53}$.

Como notam Milton Santos e María Laura Silveira (2001), crescem com vigor nesse período ao menos três tipos de aglomerações no território: as "cidades locais" (com mais de 20 mil habitantes), as "cidades médias" (com mais de 100.000 habitantes) e as metrópoles (cidades com mais de 1.000 .000 de habitantes). Porque é necessário chamar a atenção para essa nova forma de distribuição da população no espaço nacional?

Em primeiro lugar, é importante destacarmos o crescimento das cidades locais e médias neste período pois é nelas que novas funções urbanas são geradas; formase, por exemplo, um contingente considerável de postos de trabalho em atividades burocráticas, voltadas para as necessidades de organização administrativa local (prefeituras, autarquias). Com relação às atividades privadas, surgem com mais força as chamadas "profissões liberais", isto é, um contingente de trabalhadores voltados para a prestação de serviços médicos, de assistência jurídica, na área da construção civil etc. A chamada "classe média", isto é, esses contingentes de população tipicamente urbanos, vendedores de sua força de trabalho, é que vai

53 Data deste período também a expansão do processo que a geógrafa Maria Adélia de Souza qualificou de verticalização das metrópoles brasileiras. Esta expansão deu-se principalmente através da ação dos "incorporadores urbanos", com suas variadas alianças com o Estado nas dimensões nacional e municipal. A partir deste período, "produzir cidades, metrópoles ou megalópoles passou a ser um grande negócio”(SOUZA, 1994:236). 
impulsionar demandas por novos consumos, bastante vinculados ao incremento da industrialização, e do reforço do próprio processo de urbanização.

Para o geógrafo Milton Santos (1993:73), é importante também destacar o processo de formação das cidades locais e médias do país nesse período pois, nelas, os seguintes processos passam a compor a reprodução cotidiana da vida das pessoas:

1) São expandidas e diversificadas as necessidades de consumo;

2) São elevados os níveis de renda da população, em comparação ao que ocorria no meio rural;

3) São criados e difundidos nestes centros urbanos novos meios e novas infraestruturas de transporte;

4) Ocorre uma divisão do trabalho mais acentuada, com aumento da produtividade dos processos econômicos, e maior excedente de riqueza gerado;

Processo semelhante, em escala maior, se dá com as chamadas cidades milionárias (com mais de 1.000.000 de habitantes), ou metrópoles. Na década de 1960 elas eram apenas duas no território nacional (Rio de Janeiro e São Paulo), passam a cinco na década de 1970, e chegam a 10 nos anos 1980 (SANTOS, 1993; SANTOS e SILVEIRA, 2001). As metrópoles são também um fenômeno novo e importante para entendermos o território pois:

a) elas entretêm, na verdade, vários municípios em áreas contíguas, aumentando as necessidades de investimentos em órgãos de planejamento, em redes de transportes metropolitanos (trens urbanos, metrô, ônibus municipais e intermunicipais), entre outras infra-estruturas típicas de grandes aglomerações (SOUZA, 1988); e

b) nas metrópoles é que a riqueza e a pobreza também passam a conviver cada vez mais próximas, com repercussões em diversos aspectos do cotidiano urbano (SILVEIRA, 2004; 2005); nas atividades comerciais (o surgimento dos "camelôs", ao lado dos grandes "shopping centers"); nas atividades de transformação (surgem tanto 
grandes indústrias modernas, quanto uma dispersão enorme de pequenas fabriquetas para os consumos básicos das populações de menor renda ${ }^{54}$ ); na prestação de serviços de uma maneira geral (escolas públicas, privadas, universidades, postos de saúde, hospitais com serviços e equipamentos "raros" 55 etc.).

Este quadro, ainda que sumariamente descrito, nos dá uma idéia de como o tamanho e a distribuição da população têm repercussões diretas na organização social e econômica do espaço geográfico. O que se procurou destacar é que o incremento da vida urbana do território aumenta todos os tipos de consumo possíveis: consumos dos setores empresariais (por insumos, financiamentos), estatais (consumos materiais e imateriais para a prestação eficiente dos serviços urbanos), e ainda os consumos individuais e familiares. Nas palavras do geógrafo Milton Santos, difundem-se novas formas de consumo consumptivos como produtivos (1993:50).

Se há uma nova geografia urbana, há também uma nova geografia agrícola em gestação no território. Além de ser um elemento decisivo para o incremento do próprio processo de urbanização, a profusão de novos objetos técnicos no meio rural cria automaticamente novas necessidades de crédito para os sistemas de ação agrícolas, como veremos.

\subsection{A creditização do espaço agrícola}

Dadas as novas técnicas de produção no campo, fruto da utilização de uma quantidade maior e mais diversificada de objetos e sistemas técnicos (maquinário, insumos agrícolas, mão-de-obra especializada etc.), parece-nos oportuno utilizar o termo "regiões agrícolas", ao invés de "regiões rurais" (SANTOS, 1993) para

\footnotetext{
${ }^{54}$ Para uma análise detalhada da coexistência de grandes e pequenas empresas no território brasileiro (no caso, relacionada ao mercado de refrigerantes), ver Flávia Grimm (2002). Edison Bicudo Jr. (2006), por seu turno, traz uma análise dos circuitos espaciais da indústria farmacêutica. Marina Montenegro (2006) analisa ainda a evolução do chamado "comércio ambulante" (camelôs) na cidade de São Paulo.

${ }^{55}$ Sobre a distinção entre serviços comuns e raros, ver o importante texto de Jean Labasse e Michel Rochefort (1965). Para os autores (LABASSE e ROCHEFORT, 1965:57), um "serviço raro" seria aquele vinculado a uma "extrema especialização", como é o caso do comércio de objetos de arte, salas de concerto para música clássica, hospitais com serviços de neurocirurgia, entre outros.
} 
entendermos os novos usos do território passíveis de serem realizados, a partir da introdução desses sistemas técnicos no campo. Tanto há cidades que se voltam para seus respectivos entornos agrícolas, quanto há regiões agrícolas que se organizam para o abastecimento de seus respectivos centros urbanos. Esta é uma nova realidade, diferente daquela existente antes da expansão do meio técnicocientífico no interior do território brasileiro (SANTOS, 1993).

Wladimir Lênin $(1907,1974)$ já notara em seu clássico estudo sobre a difusão do capitalismo na Rússia como passa a funcionar o meio agrícola em países que conhecem uma modernização de seus aparatos produtivos. Simultaneamente, vemos um aumento das quantidades colhidas (com mais rapidez que a própria área plantada), uma diminuição da população agrícola necessária para manter o sistema de ações produtivo, assim como uma elevação da "transformação técnica dos produtos agrícolas"(LENIN, 1907, 1974:235). Estes são alguns dos indicativos deste processo que em geografia pode ser entendido como a "cientifização da agricultura" (SANTOS, 1993; ELIAS, 1996; SILVEIRA, 1996).

Também o geógrafo Daniel Faucher (1953) atenta para o que chamou de "novos tipos de cultivo" permitidos - e mesmo catalisados - pela introdução de objetos técnicos nos processos agrícolas. Dado o aumento da demanda por produtos voltados para usos industriais, cada vez mais os cultivos tradicionais dão espaço para plantações que sirvam de insumo para processos de transformação dos mais variados tipos: "plantas têxteis" (como o algodão); oleaginosas; "plantas açucareiras", entre outras. Assim, cultivos voltados para as necessidades tradicionais das regiões agrícolas dos países são cada vez menos priorizados (FAUCHER, 1953:269 e seguintes).

Um índice confiável para entendermos melhor esta "difusão espacial de inovações" (HÄGERSTRAND, 1953) ou "expansão do meio técnico-científico" no meio agrícola (SANTOS, 1993) é dado, segundo a geógrafa Soraia Ramos (2001), pela área artificialmente irrigada do território. Segundo a autora, apesar dos projetos 
deste tipo terem sido tentados já no início do século XX (de forma pontual), é a partir dos governos militares instalados em 1964 que a irrigação se torna uma política sistematizada, fruto da necessidade de desenvolvimento do espaço agrícola nacional em moldes "técnico-científicos". A tabela a seguir nos dá uma idéia mais próxima deste movimento do território:

Tabela 7: Brasil: Evolução da Área Irrigada no Território Brasileiro, por Grandes Regiões (em ha) (1960-1985)

\begin{tabular}{|l|r|r|r|r|r|r|}
\hline & \multicolumn{2}{|c|}{$\mathbf{1 9 6 0}$} & \multicolumn{2}{c|}{$\mathbf{1 9 7 0}$} & \multicolumn{1}{c|}{$\mathbf{1 9 8 5}$} \\
\hline & \multicolumn{1}{|c|}{ Total } & \multicolumn{1}{c|}{$\%$} & \multicolumn{1}{c|}{ Total } & \multicolumn{1}{c|}{$\%$} & \multicolumn{1}{c|}{ Total } & \multicolumn{1}{c|}{$\%$} \\
\hline Norte & 67 & 0,01 & 5.420 & 1,0 & 43.242 & 2,20 \\
\hline Nordeste & 52.772 & 11,43 & 115.971 & 14,0 & 366.831 & 18,71 \\
\hline $\begin{array}{l}\text { Centro- } \\
\text { Oeste }\end{array}$ & 2.027 & 0,44 & 14.579 & 2,0 & 63.220 & 3,22 \\
\hline Sudeste & 116.285 & 25,19 & 185.183 & 23,0 & 599.564 & 30,59 \\
\hline Sul & 290.399 & 63,00 & 474.663 & 60,0 & 886.963 & 45,25 \\
\hline BRASIL & 461.100 & 100,00 & 795.815 & 100,0 & 1.959 .824 & 100,00 \\
\hline
\end{tabular}

Fonte: Censos Agropecuários (IBGE) - Adaptado de RAMOS, Soraia (2001:378)

Como podemos observar na tabela 7, a partir da década de 1960, houve uma aceleração da utilização dos sistemas técnicos voltados para a irrigação dos cultivos no território: de 1960 para 1970, a área irrigada na Região Norte cresce quase 100 vezes. No Centro-Oeste, este índice é também expressivo, já que ali o uso destes modernos sistemas aumenta em cerca de $619 \%$. No Nordeste, sua utilização é praticamente triplicada, e nas regiões Sul e Sudeste (onde já havia uma utilização mais freqüente de métodos agrícolas modernos), as quantidades quase dobram.

Este é, portanto, um índice de modernização do espaço agrícola brasileiro, que permite ver como novos sistemas de objetos se instalam nas áreas produtivas, aumentando os índices de produtividade das regiões agrícolas. Esta incorporação de ciência e técnica nos circuitos gera mais excedentes nas regiões, fato que terá um duplo impacto no sistema bancário: a) serão necessários cada vez mais recursos creditícios para o financiamento e a manutenção dessas infra-estruturas; e b) cada vez mais será necessário também no interior do país a abertura de agências, para a realização dos depósitos desses excedentes dos produtores agrícolas. 
O mesmo raciocínio pode ser feito para outros importantes sistemas técnicos que vêm sendo introduzidos com força no espaço agrícola brasileiro, desde meados da década de 1960: os tratores e implementos agrícolas. Vejamos a tabela a seguir, que nos dá a evolução da área cultivada, o número de tratores existentes em território nacional e o "índice de tratorização" do país (relação entre a área de cultivo/número de tratores):

Tabela 8: Brasil: Evolução da Frota de Tratores e do Índice de Tratorização do Território Brasileiro (1960-1980)

\begin{tabular}{|l|r|r|r|r|r|}
\hline & \multicolumn{1}{|c|}{$\mathbf{1 9 6 0}$} & $\mathbf{1 9 6 5}$ & \multicolumn{1}{c|}{$\mathbf{1 9 7 0}$} & \multicolumn{1}{c|}{$\mathbf{1 9 7 5}$} & \multicolumn{1}{c|}{$\mathbf{1 9 8 0}$} \\
\hline $\begin{array}{l}\text { Área de Cultivo (em mil } \\
\text { ha) }\end{array}$ & 25.673 & 31.637 & 34.912 & 41.811 & 47.641 \\
\hline Número de Tratores & 62.684 & 76.691 & 97.160 & 273.852 & 480.340 \\
\hline Índice de Tratorização & 410 & 413 & 359 & 153 & 99 \\
\hline
\end{tabular}

Fonte: Anfavea e Censos Agropecuários, Vários Anos; Adaptado de COGO, Carlos (2006) extraído de http://www.agr.unicamp.br/ em 03/10/2006

Podemos notar também que, a partir da década de 1970, cresce substancialmente o número de tratores utilizados no meio agrícola brasileiro assim como, por conseqüência, aumenta também a quantidade de tratores utilizados por hectare ${ }^{56}$. A modernização do espaço agrícola, portanto, é um processo decorrente desta complexificação dos insumos utilizados na agricultura, que altera ainda os sistemas de ações que cuidam dos cultivos. Como nos lembra a geógrafa Rosa Ester Rossini (1988:123), "com o processo de modernização que ocorreu no período, a terra foi reduzida à sua condição de meio de produção, e expulsou o trabalhador do campo"; este é também um dos resultados desta racionalização do espaço agrícola brasileiro.

\footnotetext{
${ }^{56}$ Duas ilações podem ser feitas a partir destes dados: a) com a introdução dos tratores no meio agrícola, podemos dizer que diminui a velocidade de expansão da área agricultável, já que aumentam os índices de produtividade das áreas já cultivadas; ocorre, como demonstraram Milton Santos e María Laura Silveira (2001:132), uma diminuição da "arena de produção", com aumento da "área de produção". Nas palavras desses autores: "Estradas, silos, frigoríficos, portos com terminais de uso exclusivo e tantos outros objetos indicam a força dos capitais fixos no território. Mas esse arranjo de objetos não funciona sem um acréscimo contínuo de máquinas de plantio e colheita, tratores, sementes híbridas e fertilizantes, isto é, um capital constante (orgânico) que, por sua vez, precisa de energia e informação, que são também normas (calendários agrícolas, instrutivos de utilização dos produtos etc.). A provisão de todos esses insumos e a presença dos especialistas para realizar um trabalho extremamente dividido aumenta a necessidade de movimento. Cresce a espessura dos fluxos de produtos, insumos, pessoas, ordens e, sobretudo, dinheiro" (SANTOS e SILVEIRA, 2001:132).
} 
Esse processo de racionalização, que Max Weber denominaria como um enorme "desencantamento do mundo" diz respeito principalmente ao aumento da racionalidade técnica, imposta aos ritmos de trabalho nas áreas agrícolas. As colheitas - e seu sucesso - passam a ser creditadas a ações calculadas, planejadas intencionalmente, e não mais aos desígnios "encantados", "mágicos" dos elementos climáticos e sazonais dos lugares; este é um dado iniciado com força no período que por ora nos detemos.

Mas o que importa destacar com mais ênfase, para efeito de nosso estudo, são as conseqüências deste acréscimo de novos sistemas de objetos e de ações em sua relação com as novas necessidades de financiamento. Como lembram Milton Santos e María Laura Silveira (2001), as áreas cultivadas a partir deste território mais integrado e cientifizado exigem também somas maiores de recursos financeiros para que as estruturas se mantenham funcionando:

“(...) assim, a economia e o território não se organizam nem funcionam sem grandes somas de dinheiro nas suas formas de crédito, empréstimos, numerário vivo, financiamentos, hipotecas, commodities, seguros e tantos outros instrumentos. Cria-se dessa forma uma dependência do sistema financeiro, que acaba invadindo todas as etapas da produção em sentido amplo, pois todas "precisam" dele e todas constituem modos de acumulação de mais-valia." (SANTOS e SILVEIRA, 2001:132).

Os novos conteúdos agrícolas do território vão assim chamar a necessidade de novas operações financeiras, por parte de praticamente todos os atores envolvidos com as atividades agrícolas modernas. Maria da Conceição Tavares (1978:133) lembra também que na agricultura que se inicia a partir dos anos 1960, "sempre que eram utilizadas técnicas mais intensivas que exigissem insumos nãoconvencionais ou equipamentos, a demanda adicional de recursos se exercia sobre as mesmas fontes supridoras de crédito" (...),"em particular o Banco do Brasil, que possui a maior rede de agências de crédito agrícola".

A essa expansão do fenômeno do crédito para além das áreas urbanas do território, incorporando as finanças nos circuitos de produção agrícola, o geógrafo 
Milton Santos (1993:42 e ss.) qualificou de "creditização do território". A própria difusão do assalariamento, assim como as novas necessidades de aquisição de maquinário e insumos de todos os tipos trazem a "necessidade maior de capital adiantado, o que vai explicar a enorme expansão do sistema bancário"(SANTOS, op. cit.42) no território. Daí sua creditização.

Este fenômeno pode ser melhor entendido quando analisamos os índices de acesso ao crédito rural por parte dos produtores agrícolas neste período, que crescem em proporções significativas. Para o intervalo 1969-1976, o crescimento do crédito é de cerca de 23,8\% ao ano, "várias vezes superior ao crescimento real do produto agrícola, situado em torno de 5,5\% a.a."(DELGADO, 1985: 79).

Do ano de 1969 até o ano de 1980, a evolução da concessão de crédito rural assim se comportou no território brasileiro:

Tabela 9: Brasil: Evolução do Crédito Rural Concedido e Outros Indicadores (em milhões de cruzeiros de 1977) (1969-1890)

\begin{tabular}{|l|r|r|r|r|r|}
\hline & 1969 & 1972 & 1975 & 1978 & 1980 \\
\hline $\begin{array}{l}\text { Crédito de } \\
\text { custeio }\end{array}$ & $25.873,8$ & $29.610,7$ & $79.480,2$ & $80.437,0$ & $113.720,9$ \\
\hline $\begin{array}{l}\text { Crédito de } \\
\text { investimento }\end{array}$ & $15.649,8$ & $23.522,7$ & $56.683,5$ & $42.122,4$ & $37.700,9$ \\
\hline $\begin{array}{l}\text { Crédito } \\
\text { comercial }\end{array}$ & $14.176,8$ & $24.384,5$ & $45.172,5$ & $46.108,5$ & $49.558,9$ \\
\hline $\begin{array}{l}\text { Crédito rural } \\
\text { total (índice } \\
\text { de valor real) }\end{array}$ & 100,0 & 170,49 & 433,76 & 403,45 & 481,11 \\
\hline
\end{tabular}

Fonte: Elaboração própria a partir de DELGADO (1985:81).

As informações da tabela 9 nos permitem concluir que aumenta sensivelmente a financeirização dos circuitos agrícolas, com aceleração visível do processo na passagem do ano de 1972 para o ano de 1975. Como demonstra o "índice de valor real" (que correspondia a 100 no início da contagem da tabela), saltamos de um valor próximo aos 170 em 1972 para nada menos que 433 no ano de 1975 . 
Os processos acima descritos, destarte, nos ajudam a compreender como a alteração dos conteúdos agrícolas do território é também responsável por novas necessidades de crédito. Estas novas necessidades, por seu turno, viriam a requerer também uma nova organização do sistema bancário nacional, como veremos no item 6.2.

Concomitantemente ao processo de urbanização e de creditização do meio agrícola, crescem também as necessidades de integração das diferentes regiões produtivas, que se formavam a partir de uma nova divisão territorial do trabalho. Ungidos pela "Doutrina da Segurança Nacional" (COUTO E SILVA, [1967]1981), os diversos sistemas de ação do Executivo Federal imprimem políticas públicas de integração e desenvolvimento do território, fundadas principalmente na modernização dos sistemas de movimento e de telecomunicações, além da expansão de certos sistemas de engenharia (industriais, energéticos e de geração de tecnologia) nacionais.

\subsection{A construção dos grandes sistemas de engenharia e a integração nacional}

A tomada do poder por parte da elite militar em 1964 instala um sistema de ações no governo federal bastante centralizado, tanto no que diz respeito ao controle dos processos políticos, quanto do manejo das finanças públicas do País. Essa centralização - com o concomitante alijamento da participação popular nos processos decisórios da nação - é que permitiu um dinâmico processo de acumulação capitalista, financiado em grande parte pelos recursos fiscais concentrados na esfera federal do Estado (OLIVEIRA, 1991; 1995).

Nessa fase é que são criadas, segundo Wilson Suzigan (1976: 89 e ss.), o maior número de empresas estatais, em comparação com os demais períodos de nossa história republicana. As empresas mais importantes foram criadas justamente naqueles ramos de atividade que demandavam uma escala de atuação que o empresariado nacional não possuía. São exemplos destes ramos: 
a) sistemas de produção e distribuição de energia;

b) infra-estruturas de transporte;

c) infra-estruturas de comunicação;

d) indústria de transformação (principalmente as chamadas "indústrias de base", como a siderurgia, petroquímica, indústria de fertilizantes e da celulose, entre outras);

e) serviços diversos (processamento de dados, comércio exterior, distribuiç̧ão de derivados de petróleo);

f) serviços públicos em geral (saúde, educação, infra-estruturas urbanas);

g) serviços financeiros (como veremos no capítulo 7);

No que diz respeito às infra-estruturas de energia, em primeiro lugar era necessário centralizar o comando dos sistemas de engenharia sob os auspícios da Eletrobrás (criada em 1961, como mencionamos). As duas principais infra-estruturas de produção de energia - a CHESF e FURNAS - tornam-se em definitivo subsidiárias desta holding federal, e as empresas que ainda pertenciam à empresa norteamericana Amforp (American \& Foreign Power Company) são nacionalizadas ${ }^{57}$.

Conseguida a unificação do ponto de vista organizacional (isto é, do funcionamento do sistema de ações), restava realizar a uniformização dos sistemas técnicos de geração, em algumas regiões do país. Para isso, conforme descreve também Antonio Dias Leite (1997), algumas importantes medidas são tomadas, como por exemplo:

a) no Nordeste, a unificação é conseguida através da absorção pela CHESF da Usina de Boa Esperança (Cohebe), e de seu respectivo sistema de transmissão, "construídos de forma isolada para atender exclusivamente ao Maranhão e ao Piauí" (LEITE, 1997:160);

b) no Sul, sob o comando regional da Eletrosul (criada em 1968), foram incorporadas ao sub-sistema local as usinas de geração térmica do Rio Grande do Sul e de Santa Catarina; assim como foi somada a esta rede a Hidrelétrica de Passo Fundo, em 1971.

57 As últimas empresas que ainda estariam sob controle da Amforp (já que essa empresa possuía filiais nos estados de São Paulo, Rio Grande do Sul e Pernambuco), passam paulatinamente ao controle dos estados da federação em que se situavam, vindo também compor o sistema Eletrobrás. (LEITE, 1997). Vale lembrar que a partir da unificação das geradoras em torno da Eletrobrás, surge a "tendência de adoção da força hídrica"(ANTAS Jr., 2005:199) para compor a matriz energética nacional. 
c) Na Região Norte do país, após a constituição da Eletronorte (em 1973, com sede em Brasília), vários projetos são pensados e executados na região amazônica, "para o suprimento de energia elétrica aos pólos isolados de consumo"(LEITE, 1997:160); nesta parte do país, portanto, mais do que unificar os sistemas técnicos, era necessário mesmo expandir os sistemas de engenharia, de forma a criar as condições para a ocupação produtiva da região.

Esta era, portanto, a nova realidade do território no que diz respeito à integração dos sistemas de produção e distribuição de energia. Seria suficiente tocarmos nos principais aspectos dessa unificação descrita acima, não fosse a magnitude de outro fixo geográfico construído no mesmo período, com repercussões para praticamente todo o uso produtivo do território à época: a construção da Hidrelétrica de Itaipu ${ }^{58}$.

O projeto dessa hidrelétrica visava suprir com energia farta e relativamente barata as regiões Sul e Sudeste do país (a região concentrada, como vimos), que possuíam já um uso industrial do território bastante dinâmico. Dado esse uso industrial, gerou-se uma necessidade de suprimento bem maior que nas demais regiões do país, daí a construção de Itaipu ${ }^{59}$.

\footnotetext{
${ }^{58}$ A construção da Usina é decidida no ano de 1966, num projeto conjunto entre os governos brasileiro e paraguaio, através da Ata das Cataratas; além de um forte apelo para a resolução de certos "ressentimentos originados na Guerra do Paraguai" (LEITE, 1997:162), a construção desse macrossistema técnico dirimiria também querelas relativas à demarcação das fronteiras entre os dois países na região, já que o enorme lago formado inundaria a área sob litígio.

${ }^{59}$ As obras para a construção da barragem iniciam-se no ano de 1975, e sua operação de fato se daria somente no ano de 1983 (sendo que a última unidade geradora seria instalada em 1992). Com capacidade para gerar $12.600 \mathrm{Mw}$, o complexo Itaipu pareceu digno de destaque por três principais motivos: a) constituise num macrossistema técnico instalado nesta região do território brasileiro, para responder às demandas de um processo de industrialização robusto iniciado no pós-1964; b) é também um exemplo de um sistema de engenharia que já nasce integrado para a geração/distribuição de energia no país, ao contrário dos sistemas pulverizados, comuns antes do período técnico-científico do território; c) é um macrossistema técnico que requereu para sua construção uma quantidade enorme de capitais; daí ser este novo elemento do território um indicativo da necessidade de engrandecimento também do sistema financeiro nacional. Vale lembrar que sua construção tem também relação direta com a disponibilidade de capitais financeiros internacionais abundantes para este tipo de investimento. Como nos lembra María Laura Silveira, há um esforço dos Estados de boa parte dos países do Terceiro Mundo em dotar seus respectivos territórios de sistemas de engenharia que aumentem a produtividade dos capitais transnacionais em expansão. Analisando o caso argentino, lembra a autora (SILVEIRA, 1999:102) que "Quando o Estado reserva para si uma parcela da organização técnica e política da produção energética, ele está complementando a ação das empresas transnacionais no território argentino. Os governos militares criaram empresas e organizações para desenvolver projetos energéticos, obter créditos internacionais e unificar o comando das redes técnicas". Para uma análise ainda mais atualizada da organização do território argentino, ver María Laura Silveira (2003a).
} 
Concomitantemente ao desenvolvimento de uma nova base de geração/distribuição de energia, é também montada uma nova "equação da circulação" no território, para usar o conceito do general Mario Travassos (1942). São incorporadas ao espaço nacional infra-estruturas de transporte que reforçam a efetiva integração física da nação. Uma das principais mudanças dessa "equação" é justamente o uso mais banalizado do sistema de movimento rodoviário, na articulação das cidades e das regiões brasileiras.

A rede rodoviária nacional - uma rede-suporte que indica bem a expansão do meio técnico-científico no território - "passa de 302.147 quilômetros em 1952 para 1.657.769 quilômetros em 1995, sendo seu maior crescimento na década de 1970", lembram-nos Milton Santos e María Laura Silveira (2001:65).

É o geógrafo Marcos Xavier (2001) que assevera ainda que desde ao menos a década de 1960 o território brasileiro vem se integrando em função do acréscimo desta capilarizada rede, que são as rodovias brasileiras.

Tabela 10: Brasil: Evolução da Rede Rodoviária Pavimentada Segundo as Grandes Regiões em km (1964-1991)

\begin{tabular}{|l|r|r|r|r|}
\hline Região & \multicolumn{1}{|c|}{1964} & \multicolumn{1}{|c|}{$\mathbf{1 9 7 1}$} & \multicolumn{1}{|c|}{$\mathbf{1 9 8 1}$} & \multicolumn{1}{|c|}{$\mathbf{1 9 9 1}$} \\
\hline Norte & 988 & 1.993 & 4.500 & 8.378 \\
\hline Nordeste & 3.284 & 13.340 & 25.602 & 40.506 \\
\hline Centro-Oeste & 723 & 2.701 & 7.793 & 16.801 \\
\hline Sudeste & 11.207 & 29.715 & 32.793 & 51.478 \\
\hline Sul & 2.528 & 8.871 & 18.765 & 26.776 \\
\hline TOTAL & 18.730 & 56.619 & 89.449 & 143.703 \\
\hline
\end{tabular}

Fonte: Anuário Estatístico do IBGE; adaptado de XAVIER (2001:334)

Desta tabela podemos depreender que há um aumento bastante significativo da rede rodoviária pavimentada entre os anos de 1964 e 1991. Em termos nacionais, a rede aumenta em nada menos que 202\% (1964-1971); depois, 58\% entre 1971 e 1981, para chegarmos a um acréscimo de $60 \%$ nas estradas pavimentadas entre os anos de 1981 e 1991. Daí podermos inferir ao menos duas conseqüências para a vida de relações do território: 
a) houve uma possibilidade de aumento da circulação material, já que a ampliação desta rede-suporte permite uma integração capilarizada (dado o expressivo alcance da rede) dos diferentes sistemas de ações produtivos instalados no território;

b) este aumento generalizado da malha rodoviária em todo o território nacional é ainda mais contundente nas regiões de ocupação mais rarafeita do território (como era o caso do Centro-Oeste e do Norte, antes de 1964); no Centro-Oeste, a rede pavimentada cresce em cerca de $2.223 \%$ para o período todo da tabela (1964-1991); já no Norte do país, o acréscimo é de cerca de $747 \%$, para o mesmo período.

Inicia-se a partir da década de 1960 uma clara aceleração na difusão do uso do sistema de movimento rodoviário no território, período em que a urbanização e a integração do espaço nacional passam a demandar uma vida de relações mais intensa dentro e entre as cidades brasileiras (BARAT, 1978:243-265) ${ }^{60}$.

Com relação ao sistema de movimento ferroviário (a alternativa mais adequada para o transporte de cargas pesadas, na longa distância), houve grande esforço por parte do Governo Federal de fazer deste sistema um elemento dinâmico do território. A revitalização da Rede Ferroviária Federal (RFFSA, que havia sido criada em 1957) é um exemplo claro disto (BARAT, 1978). Principalmente a partir do início da década de 1970, como nos lembra Carlos Lessa, a grande novidade para os transportes

\footnotetext{
${ }^{60}$ Cabe ressaltar que a rodoviação conheceu esse sucesso histórico ainda por dois motivos: a) pelas próprias características intrínsecas deste modal; e b) pela relação direta com o período de multinacionalização da indústria brasileira. Com relação às características próprias do modal rodoviário, podemos dizer que ele é, de longe, a forma mais flexível para o transporte de passageiros e cargas. É mais flexível pois não necessita de infra-estruturas e equipamentos de suporte muito sofisticados (como é o caso da aeronavegação) nem muito rígidos (como é o caso das linhas de trem). Permite o chamado "transporte porta a porta", tanto para o deslocamento de pessoas, mas principalmente para o escoamento de mercadorias (MERLIN, 1991). A banalização de sua rede-suporte permitiu utilizar (e mesmo melhorar a qualidade) de caminhos existentes desde o período pré-técnico do território, além de catalisar a criação de caminhos novos, que incorporam áreas menos densamente ocupadas no interior do território. Com relação ao período de multinacionalização da indústria brasileira, podemos lembrar que boa parte do dinamismo que as empresas multinacionais trouxeram ao sistema produtivo brasileiro se deu através da construção de um parque automobilístico pelas montadoras de carros estrangeiras (GM, Volkswagen, Ford etc.). Instalados estes novos atores no território, parte das políticas governamentais passa a adequar as infra-estruturas do território para o desenvolvimento da rodoviação, com a criação de autarquias como o DNER, DERSA, construção de estradas etc. Essa adequação das políticas públicas se dá em função também dos poderosos lobbies que as multinacionais passam a exercer sobre os sistemas de ação do governo federal.
} 
“(...) foi o Programa de Desenvolvimento Ferroviário. Suas metas iniciais previam triplicar as $\mathrm{t} / \mathrm{km}$ transportadas entre 1973 e 1980 . Para tal indicava-se a construção de $3.800 \mathrm{~km}$ de novas linhas, e variantes, melhoramentos em $10.800 \mathrm{~km}$ de linhas existentes, mudança de bitola em $3.200 \mathrm{~km}$ e aquisição de 25.000 vagões e 300 locomotivas"(LESSA, 1988, 1998:129)

Ainda que os esforços para a retomada do dinamismo do sistema de ações ferroviário tenha sido uma das tônicas da preocupação federal nos anos 1970, as iniciativas não lograram um resultado satisfatório, dada a estrutura eminentemente extravertida e desarticulada da rede. Esta topologia (herdada do período técnico do território, como vimos no capítulo 2) não permitia a interiorização/integração preconizada pelo novo ethos do governo federal. Alterar esta rede-suporte demandaria uma quantidade de recursos vultosos, cujo investimento possivelmente inviabilizaria outros programas em plano ${ }^{61}$.

Por fim, mas não menos importante, pareceu-nos necessário também dar um destaque ao sistema de movimento típico do período técnico-científico que se gestava desde o final da Segunda Guerra Mundial: o sistema de movimento aeroviário. De maneira esquemática, podemos dizer que estes fluxos passam a ser essenciais à nova estruturação do território pois conforme demonstram Cordeiro e Bernardes (1994), o sistema de movimento aeroviário é aquele que transporta cargas mais sofisticadas (produtos de alto valor agregado), e passageiros do chamado "setor quaternário" (TOMELIN, 1988) da economia ${ }^{62}$ : os diretores e altos funcionários de empresas, políticos etc. Daí que a aeroviação é o modal que viabiliza a complementaridade material entre as ordens e informações de comando do território, no ritmo e na velocidade que a nova divisão territorial do trabalho requeria.

${ }^{61}$ Com relação ainda à topologia do sistema de movimento ferroviário, vale destacar que desde a década de 1970, ela ajuda a cumprir dois papéis principais no uso do território brasileiro: a) serve para o deslocamento nas metrópoles brasileiras - principalmente nas regiões metropolitanas de São Paulo e Rio de Janeiro - de populações de baixa renda, através das companhias metropolitanas de transporte ferroviário de cada região; e b) serve também (com níveis de eficiência muitas vezes superiores às redes do $1^{\circ}$. Mundo) ao escoamento de commodities das empresas de mineração (principalmente as redes sob controle da Companhia Vale do Rio Doce - CVRD) e dos empresários do agronegócio, sistemas de ação voltados ao exterior. Vale lembrar que esta estrutura assim montada, reforça o modelo extravertido do uso do território, herdado ainda dos períodos colonial e imperial (pré-técnicos) do território brasileiro.

62 O conceito de "setor quaternário" foi cunhado por Jean Gottmann em seu livro Megalópolis, de 1961. Este setor seria uma evolução do que Michel Rochefort e Jean Labasse (1965) denominaram de "terciário superior". O quaternário, segundo a definição aqui utilizada, estaria ligado eminentemente aos seguintes "poderes": "poder do terciário público: político e administrativo; poder de produção, representado essencialmente pelas sedes sociais das empresas industriais; poder financeiro, representado pelas organizações bancárias e pelas sociedades financeiras"(ROCHEFORT, 1975, apud TOMELIN, 1988:72). 
Com a consolidação dos vôos regulares entre as principais cidades do território, foi permitido o transporte com a freqüência e a velocidade necessárias para a ligação das nove Regiões Metropolitanas brasileiras - somadas as cidades de Brasília e Manaus (CORDEIRO e BERNARDES, 1994:286). Esses fluxos possibilitam uma nova complementaridade regional no país, num território que já vinha sendo integrado pelas vias terrestres através dos demais sistemas de movimento. Um exemplo bastante concreto das novas possibilidades de uso do território abertas pelo sistema de movimento aeroviário é o próprio funcionamento da cidade de Brasília. A cidade, que controla atividades do setor quaternário importantíssimas para a nação, teve seu desenvolvimento diretamente ligado à aviação; certamente teria sido impossível instalar ali a capital política do país sem o sistema de movimento aeroviário desenvolvido, já que somente através dele é que se torna efetivamente viável o deslocamento de políticos, empresários, e funcionários das burocracias federal, estadual e municipal para a capital do Brasil ${ }^{63}$.

Este é um quadro sucinto do sistema de movimento aeroviário, que nos dá uma idéia de como a expansão do meio técnico-científico no interior do território vai exigindo dos sistemas de ação do Estado e das grandes empresas a construção de uma série de sistemas de objetos que permitissem a integração do território também por via aérea. Este modal pode ser também considerado como um dos primeiros elementos do território que vai pedir o acréscimo de objetos informacionais ${ }^{64}$ em seus sistemas técnicos.

\footnotetext{
${ }^{63}$ Neste período desenvolvem-se ainda os fluxos de taxi aéreo no território. Através dos serviços de taxi aéreo foi possibilitado o deslocamento de pessoal técnico, políticos e empresários para as fronteiras agrícolas do território em expansão. Também os pólos de desenvolvimento agrominerais (ligados aos projetos de colonização da Amazônia, como o Projeto Grande Carajás) foram dinamizados em grande parte pela utilização do subsistema de movimento do taxi aéreo.

${ }^{64}$ Neste período começam a ser introduzidos sistemas técnicos demandadores desta nova variável-chave do período: a informação. Além de técnico-científicos, portanto, os objetos e as ações mais modernas passam a ser cada vez mais "informacionais". Podemos dizer que um objeto é também informacional quando "de um lado, é chamado a produzir um trabalho preciso - que é uma informação - e, de outro lado, funciona a partir de informações"(SANTOS, 1996:171). E prossegue o autor: "Na era cibernética que é a nossa, um objeto pode transmitir informação a outro objeto. Os autômatos asseguram uma cadeia causal eficaz, mediante um sistema de objetos que transmitem informação uns aos outros, ainda que o homem não esteja ausente, ao menos no início do processo"(SANTOS, op. cit::171-172). A instalação da Zona Franca de Manaus, assim como a criação da Embraer são exemplos de atividades e de políticas públicas que vão acrescentar processos e produtos cada vez mais intensivos em "Informação" nos circuitos produtivos do território.
} 


\subsection{Os novos conteúdos industriais do território: a indústria pesada}

Com a integração física do espaço brasileiro, e a consolidação de um mercado interno mais coeso, é permitido a partir das décadas de 1960 e 1970 um novo processo de substituição de importações (TAVARES, 1978), em que outros bens industriais são passíveis de serem produzidos por empresas aqui instaladas. Não só bens de consumo não-duráveis (como alimentos), mas também bens duráveis (eletrodomésticos, automóveis), bens intermediários (insumos industriais de toda sorte) e bens de capital (necessários à chamada "industrialização pesada" do território) são objetos que passam a ser produzidos internamente, a partir dessa base técnica mais integrada e diversificada.

Ao mesmo tempo causa e conseqüência das novas medidas institucionais implementadas pelo governo militar a partir do ano de 1964, o país conhece um surto de crescimento industrial a partir de 1967, que ficou conhecido como "milagre brasileiro". Na base deste crescimento, do ponto de vista dos conteúdos industriais do território, estava a produção de bens de consumo duráveis (BARROS DE CASTRO e SOUZA, 1985, 2004), baseada mormente na indústria automobilística. Esta, por sua vez, tem a raiz do seu "sucesso" histórico na própria configuração territorial que se transformava: eram necessários cada vez mais automóveis para possibilitar os fluxos de bens e mercadorias por todo o território, como era também necessária uma frota de veículos cada vez maior nos grandes centros urbanos em formação.

Estes avanços no processo de industrialização e de integração do território brasileiro se mostrariam bastante dinâmicos até ao menos o ano de 1973, quando o evento conhecido como "choque do petróleo" vem alterar a "liquidez do mercado internacional de divisas" (SALAMA, 1984). A partir deste evento, consolida-se um "mercado internacional de capitais"(SANTOS FILHO, 1993:51 e 
ss.), e tornam-se mais caros os empréstimos externos que financiavam parte significativa do crescimento dos países do Terceiro Mundo, aí incluindo o Brasil ${ }^{65}$.

No ano de 1974 (através do /I PND) o Governo Federal opta por manter um processo de endividamento externo, sob o pretexto de continuar o processo de consolidação de uma nova base técnico-científica no território brasileiro. A economia brasileira, para usar a metáfora de Antonio Barros de Castro, entra num período de "marcha forçada" (BARROS DE CASTRO e SOUZA, 1985, 2004), isto é: mantém-se a "marcha" do processo de endividamento (principalmente através do Estado nacional, mas também pelo sistema bancário aqui instalado), sob a tutela "forçada" de um governo militar com controle rígido sobre os processos políticos do país.

Data deste período o desenvolvimento das indústrias de bens de consumo duráveis, mas as políticas "setoriais" se dirigiriam principalmente para o que se convencionou chamar de "indústria pesada"; o Estado nacional impulsiona o surgimento/crescimento de atividades industriais mais complexas, nas áreas em que a iniciativa privada não tinha nem escala nem interesse suficiente para assumir as empreitadas, como frisado. Poderíamos elencar assim as áreas em que o Governo Federal interveio de maneira mais sensível (direta ou indiretamente):

1) indústrias de insumos básicos: mineração, siderurgia, química e petroquímica, fertilizantes e petróleo;

2) serviços industriais de utilidade pública: energia elétrica, gás, água e esgoto;

3) outros serviços públicos: armazenagem, transportes e comunicações (SUZIGAN, 1975:126).

A partir deste momento, portanto, há uma clara mudança no "padrão de industrialização” brasileira, descrita por Carlos Lessa:

\footnotetext{
65 A partir de 1973, portanto, o aumento do custo do dinheiro internacional colocou ao Governo Federal basicamente duas opções de política de desenvolvimento: a) poderia ser interrompido o processo de "crescimento com endividamento" iniciado, com conseqüências graves para o funcionamento sistêmico que se instalava nas infra-estruturas, boa parte delas ainda em construção; ou b) era dada continuidade a "um novo bloco de investimentos", permitido basicamente por novos empréstimos externos, malgrado o ambiente externo mais desfavorável (BARROS DE CASTRO e SOUZA, 1985, 2004).
} 
"A mudança do Padrão de Industrialização dispunha no coração da Estratégia uma ampliação da oferta de insumos básicos perseguindo no principal a autosuficiência nacional para 1980. Os investimentos destes setores criariam uma procura ampliada de máquinas e equipamentos. Esta demanda orientada crescentemente para o mercado interno constituiria um horizonte firme e programado para a expansão, diversificação e a sofisticação tecnológica da indústria nacional de bens de capital. Ainda que o II PND não o diga, esta concepção colocava no centro do palco da industrialização brasileira a grande empresa estatal"(LESSA, 1988, 1998:105).

Este dinamismo industrial sofreria uma inflexão em setembro de 1982, quando cessa a entrada de recursos externos ao país, após as decisões tomadas pelo Fundo Monetário Internacional em Toronto (OLIVEIRA, 1991:175).

Para completarmos o quadro que nos permitirá entender com mais precisão a evolução do sistema bancário nacional no período, faz-se necessário destacar quais os sistemas técnicos que permitiram a conexão dos fluxos "imateriais" do território (informações, mensagens, imagens, ondas de rádio). Com a construção das redes-suporte das telecomunicaçóes é que podemos dizer que passamos de um período técnico-científico para um período técnico-científico-informacional de nossa história.

\subsection{A expansão do meio técnico-científico-informacional: integração imaterial do território}

A partir da década de 1960, mas com grande ênfase nos anos 1970 e 1980, são desenvolvidos uma série de sistemas de engenharia no território, absolutamente necessários à modernização dos fluxos "imateriais" aqui presentes: estamos falando da renovação das nossas "bases materiais das telecomunicações" (SANTOS e SILVEIRA, 2001:73 e ss.). Segundo ainda Santos e Silveira (2001:73), "do telégrafo ao telefone e ao telex, do fax e do computador ao satélite, à fibra ótica e à Internet, o desenvolvimento das telecomunicações participou vigorosamente do jogo entre separação material das atividades e unificação organizacional dos comandos". 
A unificação do território por meio do desenvolvimento de sistemas técnicos voltados especificamente para os fluxos de informação no País é também um dado do período da integração e creditização do espaço nacional, e que merece ser destacado. O processo de institucionalização das preocupações do Governo Federal com o domínio desta "variável estratégica" é um bom exemplo de como os novos eventos ligados ao controle e circulação da informação passam a fazer parte dos conteúdos do território brasileiro.

Assim, a partir já do ano de 1962 (com a criação do Código Brasileiro de Telecomunicaçôes), são erigidos os primeiros organismos burocráticos com a tarefa de impulsionar esta renovação da base de telecomunicações do País; estes organismos podem ser considerados os atores que cuidarão da instalação de uma “nova geografia da circulação no espaço brasileiro"(DIAS, 1995:52):

a) Sistema Nacional de Telecomunicaçóes (que visava assegurar o funcionamento integrado de todas as iniciativas a partir dali);

b) Conselho Nacional de Telecomunicações (CONTEL), que cuidaria da definição dos padrões e das tarifas a serem praticadas pelo sistema; e criação do Departamento Nacional de Telecomunicações (DENTEL), que funcionaria como órgão executivo do CONTEL (1963);

c) constituição da Empresa Brasileira de Telecomunicações (EMBRATEL), em 1965, que exploraria industrialmente os sistemas de engenharia a serem instalados no espaço nacional;

d) implementação, em 1967, do Ministério das Comunicações. Fruto da própria complexificação das atividades desenvolvidas, "em 25 de fevereiro de 1967, através do Decreto-Lei n 200, foi criado o Ministério das Comunicações, ao qual, desde logo, foram vinculados o CONTEL, o DENTEL e a EMBRATEL" (ANATEL, 2006);

e) por último, mas não menos importante, é criada a Telecomunicações Brasileiras $S / A$ (TELEBRÁS), entidade incumbida de planejar e coordenar todo o esforço de renovação desses sistemas de engenharia no país. Assim como foi o caso da 
ELETROBRÁS para a geração/transmissão de energia, a TELEBRÁS foi criada para aumentar as sinergias organizacionais das infra-estruturas de telecomunicações ${ }^{66}$.

A evolução deste sistema contribuiu para tornar a base material do território mais moderna, sobrepondo às redes de transporte material novas infra-estruturas, capazes de integrar o espaço nacional através do deslocamento de imagens, sons, bits, informações etc. Antes da introdução destes novos sistemas técnicos no país, as informações circulavam comumente junto às redes-suporte mais restritas lou menos capilarizadas), como cabos submarinos, redes de telex, sistema de correio aéreo etc.

Do ponto de vista da evolução dos sistemas de engenharia que passam a compor esses novos conteúdos informacionais do território, faz-se necessário destacar ao menos três principais processos:

1) a evolução da rede telefônica: utilizada ao menos desde 1948, demora quase um quarto de século para dobrar sua extensão no território (DIAS, 1995:96); a partir de meados da década de 1970, seu crescimento é pronunciado, e passa a ser uma alternativa à transmissão de dados por parte das empresas e das autarquias governamentais demandantes;

2) até o final dos anos 1960, a base técnica do território permitia que as telecomunicações se dessem sobre três principais tecnologias: ondas curtas, cabos submarinos (com baixa capacidade de transmissão) e ondas hertzianas (conhecidas também como "ondas de rádio"); os fluxos de ondas hertzianas, por seu turno, concentravam-se principalmente em dois eixos do território: Rio de Janeiro-São Paulo-Campinas e Rio de Janeiro-Belo Horizonte-Brasília-Goiânia. Daí podermos dizer que a integração, até esta época, era uma integração restrita, que não permitia um alcance nacional por parte dos sistemas de ação das grandes empresas (e mesmo do

\footnotetext{
66 "Logo após sua criação, a TELEBRÁS iniciou o processo de aquisição e absorção das empresas que prestavam serviços telefônicos no Brasil, visando consolidá-las em empresas de âmbito estadual. Havia nessa época mais de novecentas operadoras independentes no Brasil e, no total, uma planta de cerca de dois milhões de terminais. Através do Decreto $\mathrm{n}^{\circ} 74.379$, de 1974, a TELEBRÁS foi designada "concessionária geral" para exploração dos serviços públicos de telecomunicações em todo o território nacional."(ANATEL, 2006).
} 
Governo Federal) no território brasileiro. Até se tornar uma rede "reconhecidamente nacional", em 1972, as conexões do território por ondas hertzianas seguiriam a seguinte evolução:

Quadro 2: Brasil: Conexões por Visibilidade e por Tropodifusão no Território (1972)

\begin{tabular}{|l|l|l|}
\hline \multicolumn{3}{|c|}{ LIGAÇÕES NACIONAIS } \\
\hline Período & \multicolumn{1}{|c|}{ Por “visibilidade" } & \multicolumn{1}{c|}{ Por "tropodifusão" } \\
\hline Antes de 1969 & $\begin{array}{l}\text { São Paulo-Curitiba } \\
\text { Belo Horizonte-Brasília } \\
\text { Rio de Janeiro-São Paulo }\end{array}$ & $\begin{array}{l}\text { Curitiba-Porto Alegre } \\
\text { B. Horizonte-Rio de Janeiro }\end{array}$ \\
\hline $1969-1970$ & $\begin{array}{l}\text { São Paulo-Curitiba } \\
\text { B. Horizonte-Salvador } \\
\text { Uberaba-Brasília } \\
\text { Campo Grande-Corumbá-Cuiabá } \\
\text { Belém-Manaus }\end{array}$ & $\begin{array}{l}\text { Curitiba-Florianópolis } \\
\text { São Paulo-Rib. Preto-Uberaba } \\
\text { Recife-Fortaleza } \\
\text { Rio de Janeiro-Vitória }\end{array}$ \\
\hline $1971-1972$ & $\begin{array}{l}\text { Belém-Braślia } \\
\text { Fortaleza-Teresina } \\
\text { Porto Velho-Rio Branco }\end{array}$ & $\begin{array}{l}\text { São Luís-Belém } \\
\text { Cuiabá-Porto Velho }\end{array}$ \\
\hline $1977-1978$ & $\begin{array}{l}\text { São Paulo-Belo Horizonte } \\
\text { Cuiabá-Goiânia }\end{array}$ & \\
\hline Belo Horizonte-Brasília & $\begin{array}{l}\text { Curitiba-Bauru } \\
\text { Rio de Janeiro-Vitória } \\
\text { Vitória-Salvador }\end{array}$ & \\
\hline $1981-1983$ & $\begin{array}{l}\text { Salvador-Fortaleza } \\
\text { Cuiabá-Porto Velho }\end{array}$ & \\
\hline
\end{tabular}

Fonte: DIAS, Leila (1995:94)

Apesar de ser considerada como uma rede "nacional" por parte da Embratel, as ligações por vias hertzianas na verdade atingem apenas as regiões próximas às cidades descritas no quadro acima. Segundo Leila Dias (1995), quando muito, cerca de metade dos municípios (55\%) brasileiros eram servidos por ligações telefônicas no período contemplado no quadro acima.

3) utilização de satélites: a partir de 1969 também, o Brasil começa a utilizar o satélite INTELSAT (International Telecommunication Satellite Organisation), para as ligações internacionais do país (a partir de uma estação terrestre instalada na cidade do Rio de Janeiro). Em 1985 é lançado o primeiro satélite brasileiro (o Brasilsat I), e no ano seguinte o Brasilsat II; as principais estações terrestres destes satélites foram instaladas principalmente na região Norte do país (dada a ausência de redes-suporte 
terrestres que permitissem as telecomunicações desta parcela do território com o resto do país].

Como já foi frisado, o sistema técnico composto pelos satélites em órbita, e seus respectivos retransmissores instalados em pontos estratégicos do território, conseguem conectar lugares inóspitos do espaço nacional, aumentando assim a quantidade de usos possíveis destas partes do território em questão (CASTILLO, 1999). Como nos lembra a geógrafa Leila Dias,

\begin{abstract}
“A reorganização do espaço nacional, condição indispensável à realização do modelo nacional de desenvolvimento, acompanhou as transformações do setor industrial. Em menos de vinte anos as redes de suporte de telecomunicações microondas e estações terrestres de satélites - cobriram o conjunto do território, permitindo a operacionalização das diferentes redes de serviço telefonia, transmissão de dados etc."(DIAS, 2005:31).
\end{abstract}

Esta integração mais sofisticada do território brasileiro (tanto do ponto de vista da circulação material, quanto informacional) vai ser utilizada pelo sistema bancário brasileiro, que passa a modernizar e difundir com mais vigor suas formas organizacionais e materiais pelo território. Pode-se dizer mesmo que a possibilidade de um comando mais centralizado das atividades econômicas (permitida pela utilização desta nova base informacional) é uma das responsáveis pela própria "concentração bancária" que ocorreria no país a partir do ano de 1964.

Ainda no que diz respeito à relação do sistema financeiro e bancário com esta nova base técnica, há também uma reestruturação das instituições financeiras, fruto em grande parte das alterações normativas propugnadas pela chamada "Reforma Bancária", que ocorreria a partir do ano de 1964. Tanto as técnicas da informação, quanto as normas são dois conteúdos do espaço geográfico que passam cada vez mais a influenciar as formas de organização das atividades produtivas no país. 


\section{CAPÍTULO 6. A Formação do Moderno Sistema Financeiro e a Reforma Bancária de 1964-1965}

\subsection{Novos sistemas técnicos bancários no país: a passagem do fazer mecânico para o fazer automático}

O acréscimo de novos objetos técnicos no território iria permitir às atividades industriais de geração de energia e de transportes um novo leque de possibilidades de organização. O território brasileiro se torna também mais atraente para as grandes multinacionais e, em vários ramos de atividade, corporações estrangeiras, grupos empresariais nacionais e Estado passam a atuar conjuntamente (EVANS, 1980).

No Brasil, essa nova base técnico-científica informacional permitiu a instalação das primeiras indústrias ligadas à produção de equipamentos para a automação bancária de nosso sistema financeiro. A partir do início dos anos 1970 passam a ser realizados pesados investimentos do Governo Federal para que fossem desenvolvidas empresas nacionais dinâmicas no ramo da automação bancária (FASSY, 1981; DIAS, 1995).

O fato é que o aumento das necessidades de circulação de dinheiro no território vai requerer também a renovação dos sistemas técnicos bancários, com a introdução de novos sistemas de objetos informacionais, como redes de computadores, de caixas eletrônicos, sistemas de transmissão de dados etc. Segundo Hindemburgo Pires, "o crescimento dos volumes de depósitos e de transações financeiras, a partir de meados dos anos 60, passou a requisitar a utilização da tecnologia dos CPD's (Centros de Processamento de Dados)" (PIRES, 1997:5), por exemplo. Era o sinal de um novo período que se abria no sistema bancário brasileiro, um sistema que gradualmente adquiria importância maior no País. 
Neste período, assevera Leila Dias, "o poder dos bancos cresce de maneira impressionante"(DIAS, 1995:106). Um dos elementos que aumentou a importância do sistema bancário no comando dos usos do território brasileiro foi justamente a evolução contínua da utilização de modernas técnicas bancárias. Com esta evolução tecnológica e organizacional, os atores financeiros tornam-se mais eficientes - aumentando o desempenho de sua rede de drenagem de recursos no território nacional - assim como é possibilitado o controle mais centralizado do sistema, por um número menor de atores.

No que diz respeito ao processo de evolução dos sistemas técnicos bancários para este período, podemos dividi-lo em quatro principais fases ${ }^{67}$ :

$1^{\text {a }}$. Fase (1965-1970): gênese da automação bancária

Do ponto de vista do funcionamento das agências, as formas tradicionais de contabilidade (manuais, escritas) são gradualmente substituídas pela utilização de cartões e máquinas de contabilizar, que permitem uma maior agilidade no "fechamento das contas" diário dos bancos. Essas novas formas de organização do trabalho bancário possibilitavam ainda uma redução dos custos do processamento das informações. O grande número do aumento dos depósitos e das transações financeiras exigia objetos técnicos mais sofisticados, que dessem conta dessa velocidade e quantidade inaudita de informações e recursos que o sistema financeiro passaria a receber ${ }^{68}$.

Neste subperíodo, pode-se dizer que havia duas fases no processamento de dados por parte dos bancos: numa primeira fase, os saldos das contas eram relacionados em listagens nas agências, e modificados (se necessário) durante o expediente, sem preocupação contábil. Após esse processo, os Centros de Processamento de

${ }^{67}$ Esta subperiodização foi estabelecida principalmente através da análise dos trabalhos de André Accorsi (1990) e Hindemburgo Pires (1997).

68 "São os enormes volumes de lançamentos na conta depósito, surgidos após 1964 que exigiriam a criação dos centros de processamento de dados (CPD's). O processamento ocorria durante a noite para que no dia seguinte as agências pudessem abrir com o saldo do cliente atualizado"(ACCORSI, 1990:34). 
Dados (CPD's) eram alimentados nos períodos noturnos, "tentando centralizar as informações de todas as agências"(ACCORSI: 1990:34).

No que diz respeito aos fluxos de informaçóes entre as unidades de cada rede bancária, podemos dizer junto de Hindemburgo Pires (1997:3) que, "as informações e decisões eram centralizadas em CPD's e grandes mainframes, instalados de modo preferencial nos centros de gestão territorial" que, nesta época, eram basicamente São Paulo, Rio de Janeiro, Brasília e Belo Horizonte. Vale destacar ainda que as instituições financeiras utilizavam neste período a rede nacional de Telex para garantir a transmissão de informações entre suas agências.

$2^{\text {a }}$. Fase (1970-1976): A introdução dos computadores nos sistemas de ação bancários

Neste subperíodo os próprios agentes do sistema financeiro (principalmente os grandes bancos nacionais) são chamados a investir no desenvolvimento de sistemas técnicos que permitissem um processamento cada vez mais informatizado dos dados de cada instituição. Como nos lembra Leila Dias (1995:114 e seguintes), o Banco Brasileiro de Descontos (Bradesco) é uma das instituições financeiras nacionais que investe fortemente neste processo de automação.

O principal objeto técnico que vai permitir uma multiplicação enorme das possibilidades do "fazer bancário" é o computador, que cada vez mais se torna parte essencial das instituições financeiras. Como lembra André Accorsi lop. cit.35), "o computador passou a ser o único a processar as informações, integrando contabilmente as agências, abandonando-se o sistema de controle de cartelas nas agências" ${ }^{69}$.

\footnotetext{
${ }^{69}$ A grande vantagem da introdução do computador, no que diz respeito à organização bancária, é o fato dela permitir em definitivo a substituição dos métodos contábeis mais antigos, passando a prevalecer o que Accorsi denominou de "órgãos para-contábeis", isto é, parcelas das atividades bancárias muito mais relacionadas com o controle da informação, que se produzia em níveis cada vez mais vultosos. A modernização concomitante dos sistemas de objetos utilizados pelos bancos permitiu ainda uma eficiência jamais vista na manipulação e transmissão geográfica destas informações, evitando "a distorção criada pela distância entre a origem do fato e seu registro efetivo na data correta"(ACCORSI, op. cit:: 35).
} 
3a. Fase (1976-1980): A descentralização do processamento das informações bancárias

A evolução dos sistemas de telecomunicações possibilitou também uma nova organização das operações internas aos bancos. Neste terceiro subperíodo da automação bancária, as ligações dos Centros de Processamento de Dados (CPD's) dos bancos com sua rede de agências já "era feita por linha privada da telefonia"(ACCORSI, 1990:35).

As infra-estruturas técnicas instaladas pela EMBRATEL no território trazem novas possibilidades organizacionais para os agentes financeiros. Fala-se numa "descentralização do processamento das informações" pois são instalados minicomputadores em várias agências no interior dos principais estados, de acordo com a quantidade de informações geradas por cada região (PIRES, 1997:3). Podemos destacar ainda que essa descentralização tinha como principal característica a "digitação remota, a transmissão do dado digitado, o processamento centralizado, a transmissão do dado processado e impressão remota dos dados necessários à abertura da agência"(ACCORSI, 1990:35).

Essa evolução da utilização da nova "base material das telecomunicações" (SANTOS e SILVEIRA, 2001:73) permitiu ainda que os bancos se regionalizassem de maneira distinta dos padrões anteriores. Se numa determinada área de atuação de um banco houvesse a geração de um número grande de informações processáveis, criava-se um "centro de processamento regional", para tornar mais eficiente a ação da instituição financeira em questão. Este processo passa a se dar também na escala das próprias agências ${ }^{70}$.

\footnotetext{
70 “Basicamente havia duas opções na descentralização: a nível de região e a nível de agência. No primeiro caso criaram-se sub-centros de processamento que passaram a remeter dados consolidados para o CPD, que tinha a função maior, gerencial e de consolidação da contabilidade. No segundo caso tínhamos agências, de grande movimento, com equipamento de pequeno porte transmitindo informações consolidadas ao CPD" (ACCORSI, op. cit.35).
} 
4a. Fase (início em 1980): Processamento instantâneo das informações bancárias

Este quarto subperíodo expressaria, por fim, uma maior unicidade do sistema bancário brasileiro, além de representar um aumento expressivo das possibilidades de transporte de informações. A instantaneidade, por seu turno, aumenta ainda a velocidade da circulação do dinheiro no território, imprimindo nos lugares conectados às redes bancárias novos ritmos de funcionamento.

A partir do ano de 1980 os "processamentos em lote dos dados" (chamado "processo batch") são substituídos pelo processamento on-line das informações. Em todas as agências bancárias são instalados terminais de computadores para a entrada de dados dos clientes que, por sua vez, alimentariam ininterruptamente o CPD das matrizes. Os terminais, portanto, passam a oferecer aos clientes também instantaneamente informações atualizadas sobre suas contas, aumentando a possibilidade de consulta e manipulação dos valores trabalhados com os bancos.

Vale destacar ainda que o processamento "on-line" permitiria a eliminação da chamada "flutuação dos valores", isto é, a alteração da riqueza em poder dos bancos pelo processo inflacionário da época. A "flutuação" é eliminada naturalmente com a introdução deste processamento, "uma vez que o lançamento contábil completo se dava no momento em que o fato ocorre, com o aproveitamento direto da digitação realizada na agência" (ACCORSI, 1990:35).

As principais novidades organizacionais e tecnológicas deste subperíodo seriam as seguintes:

a) é aumentado sensivelmente o porte dos sistemas técnicos em termos de capacidade de processamento das informações bancárias. Essa maior dependência da organização do sistema bancário em relação às novas técnicas informacionais vai criar também uma demanda maior por serviços técnicos, executáveis somente por pessoal qualificado para operar e prestar manutenção aos sistemas instalados; 
b) passa a ser possível um controle mais centralizado das organizações bancárias, por parte de suas estruturas dirigentes. A centralização das informações conseguida com a evolução dos sistemas técnicos bancários permite uma visão global sobre os processos de cobrança, de controle das contas-corrente, dos depósitos, de controle de custos, antes impossíveis. Ao passo que ocorre uma descentralização das informações e das funções de cada agência, concretiza-se a possibilidade de comando/tomada de decisões centralizadas a partir delas;

c) assistimos a uma "aceleração dos ritmos econômicos" (DIAS, 1995:106) do território, sob hegemonia da temporalidade do sistema financeiro. As instituições bancárias ganham esta primazia pois passam a trabalhar com uma nova concepção de tempo, instantânea e interdependente. Nas palavras de André Accorsi (op. cit::36), as ações dos bancos passam a ser "temporalmente interdependentes", já que esta instantaneidade coloca os diferentes agentes de cada instituição em contato mais direto uns com os outros.

Estas são, portanto, as características basilares do processo de transformação dos sistemas técnicos e das formas de organização do trabalho nos bancos, permitido pela chamada "automação bancária". Apesar de todas as instituições financeiras se engajarem neste processo, as diferenças se darão na capacidade de cada ator em acompanhar a internalização destes novos dados do período técnico-científico informacional.

Vale lembrar ainda que, a par da política governamental voltada para a informatização da atividade bancária, o Estado brasileiro trabalhava também claramente para a diminuição do número de bancos operando no território, como nos lembram Ary Bouzan (1972) e Natermes Teixeira (2000). Esta "concentração bancária", por sua vez, está diretamente relacionada com os novos conteúdos normativos do território instalados pelo que se convencionou chamar de "Reforma Bancária", ocorrida nos anos de 1964 e 1965. 


\subsection{Os novos conteúdos normativos do território: a reforma bancária de $1964 / 65$}

As normas jurídicas que geraram a "Reforma Bancária" no Brasil foram basicamente a Lei no. 4.595 de 31.12.1964 - a chamada "Lei da Reforma Bancária"(OLIVEIRA, 1979:59) - e a Lei no. 4.728 de 14.07.1965 - conhecida também como a "Lei do Mercado de Capitais". Ambas estão na base da alteração dos conteúdos normativos do território, e deram corpo legal para uma necessidade de mudança na divisão financeira do trabalho que vinha se processando, concomitantemente à instalação do meio técnico-científico informacional no território brasileiro.

Conforme vimos no capítulo 3, até o ano de 1964 (isto é, antes da promulgação das Leis que geraram a Reforma), o sistema financeiro tinha sua estrutura básica assim desenhada: a) o próprio Tesouro Nacional era responsável pela emissão de papel-moeda; b) a Superintendência da Moeda e do Crédito (SUMOC) era o principal órgão normativo, responsável pela regulamentação última das políticas monetária e creditícia; c) o Banco do Brasil (que controlava cerca de $20 \%$ dos totais dos depósitos da nação da época) era tanto o "garantidor em última instância" do sistema financeiro nacional, como era o principal banco comercial e o principal "banco de investimento" do país (SILVA, 1981:9).

Adroaldo Silva (1981) vislumbrava alguns "problemas estruturais" que este sistema financeiro possuía:

1) não havia um mercado de capitais desenvolvido no país; assim, era dificultada a colocação de títulos (públicos e privados) e ações à venda, forma comum de financiamento do Estado e das empresas nos países de capitalismo mais desenvolvido ${ }^{71}$;

\footnotetext{
71 Segundo ainda Bulhões (et alli, 1976), até o final dos anos 1950, "o mercado acionário praticamente inexistia - dentre outros motivos pela tradição da empresa familiar fechada - não havendo a possibilidade de lançamento de obrigações primárias sob a forma de ações, ficando as empresas sujeitas ao autofinanciamento e principalmente ao débito (ao invés da capitalização) através de notas promissórias e dívidas com fornecedores"(BULHÕES, 1976:130).
} 
2) as empresas estatais (que como vimos, tiveram papel central na construção do meio técnico-científico no país), eram financiadas em grande parte por recursos do orçamento da União, e através de receitas próprias. Já que boa parte das estatais gerava déficits constantes, estas obrigavam muitas vezes o Tesouro a imprimir papel-moeda e esta emissão, por sua vez, gerava inflação;

3) não se desenvolveram instituições financeiras que pudessem emprestar capitais a longo prazo no território, concomitantemente à expansão da atividade industrial no país; daí serem aumentadas as dificuldades para o ajuste entre o sistema financeiro e o sistema produtivo nacional (SILVA, 1981:10).

A identificação destes problemas acima mencionados por parte do Executivo Federal levou à implementação de uma série de novas normas, políticas públicas e criação de autarquias, consubstanciada no chamado Plano de Ação Econômica do Governo (PAEG). Segundo Fabio Giambiaggi e Ana Claudia Além (1999:76), o "PAEG tinha como principal objetivo o controle do processo inflacionário, combinado com a retomada do desenvolvimento econômico", e que "introduziu uma série de reformas estruturais visando a modernização e adequação dos mecanismos financeiros à situação econômica então vigente"[1999:76).

Em sua relação com o sistema financeiro, podemos dividir em três as principais mudanças introduzidas pelo Plano de Ação Econômica do Governo (PAEG): seria executada uma "reforma fiscal", uma reforma na "política habitacional", e finalmente uma reforma da remuneração dos títulos públicos do governo, com a institucionalização da "correção monetária". Vejamos mais de perto cada uma destas mudanças.

Através da "reforma fiscal", o executivo federal pretendia aumentar, em primeiro lugar, a concessão de incentivos fiscais para que as empresas privadas investissem nos "setores estratégicos", principalmente aquelas atividades que viessem a incrementar o 
desenvolvimento e a autonomia econômica do país. Com essa "reforma", seriam também centralizados sob comando do Governo Federal a arrecadação dos impostos no território, já que o controle unificado era necessário para o financiamento dos enormes sistemas de engenharia industriais, energéticos, de transporte, telecomunicações etc. que estavam já sendo construídos, ou que se constituíam em demandas prementes para a integração do território. Por fim, através da "reforma fiscal" seriam ainda isentas de taxação a maior parte dos circuitos geográficos de exportação, tanto para incrementar a inserção do país no comércio mundial, assim como para ajudar no equilíbrio da moeda (mercado de câmbio).

Além da "reforma fiscal", era parte constitutiva do Plano de Ação Econômica do Governo uma reforma na área da "política habitacional". Assim é que, através da Lei 4.380 de 1964, cria-se o Sistema Financeiro da Habitação, que por sua vez se dividiria em duas principais instituições: a) o Banco Nacional da Habitação (BNH), responsável pela concessão de empréstimos para a construção/compra de casas populares; e b) constituição de "sociedades de crédito imobiliário", por parte da iniciativa privada. Já que o território se urbanizava em ritmo mais acelerado, o sistema financeiro é adaptado para procurar suprir estas novas necessidades habitacionais 72 .

O último, mas não menos importante evento gerado pelo PAEG à época foi a institucionalização da correção monetária no país. A correção monetária, que inicialmente serviu para remunerar apenas os títulos públicos colocados no mercado de capitais em formação ${ }^{73}$, permitiu gradualmente que fossem também remunerados todos os depósitos no sistema bancário com taxas de juros positivas

72 Para fomentar o Banco Nacional da Habitação e as demais instituições vinculadas ao financiamento da habitação (caixas econômicas, sociedades de crédito imobiliário etc.) foi criado o instrumento "parafiscal" conhecido como Fundo de Garantia por Tempo de Serviço (FGTS). A partir de sua criação, o BNH vai tomando uma dimensão bastante importante no sistema financeiro nacional, dada a quantidade de recursos que passa gradativamente a controlar: em 1968 , seus ativos já chegavam a $1 \%$ do Produto Interno Bruto do país; em 1978, essa porcentagem sobe para 6,4\%. (GOLDSMITH, 1986:399).

73 Segundo Natermes Teixeira (2000:35), “A utilização da correção monetária estava inicialmente ligada a problemas quase que exclusivos do setor público", e tinha nas Obrigações Reajustáveis do Tesouro Nacional [ORTN's] seu principal instrumento de atualização da remuneração dos títulos públicos. Após sua disseminação como forma de correção dos valores dos papéis do Governo Federal, "a correção monetária foi estendida ao setor imobiliário (...) e, num segundo momento, generalizada no âmbito do mercado financeirocreditício interno. Em resumo, o instituto da correção monetária, a partir de seu uso generalizado, viria a ser o pretenso instrumento capaz de eliminar um sem-número de distorções no campo das finanças públicas e da intermediação financeira institucional". 
(o que não ocorreu em boa parte de nossa história financeira, como vimos). Segundo Fabio Giambiaggi e Ana Claudia Além,

“a introdução da correção monetária viabilizou não apenas a criação de um mercado voluntário para os títulos públicos, mas também colaborou para: a) a obtenção de recursos adicionais para a cobertura do déficit da união; b) a redução da perda de receita associada ao atraso no pagamento de débitos fiscais e c) o estímulo à poupança individual"(GIAMBIAGGl e ALÉM, 1999:78).

Estas importantes mudanças trazidas pela aplicação da correção monetária é que permitiram ao economista Ignácio Rangel asseverar que esta implantação foi, na verdade, "escola maternal do capitalismo financeiro moderno do Brasil" (RANGEL, 1980:114).

Com a correção monetária é aumentado sensivelmente o interesse dos atores econômicos por operações financeiras, permitindo que o sistema bancário começasse a drenar do território uma quantidade de recursos suficiente para o financiamento de atividades nos prazos médio e longo também. Com relação ainda às contas do Governo Federal, a institucionalização da correção monetária teve papel central, como lembram Giambiaggi e Além (1999:78): "na prática, pôde-se contornar a lei da usura (...), permitindo então taxas de juros reais positivas nas transações financeiras, condição fundamental para viabilizar a colocação de títulos públicos" no mercado de capitais em formação.

Segundo Octávio Gouveia de Bulhões (1976:139), essa nova modalidade de remuneração dos ativos financeiros teve "efeito espetacular", aumentando sensivelmente a "relação ativos financeiros/PIB, declinante desde 1947". Ary Bouzan (1972) destaca ainda que a correção monetária permitiu aos bancos fazerem crescer os depósitos a prazo de seus clientes, fato extremamente importante para o financiamento de empresas e de sistemas de engenharia, cujos horizontes de maturação dos investimentos exigiam escalas temporais mais dilatadas. No que diz respeito ao sistema bancário, portanto, a correção monetária 
"de um lado Ihes permite captar depósitos de poupança; de outro lhes permite fazer aplicações a maiores prazos" (BOUZAN, 1972:153).

Estas são, portanto, as principais alterações nas normas e nas técnicas financeiras, que permitem um incremento do poder das instituições bancárias no conjunto das atividades econômicas desenvolvidas no território brasileiro. Concomitantemente a estes novos conteúdos financeiros e normativos, uma nova divisão do trabalho é instalada no sistema financeiro, com a criação de uma série de novos atores, que conferirão uma racionalidade ainda maior ao uso financeiro do território brasileiro.

\subsection{O Sistema Financeiro Nacional no período técnico-científico- informacional}

Com as reformas nos conteúdos normativos e financeiros implementados a partir do ano de 1964, e dada a nova realidade material do território (mais integrada em termos de transportes e de comunicações), é que podemos falar verdadeiramente na formação do Sistema Financeiro Nacional (SFN) ${ }^{74}$. Tanto pelos novos atores que são criados a partir da reforma e pela sua especialização, quanto pelo aumento da racionalidade que é introduzida no sistema montado, podemos dizer que a organização das atividades financeiras adquire uma maior funcionalidade e um alcance nacional.

No que diz respeito à nova divisão financeira do trabalho, é possível afirmar que as funções que cada instituição assumiria seriam definidas a partir do "princípio da compartimentalização" (BULHÕES et alli, 1976:141). Esse princípio indicava que "as unidades se especializavam em determinadas operações", de acordo com as necessidades dos agentes públicos e privados, instalados no território. Quais seriam, então, as novas instituições? Que tipos de novas técnicas financeiras passam a ser praticadas em território brasileiro? Quais os atores públicos criados,

${ }^{74}$ O Sistema Financeiro Nacional pode ser definido como a estrutura "responsável pela coordenação política e financeira e pelos serviços bancários, monetários e creditícios do país. As instituições financeiras que integram o SFN dividem-se em dois grandes grupos: o primeiro, o dos intermediários financeiros, e o segundo, o das instituições auxiliares." (BIDERMAN, 2006:361). 
e quais os atores privados que passam a compor o sistema agora "compartimentalizado"?

No que tange à atividade bancária privada, vale destacar em primeiro lugar que neste período "procurou-se reter ao máximo o controle interno" do sistema financeiro, "já que era considerado um setor nacional estratégico", nas palavras de Mônica Baer (1986:13). A internacionalização do sistema financeiro que ocorreu na época, ainda segundo a autora, se deu muito mais pelas facilidades proporcionadas para a tomada de empréstimos no exterior por parte dos bancos nacionais, do que pela compra de instituições nacionais por capitais estrangeiros (BAER, 1986:17).

A nova divisão financeira do trabalho poderia ser assim resumida:

Quadro 3: Estrutura do Sistema Financeiro Brasileiro a partir da Reforma de 1964/65
1) Autoridades Monetárias
a) Conselho Monetário Nacional (CMN)
b) Banco Central do Brasil (BC)
c) Comissão de Valores Mobiliários (CVM)

\section{2) Demais instituições}

\begin{tabular}{|c|c|c|}
\hline \multicolumn{2}{|l|}{ Tipo de instituição } & \multirow{2}{*}{$\begin{array}{l}\text { Função na divisão bancária do } \\
\text { trabalho }\end{array}$} \\
\hline Setor privado & Setor público & \\
\hline Bancos Comerciais & $\begin{array}{l}\text { Bancos Comerciais e Banco } \\
\text { do Brasil }\end{array}$ & $\begin{array}{l}\text { Fornecer crédito de curto prazo } \\
\text { e financiamentos para setores } \\
\text { prioritários }\end{array}$ \\
\hline Bancos de Investimento & $\begin{array}{l}\text { Bancos de Desenvolvimento, } \\
\text { Nacionais e Regionais }\end{array}$ & $\begin{array}{l}\text { Fornecer crédito de médio e } \\
\text { longo prazos, e financiar } \\
\text { programas de desenvolvimento }\end{array}$ \\
\hline $\begin{array}{l}\text { Companhias } \\
\text { Arrendamento } \\
\text { (Leasing) }\end{array}$ & & $\begin{array}{l}\text { Fornecer créditos de longo } \\
\text { prazo }\end{array}$ \\
\hline $\begin{array}{l}\text { Sociedades de Crédito } \\
\text { ("financeiras") }\end{array}$ & & $\begin{array}{l}\text { Fornecer crédito ao consumo de } \\
\text { bens duráveis }\end{array}$ \\
\hline $\begin{array}{l}\text { Sociedades de Crédito } \\
\text { Imobiliário }\end{array}$ & $\begin{array}{l}\text { BNH e Caixas Econômicas } \\
\text { (federal e estaduais) }\end{array}$ & 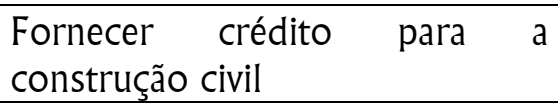 \\
\hline $\begin{array}{l}\text { Instituições Vinculadas } \\
\text { à Operação na Bolsa de } \\
\text { Valores }\end{array}$ & & $\begin{array}{l}\text { Agilizar a operação na Bolsa de } \\
\text { Valores }\end{array}$ \\
\hline
\end{tabular}

Fonte: Elaboração própria a partir de Mônica Baer (1968:15) 
No caso da nova Autoridade Monetária constituída, a primeira instituição que merece ser destacada é o Conselho Monetário Nacional (CMN). Da criação do Conselho decorre automaticamente a extinção da Superintendência da Moeda e do Crédito (SUMOC), e ele passa ser o principal órgão normativo do Sistema Financeiro. O CMN viria, assim, a desempenhar as seguintes funções na divisão financeira do trabalho (OLIVEIRA, 1979): a) adaptar o volume dos meios de pagamentos às necessidades da economia; b) regular o valor interno da moeda; c) regular o valor externo da moeda, e o equilíbrio no balanço de pagamentos do país; d) orientar a aplicação dos recursos das instituições financeiras públicas ou privadas; e) propiciar o aperfeiçoamento das instituições e dos instrumentos financeiros; f) zelar pela liquidez e solvência das instituições financeiras; g) coordenar as políticas monetária, creditícia, orçamentária, fiscal e da dívida pública, interna e externa; e finalmente $\mathrm{h}$ ) autorizar as emissões de papel-moeda.

A própria sofisticação das atribuições do Conselho indica que tanto as instituições, quanto as técnicas financeiras à disposição dos atores econômicos, são bastante mais complexas do que em períodos anteriores de nossa história financeira.

A segunda instituição mais importante criada também pela Lei 4.595 de 31/12/1964 é o Banco Central do Brasil (BC). O Banco Central seria, em termos mais gerais, o órgão de execução das políticas traçadas pelo Conselho Monetário Nacional. Caberia a este Banco, portanto: a) emitir papel-moeda e moeda metálica; b) executar os serviços do meio circulante; c) receber os recolhimentos compulsórios e os depósitos voluntários das instituições financeiras; d) realizar operações de redesconto e empréstimo a instituições financeiras bancárias; e) exercer o controle de crédito do sistema bancário; f) efetuar o controle dos capitais estrangeiros que adentrassem o território; g) ser depositário das reservas oficiais de ouro e moeda estrangeira; h) exercer a fiscalização das instituições financeiras e aplicar as penalidades previstas em lei; i) conceder autorização às instituições financeiras, a fim de que pudessem funcionar no país, estabelecer filiais no exterior, ou serem transformadas/fundidas/incorporadas; j) realizar, como 
instrumento de política monetária, operações de compra e venda de títulos públicos federais (OLIVEIRA, 1979).

A terceira e última alteração com maior relevância para a modernização do Sistema Financeiro Nacional foi a criação de um mercado de capitais sistematizado no país. Através da Lei no. 4.728 de julho de 1965 la chamada "Lei do Mercado de Capitais", conforme citado), são gestadas as condições para facilitar que as empresas (e o Governo) emitissem títulos e ações, que fossem negociados para o financiamento de suas atividades ${ }^{75}$.

A criação do Mercado de Capitais tinha três objetivos básicos: a) estabelecimento de "padrões de conduta para os participantes do Mercado"; b) criação de novas instituições financeiras, e "fortalecer as já existentes"; e c) concessão de incentivos às companhias para que abrissem seus capitais, isto é, lançassem ações na bolsa de valores (CASTRO, 1979:47) ${ }^{76}$.

Foi possibilitada, com a institucionalização dessas novas formas de organização das finanças, a criação de um mercado de títulos e de ações no Brasil, que estão na base do processo de "titularização" ou "desmaterialização" da riqueza do país. Logo no início da década de 1970, "o sistema financeiro passou a experimentar, dentro do segmento relativo ao mercado de ações, grande movimentação", lembranos Octávio Gouveia de Bulhões (1976:142). Dentre os novos produtos

\footnotetext{
75 Sem um mercado de capitais dinâmico, as empresas possuem duas formas principais de financiamento de suas atividades: a) os empréstimos junto ao sistema bancário; e b) o autofinanciamento. O Estado (principalmente no nível Federal), por sua vez, poderia financiar seus investimentos e despesas correntes através dos empréstimos, mas ainda com os recursos fiscais arrecadados (cobrança de impostos) e através da prerrogativa de emitir papel-moeda.

${ }^{76}$ Ainda no âmbito do Mercado de Capitais, agora regulamentado por legislação federal específica, cabe lembrar a importância de três outras instituições essenciais para seu funcionamento: as "financeiras", os "bancos de investimento" e a "comissão de valores mobiliários". As Sociedades de Crédito, Financiamento e Investimento (ou simplesmente "financeiras") seriam instituições especializadas na concessão de créditos de médio e longo prazos para o sistema produtivo nacional. Já os Bancos de Investimento são implementados pela Lei no. 4.728 de 1965, e se incumbiriam da realização de operações "em maior escala do que as realizadas pelas financeiras e com prazo mais longo do que o suprido pelos bancos comerciais"(OLIVEIRA, 1979:73/74). Por último, mas não menos importante, é criada a partir da Lei no. 6.385 de 1976 a Comissão de Valores Mobiliários (CVM). Esta Comissão deveria zelar para que os participantes do Mercado de Capitais seguissem critérios e técnicas financeiras que conferissem maior estabilidade ao sistema como um todo. Todos os títulos conceituados como "valores mobiliários" estariam sob o controle da Comissão.
} 
financeiros que passam a ser utilizados com mais vigor no sistema financeiro nacional, podemos destacar:

a) títulos públicos: são exemplos de títulos públicos surgidos neste período as Obrigações Reajustáveis do Tesouro Nacional (ORTN's) e as Letras do Tesouro Nacional (LTN's); vários Estados da federação passam também a emitir "títulos de Dívida Pública Estadual";

b) títulos privados: letras de câmbio, certificados de depósito bancário $\left(C D B^{\prime} s\right)$, recibo de depósito a prazo fixo, letras imobiliárias, ações, debêntures, cotas de fundos de investimento e cotas de fundos fiscais de investimento (ELIAS e SIMONI, 1979:91).

Podemos dizer que, em função destas mudanças descritas, é melhor sistematizada a divisão financeira do trabalho no território brasileiro, assim como novas operações financeiras são tornadas possíveis. Isto é, através do Sistema Financeiro não somente se criaram "novos intermediários financeiros", mas também foram criados "novos instrumentos de crédito" (PASSOS, 1973:66), que podem ser considerados como novas técnicas de intermediação financeira, que aumentam a importância do fenômeno das finanças no desenvolvimento do país.

\subsection{Os títulos públicos e o aumento da participação do Estado na renovação da base material da nação}

No período que se segue a estas alterações normativas e organizacionais do sistema financeiro brasileiro, ocorre também um aumento da participação das instituições financeiras oficiais (bancos federais, estaduais, caixas econômicas etc.) no financiamento da modernização dos sistemas de engenharia do território brasileiro. Este incremento da atuação de bancos oficiais é bastante tributário da 
possibilidade da utilização das novas técnicas financeiras, principalmente a da emissão de títulos públicos ${ }^{77}$.

Este processo é notado por Yttrio Costa Neto (2004:108), que utiliza o critério da "concessão de empréstimos" realizado pelo sistema financeiro para entender melhor o aumento da participação do Estado na economia nacional. A participação dos Bancos Oficiais nos totais de empréstimos passa de 62,5\% em 1968, para 63,3\% em 1970, para chegar a 66,05\% no ano de 1975 .

Wilson Suzigan (1976:107 e ss.) também nota que tanto nos "haveres" (quantidades de depósitos sob poder dos bancos oficiais) quanto na "concessão de empréstimos" (isto é, na "alocação" dos recursos disponíveis no sistema financeiro), a participação das instituições públicas dificilmente se situava em níveis menores que a metade dos totais circulantes.

A tabela 11, que mostra as porcentagens dos totais de empréstimos realizados no período em tela, nos permite uma melhor aproximação deste processo de financiamento das atividades econômicas por parte das instituições financeiras públicas e privadas:

\footnotetext{
77 Um título financeiro, em seu aspecto mais geral, pode ser entendido como um "documento que representa e identifica a propriedade de um determinado bem ou valor. Um título é emitido por instituições públicas ou privadas a fim de levantar recursos. O termo título é genericamente aplicado aos valores mobiliários"(BIDERMAN, 2006:3852). Os títulos públicos, ou "títulos da dívida pública, por seu turno, podem ser emitidos tanto pelas esferas federal, estadual ou municipal do Estado. Um título da dívida pública pode ser definido como um "título de crédito emitido e garantido pela União, ou por um estado ou município para arrecadar recursos com o objetivo de antecipar receitas ou suprir déficit orçamentário. A União, os estados e os municípios podem negociar títulos com investidores para levantar recursos. Esses títulos financeiros possuem diferentes taxas de juros, métodos de atualização monetária e prazos de vencimento diversificado. Podem ser na forma de apólice, bônus ou obrigação do Tesouro Nacional"(BIDERMAN, 2006:383).
} 
Tabela 11: Brasil: Empréstimos ao Setor Privado Realizado pelos Agentes do Sistema Financeiro (em \% dos totais) (1968-1975)

\begin{tabular}{|c|c|c|c|c|c|}
\hline Tipo de Instituição & 1968 & 1970 & 1973 & 1974 & 1975 \\
\hline Instituições Oficiais & 48,9 & 52,1 & 44,7 & 51,1 & 54,7 \\
\hline Federais & 37,4 & 39,5 & 32,2 & 37,5 & 40,5 \\
\hline Banco do Brasil & 22,7 & 22,0 & 19,0 & 21,6 & 22,9 \\
\hline BNB e BASA & 3,9 & 3,0 & 2,1 & 2,1 & 2,0 \\
\hline $\begin{array}{l}\text { Banco Nacional da Habitação } \\
\text { (BNH) }\end{array}$ & 3,3 & 5,6 & 3,1 & 2,5 & 2,0 \\
\hline Caixa Econômica Federal (CEF] & 3,8 & 4,7 & 4,9 & 5,6 & 7,2 \\
\hline $\begin{array}{l}\text { Banco Nacional. do Desenv. } \\
\text { Econômico (BNDE) }\end{array}$ & 3,4 & 4,0 & 2,0 & 4,2 & 5,4 \\
\hline Outros & 0,3 & 0,2 & 0,1 & 0,2 & 0,2 \\
\hline Estaduais & 11,5 & 12,6 & 12,5 & 13,6 & 14,2 \\
\hline Bancos Estaduais & 9,2 & 8,7 & 7,7 & 7,9 & 8,0 \\
\hline Financeiras & 0,1 & 0,2 & 0,5 & 0,6 & 0,6 \\
\hline Bancos de Investimento & - & 0,2 & 0,1 & 0,2 & 0,5 \\
\hline $\begin{array}{l}\text { Sociedades de } \\
\text { Imobiliário }\end{array}$ & - & 0,6 & 0,4 & 0,5 & 0,4 \\
\hline Caixas Econômicas Estaduais & 1,3 & 1,9 & 2,1 & 2,3 & 2,3 \\
\hline $\begin{array}{ll}\text { Bancos } \quad \text { Estaduais } & \text { de } \\
\text { Desenvolvimento } & \end{array}$ & 0,9 & 1,0 & 1,7 & 2,1 & 2,4 \\
\hline Instituições Privadas & 51,1 & 47,9 & 55,3 & 48,9 & 45,3 \\
\hline Bancos Comerciais & 30,6 & 24,6 & 21,3 & 19,2 & 18,2 \\
\hline Financeiras & 12,4 & 11,7 & 14,6 & 12,0 & 10,1 \\
\hline Bancos de Investimento & 5,4 & 8,2 & 12,6 & 10,6 & 10,5 \\
\hline $\begin{array}{lll}\text { Sociedades de } & \text { Crédito } \\
\text { Imobiliário } & & \\
\end{array}$ & 2,6 & 2,9 & 5,7 & 5,8 & 5,1 \\
\hline $\begin{array}{l}\text { Associações de Poupança e } \\
\text { Empréstimo }\end{array}$ & 0,1 & 0,5 & 1,1 & 1,3 & 1,4 \\
\hline
\end{tabular}

Fonte: Banco Central do Brasil; adaptado de SUZIGAN (1976:111]

Além do aumento sensível do peso dos sistemas de ação públicos neste contexto, ao menos dois dados nos chamam a atenção na tabela 11: em primeiro lugar, há um crescimento importante dos totais manejados pela Caixa Econômica Federal e pelo BNDE; ao final do período em questão teriam quase dobrado sua participação nos empréstimos. Em segundo lugar, ocorre uma diminuição relativa da importância dos bancos comerciais privados nos totais emprestados (de 30,6\% passam para $18,2 \%)$, com o concomitante aumento da participação dos chamados Bancos de Investimento (que de apenas 5,4\% dos totais emprestados passam para $10,5 \%$ dos mesmos no período). 
O quadro reflete, em grande medida, a própria estratégia eleita pelo Governo Federal da época, de aumentar a concessão de créditos através da rede de instituições públicas, já que estas teriam tanto uma topologia melhor distribuída pelo território, assim como poderiam emprestar em prazos mais longos. Assim, as principais ações de financiamento são colocadas sob responsabilidade dos bancos oficiais, fossem eles estaduais ou federais (notadamente a Caixa Econômica Federal, o Banco Nacional da Habitação, e o BNDE). Com relação à participação dos bancos comerciais privados nesta nova divisão financeira do trabalho, estes ficariam basicamente encarregados das operações de curto prazo, principalmente para o fornecimento de capital de giro para empresas.

Além do aumento na participação das instituições públicas no comando dos fluxos financeiros do território, houve também uma mudança na qualidade dos ativos financeiros que permitem o desenvolvimento econômico nacional. No que diz respeito ainda aos "haveres financeiros", Natermes Teixeira (2000:40) nos explica que de um sistema baseado em grande parte em "ativos monetários" (que são compostos basicamente de "depósitos à vista" e de "papel-moeda em poder do público"), passamos a um sistema mais dependente de "ativos não-monetários", como por exemplo: "depósitos de poupança", "depósitos a prazo", "letras de câmbio", e principalmente os "títulos da dívida pública". Estes últimos, em função mesmo da regularização do mercado de capitais no país, passam a ser uma alternativa viável para o Estado gerar recursos para o financiamento das políticas públicas em andamento.

Tabela 12: Brasil: Principais Ativos Financeiros Nacionais em \% (1964-1984)

\begin{tabular}{|l|r|r|r|}
\hline Tipos de ativos & \multicolumn{1}{|c|}{$\mathbf{1 9 6 4}$} & \multicolumn{1}{|c|}{$\mathbf{1 9 7 4}$} & $\mathbf{1 9 8 4}$ \\
\hline Monetários poder do & $\mathbf{9 2 , 2}$ & $\mathbf{4 2 , 9}$ & 10,8 \\
\hline $\begin{array}{l}\text { Papel-moeda em } \\
\text { público }\end{array}$ & 20,9 & 7,1 & 2,6 \\
\hline Depósitos à vista & 71,3 & 35,8 & 8,2 \\
\hline Não-Monetários & $\mathbf{7 , 8}$ & $\mathbf{5 7 , 1}$ & $\mathbf{8 9 , 2}$ \\
\hline Depósitos de poupança & - & 9,9 & 26,0 \\
\hline Depósitos a prazo & 2,5 & 11,5 & 16,2 \\
\hline Letras de Câmbio & 4,0 & 14,6 & 6,4 \\
\hline Letras Imobiliárias & - & 2,9 & 0,0 \\
\hline Títulos da dívida pública & 1,3 & 18,2 & 40,6 \\
\hline TOTAIS & 100,0 & 100,0 & 100,0 \\
\hline
\end{tabular}

Fonte: Banco Central do Brasil; adaptado de Teixeira (2000:40). 
Há uma diminuição expressiva dos chamados "haveres monetários" no sistema financeiro nacional, no decorrer dos anos posteriores à Reforma Bancária. O que importa destacar é que este aumento expressivo da utilização de títulos públicos é em grande parte fruto da própria modernização do sistema financeiro nacional: a partir da constituição do mercado de capitais no Brasil, o Estado brasileiro (principalmente a União, mas também alguns Estados da Federação e Prefeituras) passa a "emitir papéis" (títulos da dívida pública) para financiar as políticas públicas de modernização de sua base técnica e organizacional. Os títulos da dívida pública passam de 1,3\% dos totais desses haveres em 1964, para quase a metade deles $(40,6 \%)^{78}$.

Poderíamos nos perguntar, a partir destas novas modalidades de funcionamento do sistema financeiro brasileiro: como as técnicas novas introduzidas nas operações bancárias, nos sistemas de transmissão de informações, repercutiram na ação dos bancos brasileiros? Quais as principais alterações no padrão de comportamento das instituições públicas de concessão de crédito?

\footnotetext{
${ }^{78}$ Do ponto de vista estritamente financeiro, estes novos tipos de ativos que passam a compor os conteúdos do território assumem uma proporção cada vez mais importante por dois principais motivos: a) em sua grande maioria, por incorporarem a cláusula de correção monetária, têm incidido sobre eles (como já comentado) remuneração em juros com taxas positivas; e b) essa situação, por seu turno, dava aos ativos não-monetários bastante liquidez, o que tornava-os ainda mais interessantes aos agentes econômicos, reforçando um círculo virtuoso de procura e valorização dos mesmos.
} 
Pode-se dizer que duas das principais repercussões concretas deste novo sistema financeiro na ação bancária dizem respeito à organização e ao alcance da atividade financeira nacional. No que diz respeito à organização do sistema financeiro, é intensificado o processo de "concentração bancária" neste período; no que tange ao alcance deste sistema de ações, é formado em definitivo um "mercado nacional de crédito"(TEIXEIRA, 2000:54 e ss.).

Além de ter sido possibilitada pela nova base técnica do território, a diminuição do número de instituições atuantes no País foi também resultado de uma "política consciente do governo em favor da concentração bancária"(DE CASTRO, 1981:81). Assim como no período de ação da Superintendência da Moeda e do Crédito (antes de 1964-65, portanto), o Governo Federal entendia que essa concentração elevaria as chamadas "economias de escala" nos Bancos (BOUZAN, $1972)^{79}$. Neste período, várias instituições são adquiridas ou se fundem com bancos maiores, principalmente aqueles com sede em São Paulo, como mostram os estudos de Roberto Lobato Corrêa (1989; 1989, 2006).

Além do fenômeno da concentração bancária, data das décadas de 1960 e 1970 a formação dos primeiros bancos privados de dimensão nacional (CORRÊA, 1989; DIAS, 1995; GOMES, 2005), com destaque para o caso do Bradesco S/A. Assim, podemos falar que é formado um mercado nacional de crédito, "levando praticamente à extinção os grupos financeiros, ou os capitais bancários, caracteristicamente regionais ou estaduais"(TEIXEIRA, 2000:54). Como argumentam ainda Tavares e Carvalheiro (1985:85), "desde o final de 1964, o fato mais notável que envolve o conjunto dos bancos comerciais foi o desaparecimento de uma série de estabelecimentos pequenos e médios, absorvidos por bancos maiores".

\footnotetext{
79 Segundo Ary Bouzan (1972:61), “Economias de escala podem ser definidas como a redução que a empresa obtém no seu custo médio mínimo de produção por unidade de tempo, quando altera as dimensões de sua estrutura produtiva". Já Natermes Teixeira (2000:59) lembra que as Autoridades Monetárias da época acreditavam que maiores "economias de escala" trariam diminuição dos "custos operacionais dos bancos"; com essa diminuição de custos, por seu turno, "haveria possibilidade de ocorrência de taxas de juros bancários mais baixos".
} 
Faz-se mister frisar ainda que, concomitantemente à diminuição do número de instituições bancárias, há um aumento expressivo da quantidade de agências bancárias instaladas no território nacional. Portanto, uma menor quantidade de atores não significou uma diminuição da rede bancária para drenar os recursos gerados no território.

Tabela 13: Brasil: Evolução do No. de Bancos e de Agências Bancárias (1964-1980)

\begin{tabular}{|l|r|r|r|}
\hline & 1964 & \multicolumn{1}{|c|}{$\mathbf{1 9 7 1}$} & \multicolumn{1}{|c|}{1980} \\
\hline I. Número de Bancos & 329 & 162 & 90 \\
\hline II. Número de agências & \multicolumn{4}{|c|}{} \\
\hline 1. Banco Central & - & - & 10 \\
\hline 2. Banco do Brasil & 579 & 746 & 1.138 \\
\hline 3. Bancos comerciais oficiais & & 1.478 & 2.795 \\
\hline 4. Bancos comerciais privados & 6.138 & 5.615 & 7.405 \\
\hline 5. Totais & 6.717 & 7.839 & 11.348 \\
\hline
\end{tabular}

Fonte: Banco Central do Brasil; adaptado de Goldsmith (1986:382)

No período que vai dos anos de 1964 a 1980, há um acréscimo de 4.631 agências no território brasileiro. Das 6.717 agências bancárias existentes em 1964, o território passa a contar com 7.839 (em 1971), para chegarmos ao ano de 1980 a 11.348 agências. A partir dos dados coligidos por Raymond Goldsmith [1986:382), é possível entendermos melhor o que significou o processo de concentração bancária: de 329 Bancos existentes em 1964, passam a ser em 1971 apenas 162, para chegarmos ao ano de 1980 com 90 bancos no território. Houve, portanto, expressiva "redução no número de pessoas jurídicas bancárias", para usar a expressão de Ary Bouzan (1972).

Importa destacar que a concentração dos atores bancários só não é maior em função da existência dos bancos oficiais (estaduais e federais). Estes, como vimos, ganham uma importância ímpar no financiamento das novas infra-estruturas construídas no território durante as décadas de 1970 e 1980, e contrabalançam o poder adquirido por instituições como o Bradesco e o Itaú (que passam a se constituir em bancos verdadeiramente nacionais nessa época).

A manutenção de uma rede de bancos oficiais no território brasileiro era uma garantia de que as políticas públicas poderiam ser implementadas através da 
utilização de suas topologias e capacidades organizacionais instaladas. A análise da ação do BNDE, do Banespa e a da Caixa Econômica do Estado de São Paulo pode ser bastante elucidativa para análise da relação das finanças com o território brasileiro neste período de nossa história.

\subsection{O papel do BNDE: reforço dos circuitos industriais}

A história do Banco Nacional de Desenvolvimento Econômico (BNDE) neste período da creditização e integração do território se confunde em grande parte com a implementação do II Plano Nacional de Desenvolvimento (II PND). Na verdade, este Plano tinha nos bancos oficiais seus grandes aliados para a implantação de projetos de desenvolvimento do país. Na própria origem das políticas públicas, havia sido definida "orientação segundo a qual o sistema de bancos federais - e em particular o BNDE e o Banco do Brasil - atuará marcadamente no sentido da correção de desequilíbrios regionais, em reforço à ação do BNB e BASA" (LESSA, 1988, 1998:129).

Havia também neste período uma preocupação mais sensível em relação ao desenvolvimento do território como um todo, principalmente pelo entendimento de que era necessário diminuir e/ou acabar com os "desequilíbrios regionais" do país. Segundo a análise de Carlos Lessa $(1988,1998)$, a "engenharia financeira" dos circuitos públicos do dinheiro teria outra forma de organização, sendo que as principais novidades seriam:

1) através da atuação do Ministério do Interior, um novo enfoque basearia a ação federal, que "com a referência espacial, buscaria coordenar as ações de múltiplas agências federais e estaduais para, através de ação integrada, lograr a expansão, o crescimento e a transformação socioeconômica de áreas selecionadas"(LESSA, 1988, 1998:130);

2) do ponto de vista do financiamento, seria destinada "uma reserva de linhas de crédito no sistema de bancos oficiais para projetos das regiões de menor desenvolvimento"(LESSA, op. cit:: 130); 
3) no que diz respeito aos recursos fiscais, ocorreria ainda "um aperfeiçoamento dos sistemas de incentivos fiscais e da repartição institucional da receita tributária"(idem:130).

A partir deste quadro, o BNDE teria então uma função "setorial" (ligada à implantação de uma nova base técnica no território), mas também "territorial", preocupada com a distribuição dos financiamentos para o desenvolvimento das regiões menos dinâmicas do espaço nacional.

No caso da modernização dos sistemas de engenharia industriais, cabe destacar que o BNDE atuava, já em meados da década de 1970, concatenado com a rede de bancos públicos estaduais e regionais. Isto é, havia uma colaboração bastante estreita entre a ação do BNDE com os demais bancos oficiais (Bancos Federais Regionais e Bancos Estaduais). Esta colaboração se dava da seguinte forma: a) quando da necessidade de financiamento de obras/operações consideradas "médias e pequenas", os Bancos de Desenvolvimento regionais e/ou estaduais recebiam os repasses da verba federal via BNDE, e se responsabilizariam pelas operações; ou b) quando se tratasse de "grandes projetos"(LESSA, 1988, 1988:94), seria 0 próprio BNDE o avaliador/executor do projeto.

Essa ação do BNDE se torna ainda mais importante a partir do Governo Geisel, que o converte em "principal agente financeiro do II PND". Para isso, são necessários recursos, e a Lei Complementar de no. 19 acaba por transferir para o Banco os recursos da poupança compulsória gerada pelo Programa de Integração Social (PIS) e pelo Programa de Formação do Patrimônio do Servidor Público (PASEP). ${ }^{80}$

\footnotetext{
${ }^{80}$ Tanto o PIS quanto o PASEP foram mecanismos de "poupança compulsória", criados também no âmbito da Reforma Financeira de 1964/65, no intuito de angariar recursos para o financiamento de políticas públicas federais. O Banco Nacional da Habitação e o BNDE seriam seus principais canais de repasse. Esses "fundos sociais", portanto, podem ser assim sumariamente descritos: 1) Fundo de Garantia por Tempo de Serviço (FGTS): criado pela Lei 5.107 de 13.9.1966, seria constituído pela contribuição (de $8 \%$ da folha de salários) de todas as empresas submetidas à Consolidação das Leis de Trabalho; 2) Programa de Integração Social (PIS): seria formado pelos recursos (próprios) das empresas na proporção de $0,5 \%$ de seu respectivo faturamento, somado ao cômputo de 5\% do Imposto de Renda por elas anualmente devido; 3) Programa de Formação do Patrimônio do Servidor Público (PASEP): este, por sua vez, seria constituído por: a) contribuição de $2 \%$ da União sobre suas receitas correntes (deduzidas as transferências a outras entidades públicas); b) de $2 \%$ sobre as receitas dos Estados e Municípios (adicionando-se a estas as transferências recebidas da União); e finalmente, c) $0,8 \%$ das receitas orçamentárias e/ou operacionais (inclusive transferências da União) das autarquias, fundações, empresas públicas e empresas de economia mista (MARTINS, 1985:47).
} 
Como já pudemos mencionar, a "Doutrina da Segurança Nacional" - que balizava a estratégia de ação do Executivo Federal durante todo o período militar preocupava-se sobremaneira com o aumento da autonomia do país em relação ao seu desenvolvimento econômico. Neste sentido, são tidos como essenciais - ou estratégicos - a produção "dos insumos básicos e os bens de capital" em complemento às “indústrias de bens de consumo durável e à 'indústria' da construção civil"(LESSA, 1988, 1998:95).

O BNDE passa a ser um dos principais atores para a consecução desta busca de maior soberania econômica para o país. Para ilustrar esse aumento da importância do Banco, e como sua ação passa a repercutir no financiamento de vários setores econômicos, vejamos a tabela 14 abaixo.

Tabela 14: Brasil: Evolução das Operações Aprovadas Pelo Sistema BNDE Segundo o Setor Beneficiado (em Cr\$ milhões de 1981) (1972-1980)

\begin{tabular}{|l|r|r|r|r|r|}
\hline Atividades & $\mathbf{1 9 7 2}$ & $\mathbf{1 9 7 4}$ & \multicolumn{1}{c|}{$\mathbf{1 9 7 6}$} & \multicolumn{1}{c|}{$\mathbf{1 9 7 8}$} & \multicolumn{1}{c|}{$\mathbf{1 9 8 0}$} \\
\hline Mineração & $3.421,9$ & $16.947,4$ & $16.498,6$ & $9.923,4$ & $10.871,9$ \\
\hline Siderurgia & $12.414,5$ & $73.509,6$ & $171.941,8$ & $176.396,6$ & $108.848,2$ \\
\hline $\begin{array}{l}\text { Insumos básicos - } \\
\text { Metalurgia }\end{array}$ & $6.093,4$ & $18.731,7$ & $57.028,5$ & $36.847,4$ & $37.113,6$ \\
\hline Química e Fertilizantes & $13.202,4$ & $52.914,2$ & $133.132,2$ & $50.205,9$ & $26.818,9$ \\
\hline Celulose e Papel & $3.738,7$ & $41.075,1$ & $76.623,4$ & $21.839,3$ & $18.394,1$ \\
\hline $\begin{array}{l}\text { Produtos Minerais } \\
\text { Não-Metálicos }\end{array}$ & $8.506,3$ & $29.670,3$ & $59.681,8$ & $14.626,4$ & $19.668,1$ \\
\hline $\begin{array}{l}\text { Equipamentos } \\
\text { Mecânicos e Elétricos }\end{array}$ & $6.060,6$ & $28.517,1$ & $58.005,1$ & $15.952,5$ & $16.937,6$ \\
\hline $\begin{array}{l}\text { Equipamentos } \\
\text { Material de Transporte }\end{array}$ & $1.502,3$ & $10.932,3$ & $11.280,3$ & $4.373,0$ & $5.320,5$ \\
\hline $\begin{array}{l}\text { Indústria - Têxtil e de } \\
\text { Calçados }\end{array}$ & $11.053,4$ & $22.708,2$ & $15.771,6$ & $13.707,8$ & $19.292,8$ \\
\hline Produtos Alimentícios & $7.946,0$ & $19.336,4$ & $37.161,0$ & $16.942,3$ & $15.161,0$ \\
\hline Outras & $37.303,4$ & $26.453,7$ & $49.399,9$ & $27.868,4$ & $53.803,5$ \\
\hline
\end{tabular}

Fonte: BNDES; adaptado de RATTNER (1991:49) 
Conforme podemos observar, há um expressivo aumento dos investimentos do Banco, em áreas cruciais para a consolidação do meio técnico-científico informacional no país. Vale destacar ainda o aumento significativo dos investimentos nos circuitos da siderurgia (um dos pilares do II PND). De um montante de $\mathrm{Cr} \$ 12.414,5$ no ano de 1972 , estes circuitos passam a receber $\mathrm{Cr} \$$ $171.941,8$ (1976) e Cr\$176.396,6 (1978), aumentos de mais de $1.200 \%$, para os dois períodos.

Se na esfera federal a ação do BNDE pode ser entendida como um elemento de financiamento da renovação da base técnica do território, na esfera estadual também se tornavam cada vez mais importantes as políticas implementadas pelos bancos oficiais estaduais. No Estado de São Paulo, tanto o Banespa quanto a Caixa Econômica passam por transformações expressivas, com repercussões diretas para os usos possíveis do território na região.

\subsection{A ação do Banespa: uma relação mais orgânica com o território}

Assim como nos demais bancos estaduais do país, realizou-se no Banespa uma significativa modernização de sua estrutura organizacional a partir do final da década de 1960. Tanto as infra-estruturas físicas (rede de agências, automação bancária) quando as atividades administrativas da instituição foram bastante transformadas no período.

As mudanças técnicas introduzidas visavam primordialmente a "racionalização da burocracia" da instituição, lembra-nos Fernando Costa (1988). Inicia-se também no Banco um processo de automação, tendo sido o aparelhamento eletrônico das agências aumentado e modernizado. É instalada uma nova Central de Processamento de Dados, que figurava então entre as maiores e melhores da América Latina. "Devido à importância da rede de comunicações em seu sistema bancário de caráter nacional, foi instalada uma central de telex, um sistema de 
comunicação pelo rádio, entrelaçando todas as suas agências no país, além do equipamento PABX, e novas linhas telefônicas diretas"' (COSTA, 1988:334).

Essa modernização dos sistemas técnicos permite ainda a implantação de uma série nova de processos contábeis, e de oferecimento de produtos aos clientes do Banco. Também a topologia da instituição é alterada, já que se configura uma nova regionalização das agências. Buscando uma otimização do controle das informações - local e regionalmente geradas - foram designadas "concentrações regionais" do Banco no interior do Estado, tendo como finalidade o contato direto com as entidades de classe e os produtores de cada região, além de procurar " otimizar as relações Banco-clientes" (COSTA, 1988:334).

Em 1966, contando com 120 agências, o Banespa ambicionava a expansão de suas agências para um número maior de municípios, tanto em São Paulo, como nos demais Estados da federação ${ }^{81}$. A principal justificativa desta difusão espacial de suas atividades era a necessidade de expansão do crédito agrícola, já que o Banespa possuía também a "função de fomentador da agropecuária paulista"(COSTA, 1988:334).

O incremento da produtividade no campo, gerado pela especialização e modernização das áreas cultivadas, aumentava gradativamente a importância dos financiamentos agrícolas do Banco. Com relação à sua "Carteira de Crédito Rural", é possível dizer que estas operações alcançaram um valor máximo relativo no ano de 1975, segundo Fernando Costa (COSTA, 1988:389).

\footnotetext{
${ }^{81}$ A partir do ano de 1964, foram adquiridos alguns Bancos fora de São Paulo, para efeito da ampliação da rede de agências do Banespa. A aquisição de outros bancos era a única forma de expansão da rede de captação bancária, já que o mecanismo de concessão de cartas-patente (que permitia a abertura de novas agências bancárias) não era, no ano de 1964, passível de ser utilizado. Entre as instituiçõos adquiridas, constam: a) Banco Cordeiro, com sede em Cordeiro (R)); b) Banco do Pará, com sede em Belém (PA); c) Banco de Crédito Pessoal (com sede no então estado da Guanabara - RJ), no ano de 1964; d) Banco Nacional da Lavoura e Comércio (adquirido em 1967). Foram somadas às agências que já estavam sob comando do sistema de ações do Banespa outras 72. As exceções - em relação à abertura de agências novas por parte do Banco - foram conseguidas em função de uma combinação particular de fenômenos: no ano de 1967, foram permitidas a construção de agências nas cidades em que grandes infra-estruturas estavam sendo construídas, como por exemplo as usinas hidrelétricas de Urubupungá, Ilha Solteira e Pedregulho (Furnas) (COSTA, 1988:335).
} 
Relata ainda o autor (COSTA, 1988:389) que "a partir de 1982, os financiamentos à produção de alimentos básicos, principalmente milho, arroz e feijão, tiveram maior evolução nessa carteira". Daí ser possível afirmar que o Banco era um produtor de "solidariedades orgânicas" (SANTOS, 1996) na região, já que os cultivos financiados eram basicamente voltados para as necessidades alimentares mais básicas da população do Estado.

Outro aspecto que nos permite falar da formação de solidariedades orgânicas pela ação do Banespa, diz respeito tanto à distribuição "setorial" quanto "territorial" de seus recursos. No ano de 1969, por exemplo, as atividades industriais foram responsáveis por cerca de 16,1\% dos depósitos do Banespa, mas receberam cerca de $47,5 \%$ dos empréstimos totais do Banco. Já os produtores agrícolas depositaram $5,4 \%$ dos totais, e tomaram emprestado cerca de $20,0 \%$ do volume de recursos. O comércio, por sua vez, depositou $9 \%$ dos recursos do ano, e tomou emprestados cerca de $14,9 \%$ deles.

A situação se invertia nos casos do público em geral (que depositava cerca de 24,3\% da massa de recursos, e emprestava apenas 3,4\% ) e do Poder Público, já que este contribuía com nada menos que $45,2 \%$ dos depósitos e absorveu apenas 14,2\% dos empréstimos (COSTA, 1988:383). Em função destes dados (que se repetem para outros anos da ação do Banespa), é possível asseverar que a ação do Banco drenava recursos de sistemas superavitários e "irrigava" atividades econômicas dinâmicas, que contribuíam para o desenvolvimento do Estado de São Paulo como um todo.

Processo semelhante era passível de ser visto também em relação à distribuição territorial dos recursos do Banco. Em 1969 as agências localizadas na Grande São Paulo captaram cerca de $67,7 \%$ dos depósitos totais, cabendo às do interior do Estado cerca de 25,6\% (os restantes 7,7\% originaram-se das agências forâneas). O destino final dos empréstimos, por sua vez, teve a seguinte distribuição: a 
Grande São Paulo recebeu 53,2\%, o interior do Estado cerca de $36,7 \%$ e outros Estados cerca de 10,1\% (COSTA, 1988:383).

A partir destes dados, é possível afirmar que a ação do Banespa tinha um caráter mais distributivo, "horizontalizador". Isto é, sua ação procurava financiar todos os circuitos geográficos (industriais, agrícolas, de comércio), assim como procurava desconcentrar geograficamente esse financiamento. É também Fernando Costa que nos lembra que a ação do Banco "procurou melhor aproveitamento entre zonas de diferentes poderes aquisitivos" (COSTA, 1988:383).

\subsection{A Caixa Econômica do Estado de São Paulo e a racionalização da topologia bancária}

O outro principal ator financeiro oficial de São Paulo era a Caixa Econômica do Estado. A Caixa mantinha no período a posição de maior instituição estadual de poupança, e só era ultrapassada pela Caixa Econômica Federal. Como mostra a tabela abaixo, vemos que o Estado de São Paulo concentrava ainda parcela expressiva dos depósitos de poupança em território brasileiro.

Tabela 15: Brasil: Distribuição Regional dos Depósitos em Caixas Econômicas (em \% ) [1964-1979)

\begin{tabular}{|l|r|r|r|}
\hline & \multicolumn{1}{|c|}{$\mathbf{1 9 6 4}$} & \multicolumn{1}{|c|}{$\mathbf{1 9 7 2}$} & \multicolumn{1}{|c|}{$\mathbf{1 9 7 9}$} \\
\hline Região Norte & 1,5 & 1,0 & 1,2 \\
\hline Região Nordeste & 7,4 & 6,5 & 7,8 \\
\hline Pernambuco & 3,3 & 1,4 & 1,8 \\
\hline Bahia & 1,3 & 1,6 & 2,1 \\
\hline Região Sudeste & 69,6 & 70,1 & 71,0 \\
\hline São Paulo & 42,0 & 45,6 & 45,5 \\
\hline Caixa Estadual & 28,1 & 24,9 & 20,2 \\
\hline Caixa Federal & 13,8 & 20,7 & 19,3 \\
\hline Rio de Janeiro & 23,1 & 18,9 & 19,5 \\
\hline Minas Gerais & 3,6 & 4,6 & 4,9 \\
\hline Região Sul & 8,9 & 14,8 & 12,6 \\
\hline Rio Grande do Sul & 6,1 & 9,3 & 7,0 \\
\hline Região Centro-Oeste & 8,4 & 7,7 & 4,6 \\
\hline Região Concentrada & 78,5 & 84,9 & 83,6 \\
\hline BRASIL & 100,0 & 100,0 & 100,0 \\
\hline Fo & & & \\
\hline
\end{tabular}

Fonte: Banco Central do Brasil; adaptado de Goldsmith (1986:393) 
O quadro da distribuição regional dos recursos depositados em Caixas Econômicas no Brasil permite, em primeiro lugar, identificar uma significativa concentração deste tipo de finança na região Sudeste do País (com $71 \%$ dos totais em 1979). Podemos também atentar para a importância que adquire a Região Concentrada (Regiões Sul e Sudeste) no controle da poupança no país: de um total de 78,5\% em 1964, passa a abarcar cerca de 83,6\% em 1979.

Esta importância da Região Concentrada pode ser creditada em grande parte à ação da Caixa Econômica do Estado de São Paulo, como mostram mesmo os dados da tabela 15. As quantidades depositadas em sua rede de agências nunca foram menores que $20 \%$ dos totais depositados em todo o país, para o período. Quais seriam os fatores que estariam na base dessa importância da Caixa Econômica do Estado de São Paulo? Quais as novidades do período histórico que ela consegue assimilar, para se tornar um ator tão significativo no contexto regional e nacional?

Um primeiro aspecto que podemos destacar, no sentido de entender melhor a ação da Caixa Econômica, diz respeito à modernização institucional pela qual passa a instituição. No ano de 1974 ela se constitui numa companhia com capital aberto, passando a ser denominada Caixa Econômica do Estado de São Paulo S/A. A instituição incorpora, assim, uma nova forma organizacional que passou a ser permitida pela chamada "Reforma Bancária", como vimos no item 6.2.

Além do aspecto organizacional, podemos destacar também a questão da topologia da instituição, que parece ter influenciado decisivamente no desenvolvimento de suas possibilidades de atuação. Das 454 agências existentes no ano de 1964, a Caixa Econômica passa a contar com 757 no ano de 1988. São 305 novos fixos geográficos instalados na região, que passam a trabalhar para promover a intermediação financeira no Estado.

A bem da verdade, estes 305 novos fixos geográficos não são compostos apenas de agências bancárias. Deste total, nada menos que 283 são Postos de Atendimento Bancário (os chamados $P A B$ 's), que vêm alterar a natureza da rede de captação de depósitos da Caixa. Esta expressiva utilização dos PAB's pela Caixa 
(que compõem cerca de $93 \%$ dos novos pontos instalados no período 19641988) é na verdade uma tendência do período, ao menos para os bancos oficiais. A partir da década de 1970, praticamente todas as instituições públicas mudam a qualidade da cobertura bancária: de uma rede fundada só em agências, passam a ser utilizados também os chamados "Postos de Atendimento Bancários" (PAB's).

Este fenômeno, segundo Ary Bouzan, tem no aumento da necessidade de "eficiência das agências" (BOUZAN, 1972:89) uma de suas causas principais. Além das novas técnicas da automação bancária terem permitido uma menor quantidade de funcionários necessários para a manutenção de um ponto de atendimento bancário (JINKINGS, 2002), o próprio aumento da concorrência entre as instituições obriga a uma mudança da qualidade da rede de captação de depósitos dos bancos. Basicamente, as instituições financeiras começam a se preocupar mais com a relação entre quantidade de depósitos/rede de agências. De maneira resumida, essa "eficiência" necessária estava fundada no seguinte raciocínio:

“(...) cada agência acrescida à rede de um banco envolve custos adicionais e receitas adicionais. Os custos estão representados pelo pessoal, pelas máquinas, aluguéis, impostos, etc. As receitas são determinadas pelas aplicações que a agência fará diretamente ou permitirá ao banco no seu conjunto fazê-las. Essas aplicações, de sua parte, dependem principalmente dos depósitos que ela consegue arrecadar"(BOUZAN, 1972:89).

As mudanças ocorridas na rede de atendimento da Caixa Econômica parecem ser bastante representativas deste processo de aumento de "eficiência bancária". Os primeiros $P A B$ 's da Caixa aparecem já no ano de 1976; mas é entre os anos de 1977 e 1978 que ganha força sua difusão, superando o ritmo de criação de agências tradicionais. Vale destacar que a maior parte dos PAB's é instalada em repartições públicas. Mais especificamente, os Postos são locados preferencialmente em Fóruns e Tribunais da Justiça Estadual, na tentativa de aproximar a estrutura de captação de fundos da Caixa dos fluxos de recursos transitados por estas instituições públicas ${ }^{82 .}$

${ }^{82}$ No caso dos Fóruns de Justiça, os PAB's servem, desde esta época, para a prestação de serviços ao funcionalismo de cada comarca, como também são especializados na gerência de valores envolvidos em "ações judiciais" de vários tipos. O exemplo mais comum é o de pagamento/recebimento de pensão alimentícia. Passam ainda pelos PAB's instalados em Fóruns Judiciais vários outros tipos de depósitos, ligados a litígios e processos que tramitam no sistema judiciário. 
Do que foi exposto em relação à ação da Caixa Econômica do Estado de São Paulo no período em tela, podemos destacar ao menos três características desta ação que indicam como os conteúdos do território influenciam a atividade financeira:

a) a partir das novas tecnologias informacionais (redes de telex e de telefonia, dos aparelhos de automação bancária), e das novas infra-estruturas de transporte do território, as redes de agências adquirem uma flexibilidade maior para a instalação de seus pontos ou fixos geográficos; assim, passam a localizá-las onde é possível uma melhor drenagem de depósitos para sua rede; no "período técnico" do território, a distribuição da rede de agências dependia bastante da rede ferroviária, como vimos;

b) a Caixa Econômica do Estado de São Paulo mantém um padrão de localização de seus fixos geográficos próximos (ou dentro) das demais instituições públicas; esse já era o caso nas décadas de 1940 e 1950, quando se fixavam as agências junto aos postos de coletoria de impostos. Essa proximidade física e institucional melhora as possibilidades de captação de recursos movimentados pelas instituições públicas no Estado;

c) além de ter sido transformada a forma de organização da Caixa (passa a ser uma "sociedade anônima"), é alterada ainda a qualidade de sua rede de captação de depósitos. De um padrão fundado eminentemente em agências bancárias, passam a ser utilizados os chamados Postos de Atendimento Bancário (os PAB's). Fruto do aumento da automação bancária e da concorrência entre as instituições, os PAB's permitem uma capilarização maior da rede de coleta das instituições bancárias oficiais no território, aumentando a produtividade espacial (SANTOS, 1996:197) ${ }^{83}$ da atividade financeira no Estado.

Ainda com relação à produtividade espacial que esta racionalização da rede de agências da Caixa Econômica permite, vale lembrar que se trata - sempre - de uma produtividade seletiva, isto é, que não atinge todos os pontos do território de

83 A "produtividade espacial" está relacionada com a capacidade dos lugares de oferecerem "maior rentabilidade aos investimentos"(SANTOS, 1996:197). Ainda segundo Milton Santos (1996:197-198), "assim como se fala de produtividade de uma máquina, de uma plantação, ou de uma empresa, podemos, também, falar de produtividade espacial ou produtividade geográfica, noção que se aplica a um lugar, mas em função de uma determinada atividade ou conjunto de atividades". 
maneira homogênea. Tanto em função de sua configuração territorial, quanto de sua densidade técnica, e de seu contingente populacional, cada parcela do território vai conseguir abrigar (ou não) determinados vetores de modernidade.

Os Mapas 5 e 6, além de mostrarem a difusão dos Postos de Atendimento Bancário da Caixa Econômica no Estado e na cidade de São Paulo, também nos dão uma idéia aproximada da distribuição seletiva da rede de agências da Caixa na região. No caso do Mapa 5 (do estado), há regiões de maior densidade de agências e PAB's (por exemplo, ao redor da Região Metropolitana de São Paulo, assim como regiões de maior rarefação (principalmente no sul, na Região do Vale do Ribeira). O mesmo raciocínio vale para o Mapa 6, que mostra a distribuição da rede de pontos de atendimento no município de São Paulo; dos 58 fixos geográficos da Caixa Econômica, 23 estão concentrados no chamado "centro expandido" da cidade, isto é, a região que engloba os bairros do centro da cidade, assim como aqueles que se situam entre as marginais Tietê e Pinheiros ${ }^{84}$.

O recorte temporal dos mapas (realizado no ano de 1988) teve também a intenção de atentar para algumas mudanças que se inserem no uso financeiro do território a partir deste ano. Em 1988 é promulgada a nova Constituição Federal, que vai alterar sensivelmente os conteúdos normativos do território, incluindo aí os conteúdos que regulamentam a atividade financeira no país.

\subsection{As mudanças no âmbito da Constituição de 1988: novas normas bancárias e $o$ ambiente inflacionário}

A partir do ano de 1988 (com a promulgação da nova Constituição) é realizada uma "reorganização normativa, política, econômica e espacial"(DIAS, 2005:30) de nosso sistema financeiro e bancário. Uma série de medidas são tomadas pelas Autoridades Financeiras do país para modernizar o quadro legal que regulava a atividade financeira no território brasileiro.

${ }^{84}$ A rigor, o "centro expandido" da cidade de São Paulo se situa nos bairros que ficam entre as seguintes vias expressas: marginais Tietê e Pinheiros, Avenida dos Bandeirantes, Avenida Tancredo Neves, Avenida Juntas Provisórias e Avenida Salim Farah Maluf. 


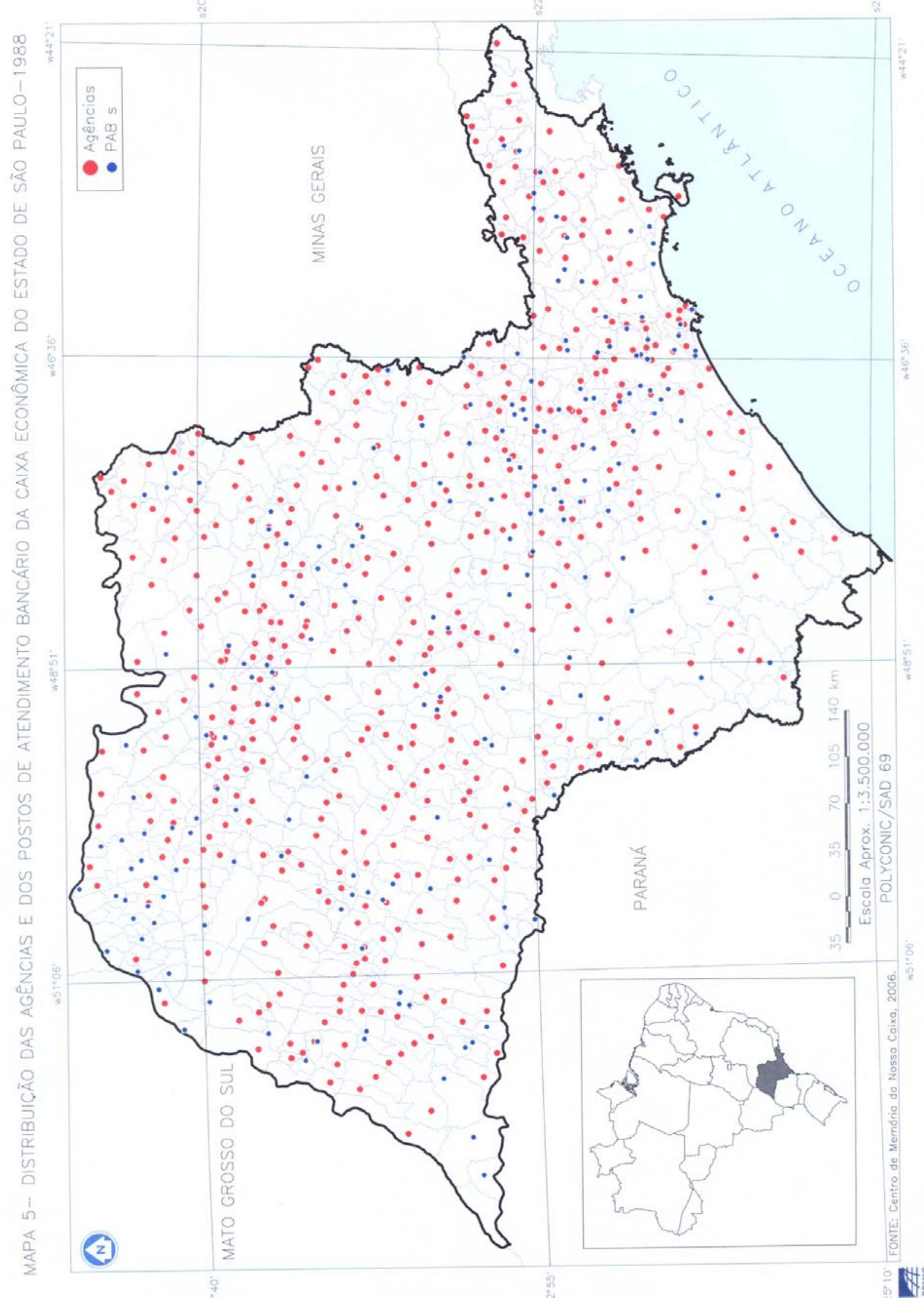


MAPA 6 - DISTRIBUICÃO DAS AGÊNCIAS E DOS POSTOS DE ATENDIMENTO BANCÁRIO DA CAIXA ECONÔMICA DO MUNICÍPIO DE SÃO PAULO-1988

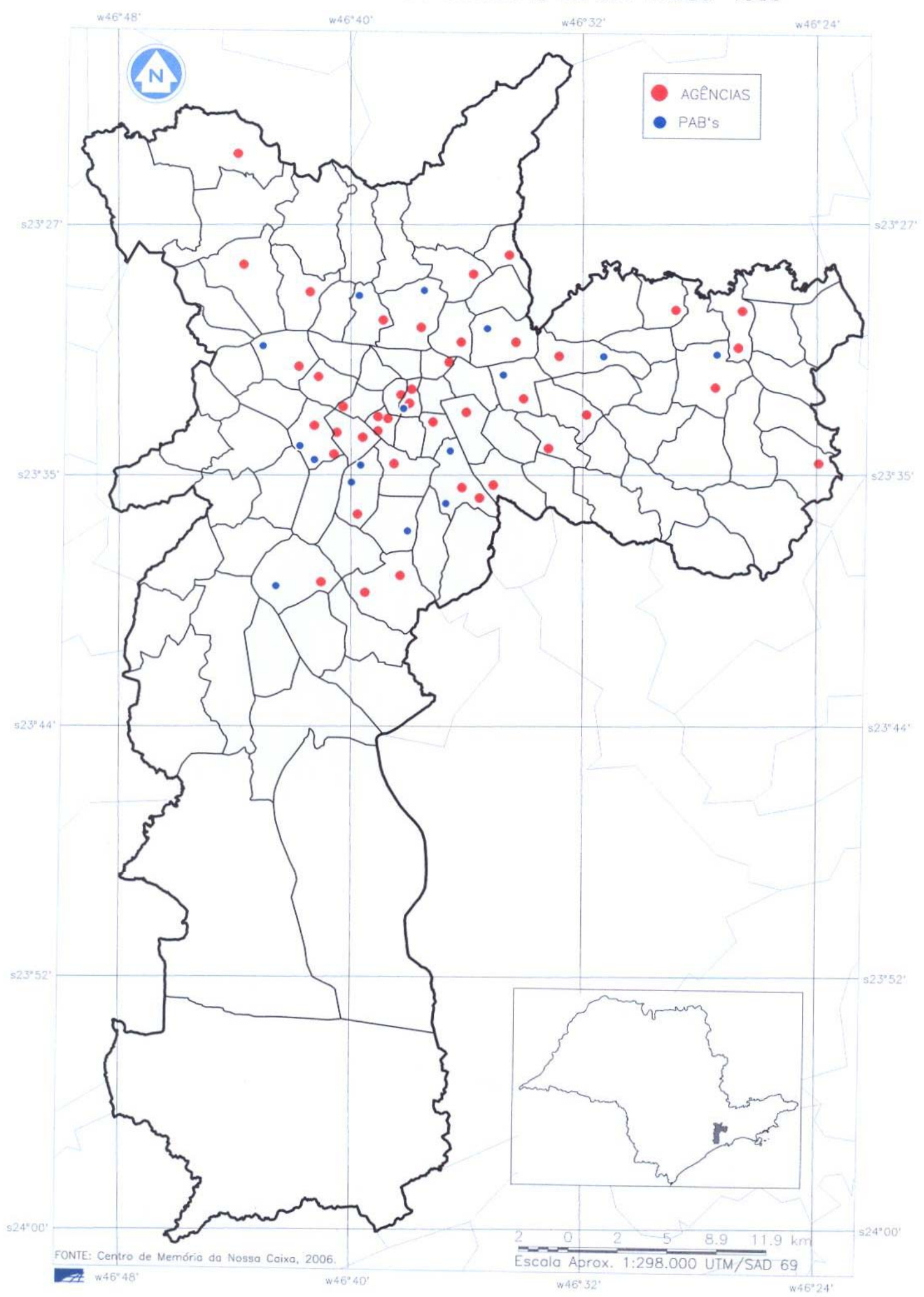


Talvez a principal novidade nos conteúdos normativos do território é aquela trazida pela Resolução 1.524 de setembro de 1988, do Conselho Monetário Nacional. Esta nova norma tem duas repercussões essenciais para o funcionamento do sistema bancário e financeiro. Em primeiro lugar, ela cria a figura jurídica dos "Bancos Múltiplos"85. Passa a ser permitido que atividades antes realizadas separadamente por corretoras de seguros, distribuidoras de títulos e valores, bancos de investimento, viessem a ser controladas por um Banco principal. Este tipo de organização permitida pela norma do $\mathrm{CMN}$, portanto, altera profundamente o espírito da reforma de 1964/65, que visava muito mais uma "compartimentalização" da ação das instituições financeiras. A criação dos Bancos Múltiplos concede mais poder aos atores financeiros, já que passa a ser permitido tanto o comando centralizado de outras instituições financeiras, como também é possível a partir dali que os Bancos controlem empresas de ramos industriais e de serviços.

Mas a Resolução 1.524 se reveste de grande importância também por suas conseqüências em relação à topologia bancária. A partir dela, é extinta a necessidade das "cartas-patente", para que fossem abertos novos pontos de atendimento do sistema bancário no território brasileiro. Ao contrário do que sempre ocorrera no território (desde a criação da SUMOC, em 1945), as Autoridades Monetárias perdem a prerrogativa da utilização das "cartas-patente" como forma de estabelecimento de políticas de planejamento da topologia bancária nacional.

Esta mudança normativa é bastante diferente (para não dizer oposta) ao espírito das sucessivas leis que regulamentaram a distribuição dos bancos no território. Se antes

${ }^{85}$ Segundo a definição do próprio Banco Central, "Os bancos múltiplos são instituições financeiras privadas ou públicas que realizam as operações ativas, passivas e acessórias das diversas instituições financeiras, por intermédio das seguintes carteiras: comercial, de investimento e/ou de desenvolvimento, de crédito imobiliário, de arrendamento mercantil e de crédito, financiamento e investimento. Essas operações estão sujeitas às mesmas normas legais e regulamentares aplicáveis às instituições singulares correspondentes às suas carteiras. A carteira de desenvolvimento somente poderá ser operada por banco público. O banco múltiplo deve ser constituído com, no mínimo, duas carteiras, sendo uma delas, obrigatoriamente, comercial ou de investimento, e ser organizado sob a forma de sociedade anônima. As instituições com carteira comercial podem captar depósitos à vista. Na sua denominação social deve constar a expressão "Banco" (Resolução CMN 2.099, de 1994)"(BANCO CENTRAL, 2006). 
havia um esforço para que não ocorresse uma concentração excessiva de agências em alguns pontos específicos do território, agora os bancos possuem maior liberdade para instalarem - sem critérios públicos - sua rede de agências. Deixada ao sabor das forças do mercado, a tendência para a distribuição dos fixos geográficos financeiros é a de se concentrar ainda mais no que poderíamos chamar de "espaços inteligentes" (SANTOS, 1993) do território, isto é, aquelas regiões em que o meio técnicocientífico-informacional aparece de forma mais densa e complexa ${ }^{86}$.

Estas duas alterações é que permitiram ao economista Carlos Vidotto [2005:72] dizer que ocorreu no ano de 1988 uma "mini-reforma do sistema bancário" brasileiro. Na verdade, desde a década de 1970, vinha sendo já realizada uma aglutinação de funções do sistema financeiro e bancário brasileiro em torno de alguns bancos comerciais principais. Mas "o sistema estava ainda legalmente segmentado", lembra-nos Roberto Troster (2004:11). A Resolução 1.524 do Conselho Monetário, ao permitir a formação dos Bancos Múltiplos, apenas normaliza esta situação. De acordo com a nova regulamentação, o sistema financeiro teria o seguinte modus operandi:

\begin{abstract}
“De um enfoque assentado na visão de um sistema financeiro formado por instituições especializadas, condicionadas pela regulamentação a praticarem uma faixa restrita de operações, tomou-se o rumo para um outro tipo, mais próximo do sistema constituído pelas chamadas "instituições universais". Neste, as instituições, embora diferenciadas entre si na organização funcional e administrativa, na condução dos negócios e na escala de operações, apresentam em comum $\mathrm{o}$ fato de, independentemente dessas diferenças, poderem oferecer todos os serviços financeiros." (Banco Central. 2006).
\end{abstract}

\footnotetext{
${ }^{86}$ A tendência para a concentração das atividades econômicas no espaço geográfico é um tema bastante estudado na geografia, mas também pela teoria econômica. Podemos dividir - de forma esquemática - em dois principais tipos de "tradição de pensamento econômico" o estudo da economia em relação à distribuição das atividades produtivas no espaço: a) de um lado se situa o entendimento de que a ação do Estado é danosa à organização econômica do espaço, pois ela impediria o livre funcionamento das forças de mercado; esta corrente, denominada também de "neo-clássica", acredita que as "forças de mercado" é que permitem uma alocação ótima dos fatores produtivos nas regiões econômicas. O principal formulador desta corrente de pensamento é o economista britânico Alfred Marshall; e b) por outro lado, há os pensadores que vêem a ação do Estado como necessária para a organização geográfica das atividades econômicas. Segundo essa visão, as forças de mercado são inerentemente concentradoras dos fatores produtivos (tanto do ponto de vista setorial, quanto das classes sociais, assim como da organização do espaço). Assim, a ação do Estado torna-se necessária para corrigir essas falhas de mercado, que levam - no caso da organização do espaço - a fenômenos como o da polarização regional, formação de externalidades negativas, entre outras disfunções realizadas pelo predomínio das forças privadas na economia. Os principais autores desta corrente de pensamento seriam François Perroux, Albert Hirschmann e Gunnar Myrdal. Ver PETRELLA (1972).
} 
Uma segunda conseqüência principal desse processo de desregulamentação do uso financeiro do território é gerada pelo artigo 192 da Constituição de 1988, que "estabelece que, a partir de então, não haveria mais barreiras de entrada no setor financeiro" (TROSTER, 2004:11), aumentando sobremaneira o número de bancos que atuavam no território.

Tabela 16: Brasil: Evolução do Número de Bancos no Território Brasileiro (1986-1995)

\begin{tabular}{|c|r|c|r|}
\hline Ano & Número & Ano & Número \\
\hline $\mathbf{1 9 8 6}$ & 105 & $\mathbf{1 9 9 2}$ & 234 \\
\hline $\mathbf{1 9 8 8}$ & 106 & $\mathbf{1 9 9 3}$ & 243 \\
\hline $\mathbf{1 9 8 9}$ & 179 & $\mathbf{1 9 9 4}$ & 246 \\
\hline $\mathbf{1 9 9 0}$ & 216 & $\mathbf{1 9 9 5}$ & 242 \\
\hline
\end{tabular}

Fonte: Banco Central do Brasil (vários anos); adaptado de TROSTER (2004)

Este aumento dos atores bancários se dá em grande parte a partir da entrada no sistema financeiro de "empresas comerciais e industriais", que criam seus próprios sistemas de ações financeiros, e passam a "ingressar e concorrer no sistema bancário", como nos lembra também a geógrafa Leila Dias (2005:47). Segundo ainda a autora, neste período várias sociedades corretoras e "financeiras" são também transformadas em bancos múltiplos, assim como "são criados novos bancos de pequeno e médio porte"(DIAS, 2005:48) no país.

Ao mesmo tempo que aumenta o número dos atores no sistema bancário, o processo de crescimento da rede de agências permanece relativamente estável. Das 16.016 agências existentes no ano de 1989, o território brasileiro passa a ter 16.009 agências em 1991, para chegar no ano de 1994 com 16.302, como mostra o estudo de Luiz Francisco de Paula $(1998)^{87}$.

\footnotetext{
87 Vale destacar ainda que neste subperíodo que se estende do ano de 1988 até 1994 (quando seria implantado o Plano Real), o processo de concentração do controle das finanças do território continuou vigoroso. No estudo de Antonio Chagas Meirelles ( $\mathrm{s} / \mathrm{d}$ ), vê-se através da variação dos "depósitos à vista" realizados no sistema bancário nacional que prossegue a tendência de diminuição do número de efetivos controladores do sistema. Para o autor (MEIRELLES, s/d:101), “Em dezembro de 1966, 17 bancos detinham $50 \%$ o valor dos depósitos à vista do sistema privado. Em 1974, com o aumento da concentração, apenas seis bancos detinham $50 \%$ dos depósitos à vista da rede privada. Esse quadro pouco se alterou desde então. Em 1991 , sete bancos detinham $50 \%$ do total de ativos".
} 
Após analisarmos as principais alterações nos conteúdos normativos, financeiros e na topologia bancária na década de 1980, faz-se necessário lembrar também que a lógica de funcionamento das instituições bancárias era, em grande parte, influenciada também pelo chamado "processo inflacionário", considerado uma dimensão importante da evolução econômica do país (RANGEL, 1963, 1986; DE PAULA, 1998).

No que diz respeito ao fenômeno da inflação, vimos que uma de suas influências no sistema bancário foi a de ter gerado a necessidade de abertura de novas agências bancárias por parte das instituições financeiras, desde ao menos a década de 1950. Através de um aumento da rede de captação, seria possível drenar poupanças locais, e manipulá-las a favor da instituição financeira em questão (PASSOS, 1973).

Na década de 1980, com o aprofundamento da crise financeira do Estado brasileiro (BELUZZO, 1984; GIAMBIAGGI e ALÉM, 1999) a inflação passa a ser a principal forma de lucro dos bancos. A intermediação financeira propriamente dita (isto é, a ação de receber depósitos e realizar empréstimos) deixa de ser o foco das instituições bancárias no País. O "ganho inflacionário" (CARVALHO, s/d:5 e seguintes ${ }^{88}$ é que pauta o funcionamento dos bancos.

É importante destacarmos que os mecanismos ligados à inflação eram os grandes "reguladores" da remuneração bancária, pois a partir do controle do processo inflacionário após o chamado Plano Real, o sistema bancário brasileiro vai passar por transformações expressivas, e parte significativa das instituições financeiras será incapaz de se adaptar ao novo ambiente criado.

A bem da verdade, a qualidade e a magnitude das mudanças introduzidas no uso financeiro do território em 1994 nos permite afirmar que uma ruptura no

88 O chamado "ganho inflacionário" se dava da seguinte forma: “Os bancos não pagam ao (sic) titulares destes recursos um rendimento que compense a corrosão de seu valor pela inflação, mas incluem essa compensação na taxa cobrada do tomador de empréstimos por eles financiados, e se apropriam da diferença” (s/d:5). 
processo histórico ocorrera, ao menos para a relação do território com as finanças. A partir do Plano Real, uma série de alterações nos conteúdos normativos, técnicos e organizacionais do território também se instala, com repercussões sensíveis para a organização da atividade financeira no País. 
No período de creditização e integração do território nacional, as finanças começam a ganhar uma autonomia maior na vida da nação, assim como nos usos possíveis do território brasileiro. Por creditização do território estamos entendendo esta necessidade premente de "capitais adiantados" que a expansão do meio técnico-científico no espaço geográfico exige (SANTOS, 1993; SANTOS e SILVEIRA, 2001). Fundamentalmente, o aumento da quantidade de capitais fixos (seja no meio agrícola, seja no meio urbano) obriga os agentes produtivos a buscarem recursos no sistema bancário para o desenvolvimento de suas atividades. Daí a finança, no seu sentido mais amplo, ter sido gradualmente erigida como uma das variáveis-chave do período que se inicia em 1964.

No que diz respeito à integração material do território, vemos que os transportes são organizados numa base mais ubíqua e capilarizada, e a vida de relações das cidades brasileiras ganha um aumento de intensidade em seus aspectos regionais, e permite ainda que muitas cidades desta rede ensejem uma vida de relações de alcance nacional, e mesmo internacional. Assim, é permitida uma "ampliação", ou um "alargamento dos contextos"(SANTOS, 1996:202 e ss.) ${ }^{89}$.

Essa rede urbana, por sua vez, fomentou um mercado interno demandador de consumos novos, de variados tipos. São exemplos destas novas necessidades os bens de consumo duráveis e não-duráveis, bens de capital, assim como os chamados consumos "imateriais", tipicamente urbanos: consumo de serviços de saúde, de lazer, de cultura etc. A entrada mais expressiva de empresas multinacionais nos circuitos industriais e agrícolas do território se dá em grande

\footnotetext{
${ }^{89}$ Para Milton Santos, com a integração material e imaterial dos territórios, são dadas novas possibilidades de fluidez de bens, mercadorias, pessoas, informações, multiplicando o número e a complexidade das conexões entre os lugares. Destarte, "passamos de uma autonomia relativa entre subespaços a uma interdependência crescente; de uma interação local entre sociedade regional e natureza a uma espécie de socialização capitalista territorialmente ampliada; de circuitos com âmbito local, apenas rompidos por alguns poucos produtos e alguns poucos produtores, à existência predominante de circuitos mais amplos. $\mathrm{O}$ aprofundamento da divisão do trabalho impõe formas novas e mais elaboradas de cooperação e de controle, à escala do mundo, onde é central o papel dos sistemas de engenharia concebidos para assegurar uma maior fluidez dos fatores hegemônicos e uma maior regulação dos processos produtivos, por intermédio das finanças e da especulação"(SANTOS, 1996:203).
} 
parte para suprir estas novas demandas. O sistema de ações do território já não é mais eminentemente local ou regional; ao contrário, ele é cada vez mais nacional, e gradativamente também mais internacional.

Em relação ao aumento dos consumos "imateriais" do País, é factível afirmar que ele tem relação direta com uma novidade técnica do período: a instalação dos sistemas de engenharia ligados às telecomunicações no território. As técnicas da telecomunicação vão expandir as possibilidades de uso do espaço, pois elas permitem uma aceleração do deslocamento de informaçôes no País. A bem da verdade, as técnicas das telecomunicações e da informação possuem elevada "convergência", como nos ensina Milton Santos (1996:146).

É cada vez mais comum e banalizado o deslocamento de informaçôes no sentido mais geral (transporte de bits, mensagens, imagens, vozes), mas também em seu sentido político: as informações comportam ainda ordens e decisóes, e vão contribuir para que uma nova divisão territorial do trabalho se instale nesta rede urbana nacional.

Concomitantemente a esta expressiva transformação da base material da nação se processa ainda uma modificação profunda em seus conteúdos normativos. Os dois principais eventos desta modificação são as Constituintes promulgadas no período (nos anos de 1964 e 1988). No que toca ao uso financeiro do território, a chamada "Reforma Bancária", consubstanciada entre os anos de 1964/1965 foi o evento mais significativo. Conforme já mencionado, a Reforma Bancária constitui uma Autoridade Monetária no país, centralizando ainda mais o comando da organização financeira do território.

Mas as duas principais novidades do período, decorrentes da Reforma, são a formação do mercado de capitais e a instituição da correção monetária nos títulos públicos negociados neste mercado. A instituição da correção monetária aumentou sensivelmente a rentabilidade dos negócios financeiros no País, e concedeu um 
vigor maior à drenagem da poupança nacional realizada pela rede bancária instalada. Não menos importante parece ter sido a normatização do mercado de capitais no país. Com ela, outros atores financeiros surgem, e uma nova estrutura de propriedade das empresas instaladas no território brasileiro é tornada possível. Passa a ser possível a ação dos chamados "acionistas" no comando das atividades produtivas do território. Sendo não mais que um "simples capitalista monetário" (HILFERDING, 1909, 1985:36), a figura do acionista diminui a ligação orgânica dos sistemas de ações com os sistemas de objetos produtivos instalados no território. O mercado de capitais, neste sentido, pode ser considerado como um poderoso mecanismo de "desencaixe" (GIDDENS, 1991) ou de "desancoragem" ("entankerung"), na terminologia de Benno Werlen (1999).

Estas novas formas de uso do território possibilitam que outros arranjos regionais sejam realizados, que novas solidariedades geográficas se dêem entre os atores, os lugares e as regiões. Quais delas nos permitem falar na instalação de "solidariedades orgânicas" no território? E quais dinâmicas se aproximariam mais da conformação de "solidariedades organizacionais" no País?

No que diz respeito à organização do espaço agrícola, pode-se afirmar que a expansão do meio técnico-científico, incluída a creditização desse uso do território, se constitui num processo de formação de solidariedades organizacionais no espaço nacional. As unidades produtivas cada vez menos dependem dos dados da economia local (mercado consumidor, fornecedores) para se reproduzirem. Tanto em função da necessidade de insumos provenientes de circuitos externos (sementes selecionadas, fertilizantes, equipamentos), mas também em função da necessidade do crédito agrícola, uma racionalidade organizacional se instala em cada área de cultivo que conhece um modernização de suas técnicas agrícolas. Se a produção em questão tiver como destino final o mercado externo, significa uma adesão ainda maior da dinâmica local a dinâmicas determinadas alhures. A produção agrícola, neste sentido, depende cada vez menos de seus contextos locais e regionais; a atividade de cultivo torna-se um dos 
processos dentro de um "circuito espacial de produção" (SANTOS, 1985, 1988a; MORAES, 1985) bem mais amplo, e bastante dependente da finança ${ }^{90}$.

No caso dos conteúdos industriais do território, é possível afirmar que a modernização da base produtiva aumentou as possibilidades de desenvolvimento mais autônomo do País. Esse desenvolvimento mais "introvertido" é resultado tanto da diversificação das atividades industriais, assim como pela formação de um sólido sistema de engenharia voltado para a produção de bens de capital. Porém, o controle por parte de multinacionais do processo de produção nos circuitos mais rentáveis da indústria (como é o caso das indústrias de bens de consumo duráveis e não-duráveis) engendra também solidariedades organizacionais no país. O que pode ser dito dos conteúdos do território ligados às finanças?

O sistema bancário brasileiro foi talvez o principal beneficiário da introdução dos sistemas técnicos informacionais no território. Dada a enorme quantidade de dados e mensagens que os atores financeiros geram e gerenciam, a passagem de um meio técnico-científico, para um meio técnico-científico informacional aumentou sensivelmente a produtividade e a eficiência das ações bancárias no território. Tanto no que diz respeito ao "fazer cotidiano" das agências, quanto na formação das primeiras redes bancárias nacionais, as técnicas da informação permitiram aos bancos e demais atores financeiros o início de sua hegemonia no comando do território.

As técnicas bancárias tornam os ativos financeiros muito mais mobilizáveis, através da "titularização" da riqueza nacional. O surgimento de novos produtos financeiros atrai os capitais das demais atividades produtivas à esfera da finança. Se inicia neste período uma maior "instabilidade do território" (SANTOS e SILVEIRA, 2001; SILVEIRA, 2002), dada a grande fluidez e mobilidade que o dinheiro adquire.

90 O estudo da geógrafa Paula Borin (2002) traz uma detalhada análise dos "circuitos espaciais" da produção de malhas no interior do estado de São Paulo. 
A concentração bancária ganha mais fôlego, apesar do aumento do número de instituições financeiras ao final do período descrito. A diminuição dos centros de comando das finanças privilegia algumas cidades do território, que passam a abrigar a maior parte das sedes das instituições financeiras nacionais. São Paulo, como notam os geógrafos Roberto Lobato Corrêa $(1989 ;$ 1989, 2006), Milton Santos (1993, 1994c), Leila Dias (1995) e Adriana Bernardes (2001) passa a ser neste período o centro de comando informacional e financeiro do país. Os bancos regionais e locais são gradualmente extintos, ou passam a ser comandados pelas instituições financeiras de porte nacional.

O comportamento de alguns atores do sistema financeiro nacional acaba por permitir a manutenção de solidariedades orgânicas no uso financeiro do território. É o caso da ação dos bancos oficiais que, como vimos, mantêm políticas de desenvolvimento regional mais concatenadas com as vicissitudes de suas respectivas áreas de atuação. A existência da rede de bancos estaduais públicos pode ser considerada ainda como uma estratégia de manutenção do comando das finanças mais regionalizado, menos centralizado.

Por fim, vale destacar que parte das ações das autoridades monetárias ensejou um uso financeiro do território menos organizacional, ou ao menos um pouco mais voltado para o controle estatal, público, do comando das finanças. É o caso da manutenção - até o ano de 1988 - da necessidade de "cartas-patente" para a abertura de agências bancárias no país; essa norma do Banco Central permitiu o estabelecimento de uma topologia bancária um pouco mais desconcentrada, até o final da década de 1980. Outra regulamentação do Banco Central que permitiu um controle mais endógeno das finanças é a proibição da compra - por parte de instituições estrangeiras - de bancos de varejo no País. Assim, foi permitido [até o ano de 1994) que os atores financeiros nacionais tivessem o comando sobre os fluxos de crédito e estoques de depósitos bancários realizados em território brasileiro. 
A finança, conforme frisamos no início desta conclusão parcial, ganha mais independência em relação aos demais conteúdos do território. Seu poder de tornar o território "instável" só não é maior pois, no período, o controle dos recursos financeiros é ainda prerrogativa básica de sistemas de ações eminentemente nacionais. "O que há nessa fase", podemos asseverar junto de Milton Santos (1999:9), "são dinheiros nacionais internacionalizados". 


\section{PARTE 3 - A VERTICALIZAÇÃO DO SISTEMA BANCÁRIO NACIONAL: PRIVATIZAÇÕES E HIPERCAPILARIDADE DO CRÉDITO \\ (1994-2006)}




\section{Introdução}

A partir do final da década de 1980 o mundo conhece uma série de mudanças, tanto no que diz respeito às possibilidades técnicas à disposição dos Estados e das empresas, como também em relação aos conteúdos normativos que passam a regular as relações entre os países.

No que tange às novas possibilidades técnicas do período, o fenômeno que traz especificidade ao novo tempo é a banalização mais acelerada das "técnicas da informação" (SANTOS, 1996: 146 e ss.). Mas o que é importante destacar em sua relação com os territórios, é que as técnicas da informação permitem uma unificação do controle das demais técnicas preexistentes (técnicas industriais, agrícolas, dos serviços mais diversos) que gera, por seu turno, a possibilidade de manipulação dos tempos produtivos dos territórios nos quais ela se instala. Daí podermos falar que as técnicas da informação permitem uma "unicidade técnica" do mundo contemporâneo, assim como uma "unicidade do tempo"(SANTOS, 1996:146-162). Os tempos regionais são cada vez menos comandados localmente; a instantaneidade do deslocamento das finanças, direta ou indiretamente, acabam por atingir todos os pontos do território.

Essa "unicidade técnica", por sua vez, permitiu que a interdependência das regiões produtivas aumentasse ainda mais. Principalmente as grandes empresas multinacionais (sejam elas do ramo automobilístico, de alimentos, siderurgia, telecomunicações etc.) possuem hoje uma topologia que perpassa e une vários países em seus circuitos produtivos. Para estas empresas hegemônicas é que o território se torna mais "fluido" (SANTOS e SILVEIRA, 2001; ARROYO, 2003; 2005), isto é, sua base técnica se adequa para tornar as ações hegemônicas ainda mais eficientes. Essa interdependência, porém, vem acompanhada de uma nova hierarquização, tanto das empresas quanto das regiões produtivas; a unicidade técnica autoriza alguns países selecionados, assim como algumas empresas mais 
dinâmicas, a comandarem os ritmos locais dos demais países, em uma economia que é cada vez mais globalizada.

No que diz respeito às novas formas de regulação deste mundo unificado, neste período é também consolidada a ação de organismos de caráter global que procuram ditar normas e regras (comerciais, diplomáticas, culturais) que influenciam - em maior ou menor grau - todos os países do mundo. O fato é que as nações do centro do sistema capitalista, que detêm o comando destes organismos de caráter global (como a Organização Mundial do Comércio - OMC, Fundo Monetário Internacional, Banco Mundial, entre outros), desde meados da década de 1980 procuram induzir um processo de liberalização normativa entre os países. Na busca de tirar o máximo proveito comercial e político da unicidade técnica instalada, nações ricas e grandes empresas transnacionais trabalham para que haja cada vez menos impedimentos normativos para que seus fluxos de capitais, bens e mercadorias circulem pelo mundo.

É justamente essa nova realidade técnica "informacional", conjugada com a unificação normativa dos países, que faz aumentar ainda mais a importância das instituições financeiras no mundo atual. Para Ron Martin (1999:17), "inovação tecnológica", "desregulação" e "globalização" são os três fatores que comandam "o remapeamento contemporâneo da paisagem financeira". Já Barney Warf [1999:227-239] sugere que estaríamos vivendo num era de "colapso do keynesianismo", e que o capital financeiro adquire uma "hipermobilidade" nunca dantes vista. Esta nova realidade, neste sentido, parece ser uma chancela do atual período histórico para o vaticínio de Vladimir Lênin (1917, 1986:625): “O capital financeiro estende assim as suas redes, no sentido literal da palavra, em todos os países do mundo".

O fato é que as novas técnicas da informação alteraram o alcance e as velocidades de deslocamento de fluxos financeiros, com repercussões bastante sensíveis para a organização do espaço geográfico. E em grande parte, são os próprios bancos os 
principais atores que financiam novas técnicas da informação, já que a otimização destas permite aumentar sobremaneira o alcance e a eficiência de suas ações. São os bancos também que criam formas novas de moeda - as chamadas "moedas informacionais" (GOLDFINGER, 1987) - que facilitam bastante a inserção de suas atividades tanto em "áreas opacas" quanto em "áreas luminosas" (SANTOS, 1993; SILVEIRA, 1999) do planeta.

É sobre este cenário que se desenvolve o processo de globalização atual, cuja influência no território brasileiro (assim como nos demais países da periferia do capitalismo) foi bastante pronunciada nos últimos anos. A alteração dos conteúdos normativos do território, dos ritmos de seus fluxos, assim como da topologia de suas instituições financeiras são alguns dos rebatimentos no território nacional deste mundo globalizado. 


\section{CAPÍTULO 8. Tecnoesfera e Psicosfera: Objetos Informacionais e Ideologia da Privatização}

\subsection{Os novos conteúdos informacionais: bases para uma geografia corporativa}

A configuração territorial brasileira na década de 1990 tem já parcela considerável de sua extensão composta por um meio técnico-científico informacional bastante desenvolvido. Este tipo novo de meio geográfico ocorre principalmente na Região Concentrada do território, como vimos, mas também em seu litoral, e nos belts e fronts agrícolas modernos do interior do País (SANTOS e SILVEIRA, 2001). Estes novos conteúdos, ricos em técnica e informação, perenizaram-se em grande parte em função do esforço realizado pelos sucessivos planos de integração material e imaterial do território, como vimos no capítulo 5.

Um exemplo desse avanço atual na incorporação da variável "informação" ao território é dado pelos "serviços telemáticos" (CASTILLO, 1999) que passam a ser oferecidos por empresas de telecomunicações, ampliando as possibilidades de circulação de mensagens, imagens, dados, por praticamente toda a extensão do territorial nacional. Também a "agricultura cientifizada", que tem na informação um de seus insumos principais, é que permitiu a incorporação de várias regiões pouco habitadas, numa divisão territorial do trabalho em moldes capitalistas contemporâneos (SANTOS e SILVEIRA, 2001:118 e ss.).

De maneira esquematizada, podemos dizer que os dois principais componentes desta base técnica atual são as "redes de informação" (DIAS, 1996) e os chamados "sistemas técnicos orbitais" (CASTILLO, 1999). A conjugação destes dois novos componentes do espaço nacional é que permite uma eficiência maior de parte significativa das ações de grandes empresas no território. 
Estes novos sistemas de engenharia que aumentam a quantidade e a velocidade dos fluxos infomacionais no país a partir da década de 1990 aprofundam alguns processos iniciados na década de 1970. Leila Dias (1996:127) nos lembra que a rede TRANSDATA, por exemplo, aumentou a velocidade de transmissão de dados que era de 9.600 bits/segundo naquele período, para 48 kilobits/segundo, no ano de 1990. O geógrafo Rubens Toledo Jr. (2002) nos chama a atenção para a difusão das redes de fibra ótica, principalmente na Região Concentrada do território brasileiro. As infra-estruturas instaladas recentemente ligaram principalmente as cidades de São Paulo/Rio de Janeiro/BeloHorizonte, aumentando a densidade informacional desta região que já era uma das mais dinâmicas em termos de sua dotação de sistemas de engenharia modernos ${ }^{91}$.

Duas das principais empresas atuantes na extensão das redes de fibra ótica no Brasil são:

1) Embratel: responsável pela instalação da rede em bases nacionais (une de São Luiz até Porto Alegre), e que possuía em 2002 cerca de 24 mil quilômetros espalhados, em redes interurbanas de comunicação deste tipo;

2) Eletronet: atualmente com cerca de 16.000 quilômetros de fibras óticas instaladas, responde também pela interligação de importantes cidades da Região Concentrada, com municípios das Regiões Nordeste e Centro-Oeste do país.

As ações destas empresas são dois exemplos de como novas redes-suporte foram incorporadas ao espaço brasileiro, permitindo que outras formas geográficas e organizacionais se instalassem.

Também no que diz respeito às redes de telefonia, os avanços quantitativos são de grande monta na década de 1990. Segundo dados da Anatel (Agência Nacional de Telecomunicações), a telefonia fixa passa de 10,3 milhões de aparelhos instalados

${ }^{91}$ O desenvolvimento expressivo da rede de fibras óticas nesta região levou a mesma a ser conhecida também como "Triângulo de Cristal", em referência ao vidro, um dos principais insumos utilizado na confecção das fibras (TOLEDO Jr., 2002). 
no ano de 1990 para nada menos que 38,3 milhões no ano de 2000; em 2004, o número de telefones no território é de 42,3 milhões. Outra novidade digna de nota passa a compor a realidade de nossa rede de telecomunicações no mesmo período: a telefonia celular. De 755.200 linhas existentes no ano de 1994, o Brasil passa a contar com nada menos que 23,2 milhões no ano de 2000 . Um crescimento, portanto, ainda impressionante: num período de apenas seis anos, o número de telefones celulares aumenta em 2.972\% (ANATEL, 2001:18). Ao final de 2006, a quantidade de aparelhos em uso é ainda mais surpreendente: são nada menos que 99.918.621 telefones deste tipo fazendo parte do moderno sistema de telecomunicações do território (ANATEL, 2006).

Além desses sistemas técnicos mais banalizados, dos quais boa parte da população brasileira faz uso, cresceram também no período alguns circuitos que possibilitaram uma melhor performance para as empresas instaladas no território: as chamadas "redes corporativas" (DIAS, 1995; CASTILLO, 1999). Estas redes englobam aqueles conjuntos de linhas e pontos de geração de informação que são utilizados com exclusividade por empresas mais modernas, nacionais ou globais. Elas podem também ser consideradas como "redes hegemônicas" (SILVEIRA, 1996), já que se prestarão ao uso por uma parcela muito pequena e elitizada das corporações privadas atuantes no território brasileiro.

Conforme buscamos mostrar no capítulo 5, a partir do início da década de 1980 a Empresa Brasileira de Telecomunicações (EMBRATEL) disponibiliza o sistema Transdata para ser utilizado pelas grandes firmas, na veiculação de mensagens e informações internas. Também oferece, no mesmo período, a Rede Nacional de Comunicação de Dados por Comutação de Pacotes (RENPAC), esta baseada na infra-estrutura telefônica já instalada (DIAS, 1995; 1996). Pareceu-nos importante destacar estas duas modalidades de "serviços telemáticos" que são incorporados no espaço nacional, pois eles permitem novas formas de uso do território pelas grandes empresas, em particular pelos bancos aqui instalados. Como nos lembra também Castillo (1999:186), 
"Percebemos que o RENPAC e o TRANSDATA são sistemas que, além de formar uma vasta rede de comunicação de dados do território, ainda permitem a conexão destas redes com redes similares de abrangência mundial. Possibilitaram a construção das primeiras redes eficientes de comunicação de dados no território brasileiro, permitindo a expansão territorial das empresas, sobretudo bancos, e contribuindo largamente para o aumento exponencial de fluxos informacionais lordens, comandos, controle, acesso a banco de dados etc.) entre as principais cidades de um país de dimensões continentais, inaugurando os serviços telemáticos no Brasil".

Através da descrição de alguns dos sistemas técnicos informacionais que passam a ser parte constitutiva do espaço nacional, podemos entender um pouco melhor como se torna possível uma maior centralização das atividades econômicas desenvolvidas no território, assim como são aumentadas as formas de ligação da economia nacional com a economia mundial. Como lembra Barney Warf (2006:1), tanto as tecnologias dos satélites, quanto as das fibras óticas aumentaram o poder das grandes empresas globais, assim como catalisaram o processo de “desregulação" pela qual passam as economias nacionais, desde meados dos anos 1980.

\subsection{A capilarização de novos sistemas técnicos e o uso agrícola do território}

A modernização das infra-estruturas ocorre também no campo brasileiro. Há um dinamismo bastante pronunciado das culturas voltadas para a exportação, como é o caso da soja, nos estados do Paraná, Mato Grosso, Mato Grosso do Sul, nas regiões Sul e Centro-Oeste do País (FERNANDES et alli, 1988; BERNARDES, 1996). Mas o dinamismo da oleaginosa atinge também áreas de ocupação mais recente, principalmente no sul dos estados do Piauí e Maranhão, além do oeste da Bahia.

Nos estados do Sul do País, com uma agricultura de base mais diversificada, continuam sendo cultivados produtos para a exportação, mas também o trigo, arroz, milho, entre outros destinados principalmente ao mercado consumidor nacional (BRUM, 1988). O fato é que tanto as regiões agrícolas tradicionais, quanto aquelas que passam a ser incorporadas através da expansão do meio técnico-científico informacional, são também resultado da divisão territorial do trabalho que se instala. As necessidades de consumo alimentar dos grandes centros 
urbanos, e a própria inserção do país na rede de comércio global de commodities agrícolas, faz aumentar as racionalidades técnicas e capitalistas no campo.

Esforços recentes têm sido feitos para capilarizar nas áreas agrícolas do país novos sistemas técnicos, na busca de aumentar a produtividade espacial dos lugares para os cultivos interessantes ao mercado nacional e internacional. Manifestações concretas dessa capilarização do meio técnico no campo (que fora iniciado ainda nas décadas de 1960 e 1970) são aquelas logradas com as políticas públicas de eletrificação das áreas agrícolas do País. Com a difusão da eletricidade nas áreas produtivas, toda uma nova família de técnicas é também passível de ser utilizada com mais regularidade no meio agrícola (iluminação doméstica, aparelhos de bombeamento, sistemas de irrigação, eletrodomésticos etc.).

Mas não só a eletrificação rural é um fenômeno que se incrementa na atualidade. Também a difusão de fixos geográficos como escolas, estradas, postos de saúde, continuam esse processo de transformação do espaço brasileiro, numa base mais tecnicizada.

Tabela 17: Brasil: Criação de Infra-estruturas em Áreas Agrícolas pelo Governo Federal (1995-1998)

\begin{tabular}{|l|r|r|r|r|}
\hline & \multicolumn{2}{|c|}{$\mathbf{1 9 9 5}$} & \multicolumn{2}{c|}{$\mathbf{1 9 9 8}$} \\
\hline & Quantidade & \multicolumn{1}{|c|}{ Valor (R\$) } & Quantidade & \multicolumn{1}{c|}{ Valor (R\$) } \\
\hline Açudes & 33 & 2.733 .632 & 598 & 6.969 .402 \\
\hline Armazéns & 8 & 272.318 & 56 & 2.486 .029 \\
\hline Centros Comunitários & 22 & 668.935 & 201 & 5.770 .232 \\
\hline $\begin{array}{l}\text { Eletrificação Rural (em } \\
\text { km) }\end{array}$ & 663 & 3.375 .689 & 5.546 & 9.180 .543 \\
\hline Escolas & 71 & 6.162 .908 & 136 & 2.460 .231 \\
\hline Estradas (em km) & 1812 & 14.676 .361 & 13.824 & 106.251 .022 \\
\hline Postos de Saúde & 5 & 349.889 & 250 & 4.374 .376 \\
\hline Poços & 44 & 1.085 .001 & 743 & 15.896 .032 \\
\hline TOTAL & & 29.415 .733 & & 183.387 .858 \\
\hline
\end{tabular}

Fonte: Incra, Anos Selecionados; adaptado de MALIN (2002:188-189)

Prossegue um movimento que - como nas cidades - requer as finanças para a realização dos investimentos em novas infra-estruturas (estradas, eletricidade, 
escolas), e que inserem gradativamente novas possibilidades organizacionais também no espaço agrícola do país.

\subsection{O consumo e a nova geografia urbana brasileira}

A partir da década de 1990 a população do país torna-se ainda mais urbanizada, como mostram os dados do Instituto Brasileiro de Geografia e Estatística (IBGE, 2006). Se em 1991 o índice de urbanização da população era de 75,9\% (dos 146 milhões de habitantes, perto de 110 milhões habitavam as cidades), esse índice passa para $81,5 \%$ no ano de 2000 (dos 169 milhões de brasileiros, 137 milhões eram urbanos].

Além do aumento da quantidade de pessoas morando em cidades, também a natureza da vida urbana parece ganhar outro significado no período técnicocientífico informacional. A carência recorrente de recursos para o financiamento de políticas sociais, assim como a falta generalizada de infra-estruturas públicas urbanas (para o provimento de serviços como a saúde, educação, acesso a bens culturais) torna a vida de parte da população bastante difícil. No limite, como sugeriu Milton Santos $(1987,1996)$, não se pode dizer que o Brasil é formado por um país de cidadãos de fato. Mais correto seria falar na existência de "nãocidadãos" aqui vivendo ${ }^{92}$.

Um das principais características desta "não-cidadania” é justamente a importância que adquire o fenômeno do consumo ${ }^{93}$ nas cidades brasileiras, no período atual. $\bigcirc$

\footnotetext{
92 Para o autor, "em nenhum outro país foram assim contemporâneos e concomitantes processos como a desruralização, as migrações brutais desenraizadoras, a urbanização galopante e concentradora, a expansão do consumo de massa, o crescimento econômico delirante, a concentração da mídia escrita, falada e televisionada, a degradação das escolas, a instalação de um regime repressivo com a supressão dos direitos elementares dos indivíduos, a substituição rápida e brutal, o triunfo, ainda que superficial, de uma filosofia de vida que privilegia os meios materiais e se despreocupa com os aspectos finalistas da existência e entroniza o egoísmo como lei superior, porque é o instrumento da busca da ascensão social"(SANTOS, 1987, 1996:12/13).

93 Certamente o primeiro geógrafo que tratou de maneira sistemática a questão do consumo foi Jean Gottmann (1947) em seu texto "Do Método de Análise em Geografia". Para o autor, "o consumo não é somente importante como efeito; ele é ainda essencial (capitale) como causa. Não é ele, segundo a lei da oferta e da procura, o regulador final da produção e dos transportes?"(GOTTMANN, 1947:10). E chama ainda a atenção para a importância do "fator psicológico", que faz com que o "homem civilizado" tenha também necessidades de consumo não-essenciais, ou "caprichos"; "as necessidades de consumo são crescentes no curso dos séculos, necessidades de objetos cada vez mais complicados e cada vez mais frágeis, que têm cada vez mais lugar em nossa noção de civilização"(op. cit., 1947:11). Ver também Pierre George (1971).
} 
fenômeno do consumo nas cidades é mais intenso - desde sempre - pois nelas os habitantes são obrigados a vender sua força de trabalho, para adquirir (consumir) seus meios de subsistência. A renda do trabalho, portanto, é a base para o consumo urbano. Mas no período atual, as populações urbanas estão mais expostas a vetores que potencializam as práticas de consumo. Um destes vetores é a própria financeirização da vida cotidiana, dada pela maior acessibilidade das pessoas ao fenômeno do crédito (como veremos nos capítulos 10, 11 e 12); o outro vetor é a publicidade, que leva cada vez mais o consumo conspícuo ${ }^{94}$ a tomar o lugar do consumo verdadeiramente necessário para a reprodução da vida. Por que aumenta o peso deste consumo conspícuo?

Já que a população do país passa a ser eminentemente urbana (desde ao menos a década de 1970), vale dizer que ela é também, cada vez mais, sensível ao que George Simmel $(1902,1976)$ chamou de "intensificação dos estímulos nervosos" provocada pela vida em grandes cidades. Isto é, os citadinos são mais expostos (pela proximidade física e organizacional) aos novos vetores da modernidade que se dão, par excellence, nos meios urbanos de todo o globo terrestre. $\mathrm{O}$ acesso diuturno a novas formas de comunicação (por televisão, rádio, internet, telefones celulares etc.) faz chegar às cidades pequenas e médias, mas principalmente nas metrópoles nacionais, uma quantidade inaudita de informações, mensagens e estímulos eletrônicos de toda sorte.

Estas informações, por seu turno, estão em boa parte ligadas ao fenômeno da publicidade, que "tem por tarefa divulgar as características deste ou daquele produto e promover-lhe a venda" (BAUDRILLARD, 1968, 1993:174). Com a publicidade, portanto, "os objetos se apresentam antes de terem sido adquiridos, antecipam-se à soma de esforços e do trabalho que representam, seu consumo por assim dizer precede sua produção"(BAUDRILLARD, 1968, 1993:168). São

94 "Consumo conspícuo" foi o conceito utilizado pelo economista norte-americano Thorstein Veblen [1899, 1983) para designar aquele consumo voltado eminentemente para a manutenção do status ou da posição social do indivíduo consumidor; diz respeito muito mais ao "hábito da ostentação", ou ainda ao "dispêndio com coisas supérfluas" do que à determinada(s) utilidade(s) efetiva do produto consumido para o indivíduo. Para uma crítica mais atualizada sobre o consumo no mundo contemporâneo, ver ainda Albert Hirschman [1983). 
diversificadas e aumentadas as necessidades de consumo da população das grandes cidades (SANTOS, 1994c; ANTONGIOVANNI, 2001). São também Milton Santos e María Laura Silveira (2001: 224) que lembram que recentemente ocorre forte "expansão das diferentes formas de mídia e da indústria cultural", sendo que a "publicidade" e a "produção da propaganda" se tornam vetores cada vez mais influentes da vida urbana.

Mas como se geografizam estas formas do período histórico, que dão peso significativo ao consumo? Quais elementos do espaço que passam a fazer parte da paisagem urbana atual, e que indicam este poder organizador do consumo e da publicidade no mundo contemporâneo?

Talvez um bom exemplo deste poder organizador do consumo seja dado pela instalação dos chamados Hipermercados, nas cidades grandes e médias do país. Assim como a difusão dos Shopping Centers, essa forma geográfica parece instalar uma nova "geografia do marketing" (BERRY, 1967, 1971) 95 nas cidades brasileiras, que aumenta significativamente as possibilidades de consumo dos habitantes das grandes cidades. O exemplo da evolução da distribuição dos Hipermercados Extra no Estado de São Paulo é bastante indicativo destes fenômenos.

O que parece ser interessante destacar é a concentração dos Hipermercados na Região Metropolitana de São Paulo: dos 39 existentes até o ano de 2003 - data da publicação do texto de Carlos H. da Silva (2003) - nada menos que 30 Hipermercados estavam naquela região (isto é, $77 \%$ dos totais). Somados aos Shopping Centers, cinemas de grandes cadeias internacionais, agências bancárias para clientes de alta renda, os Hipermercados pareceram ser uma manifestação geográfica bastante concreta destas novas "necessidades" de consumo que as cidades brasileiras despertam em seus habitantes.

95 A "Geografia do Marketing" de Brian Berry teria como meta "avaliar o funcionamento de um estabelecimento ou centro comercial, estudar as transformações produzidas por novos competidores (em todos os debates sobre centros comerciais está implícita uma hierarquia de três níveis: vicinal, local e regional), ou estimar as vantagens dos estabelecimentos (asentamientos) e os potenciais benefícios derivados de novas localizações (emplazamientos) de comércios ou centros"(BERRY, 1971:168-169). 
Tabela 18: Estado de São Paulo: Ano de Inauguração dos Hipermercados Extra

\begin{tabular}{|l|r|l|r|l|r|}
\hline \multicolumn{2}{|c|}{ Cidade de São Paulo } & \multicolumn{2}{c|}{ Grande São Paulo } & \multicolumn{2}{c|}{ Interior do Estado } \\
\hline Loja & Ano & Loja & \multicolumn{1}{c|}{ Ano } & Loja & \multicolumn{1}{c|}{ Ano } \\
\hline Aeroporto & 1990 & São Bernardo & 1997 & Campinas (Abol.) & 1990 \\
\hline Brigadeiro & 1990 & São Caetano & 1997 & $\begin{array}{l}\text { Campinas } \\
\text { (Amor.) }\end{array}$ & 1996 \\
\hline Anhanguera & 1993 & Carapicuíba & 1998 & Itatiba & 1998 \\
\hline Guarapiranga & 1994 & Diadema & 1998 & São Carlos & 1998 \\
\hline SP Market & 1995 & Int. Guarulhos & 1998 & Santos & 1999 \\
\hline Aricanduva & 1996 & Guarulhos & 1998 & Praia Grande & 1999 \\
\hline João Dias & 1998 & Santo André & 1999 & Araraquara & 2000 \\
\hline Cidade Dutra & 1998 & Cotia & 1999 & Sorocaba & 2000 \\
\hline Interlagos & 1998 & Brás Cubas & 1999 & Itu & 2001 \\
\hline Penha & 1998 & Mogilar & 1999 & - & - \\
\hline Morumbi & 1999 & Taboão da Serra & 2001 & - & - \\
\hline Tietê & 1999 & Mauá & 2002 & - & - \\
\hline Praça Ramos & 1999 & - & - & - \\
\hline Itaim & 2000 & - & - & - \\
\hline Guianazes & 2001 & - & - & - & - \\
\hline Freguesia do Ó & 2002 & - & - & - & - \\
\hline Raposo & 2002 & - & - & - & - \\
\hline Jaguaré & 2002 & - & - & - \\
\hline Fonte: Assoça & - & - & - \\
\hline
\end{tabular}

Fonte: Associação Brasileira de Supermercados (ABRAS); adaptado de SILVA (2003:387)

A nova materialidade do território, portanto, é bem mais intensa em técnica e em informação. Tanto no que diz respeito às novas redes corporativas, ao espaço agrícola modernizado, assim como à dinâmica atual das grandes cidades, podemos dizer que uma tecnosesfera (SANTOS, 1994; 1996) se instala no território. Esta tecnosfera, por seu turno, vai estimular um novo conjunto de crenças, de formas de entendimento, de hábitos que compõem a psicosfera do espaço nacional (SANTOS, 1994; 1996). Isto é, ao passo que as infra-estruturas e os novos conteúdos materiais se transformaram, também foram alteradas as formas de 
pensar, assim como as ideologias e - destarte - as maneiras possíveis de organizar as formas geográficas contemporâneas ${ }^{96}$.

\subsection{A nova psicosfera: a ideologia das privatizações e da liberalização normativa}

O grande poder que adquirem as corporações no mundo contemporâneo permite que parte delas comande importantes dados da organização dos territórios e das sociedades. Uma das formas de organizar as sociedades e os territórios, como mencionamos há pouco, é através da difusão de uma ideologia da publicidade e do consumo, que estão na base do predomínio das "forças de mercado" sobre o processo de reprodução social e econômica. Em função deste aumento do poder das lógicas de mercado na condução dos processos sociais, Ladislau Dowbor (1998) afirma que vivemos numa época de predomínio de uma "reprodução capitalista", em detrimento de uma "reprodução social" da vida.

Ao contrário do que ocorrera a partir das décadas de 1960 e 1970, há um movimento de transferência do controle das atividades econômicas, políticas, culturais para a esfera da iniciativa privada. Numa palavra, podemos dizer que passamos de uma "política dos Estados" para uma "política das empresas" (SANTOS, 2000), na organização de praticamente todos os domínios da vida humana em sociedade, inclusive o espaço geográfico. Assistimos a um processo de privatização do controle destes domínios, se pensarmos no senso lato da

\footnotetext{
96 Segundo Milton Santos, no atual período histórico, "ao mesmo tempo em que se instala uma tecnosfera dependente da ciência e da tecnologia, cria-se, paralelamente, e com as mesmas bases, uma psicosfera. A tecnosfera se adapta aos mandamentos da produção e do intercâmbio e, desse modo, freqüentemente traduz interesses distantes; desde, porém, que se instala, substituindo o meio natural ou o meio técnico que a precedeu, constitui um dado local, aderindo ao lugar como uma prótese. A psicosfera, reino das idéias, crenças, paixões e lugar da produção de um sentido, também faz parte desse meio ambiente, desse entorno da vida, fornecendo regras à racionalidade ou estimulando o imaginário" (SANTOS, 1996:204). A busca de um entendimento de como o mundo das idéias e das crenças altera a concepção e os usos do espaço geográfico é bastante antiga na disciplina. Para a geografia existencialista de Eric Dardel (1952:50), por exemplo, “a realidade geográfica age sobre o homem por um despertar (éveil) da consciência. Por vezes ela opera como um sonho, como se antes mesmo que nós tenhamos consciência, ela já está aqui". A socióloga Ana Clara Torres Ribeiro, por seu turno, ao se debruçar também sobre a psicosfera do território brasileiro ao final da década de 1980, lembra que esta "produz a busca social da técnica e a adequação comportamental à interação moderna entre tecnologia e valores sociais. Alguns setores produtivos parecem alimentar, com especial ênfase, os processos culturais de consolidação dessa psicosfera, conformando verdadeiros pólos emissores de valores"(RIBEIRO, 1991:48).
} 
expressão97. A dimensão "nacional" do desenvolvimento econômico deixa também, paulatinamente, de ser um dado importante das políticas de planejamento nos países que almejam uma melhora de suas infra-estruturas ${ }^{98}$.

Podemos dizer que até meados da década de 1970, há “uma fase heróica de constituição e projetamento de empresas sob controle do Estado"(PALATNIK e ORENSTEIN, 1979:49); no caso do Brasil, essa atuação foi fundamental para a criação de grandes infra-estruturas (de telecomunicações, energia e transportes) e para o suprimento de insumos básicos para as empresas privadas de produção de bens de consumo duráveis (carros, eletrodomésticos) semi-duráveis (roupas, calçados) e não-duráveis (alimentos) - como vimos no capítulo cinco ${ }^{99}$.

Este estado de coisas começa a ser alterado no final da década de 1970, e partem principalmente da Inglaterra e dos Estados Unidos as novas ideologias liberais, que preconizavam uma diminuição (quando não uma ausência total) da ação estatal na organização da economia e dos territórios ${ }^{100}$. Essas ideologias repercutem, ao

\footnotetext{
97 Como asseveram Sun Sheng Han e Clifton Pannell "no sentido mais geral, privatização é o processo de mudança estrutural que envolve não-nacionalização (non-nationalization), liberalização ou relaxamento das regulações, e utilização das capacidades do setor privado para o provimento de serviços"'(1999:272). Se fizermos um pequeno recuo histórico, verificaremos que ao final da Segunda Guerra Mundial era bastante aceito (tanto nos meios intelectuais, como entre as elites políticas dos países) o fato de que a intervenção estatal era necessária para o desenvolvimento econômico e social das nações. Do ponto de vista da teoria econômica que balizava este entendimento, podemos dizer que o "Keynesianismo" é que autorizava políticas com maior ação do estado: era necessário "salvar o capitalismo de seus próprios males, através do gerenciamento da demanda pelo governo"(ANDERSON, 1991:14).

98 Praticamente toda a literatura produzida no âmbito do Instituto Superior de Estudos Brasleiros (ISEB) - nas décadas de 1950 e 1960 - é bastante representativa deste entendimento em bases mais "nacionais" do desenvolvimento econômico. Como escrevera um dos principais representantes do ISEB à época, o "ponto capital", e "imprescindível" era a "ideologia do desenvolvimento nacional"(PINTO, 1960:30), para alcançar o "processo histórico de crescimento nacional"(op. cit:36). Ver ainda Hélio Jaguaribe (1958) e Alberto Guerreiro Ramos $(1958,1996)$. O modelo de desenvolvimento chinês atual parece ser um exemplo de como a formação socioespacial (isto é, a dimensão nacional dos países) se mantém ainda como elemento essencial na construção de políticas de longo prazo (JABBOUR, 2006).

${ }^{99}$ Empresas como a Companhia Siderúrgica Nacional (CSN), Rede Ferroviária Federal (RFFSA) e a EMBRATEL (junto com a Petrobrás, os Correios, as demais siderúrgicas estatais) eram consideradas "empresas de desestatização praticamente impossível"(PALATNIK e ORENSTEIN, 1979:58), por dois principais motivos: a) do ponto de vista do conteúdo normativo do território, essas empresas eram "monopólio legal do Estado"; e b) do ponto de vista dos balanços, eram empresas cuja "situação financeira (era) absolutamente desinteressante para o capital privado"(op. cit, 1979:60). A estes dois motivos, podemos acrescentar também que havia uma psicosfera (que balizava as ações da elite política como as da elite econômica do país) que via no processo de privatização um entrave em relação ao "projeto nacional” que se almejava na época.

${ }^{100}$ A expansão da ideologia liberal na Europa teve também a conseqüência positiva de influenciar a descolonização dos países do Terceiro Mundo ainda sob tutela política e econômica de países europeus. É o caso, sobremaneira, da descolonização da África portuguesa. Como mostra Lincoln Secco (2004:192), já nas décadas de 1960 e 1970 “a Europa Liberal desautorizava os impérios", e a "descolonização também se impunha", em parte como resultado da vontade de adesão de Portugal aos princípios que balizavam a concretização da Comunidade Européia.
} 
longo de toda a década de 1980, na psicosfera brasileira. A evolução desta repercussão acaba por tornar hegemônicos novos conjuntos de crenças - ou ideologias - que podemos esquematicamente dividir em dois tipos: a ideologia da privatização e a da liberalização normativa ${ }^{101}$.

Se no início da década de 1980 a ideologia da privatização emerge timidamente no Brasil, ela ganha bastante fôlego com a eleição de Fernando Collor de Mello para a Presidência da República, no ano de 1989 (SCHNEIDER, 1992; PINHEIRO e GIAMBIAGGI, 1992). A partir de então, a crença na privatização passa a pautar as principais diretrizes da elite política nacional em relação à organização do território. Neste sentido, por se constituir num "discurso diretamente normativo a respeito do espaço" (MORAES, 1988:45), a privatização pode ser considerada também como uma "ideologia geográfica", interferindo diretamente nos destinos da nação.

Vale ressaltar que além do processo de privatização, ocorre também uma forte desnacionalização de empresas estratégicas brasileiras (GONÇALVES, 1999), o que aumenta ainda mais a (inter)dependência dos sistemas de engenharia do território em relação aos movimentos da economia global. Em função da consecução destas mudanças, parece mais correto falarmos atualmente em "espaços nacionais da economia internacional", do que de "economias nacionais", como advoga Michel Beaud (1987) ${ }^{102}$. O fenômeno do "alargamento dos contextos" (SANTOS, 1996) se instala no território, e as ações que aqui se funcionalizam são cada vez mais globais; o motor das ações é externo, portanto.

\footnotetext{
101 O tema da ideologia gerou uma vasta bibliografia, principalmente de matriz marxista. Uma visão importante do conceito é dada por Louis Althusser, para quem “a ideologia é uma 'representação' da relação imaginária dos indivíduos com suas condições reais de existência” (ALTHUSSER, 1974, 2001:85). O trabalho de Antonio Carlos Robert de Moraes (1988) nos dá uma rica operacionalização do conceito - baseado numa matriz gramsciana - para a análise do território brasileiro.

${ }^{102}$ Vele notar que também Michel Beaud dá uma importância central às novas técnicas do período como importantes fatores da transformação das economias nacionais. Para ele, "Com as novas tecnologias, o progresso dos meios de telecomunicação e de tratamento de informações, as dimensões internacionais/multinacionais e mundiais vão se reforçar, com impactos crescentes nos domínios informacional, cultural, intelectual, monetário e financeiro"(BEAUD, 1987:126).
} 
Pensando ainda no caso brasileiro, Adriana Bernardes (2001:218) nos lembra que, ironicamente, o programa do Governo Federal instalado no ano de 1991 para acelerar o processo de privatizações no País foi intitulado Programa Nacional de Desestatização, ou PND. Mas, ao contrário da sigla "homônima" que - como vimos - dava nome aos dois principais programas de reconstrução da base técnica nacional na década de 1970 (o Plano Nacional de Desenvolvimento I e II), o Programa de Desestatização levou a uma privatização de proporções vultosas dos sistemas de engenharia nacionais. Desde a criação do programa, até o ano de 2000, foram privatizadas 130 estatais, sendo 92 delas federais e 38 estaduais (PINHEIRO, 2000:22).

Os principais setores afetados foram justamente aqueles construídos com o endividamento do Estado nacional nas décadas de 1970 e 1980: siderurgia, telecomunicações, química/petroquímica e energia elétrica. Segundo estudo de Armando Pinheiro (2000:22), foram movimentados neste período um total de US\$ 100,1 bilhões, resultado tanto de receitas de venda das estatais, como de transferência de dívidas no processo de aquisição. As principais empresas e sistemas de engenharia privatizados no âmbito do referido Programa foram:

1) Siderurgia: Usiminas, Cosinor, Aços Finos Piratini, CST, Acesita, CSN, Cosipa, Açominas;

2) Química e Petroquímica: Petroflex, Copesul, Nitriflex, Polisul, PPH, CBE, Poliolefinas, Deten, Oxiteno, PQU, Copene, Salgema, CPC, Polipropileno, Álcalis, Pronor, Politeno, Nitrocarbono, Coperbo, Ciquine, Polialden, Acrinor, Koppol, CQR, CBP, Polibrasil, EDN;

3) Empresas de fertilizantes: Arafértil, Ultrafértil, Goiasfértil, Fosfértil, Indag; 4) Sistema de geração de eletricidade: Light, Escelsa, Gerasul (federais); Celpe, Enersul, Coelce, CEG, CPFL, Cemat, Energipe, Celpa, Eletropaulo Metropolitana, Coelba, Cesp-Paranapanema, Cesp - Tietê (estaduais);

5) Sistema de movimento ferroviário: RFFSA-Malha Oeste, RFFSA-Malha CentroLeste, RFFSA-Malha Sudeste, RFFSA-Teresa Cristina, RFFSA-Malha Sul, RFFSAMalha Nordeste e Malha Paulista (federais); Ferroeste, Flumitrens (estaduais); 
6) Empresas de Mineração: CVRD - Cia. Vale do Rio Doce, Caraíba (BNDES, 2006).

Este quadro indica como a nova psicosfera - no caso ligada à ideologia das privatizações - teve repercussões na organização do território brasileiro, alterando profundamente a estrutura patrimonial dos sistemas de engenharia aqui instalados. O que pode ser dito ainda das conseqüências desta psicosfera em relação à liberalização normativa, que parece ser a outra principal ideologia que pautou a reorganização do território recentemente?

Principalmente através da ação da Organização Mundial do Comércio - que faz de suas normas "armas coercivas" (MICHALAK e GIBB, 1997:267) - são realizados esforços para que esta liberalização normativa se instale no quadro jurídico/constitucional de cada país. Como lembra-nos Milton Santos [1996:182183) tanto a "proliferação" de normas jurídicas, comerciais, de consumos, quanto a "uniformização" delas, são características basilares das novas "exigências do intercâmbio internacional" atual. Essa "produção de unicidades" acaba por reforçar o poder das empresas e dos Estados hegemônicos no mundo contemporâneo.

Parece haver consenso entre alguns autores da bibliografia analisada sobre o tema da liberalização das normas (TAVARES e FIORI, 1996: capítulo 3; GIAMBIAGGI e ALÉM, 1999; VASCONCELOS, STRACHMAN e FUCIDJI, 2003) de que esse fenômeno ganha fôlego maior também nos anos 1990. Como anota Reinaldo Gonçalves, para o caso brasileiro:

\footnotetext{
"A revisão constitucional, principalmente em 1995, veio eliminar as restrições setoriais para a entrada de capital estrangeiro na economia brasileira. Iniciouse, então, o movimento para a flexibilização do monopólio estatal do petróleo. As restrições nos setores da indústria extrativa e de serviços também têm sido gradualmente eliminadas, como, por exemplo, no caso do setor financeiro (...) e de navegação de cabotagem. Nas telecomunicações autorizou-se a participação de empresas estrangeiras no controle das empresas privatizadas" [1999:104).
} 
Quais as principais alterações no arcabouço jurídico brasileiro, que nos permitem afirmar que a liberalização normativa foi importante para essa desnacionalização e privatização dos sistemas de engenharia brasileiros? Giambiaggi e Além [1999:317 e seguintes) elencam ao menos cinco Leis e Decretos, que estariam na base dessa liberalização. Estas normas, ao que nos parece, gradualmente permitiram que a formação socioespacial brasileira pautasse cada vez mais sua evolução por uma "política de empresas", e não mais por uma "política de Estado", conforme os termos de Milton Santos (2000). A evolução recente destes conteúdos normativos, que permitiram uma gradual instalação dos desígnios da nova psicosfera privatista, pode ser resumida com a seguinte cronologia:

1) Decreto no. 86.215 de 15/07/1981, que fixou pela primeira vez regras para a transferência de controle de empresas estatais federais para a iniciativa privada; com essa norma é criada também a Comissão Especial de Desestatização (CED), órgão responsável para coordenar os processos de privatização;

2) Decreto no. 91.991 de 28/11/1985, que cria, no lugar da Comissão Especial de Desestatização (CED), o Conselho Interministerial de Privatização (CIP); a CIP daria suporte técnico e administrativo para a execução das privatizações. Data deste Decreto o Início da ação do BNDES como agente da privatização; ${ }^{103}$

3) Decreto no. 95.886 de 29/03/1988, que instala o Programa Federal de Desestatização (PFD);

4) Medida Provisória No. 155 de 12/04/1990, que cria o Programa Nacional de Desestatização (PND), como mencionamos;

5) Medida Provisória 841 de 19/01/1995, Lei 8.987 de 1995 e Lei 9.074 de 1995; estas três novas normas é que vão permitir, concretamente, a desnacionalização e a privatização das empresas e sistemas de engenharia citados acima; através delas é criado um "novo regime de concessão de

\footnotetext{
${ }^{103}$ Na década de 1990 o BNDES inverte por completo seu papel na organização dos sistemas de engenharia do território brasileiro. Ao invés de realizar investimentos para aumentar a capacidade de controle do empresariado - ou do Estado - brasileiro nos circuitos produtivos nacionais, passa a financiar com recursos públicos parte significativa do processo de desnacionalização destes sistemas. Para o caso da desnacionalização catalisada pelo BNDES ver Bernardes (2001: 218 e ss.); em relação especificamente à ação do Banco para o sistema energético no período, ver Bermann (2003) e Ramalho (2006).
} 
serviços públicos" que, por seu turno, tornou passíveis de serem vendidas empresas estatais de "infra-estrutura e de serviços de utilidade pública"(GIAMBIAGGI e ALÉM, 1999:323).

Estes novos conteúdos normativos do espaço - muito mais permissivos às ações dos vetores externos no território - é que permitem, junto das redes informacionais instaladas, uma ação mais direta de firmas globais no espaço nacional. Neste sentido, podemos nos perguntar: o que teria ocorrido com o sistema financeiro brasileiro, a partir da década de 1990? Quais as principais políticas do governo que influenciaram diretamente a organização espacial dos atores do sistema bancário nacional a partir de então? 


\section{CAPÍTULO 9. A Construção da Racionalidade Globalizada no Território: Plano Real, PROES e PROER}

Dada a fase atual da globalização, em que uma unicidade técnica se faz onipresente no planeta, como entender as parcelas de cada território, sem pensar na totalidade mundial? E como entender a materialidade dos sistemas técnicos, das infra-estruturas, sem levar em conta a posição relativa que ocupam neste mundo unificado?

Conforme destacado na introdução da tese, podemos entender as formas geográficas não só a partir de sua materialidade, mas também a partir dos conteúdos sociais, econômicos e normativos que incidem atualmente sobre essas formas. Esta é, de maneira bastante resumida, a proposta de se entender os elementos do espaço geográfico como "formas-conteúdo", e não apenas como formas simplesmente (SANTOS, 1978, 1990; 1979a; 1996) ${ }^{104}$.

Este raciocínio é uma abordagem possível para entendermos, sob uma perspectiva geográfica, o plano de estabilização da moeda instalado em 1994 no País, o chamado "Plano Real". Se pensarmos nos novos atores e sistemas técnicos que são acoplados às infra-estruturas produtivas, assim como nas novas formas de organização do território que se estabelecem a partir deste evento, veremos que a "estabilidade macroeconômica da moeda" não é o único (e talvez nem o principal) novo conteúdo que passa a fazer parte do espaço nacional ${ }^{105}$.

\footnotetext{
104 Sem considerarmos as ações que incidem sobre as formas, em cada período histórico, não se pode depreender a dialética do espaço (e da sociedade): “(...) Tornada forma-conteúdo pela presença da ação, a forma torna-se capaz de influenciar, de volta, o desenvolvimento da totalidade, participando, assim, de pleno direito, da dialética social”(SANTOS, 1996:101). Ver Santos (1979a:153 e ss.), que mostra ainda que em relação aos países da periferia do capitalismo, na maior parte dos casos, "a nova forma chega junto com um conteúdo importado. Ela contem um modo de produção específico como parte de seu conteúdo. A incorporação de uma nova forma à formação sócio-econômica significa a incorporação de seu conteúdo à mesma formação sócio-econômica"(SANTOS, 1979a:164).

${ }^{105}$ A maior parte da bibliografia analisada sobre as conseqüências do Plano Real indica que o controle dos mecanismos que geravam a inflação foi o mais importante resultado do Plano; uma das exceções é o livro de Gilberto Felisberto Vasconcellos (1997). Com uma visão mais crítica e abrangente, assevera o autor que "o que está na base da criação do Real é a renegociação da dívida externa. O setor financeiro, comandado de fora, domina a sociedade brasileira. (...) Internamente, o domínio do capital financeiro quer acabar com o sentido de missão da carreira pública com 0 fim do intelectual: a nação reduzida a mercado"(VASCONCELLOS, 1997:171). Pareceu-nos, portanto, um raciocínio concatenado com o entendimento de que vivemos um período de passagem de "uma política de Estado para uma política de mercado", como preconiza também o geógrafo Milton Santos (2000; 2001).
} 
O Plano Real, tornando as condições macroeconômicas mais interessantes para alguns atores hegemônicos nacionais, assim como para vários tipos de capitais globalizados, pode ser entendido como um vetor que aumenta a eficácia da instalação dos eventos econômicos globalizados no território brasileiro. Neste sentido, ele pode ser visto ainda como um conteúdo do espaço nacional que aumenta a "atratividade econômica" (MICHALET, 1993) da formação socioespacial brasileira para os investimentos globalizados.

Mas o Plano Real teve também profundas conseqüências para a organização das atividades culturais, políticas e econômicas no âmbito interno do território. Um dos ramos de atividade que mais fizeram sentir essas mudanças, foi, sem sombra de dúvida, o sistema bancário. Roberto Troster (2004:11) afirma que o Plano Real trouxe "uma mudança sem paralelos na nossa história bancária", assim como a empresa de consultoria McKinsey assevera que "desde a estabilização um terremoto sacudiu as instituições financeiras" brasileiras (INSTITUTO MCKINSEY, 2000:76). Quais as conseqüências principais da estabilização da moeda para a organização da atividade bancária no Brasil?

De maneira esquemática, Alkimar Moura (1998:30) lista três principais mudanças trazidas para o sistema bancário, a partir da implementação do Plano Real:

1) ocorrera um decréscimo expressivo das taxas de inflação; esta queda, por sua vez, diminuiu num primeiro momento os ganhos das instituições financeiras instaladas no território, que tinham a maior parte de suas receitas no chamado "lucro inflacionário" (como vimos no item 7.4);

2) com o Plano, incrementou-se também a "abertura financeira externa" do país. A crescente absorção de empréstimos internacionais, ocorrida desde as décadas de 1970 e 1980, e as crescentes dificuldades para o pagamento desse endividamento pressionaram fortemente o Governo Federal para abrir as fronteiras do território para os fluxos de capital estrangeiro de todos os tipos (Investimentos Externos Diretos (IDE's), investimentos no mercado de capitais etc.); 
3) foi criada uma "rede de segurança" para o sistema financeiro nacional, já que a estabilização macroeconômica e a abertura do mercado financeiro aumentaram a necessidade de "criação de mecanismos de proteção mais eficazes e abrangentes" para o sistema montado (MOURA, 1998:30) ${ }^{106}$.

Não nos parece exagero, destarte, estabelecer um nexo causal entre os processos de liberalização (normativa, econômica e financeira) e de privatização/desnacionalização com o Plano Real. Há uma conexão causal direta entre estes fenômenos, passível de ser explicitada pela análise da dinâmica territorial brasileira. Obviamente o Plano teve também conseqüências sensíveis para a população brasileira como um todo, principalmente pelo fato de ter aumentado o acesso a certos bens de consumo para populações de baixa renda (ROCHA, 1999). Mas o processo de estabilização da moeda trouxe, fundamentalmente, a melhoria do chamado "ambiente de investimento" para os grandes atores do cenário econômico globalizado. Este raciocínio permite que pensemos no Plano Real como uma estratégia para aumentar a funcionalidade do território brasileiro para os grandes atores da economia global.

Além do Plano Real, que pode ser considerado um novo conteúdo econômico $e$ político do território brasileiro, houve também uma série de políticas públicas voltadas exclusivamente para a "reestruturação" do sistema bancário brasileiro. Sob forte influência dos novos critérios de segurança dos "Acordos da Basiléia" (PUGA, 1999:449 e ss.), o Governo Federal à época (sob comando do expresidente Fernando Henrique Cardoso) vai implementar dois planos para o "saneamento do sistema bancário nacional". Esses Planos foram o PROES

106 Os controles sobre o sistema bancário de todos os países do mundo são bastante intensificados na década de 1990. Em função da maior mobilidade de fluxos de capital e da liberalização normativa, aumentou também a instabilidade do sistema financeiro global (GOLDFINGER, 1987). Um evento global que representa bem esse aumento dos controles sobre a atividade bancária são os chamados "Acordos de Basiléia". O primeiro grande acórdão deste organismo foi estabelecido em 1988, mas durante toda a década de 1990, assim como nos primeiros anos deste século XXI, várias novas normas são implementadas pelo "Acordo". Segundo Freitas e Prates (2003:243), as normas dizem respeito principalmente a três pontos centrais da atividade bancária: a) requerimento de capitais mínimos para o funcionamento das instituições; b) supervisão constante da adequação destes capitais; e c) "fortalecimento da disciplina de mercado" nas instituições. Ainda segundo as autoras (FREITAS e PRATES, op. cit::245), "o Comitê da Basiléia considera que a segurança e a higidez do sistema financeiro em um mundo dinâmico e complexo só podem ser obtidas com a combinação de supervisão, disciplina de mercado e efetiva administração interna dos bancos". 
(Programa de Incentivo à Redução do Estado na Atividade Bancária) e o PROER (Programa de Estímulo à Reestruturação e ao Fortalecimento do Sistema Financeiro Nacional.

\subsection{A ação do Estado para a privatização do setor financeiro público: o PROES}

Conforme vimos no item 8.4, a psicosfera que em grande parte pautou as principais políticas públicas federais na década de 1990 teve forte influência de algumas ideologias específicas. Estas ideologias não viam como um dado estratégico o controle nacional de parte significativa das infra-estruturas do território. Aliás, passa-se ao entendimento de que a despatrimonialização do Estado poderia ser uma das formas de serem resolvidos dois problemas recorrentes da história brasileira: a questão do endividamento e a da manutenção da estabilidade monetária.

Era do entendimento de elite política nacional que a superação da crise (ou da estagnação) econômica pela qual passava o Brasil teria de se dar em função dos seguintes processos:

a) havia uma quantidade excessiva de empresas estatais (nas três esferas da federação - municipal, estadual e federal), nas áreas produtiva e financeira; boa parte destas empresas causavam "déficits" nas contas públicas, pois eram empresas com sérias deficiências administrativas e de gestão. Os déficits crônicos gerados, por seu turno, impediam que o Estado produzisse o chamado "superávit primário" para o Tesouro;

b) na ausência desse "superávit primário" (e com as chamadas "despesas sociais" crescendo junto ao crescimento populacional), os recursos necessários ao financiamento das atividades estatais acabavam sendo supridos com o aumento da dívida pública (basicamente, com a colocação de títulos do Governo Federal no mercado de capitais), ou com a emissão de moeda; 
c) sendo estas duas formas de política econômica geradoras de inflação, parecia necessário cortar os gastos realizados pelo Estado brasileiro, e a privatização das empresas estatais foi a solução encontrada, pois: 1) as privatizações representariam um corte nas despesas dos Tesouros (Federal e estaduais, principalmente), já que com a venda das estatais não seria mais necessário o aporte de recursos constante para a manutenção delas; 2) a privatização dos principais sistemas de engenharia e instituições bancárias geraria uma quantidade suficiente de recursos para saldar compromissos de dívidas acumuladas do Estado. Seria assim resolvida a questão fiscal, que permitiria ao Estado incrementar o pagamento de suas dívidas e realizar a estabilidade de moeda.

É sob esse conjunto de crenças e entendimentos da elite política de meados de 1990 que os bancos oficiais brasileiros passaram a ser vistos como um dos pilares desta impossibilidade de "superação da crise". O Banespa, em particular, era tido como uma das principais instituições que impediam a resolução da crise fiscal e do processo inflacionário no país (GARMAN, LEITE e MARQUES, 1998). Mas não só o Banespa, e sim toda a rede de bancos públicos estaduais é que causariam a instabilidade da moeda (WERLANG e FRAGA NETO, 1995; WERNECK, 1995; FRANCO, 1999). Para um desses autores, o processo de privatização das instituições financeiras públicas se constituía em "uma oportunidade de ouro de erradicar essa doença (sic) chamada banco estadual”(FRANCO, 1999) do sistema financeiro brasileiro ${ }^{107}$.

Neste contexto é implementada a principal política pública do Governo Federal para o setor financeiro, no ano de 1996. Esse evento, que culminou com

\footnotetext{
107 As privatizações de bancos estaduais não ocorreram apenas no Brasil. Na Argentina, a geógrafa María Laura Silveira (1999:372) nos mostra que na década de 1990 se dá uma "reestruturação bancária regional", e a privatização do Banco Provincial de Neuquén é um exemplo bem acabado das conseqüências desta "reestruturação". Armijo e Jha (1997) descrevem também para a Índia processo semelhante. Para um apanhado bastante completo (mas pouco crítico) do processo de privatizações bancárias no mundo, ver Megginson (2003).
} 
praticamente a aniquilação do sistema de bancos públicos estaduais no Brasil, foi o Programa de Incentivo à Redução do Estado na Atividade Bancária (PROES) ${ }^{108}$.

Resultado da edição da Medida Provisória no. 1.514, de 07/08/1996, o PROES tinha como objetivo "reduzir ao mínimo a presença de instituições financeiras controladas pelos governos estaduais no sistema financeiro"(SALVIANO ]r., 2004:81). Através do PROES, o Governo Federal oferecia financiamentos em longo prazo para que os Estados da federação saneassem (ou diminuíssem sensivelmente) seu endividamento.

Este endividamento era de fato bastante significativo, principalmente nos Estados de São Paulo, Rio de Janeiro e Minas Gerais. Mas as causas remotas dele vinham das próprias deficiências estruturais do federalismo fiscal e financeiro brasileiro. Expliquemos melhor. Desde ao menos o ano de 1964 o federalismo fiscal montado no país centralizava os impostos mais dinâmicos sob controle da União (OLIVEIRA, 1991; 1995). Aos Estados - principalmente aqueles mais populosos - restavam recursos insuficientes da partilha das receitas fiscais totais, para manter suas políticas públicas regionais (nas áreas de educação, habitação, saúde etc.). Desde a década de 1970, portanto, os Estados da federação passam a fazer uso sistemático de seus bancos públicos, tendo no processo de endividamento uma forma para a manutenção da prestação de serviços públicos essenciais (MORA, 2002) ${ }^{109}$.

Este endividamento estadual, porém, chega a níveis considerados incontroláveis ao final da década de 1990. Em função da própria política de juros altos implementada pelas Autoridades Monetárias nos primeiros anos do Plano Real, boa

\footnotetext{
${ }^{108}$ O Governo Federal, desde ao menos o ano de 1983 vinha tentando implementar - sem o sucesso esperado - "diversos programas de saneamento dos bancos estaduais", como nos lembra Fernando Puga (1999). Dentre eles, podemos destacar: Programa de Apoio Creditício (PAC), de 1983; Programa de Recuperação Financeira (PROREF), em 1984; em 1986 são acoplados o PAC e o PROREF; Regime de Administração Especial Temporária (RAET), em 1987; Programa de Recuperação, em 1990; e finalmente uma "linha especial para os bancos liquidados em 1990, vinculada a ajustes"(PUGA, 1999:424), no ano de 1992.

${ }^{109}$ Como lembra-nos Mônica Mora (2002:5), “o endividamento estadual iniciou-se na década de 1970 como alternativa à gestão tributária centralizadora, característica do governo militar. A Reforma Tributária de $1966 \mathrm{e}$ a Reforma Administrativa de 1967 participaram do processo de esvaziamento político-econômico dos governos sub-nacionais".
} 
parte dos Estados vêem os serviços de suas dívidas se tornarem impagáveis (LOPREATO, 2002). Daí o recurso ao PROES ser uma das alternativas para sanear a situação financeira dos governos estaduais.

Com o PROES, os governadores passam a contar com a possibilidade de terem suas dívidas financiadas pelo Governo Federal, num prazo mais longo. Em contrapartida, teriam que se desfazer de seus Bancos (BAER e NAZMI, 2000; MAKLER, 2000; NESS Jr., 2000), assim como de outros ativos (ferrovias, prédios públicos, centrais de abastecimento etc.). Como mostra Vera Brisbane [s/d:5859), assim que os governos estaduais e/ou municipais aderissem ao PROES, "em troca, o Tesouro Nacional financiaria $50 \%$ ou $100 \%$ das dívidas do Estado ou Município com os bancos que controlavam, a um custo variável de rolagem de $6 \%$ a.a. (ao ano) mais atualização do saldo pendente pelo IGP-DI"110.

Com a adesão dos governadores ao PROES, eram possíveis quatro encaminhamentos para as instituições financeiras estaduais:

a) extinção da instituição financeira;

b) privatização;

c) transformação em instituição não-financeira (agência de fomento);

d) federalização (aquisição do controle pela União, que posteriormente privatizaria ou extinguiria a instituição);

e) saneamento da instituição (SALVIANO ]r., 2004:84).

A "extinção" se daria com as instituições "já liquidadas extrajudicialmente" (SALVIANO ]r.,2004:84); tratavam-se de bancos importantes em seus contextos regionais (basicamente bancos estaduais das unidades menos desenvolvidas da federação), mas com pouca expressão para as contas públicas nacionais em seu conjunto. A tabela abaixo nos mostra quais foram as instituições extintas (entre

110 O Índice Geral de Preços (IGP) é um "índice de inflação calculado pela Fundação Getúlio Vargas (FGV)", e que leva em consideração a variação dos preços das mercadorias vendidas no atacado, no varejo, assim como da variação dos preços praticados na indústria da construção civil (BIDERMAN, 2006:238). 
Bancos Comerciais Estaduais, Bancos de Desenvolvimento e Caixas Econômicas), ou em processo de liquidação judicial:

Quadro 4: Brasil: Instituições financeiras estaduais extintas/em liquidação ordinária (2002)

\begin{tabular}{|l|l|}
\hline Em liquidação & Banacre (AC) \\
\hline & Banap (AP) \\
\hline & Bandern (RN) \\
\hline & BDRN (RN) \\
\hline & Bemat (MT) \\
\hline & Beron (RO) \\
\hline & Caixego (GO) \\
\hline & Minascaixa (MG) \\
\hline & Produban (AL) \\
\hline Extinto & \\
\hline & Baner (RR) \\
\hline
\end{tabular}

Fonte: Banco Central. Relatório de Atividades da Diretoria de Fiscalização (1995-2002)

Outra opção colocada pelos técnicos do Ministério da Fazenda e do Banco Central no âmbito do PROES era a da transformação das instituições financeiras estaduais em "agências de fomento". Estas, por sua vez, não teriam a prerrogativa de agir como um banco comercial e "captar depósitos junto ao público", como é função precípua de todos os bancos comerciais (REED e GILL, 1986). Perdia-se assim também a possibilidade de serem comandados regionalmente os recursos financeiros passíveis de captação local.

A partir do momento em que se constituem em Agências de Fomento, os antigos bancos estaduais passam a ser considerados ainda - do ponto de vista jurídico como "instituições não-financeiras". A grande novidade, no que diz respeito à ação das "Instituições não-financeiras", é que estas não podem se endividar, como era o caso dos bancos estaduais. Seu controle financeiro, por parte das Autoridades Monetárias é, assim, bastante otimizado.

Foram criadas, no âmbito do PROES, as seguintes Agências de Fomento ${ }^{111}$ : a) Agência de Fomento do Amapá

111 Esta lista foi feita a partir das informações de Cleofas Salviano Jr, (2004) e do Relatório de Atividades da Diretoria de Fiscalização (1995-2002), do Banco Central (2006). 
b) Agência de Fomento do Amazonas

c) Agência de Fomento do Paraná

d) Agência de Fomento de Roraima

e) Agência de Fomento de Rondônia

f) Agência de Fomento do Rio Grande do Norte

g) Agência Catarinense de Fomento (BADESC)

h) Caixa Estadual S/A - Agência de Desenvolvimento do Rio Grande do Sul

i) Desembahia

j) Goiás Fomento

k) Agência de Fomento do Acre

I) Agência de Fomento de Alagoas

m) Agência de Fomento do Mato Grosso

n) Agência de Fomento do Piauí

o) Agência de Fomento de Pernambuco

Importa destacar ainda - como nos lembra Carlos Gutierrez (2006) - que a utilização de Agências de Fomento como mecanismo de desenvolvimento regional (em lugar dos Bancos Estaduais) padece ao menos de dois problemas importantes. Em primeiro lugar, como não são autorizadas por lei a estender uma rede de captação de depósitos, funcionam apenas com uma agência (que é também a sede da instituição). Por se constituírem em instituições "monocéfalas", as Agências de Fomento acabam por estabelecer uma relação menos orgânica com o território no qual estão instaladas.

Além da questão da topologia, há também uma "restrição funcional" das Agências de Fomento, em relação aos bancos comerciais estaduais. Os recursos dos quais passam a dispor as Agências são basicamente recursos repassados de instituições nacionais (BNDES) e internacionais (Banco Mundial). Na maior parte das vezes, esses repasses ou empréstimos já vêm com uma destinação específica, planejada em contextos que não têm relação direta com as realidades regionais sobre as quais têm que trabalhar as Agências. Um exemplo deste "controle externo" do 
financiamento é a destinação de vários financiamentos do Banco Mundial para a construção de "Arranjos Produtivos Locais" (SALVIANO Jr., 2004), nas áreas de atuação das referidas instituições.

Através da criação das Agências de Fomento, portanto, o uso do território nas regiões não necessariamente é decidido pelas próprias autoridades políticas ou econômicas estaduais. Em uma palavra: há perda de soberania das unidades federativas, já que a decisão sobre os recursos disponíveis não se realiza mais na escala do sistema de ações público de cada parcela do território ${ }^{112}$.

\begin{abstract}
Além da extinção, transformação em Agência de Fomento, o PROES disponibilizava a opção da privatização das instituições estaduais ${ }^{113}$. A privatização, por seu turno, poderia se dar de duas formas: a) através da privatização direta, isto é, conduzida pelos próprios estados controladores dos bancos; ou b) de forma indireta, isto é, através da federalização das instituições, para sua posterior privatização. As seguintes instituições financeiras (bancos estaduais e demais sistemas de ação a eles ligados) foram privatizadas diretamente pelos Estados:
\end{abstract}

\footnotetext{
112 Como lembra também Cleofas Salviano Jr., "as agências são limitadas a uma por estado, e destinam-se a financiar projetos na área do estado a que pertencem, não podendo captar depósitos do público, não tendo acesso a operações de redesconto no Banco Central nem tendo conta de reservas bancárias. Elas apenas podem emprestar capital próprio, repassar recursos orçamentários, de fundos constitucionais e de organizações de desenvolvimento nacionais ou internacionais"(2004:85).

113 A bem da verdade, esse era o "ethos" da reforma do sistema financeiro produzida pelo sistema de ações do governo federal. Interessava ao Executivo Federal a privatização completa destas instituições estaduais pois como mencionamos - a União passa a enxergá-las como principais causadoras da dificuldade do desenvolvimento do país. No que tange a privatização das instituições bancárias estaduais, cada caso teve uma série de especificidades, que não caberia descrever no contexto desta tese. Importa destacar que, sem exceção, as receitas obtidas pelos estados eram imediatamente utilizadas na amortização do financiamento das dívidas estaduais, dentro do PROES.
} 
Quadro 5: Brasil: Bancos Estaduais Privatizados Diretamente no Âmbito do PROES (1996-2001)

\begin{tabular}{|c|c|}
\hline BANCO PÚBLICO PRIVATIZADO & $\begin{array}{l}\text { INSTITUIÇÃO FINANCEIRA COMPRADORA } \\
\text { E DADOS DO BANCO ADQUIRIDO }\end{array}$ \\
\hline BANER] & $\begin{array}{l}\text { Comprador: Itaú (1997) } \\
\text { Valor total pago: } \mathrm{R} \$ 311 \text { milhões } \\
\text { No. de funcionários: sem dados } \\
\text { No. de Agências: } 190\end{array}$ \\
\hline $\begin{array}{l}\text { CREDIREAL } \\
\text { - Credireal CCVM } \\
\text { - Credireal Leasing }\end{array}$ & $\begin{array}{l}\text { Comprador: BCN/Bradesco (1997) } \\
\text { Valor total pago: } \mathrm{R} \$ 134 \text { milhões } \\
\text { No. de funcionários: } 2.413 \\
\text { No. de Agências: } 86\end{array}$ \\
\hline $\begin{array}{l}\text { BEMGE } \\
\begin{array}{l}\text { - Bemge DTVM } \\
\text { - EFI BEMGE }\end{array}\end{array}$ & $\begin{array}{l}\text { Comprador: Itaú (1998) } \\
\text { Valor total pago: } \mathrm{R} \$ 603 \text { milhões } \\
\text { No. de funcionários: sem dados } \\
\text { No. de Agências: sem dados }\end{array}$ \\
\hline $\begin{array}{c}\text { Banco do Estado de Pernambuco } \\
\text { (BANDEPE) } \\
\text { - BANDEPE Distribuidora de } \\
\text { Títulos e Valores }\end{array}$ & $\begin{array}{l}\text { Comprador: ABN/AMRO (1998) } \\
\text { Valor total pago:R\$ } 183 \text { milhões } \\
\text { No. de funcionários: } 1.641 \\
\text { No. de Agências: } 52\end{array}$ \\
\hline $\begin{array}{c}\text { Banco do Estado da Bahia (BANEB) } \\
\text { - BANEB Financeira } \\
\text { - BANEB Crédito Imobiliário } \\
\text { - BANEB CCVM } \\
\text { - Dibahia BANEB DTVM } \\
\text { - BANEB Leasing }\end{array}$ & $\begin{array}{l}\text { Comprador: Bradesco (1999) } \\
\text { Valor total pago: } R \$ 267 \text { milhões } \\
\text { No. de funcionários: } 2.825 \\
\text { No. de Agências } 170\end{array}$ \\
\hline $\begin{array}{l}\text { BANESTADO } \\
\text { - Banestado Leasing } \\
\text { - Banestado CVM } \\
\text { - Banco del Paraná }\end{array}$ & $\begin{array}{l}\text { Comprador: Itaú (2000) } \\
\text { Valor total pago: } \mathrm{R} \$ 1,8 \text { bilhão } \\
\text { No. de funcionários: } 7.683 \\
\text { No. de Agências: } 376\end{array}$ \\
\hline PARAIBAN & $\begin{array}{l}\text { Comprador: ABN/AMRO (2001) } \\
\text { Valor total pago: } \mathrm{R} \$ 79 \text { milhões } \\
\text { No. de funcionários: } 390 \\
\text { No. de Agências/PAB's: } 16\end{array}$ \\
\hline
\end{tabular}

Fonte: Banco Central - Instituições Privatizadas (2006); SALVIANO Jr. (2004) 
Estas são, portanto, as instituições diretamente privatizadas pelos seus próprios controladores (os Estados da federação). Vale destacar que a venda do BANER], ainda no ano de 1997, teve importância ímpar no processo de aniquilação do sistema estadual de Bancos públicos. Como mostram Makler (2000) e Cleofas Salviano Jr. (2004), o sucesso relativo da operação com o BANER] possibilitou que investidores nacionais e internacionais aumentassem seu interesse para a aquisição eventual dos demais bancos.

Faz-se mister ressaltar que nos três principais estados da federação existiam governadores do mesmo partido que o do Executivo Federal (o Partido da Social Democracia Brasileira - PSDB): Mário Covas governava São Paulo, Marcelo Alencar o Rio de Janeiro e Eduardo Azeredo o Estado de Minas Gerais. Daí a maior facilidade na implementação dos programas de privatização dos bancos estaduais no território. Parte da bibliografia destaca o fato de que a privatização nesta parcela do território seria também um elemento de pressão para que os demais estados da federação se sentissem "coagidos" a privatizar suas instituições financeiras ${ }^{114}$.

Para completarmos o quadro de privatizações dos bancos estaduais, faz-se necessário destacar os bancos cujo controle foi inicialmente transferido para a União (processo de federalização), para a posterior privatização.

114 Os demais bancos privatizados, conforme frisamos, necessitaram ser antes "federalizados", para que a ação do Executivo Federal saneasse as contas destes sistemas de ação, tornando-os "atrativos" para os potenciais compradores (NESS, 2000). 
Quadro 6: Brasil: Bancos Estaduais Privatizados Após Federalização no Âmbito do PROES (1996-2006)

\begin{tabular}{|c|c|}
\hline BANCO PÚBLICO PRIVATIZADO & \begin{tabular}{llll} 
INSTITUIÇÃO & & \multicolumn{2}{c}{ FINANCEIRA } \\
COMPRADORA E DADOS & DO BANCO \\
ADQUIRIDO & &
\end{tabular} \\
\hline $\begin{array}{l}\text { Banco do Estado de São Paulo (BANESPA) }{ }^{115} \\
\text { - Banque Banespa Internacional } \\
\text { - Banescor } \\
\text { - Banesleasing }\end{array}$ & $\begin{array}{l}\text { Comprador: Santander (2000) } \\
\text { Valor total pago: R\$ 7,16 bilhões } \\
\text { No. de funcionários: } 20.098 \\
\text { No. de Agências/PAB's: } 1.330\end{array}$ \\
\hline Banco do Estado do Amazonas (BEA) & $\begin{array}{l}\text { Comprador: Bradesco (2002) } \\
\text { Valor total pago: } \mathrm{R} \$ 192 \text { milhões } \\
\text { No. de funcionários: sem dados } \\
\text { No. de Agências/PAB's: sem dados }\end{array}$ \\
\hline $\begin{array}{l}\text { Banco do Estado de Goiás } \\
\qquad- \text { BEG Distribuidora de Títulos e } \\
\text { Valores Mobiliários }\end{array}$ & $\begin{array}{l}\text { Comprador: Itaú (2001) } \\
\text { Valor total pago: } \mathrm{R} \$ 680 \text { milhões } \\
\text { No. de funcionários: sem dados } \\
\text { No. de Agências/PAB's: } 151\end{array}$ \\
\hline Banco do Estado do Maranhão & $\begin{array}{l}\text { Comprador: Bradesco (2004) } \\
\text { Valor total pago: } \$ \text { \$ } 82 \text { milhões } \\
\text { No. de funcionários: sem dados } \\
\text { No. de Agências/PAB's: sem dados }\end{array}$ \\
\hline Banco do Estado do Ceará & $\begin{array}{l}\text { Comprador: Bradesco (2005) } \\
\text { Valor total pago: } \mathrm{R} \$ 700 \text { milhões } \\
\text { No. de funcionários: } 863 \\
\text { No. de Agências/PAB's: } 69\end{array}$ \\
\hline
\end{tabular}

Fonte: Banco Central - Instituições Privatizadas (2006); SALVIANO Jr. (2004); Jornal O GLOBO (22/12/2005); Boletim FOCUS (Banco Central, 2001)

Estas foram, portanto, as instituições financeiras antes sob controle estadual, que passaram a ser propriedade de bancos privados, nacionais ou estrangeiros. $\mathrm{O}$ aniquilamento da rede de bancos públicos estaduais só não foi maior pois alguns

\footnotetext{
115 Dada a complexidade da privatização do Banespa, vale lembrar que sua venda não se deu no âmbito do PROES, pois requereu por parte do Governo Federal um longo processo de negociações para que a privatização fosse concluída. Ver Garman, Leite e Marques (1998).
} 
estados conseguiram manter sob seu comando suas instituições financeiras. Dentre as instituições que foram passíveis de serem apenas "saneadas" pelo PROES, estão:

1) Banco do Estado de Sergipe (BANESE);

2) Banco do Estado do Espírito Santo (BANESTES)

3) Banco do Estado do Pará (BANPARÁ)

4) Nossa Caixa (Caixa Econômica do Estado de São Paulo)

5) Banco de Desenvolvimento do Estado de Minas Gerais (BDMG)

6) Banrisul

7) Banco do Estado do Piauí (BEP)

8) Banco do Estado de Santa Catarina (BESC)

9) Banco do Desenvolvimento do Espírito Santo (BANDES)

10) Banco Regional de Brasília

A maior parte destas instituições encontra-se, do ponto de vista burocrático e legal, prontas para serem privatizadas. É o caso, principalmente, do Banco do Estado do Espírito Santo, do Banco do Estado do Pará, Banco do Estado do Piauí e do Banco do Estado de Santa Catarina.

Quais as conseqüências para as contas públicas da nação, no que diz respeito às alterações implementadas pelo PROES? Quais os montantes despendidos no processo de rearranjo do sistema bancário estadual, e qual a distribuição regional dos gastos da União, para a instalação deste novo modus operandi do federalismo financeiro brasileiro?

Desde o início do PROES, no ano de 1997, uma quantidade vultosa de recursos do Governo Federal foi gasta para a consecução do Programa, como mostra a tabela abaixo. 
Tabela 19: Brasil: Evolução dos Recursos Gastos com o PROES (Títulos emitidos em R\$ milhões) (1996-2004)

\begin{tabular}{|c|c|c|c|}
\hline Estado & $\begin{array}{l}\text { Data da } \\
\text { Emissão }\end{array}$ & Valor Emitido & $\begin{array}{c}\text { Totais gastos por } \\
\text { Estado (em R\$ } \\
\text { milhões) }\end{array}$ \\
\hline Acre & 29.03 .99 & 131,07 & 131,07 \\
\hline Alagoas & $\begin{array}{l}16.10 .02 \\
16.10 .02 \\
\end{array}$ & $\begin{array}{r}457,00 \\
45,00\end{array}$ & 502,00 \\
\hline Amapá & $\begin{array}{l}29.12 .98 \\
24.02 .99 \\
\end{array}$ & $\begin{array}{r}24,85 \\
4,00 \\
\end{array}$ & 28,85 \\
\hline Amazonas & \begin{tabular}{|l|}
02.08 .99 \\
25.08 .99 \\
06.09 .00 \\
\end{tabular} & $\begin{array}{r}312,55 \\
51,10 \\
53,27 \\
\end{array}$ & 416,92 \\
\hline Bahia & \begin{tabular}{|l|}
01.06 .98 \\
25.06 .98 \\
03.10 .01
\end{tabular} & $\begin{array}{r}164,53 \\
1.433,06 \\
113,41\end{array}$ & $1.711,00$ \\
\hline Ceará & 27.05 .99 & 984,72 & 984,72 \\
\hline Espírito Santo & 25.11 .98 & 260,36 & 260,36 \\
\hline Goiás & \begin{tabular}{|l|}
27.05 .99 \\
20.06 .00 \\
04.10 .00 \\
\end{tabular} & $\begin{array}{r}476,21 \\
60,00 \\
65,14 \\
\end{array}$ & 601,35 \\
\hline Maranhão & \begin{tabular}{|l|}
15.12 .98 \\
13.01 .99 \\
10.02 .04 \\
\end{tabular} & $\begin{array}{r}29,82 \\
302,14 \\
22,47 \\
\end{array}$ & 359,43 \\
\hline Mato Grosso & $\begin{array}{l}22.01 .99 \\
12.05 .04 \\
\end{array}$ & $\begin{array}{r}193,11 \\
4,00 \\
\end{array}$ & 197,11 \\
\hline Minas Gerais & \begin{tabular}{|l|}
15.06 .98 \\
16.06 .98 \\
24.06 .98 \\
02.07 .98 \\
06.08 .98 \\
19.08 .98 \\
04.05 .00 \\
\end{tabular} & $\begin{array}{r}336,38 \\
616,12 \\
2.280,38 \\
329,45 \\
172,06 \\
902,84 \\
59,96\end{array}$ & $4.697,19$ \\
\hline Pará & 22.01 .99 & 127,41 & 127,41 \\
\hline Paraná & \begin{tabular}{|l|}
05.03 .99 \\
16.06 .99 \\
01.12 .99 \\
05.12 .99 \\
\end{tabular} & $\begin{array}{r}2.687,36 \\
136,75 \\
735,01 \\
1.638,51 \\
\end{array}$ & $5.197,63$ \\
\hline Pernambuco & \begin{tabular}{|l|}
15.08 .98 \\
27.08 .98
\end{tabular} & $\begin{array}{l}328,66 \\
915,74\end{array}$ & $1.244,40$ \\
\hline
\end{tabular}

Fonte: Banco Central do Brasil. Supervisão e Saneamento 2006.

1 - valores financiados fora do âmbito do PROES. 
Tabela 19: Brasil: Evolução dos Recursos Gastos com o PROES (Títulos emitidos em R\$ milhões) (1996-2004) continuação

\begin{tabular}{|c|c|c|c|}
\hline Piauí & \begin{tabular}{|l|}
24.02 .00 \\
06.09 .00 \\
\end{tabular} & \begin{tabular}{l|}
69,08 \\
76,80 \\
\end{tabular} & 145,88 \\
\hline Rio de Janeiro (1) & 31.05 .98 & $3.879,70$ & $3.879,70$ \\
\hline Rio Grande do Norte & $\begin{array}{l}18.03 .99 \\
22.12 .99 \\
\end{array}$ & $\begin{array}{r}100,94 \\
4,00 \\
\end{array}$ & 104,94 \\
\hline Rio Grande do Sul & $\begin{array}{l}10.12 .98 \\
05.07 .00 \\
\end{array}$ & $\begin{array}{r}2.379,88 \\
176,27 \\
\end{array}$ & $2.556,15$ \\
\hline Rondônia & 20.05 .98 & 549,20 & 549,20 \\
\hline Roraima & 18.02 .99 & 39,98 & 39,98 \\
\hline Santa Catarina & \begin{tabular}{|l|}
29.03 .99 \\
05.05 .99 \\
07.08 .00 \\
30.08 .00 \\
01.03 .02 \\
26.03 .02 \\
06.09 .02 \\
26.09 .02 \\
26.09 .02 \\
09.10 .02 \\
10.10 .02 \\
15.10 .02 \\
\end{tabular} & $\begin{array}{r}197,76 \\
68,48 \\
779,97 \\
0,02 \\
89,62 \\
28,20 \\
62,80 \\
20,49 \\
349,99 \\
357,82 \\
41,59 \\
23,17 \\
\end{array}$ & $2.019,91$ \\
\hline São Paulo (1) & \begin{tabular}{|l|}
23.12 .97 \\
24.12 .97 \\
\end{tabular} & $\begin{array}{r}33.578,50 \\
2.458,00 \\
\end{array}$ & $36.126,50$ \\
\hline Sergipe & 18.01 .99 & 40,98 & 40,98 \\
\hline Total & & $61.922,68$ & $61.922,68$ \\
\hline
\end{tabular}

Fonte: Banco Central do Brasil. Supervisão e Saneamento 2006.

1 - valores financiados fora do âmbito do PROES.

Durante os cinco anos do PROES, quase R\$ 62 bilhões foram gastos com esta alteração patrimonial dos bancos estaduais. Chama-nos a atenção não só por seus valores brutos, mas também porque esta despatrimonialização bancária foi financiada - como já frisado - com a emissão de títulos da dívida pública federal. Isto é, além de aumentar a dívida interna do país, o processo de emissão de papéis incrementa o processo de "titularização" dos ativos e passivos nacionais.

Dadas estas novas condições normativas e organizacionais do sistema financeiro brasileiro, várias foram as instituições (nacionais e estrangeiras) que se interessaram pela aquisição de Bancos no País. Assim como no caso do Plano Real, o PROES pode ser considerado também como uma política que aumentou o 
interesse dos investidores nacionais e (principalmente) internacionais, em relação ao sistema bancário brasileiro.

Mas esse interesse se deu também pelas próprias características da topologia dos bancos em questão. Em primeiro lugar, era bastante interessante a aquisição das instituições financeiras estaduais pois estas possuíam redes de agências já consolidadas, e muito bem distribuídas (tanto nas capitais quanto no interior dos Estados). Por serem redes de agências há tempos construídas, a maior parte das agências destes bancos possui localização privilegiada, seja no que diz respeito à rede urbana de cada Estado, como no próprio tecido urbano no qual estão instalados os pontos de atendimento.

O Banespa, como vimos, iniciara suas atividades no território ainda no ano de 1909, e desde então vem constituindo uma topologia que atinge os pontos mais dinâmicos do Estado de São Paulo. A localização das agências era um ativo interessantíssimo aos compradores, e não constou na definição do preço do Banco, como mostra estudo do Departamento Intersindical de Estatísticas e Estudos Socioeconômicos (DIEESE) ${ }^{116}$.

Um segundo fator que atraiu investidores para a compra dos bancos estaduais diz respeito ao chamado lucro potencial que as instituições apresentavam. Com a aquisição, passaria a haver possibilidade de manipulação das contas dos Tesouros de cada estado da federação, pela entidade compradora do Banco estadual. Isto é "as contas de depósito dos governos estaduais"(SALVIANO Jr. 2004:119)

\footnotetext{
${ }^{116}$ Segundo o estudo do DIEESE, a metodologia utilizada para a precificação do Banespa considerou principalmente a "avaliação do fluxo de caixa" que o Banco possuiria a partir da privatização. Não foram contabilizados, por exemplo, "seu preço medido em termos de Ativos, Patrimônio Líquido, Depósitos, Agências, Clientes", entre outros (DIESSE, 2000). Advoga o mesmo documento que a moderna rede de pontos de atendimento do banco era composta de "572 agências, 6 Postos Avançados de Atendimento (PAA) e 749 Postos de Atendimento Bancário (PAB), que contavam com 7.464 caixas e 2.406 auto-caixas, todos operando on line e em tempo real"; daí a importância de considerá-la na precificação. Outro aspecto não considerado foi a própria localização do Banco, numa região do território bastante bem servida de uma redesuporte moderna, propícia para as atividades financeiras. Dadas estas diferenças de critérios, os preços estabelecidos para o Banco variavam de $R$ \$ 5,843 bilhões até $R$ \$ 11,996 bilhões. A grande diferença entre os preços propostos, segundo ainda o DIEESE, indicava que novas consultorias deveriam ser contratadas, antes da privatização do banco (DIEESE, 2000). Sobre a importância das empresas de consultoria na reorganização do território na década de 1990, ver também o trabalho de Adriana Bernardes (2001).
} 
passariam a ser gerenciadas pela instituição compradora, tornando-se assim uma fonte de lucros vultosa, se bem aproveitada.

Um terceiro aspecto que envolveu o interesse de grandes investidores pelos bancos estaduais foi a possibilidade de controle das "folhas de pagamento" do funcionalismo público. Tanto no nível estadual, quanto no municipal, a compra dos bancos estaduais poderia abrir uma gama enorme de oportunidades de negócios envolvendo uma clientela bastante interessante. Por se tratarem de funcionários públicos, são considerados uma clientela cativa, com níveis salariais relativamente elevados, e com renda estável (dada sua estabilidade no emprego). Dentre as operações passíveis de serem realizadas com essa "carteira de clientes", estão os empréstimos consignados, a venda de produtos financeiros, cobrança de taxas de manutenção de contas, tarifas de prestação de serviços bancários etc.

Por fim, mas não menos importante, a aquisição dos bancos estaduais abriria a possibilidade de prestação de serviços bancários em grande escala para os Estados ex-controladores dos bancos em questão. Alguns exemplos destes serviços passíveis de serem prestados são: a) processamento das enormes folhas de pagamento dos funcionários públicos; b) pagamento dos fornecedores do Estado; c) cobrança de impostos/taxas públicas etc. A cobrança destas operações se mostrava ainda mais valiosa pois desde o início do Plano Real são as taxas e tarifas um dos principais fatores de remuneração dos bancos, no lugar do "lucro inflacionário". ${ }^{117}$

\subsection{A concentração induzida no sistema bancário privado: o PROER}

Através da Resolução 2.208, de novembro de 1995, foi estabelecido o Programa de Estímulo à Reestruturação e ao Fortalecimento do Sistema Financeiro Nacional (PROER). Segundo Fernando Puga (1999:419), o PROER “contempla a criação de

\footnotetext{
117 Estudando três grandes bancos nacionais (Bradesco, Itaú e Unibanco), Coutinho e Amaral (2003:1031) mostram que no período de 1991 a 2000 "as receitas de tarifas elevaram-se consideravelmente nas três instituições registrando aumento de mais de $100 \%$ em sua participação no total das receitas operacionais das instituições financeiras".
} 
uma linha especial de assistência financeira destinada a financiar reorganizações administrativas, operacionais e societárias de instituições financeiras que resultem na transferência de controle ou na modificação de objeto social para finalidades não-privativas de instituições financeiras".

O PROER possibilitou, segundo o Banco Central, o saneamento de sete instituições financeiras nacionais, sendo três delas consideradas de grande porte. O quadro abaixo mostra os bancos que foram encampados nas operações do PROER:

Quadro 7: Brasil: Bancos Vendidos com Recursos do PROER, por Tipo de Operação (1995-2000)

\begin{tabular}{|l|l|l|ll|}
\hline \multicolumn{1}{|c|}{$\begin{array}{c}\text { Nome do banco } \\
\text { vendido }\end{array}$} & $\begin{array}{l}\text { Banco recebedor dos } \\
\text { ativos }\end{array}$ & \multicolumn{1}{|c|}{ Tipo de peração } \\
\hline 1996 & Banco Econômico & $\begin{array}{l}\text { Banco Excel e Caixa } \\
\text { Econômica Federal }\end{array}$ & venda de ativos \\
\hline 1996 & Banco Nacional & Unibanco & venda de ativos & \\
\hline 1996 & $\begin{array}{l}\text { Banco Mercantil de } \\
\text { Pernambuco }\end{array}$ & Banco Rural & venda de ativos & \\
\hline 1996 & Banco Banorte & Banco Bandeirantes & venda de ativos & de \\
\hline 1996 & $\begin{array}{l}\text { Banco Antonio de } \\
\text { Queiroz }\end{array}$ & Banco United & $\begin{array}{l}\text { transferência } \\
\text { controle acionário }\end{array}$ \\
\hline 1996 & Banco Martinelli & Banco Pontual & $\begin{array}{l}\text { transferência } \\
\text { controle acionário }\end{array}$ \\
\hline 1997 & Banco Bamerindus & $\begin{array}{l}\text { HSBC, CEF e Banco do } \\
\text { Brasil }\end{array}$ & venda de ativos \\
\hline
\end{tabular}

Fonte: Banco Central do Brasil. 1999.

Com o PROER, completou-se o quadro da chamada "reestruturação do sistema financeiro nacional", implementado a partir do ano de 1995. Segundo estudiosos desta "reestruturação" (CARVALHO e OLIVEIRA, 2002), após o Plano Real, alguns importantes bancos do sistema financeiro brasileiro não conseguem alcançar os níveis de rentabilidade que possuíam antes, conseguida com os chamados "lucros inflacionários". Principalmente os três maiores bancos indicados na tabela acima (Econômico, Nacional e Bamerindus) não tiveram "capacidade de reação 
frente à forte mudança provocada pela queda abrupta da inflação"(CARVALHO e OLIVEIRA, 2002:82) ${ }^{118}$.

Tanto em função da qualidade das "carteiras de crédito" dos bancos, como também por problemas em seus "ativos", estas três instituições não mostravam um desempenho satisfatório no que diz respeito às "modernas técnicas bancárias". A ausência de ambiente inflacionário acabou por tornar visíveis estas deficiências, por parte das Autoridades Monetárias, levando à intervenção do Banco Central nas mesmas através do PROER. O temor das Autoridades Monetárias da época vinha da possibilidade de uma destas instituições falirem, o que poderia gerar uma "crise sistêmica" nas finanças nacionais, que traria prejuízos ainda maiores do que os recursos gastos nessa "reestruturação"119.

Há, porém, aspectos importantes destas alterações societárias no âmbito do PROER, que merecem ser destacados. Os três principais bancos que sofreram intervenção (Banco Econômico, Nacional e Bamerindus) eram instituições privadas bastante importantes em seus contextos regionais, além de serem as últimas grandes casas bancárias privadas com sede fora da cidade de São Paulo. O Banco Econômico possuía sua sede na cidade de Salvador (BA), sob controle da família Calmon de Sá. Já o Banco Bamerindus tinha sua sede na cidade de Curitiba (PR), pertencente à família Andrade Vieira, até ser desnacionalizado (foi comprado pelo banco inglês $\mathrm{HSBC}$ ). E, finalmente, o Banco Nacional, que tinha sua sede na capital do estado de Minas Gerais (Belo Horizonte), e pertencia à família Magalhães Pinto.

\footnotetext{
118 Para o caso do Banco Nacional, nota o geógrafo Carlos Franco da Silva (1999) que desde meados da década de 1980 o Banco procurava tanto uma modernização de suas infra-estruturas técnicas quanto de seu modo de funcionamento em relação ao "ambiente macroeconômico" do País. Porém, "apesar de todo esse esforço de acompanhar os avanços da telemática e do radical programa de reestruturação administrativa, o Banco Nacional S/A não conseguiu transformar tais estratégias em lucros e se adaptar à queda da inflação, já que realizava inúmeras operações de crédito bem acima de seu patrimônio e os resultados obtidos eram insatisfatórios. Assim, a crise que teve início após o Plano Cruzado atingiu seu auge em 1995 e determinou o fim do banco"(SILVA, 1999:68).

119 Segundo reportagem do jornal Folha de São Paulo, no ano passado a perda estimada pelo Banco Central com a intervenção através do PROER foi de R\$ 4,75 bilhões. Assim como no caso dos bancos estaduais, foram utilizados títulos da dívida federal para a capitalização dos bancos e, conseqüentemente, para seu saneamento. Parte destes recursos, portanto, não foi ainda recuperado pelo Banco Central, como indica a reportagem.
} 
Um dos principais resultados concretos do PROER foi, portanto, a diminuição daquilo que Roberto Lobato Corrêa $(1989,2006)$ denominou de "centros de gestão da atividade bancária". O caso dos três bancos supracitados é bastante representativo da perda do controle destas três cidades sobre importantes instituições bancárias. Repetiu-se, na esfera privada, o que ocorreria ao longo da década com os bancos estaduais: é esvaziada a capacidade de importantes regiões do território em comandar minimamente suas infra-estruturas e fluxos financeiros.

A perda das sedes das casas bancárias pelas capitais dos estados da Bahia, Paraná e Minas Gerais constitui-se numa manifestação do aumento da centralização do comando do território pela capital paulista. Não parece incorreto afirmar também, destarte, que desde a instalação do Plano Real o sistema bancário brasileiro vem ganhando eficiência econômica, mas perdendo capacidade de trabalhar em prol do território como um todo. Haveria recentemente no Brasil, assim, a predominância de lógicas "funcionais" em lugar das "territoriais", para usarmos os termos de John Friedmann e Clyde Weaver (1981) ${ }^{120}$.

Fica prejudicada, neste sentido, a possibilidade do sistema financeiro nacional trabalhar de forma mais "orgânica", fazendo chegar (ou permanecer) nas "áreas opacas" do território ao menos parte do comando da divisão bancária do trabalho.

\subsection{A face organizacional da aceleração dos fluxos financeiros: alguns aspectos nacionais e internacionais}

A competição pelos melhores pedaços do planeta passa a ser, no período da globalização, uma das estratégias das corporações transnacionais, sejam elas do ramo industrial, comercial, cultural ou financeiro. Essa competição que se gera entre elas aumenta a necessidade da velocidade e de segurança nos processos de

\footnotetext{
120 Para Friedmann e Weaver (1981:24), os vetores de planejamento "funcionais" são mais ligados aos atores transnacionais da economia, enquanto que "as forças territoriais derivam de nexos comuns de ordem social forjados pela história dentro de uma localidade concreta". Para os autores, ainda que seja necessário integrar os territórios à economia mundial, é necessário defender "a subordinação dos interesses funcionais, exógenos, aos de uma sociedade integrada territorialmente"(FRIEDMANN e WEAVER, 1981:308).
} 
comunicação "intra-firma", de busca de novos mercados e de inovações nos processos produtivos (ARROYO, 1995).

Essa aceleração chega também aos Estados nacionais. Através da implementação de uma série de políticas públicas, novos sistemas de movimento são desenvolvidos, assim como os de uso tradicional são aprimorados. Tecnologias de transmissão de dados tornam-se cada vez mais ubíquas, eficientes e baratas, para aumentar a produtividade e a velocidade dos fluxos (de imagens, ordens, bits) das empresas hegemônicas. Governos nacionais são convidados a alterar os conteúdos normativos de seus territórios, muitas vezes em detrimento dos arranjos "horizontais" existentes, construídos ao longo de décadas de esforço de planejamento.

Essa alteração na velocidade de transformação dos processos tecnológicos, políticos, e de transportes pode ser entendida como uma manifestação da "aceleração contemporânea", como propõe o geógrafo Milton Santos (1994, 1996). Com a "banalização da invenção", e com a rapidez com que são inventados e substituídos arranjos técnicos e políticos, os imperativos da fluidez e da competitividade são tidos como dados incontestáveis do presente. Na verdade, estes dados acabam por ajudar apenas um punhado de empresas hegemônicas, e não a totalidade dos atores econômicos (SANTOS, 1994:29-39).

As relações do sistema bancário e do sistema financeiro com o espaço geográfico não fogem deste quadro da "aceleração contemporânea". Pelo contrário, as empresas financeiras são em grande parte as responsáveis pelo arranjo atual da organização do mundo mais acelerado, um mundo com "dominância da esfera financeira", como bem frisou François Chesnais $(1997 ; 1998)^{121}$.

${ }^{121}$ Para Chesnais (1998:12) , a própria idéia de mundialização está intrinsecamente ligada às finanças, já que "a abertura, externa e interna, dos sistemas nacionais, anteriormente fechados e compartimentados, proporcionou a emergência de um espaço financeiro mundial". 
Dois são os exemplos que podemos descrever, para entendermos essa relação do processo de aceleração da história com o sistema financeiro brasileiro. Um diz respeito à conexão deste sistema com as redes globais de transmissão de dados financeiros entre países (através da chamada rede SWIFT), e outro tem relação direta com a modernização técnica e organizacional do sistema financeiro brasileiro (conseguida através da instalação do chamado Sistema de Pagamentos Brasileiro). Vejamos estes dois casos mais de perto.

9.3.1. A rede de mensageria Society for Worldwide Interbank Financial Telecommunication (SWIFT)

A Society for Worldwide Interbank Financial Telecommunication (SWIFT) é conhecida no jargão dos operadores do sistema financeiro como uma "rede de mensageria", como nos relatou em entrevista o engenheiro Gustavo Roxo. Através dela, é possível que os bancos (e demais agentes financeiros de alcance global) façam circular informações, dados e principalmente capitais (na forma de documentos criptografados ${ }^{122}$ ] de forma eficiente e segura.

Fundada na cidade de Bruxelas, no ano de 1973, a SWIFT auxiliava a realização das operações financeiras entre 15 países (basicamente os que compunham a Comunidade Econômica Européia), e tinha 239 bancos como clientes até então. Charles Goldfinger a definira, em meados dos anos 1980, como uma "rede interbancária pura, que assegura vinte e quatro horas por vinte e quatro horas uma ligação telemática entre 1.200 bancos em quarenta países"(GOLDFINGER, 1986:291).

\footnotetext{
122 A criptografia é a técnica que permite que os fluxos de mensagens e títulos financeiros sejam "codificados" pelo emissor do documento e "decodificados" apenas pelo receptor eleito do documento. Ela permite a segurança em quase 100\% dos casos de transferência de moedas na forma eletrônica. Como nota Robert Guttmann, foi em grande parte a criptografia que permitiu o desenvolvimento e a banalização do chamado "dinheiro eletrônico" nas transações financeiras e comerciais internacionais. Segundo o autor, "o surgimento do 'dinheiro eletrônico' (cybercash) (...) tornou-se possível graças às recentes descobertas no campo dos programas criptografados, garantindo a confidencialidade e segurança das transferências monetárias através da rede Internet"(GUTTMANN, 1998:71).
} 
Atualmente, segundo dados da própria empresa, não são mais apenas os Bancos seus principais clientes. Passam a se valer dessa rede outros atores financeiros, como corretores de valor (broker-dealers), gerentes de investimentos de grandes empresas e de fundos de pensão, câmaras de compensação de valores, entre outros. No ano de 2005, nada menos que 7.863 diferentes clientes (entre bancos e demais atores do mercado financeiro global) faziam uso desde sistema técnico, abrangendo 204 países do planeta (SWIFT, 2006).

A evolução da quantidade das mensagens, assim como dos países utilizadores dos serviços da empresa podem nos dar uma aproximação mais correta da aceleração que a SWIFT catalisa no espaço financeiro mundial.

Tabela 20: Evolução do Número de Mensagens, Clientes e Países Abrangidos pela SWIFT (1973-2005)

\begin{tabular}{|l|r|r|r|r|r|r|r|r|r|}
\hline & 1973 & 1977 & 1981 & 1985 & 1989 & 1993 & 1997 & 2001 & \multicolumn{1}{|l|}{2005} \\
\hline $\begin{array}{l}\text { Mensagens } \\
\text { (milhões) }\end{array}$ & - & 3,4 & 62,5 & 157,2 & 296,0 & 457,0 & 812,0 & $1.534,0$ & $2.518,0$ \\
\hline Clientes & 239 & 518 & 900 & 1.946 & 2.814 & 3.986 & 6.176 & 7.457 & 7.863 \\
\hline Países & 15 & 22 & 40 & 58 & 78 & 106 & 164 & 196 & 204 \\
\hline
\end{tabular}

Fonte: SWIFT. Swift History. 2006.

A capacidade de inclusão de novos espaços, de novos atores, e a magnitude dos fluxos transitados pela rede nestes últimos vinte e dois anos pareceu-nos bastante significativa do poder invasor que a aliança entre as técnicas informacionais e as finanças possuem contemporaneamente. A rede catalisou, portanto, uma enorme aceleração dos fluxos financeiros globais, e daí podermos considerá-la ao mesmo tempo uma conseqüência das necessidades dos atores financeiros globais, como uma causa da hegemonia atual destes atores sobre os fluxos financeiros ${ }^{123}$.

123 Segundo Carlos Alberto F. Silva, podemos considerar a rede SWIFT também como um dos elementos do espaço global que influenciou a automação bancária nos países, já que essa automação passa a ser condição sine qua non para a participação dos mercados financeiros nacionais nos fluxos da rede (SILVA, 1999:57) 
Um último dado do funcionamento da rede pareceu-nos essencial para entendermos essa aceleração dos fenômenos financeiros que a empresa permite. Com os avanços das técnicas da informação utilizadas pela SWIFT, processou-se ao longo dos anos também uma diminuição dos custos para a transmissão das mensagens dos atores financeiros. Uma mensagem que custava cerca de EU\$ 0,26 para ser transmitida/processada em 2001 custa hoje cerca de EU\$ 0,12, segundo dados do anuário da SWIFT (SWIFT, 2006). Essa diminuição dos custos proporcionada pela rede, portanto, acelera a utilização do sistema, aumenta a produtividade das empresas financeiras, e concede uma capacidade ainda maior para que ela organize os territórios e as economias nacionais dos países em função das vicissitudes dos grandes atores financeiros globais.

9.3.2. A modernização organizacional do sistema financeiro: o Sistema de Pagamentos Brasileiro e a Rede do Sistema Financeiro Nacional

Se a evolução da Society for Worldwide Interbank Financial Telecommunication (SWIFT) pode ser considerada como uma manifestação do poder das finanças na escala global, a instalação do novo Sistema de Pagamentos Brasileiro, no ano de 2002, é passível de ser entendida como a concretização deste poder no âmbito da formação socioespacial brasileira. O Sistema de Pagamentos Brasileiro (SPB) é considerado pelo Banco Central do Brasil como uma seqüência lógica das políticas públicas de "fortalecimento do sistema financeiro brasileiro", cujos principais pilares na década de 1990 foram o Programa de Incentivo à Redução do Estado na Atividade Bancária (PROES) e o Programa de Estímulo à Reestruturação e ao Fortalecimento do Sistema Financeiro Nacional (PROER). Se na década de 1990 o foco destas políticas públicas era "o fortalecimento das instituições financeiras", no início deste século a preocupação se volta para o funcionamento organizacional do sistema financeiro como um todo. Como demonstra documento do próprio Banco Central, 
“(...) Mais recentemente, o Banco Central do Brasil tem procurado atuar de forma mais intensiva também no sentido de promover o desenvolvimento dos sistemas de pagamentos de varejo, visando, sobretudo, ganhos de eficiência relacionados, por exemplo, com o maior uso de instrumentos eletrônicos de pagamento, com a melhor utilização das redes de máquinas de atendimento automático (ATM) e de transferências de crédito a partir do ponto de venda (PDV), bem como com a maior integração entre os pertinentes sistemas de compensação e de liquidação"(BANCO CENTRAL DO BRASIL, 2006).

Focado na busca do aproveitamento das novas possibilidades trazidas pelas tecnologias bancárias, no ano de 2002 o Banco Central introduz uma expressiva mudança na "rede do sistema financeiro nacional"(BANCO CENTRAL DO BRASIL:2006). Neste ano passa a funcionar o novo Sistema de Pagamentos Brasileiro (SPB).

O Sistema de Pagamentos Brasileiro pode ser considerado em primeiro lugar como um conjunto de normas para regular as transações diárias executadas pelos principais agentes financeiros instalados no território. Através desta nova forma técnico-organizacional, agentes financeiros privados, instituições públicas e semipúblicas fazem circular os principais fluxos de recursos financeiros no território. $\mathrm{Na}$ definição da Associação Nacional das Instituições do Mercado Aberto (ANDIMA), o SPB pode ser entendido como:

\footnotetext{
"o conjunto de procedimentos, regras, instrumentos e sistemas operacionais integrados, usados para transferir fundos do pagador para o recebedor e, com isso, encerrar uma obrigação de pagamento, interligando desta maneira o setor real da economia com as instituições financeiras e o Banco Central"(ANDIMA, 2002:2).
}

Segundo a análise de João Santana (2005), dois eram os principais problemas detectados no Sistema de Pagamentos Brasileiro (SPB), antes de sua renovação em 2002. Em primeiro lugar, as principais transações do Sistema não eram realizadas de forma instantânea. A rede de atores do sistema financeiro atuava de forma menos coesa, e no decorrer de todos os dias de negócios, havia sempre uma defasagem entre as "posiçõos devedoras" e as "posições credoras" dos agentes. Isto é, as transações de compra e venda de títulos, ativos e demais produtos 
financeiros eram realizadas sem a confirmação instantânea de que haveria saldo das "posições devedoras" para liquidar suas transações. A confirmação (ou não) da existência de saldos só seria realizada ao final do dia de transação (ou, em certos casos, até quatro ou cinco dias depois).

Sem esta instantaneidade, o chamado risco sistêmico ${ }^{124}$ da estrutura financeira brasileira era maior. Alguns atores da rede financeira nacional se valiam desta defasagem temporal para realizar negócios, sem ter necessariamente a contrapartida em recursos financeiros para tal realização. Quando do momento da liquidação da transação, o passivo da instituição poderia estar descoberto, e a transação não era liquidada. Essa quebra de contrato poderia gerar um efeito em cadeia, atingindo negativamente todas as empresas que estivessem de alguma forma ligadas à instituição "fraudadora". Daí o risco sistêmico. Como as empresas financeiras geralmente têm ramificações em praticamente todas as atividades econômicas (grandes bancos, pequenos bancos, indústrias, empresas de prestação de serviços, Estado, autarquias públicas, investidores, correntistas etc.), este risco influencia (direta ou indiretamente) praticamente toda a formação socioespacial brasileira.

Um segundo problema identificado, que justificava a modernização do Sistema de Pagamentos Brasileiro, se relacionava com a posição do Banco Central do Brasil em caso de problemas de insolvência nas negociações. Antes da criação do novo SPB, o "passivo" gerado por transações fraudulentas era assumido pelo Banco Central do Brasil. Dado o fato de ser o Banco Central (BC), ao fim e ao cabo, o "emprestador de última hora" no caso de grandes transações em descoberto, cabia

\footnotetext{
${ }^{124}$ O risco sistêmico, segundo a Associação Nacional das Instituições do Mercado Financeiro (ANDIMA), se define como o "risco que a incapacidade de uma instituição atender suas obrigações no vencimento implique a incapacidade de outras instituições de atenderem suas obrigações no vencimento"(ANDIMA, 2002:141). Com relação ainda ao Sistema de Pagamentos, podemos dizer que antes do ano de 2002 "Havia uma tendência de tornar os participantes negligentes em suas avaliações dos riscos dos sistemas e contrapartes, em virtude da garantia de liquidação sob a qual operava o sistema financeiro. As mensagens de liquidação financeira, enviadas pelas câmaras de liquidação privadas e pelo Banco Central, não eram processadas em tempo real, ou seja, as liquidações financeiras das operações com ativos financeiros ocorriam, muitas vezes, vários dias após a concretização do negócio. As operações eram liquidadas em lotes contra as contas-reserva, sem que os saldos fossem testados. $\mathrm{O} B C B$ só podia verificar a disponibilidade de saldo das contas Reserva Bancárias das instituições financeiras no final do dia, após o lançamento do último lote"(SANTANA, 2005:58).
} 
a ele socorrer a instituição inadimplente, pelos mesmos mecanismos descritos há pouco: uma grande operação que se mostrasse insolúvel dentro do sistema poderia gerar um efeito sistêmico de inadimplência, com conseqüências possivelmente desastrosas para todos os sistemas de ação econômicos (financeiros, industriais, comerciais, públicos etc.). Com a instalação do novo SPB, caem dramaticamente as possibilidades do Banco Central ter que injetar recursos no sistema, como ocorria com mais freqüência no passado (SANTANA, 2005).

O Sistema de Pagamentos Brasileiro (SPB), portanto, inaugura um novo "conjunto de procedimentos e regras" que, como vimos, vai conferir uma racionalidade maior aos fluxos de recursos, que circulam diariamente na Rede do Sistema Financeiro Nacional (RSFN). O que é a Rede do Sistema Financeiro Nacional (RSFN)? O organograma abaixo nos dá uma idéia de quais são os atores e as "câmaras" que compõem atualmente esta Rede:

Figura 1: Brasil: Rede do Sistema Financeiro Nacional (2006)

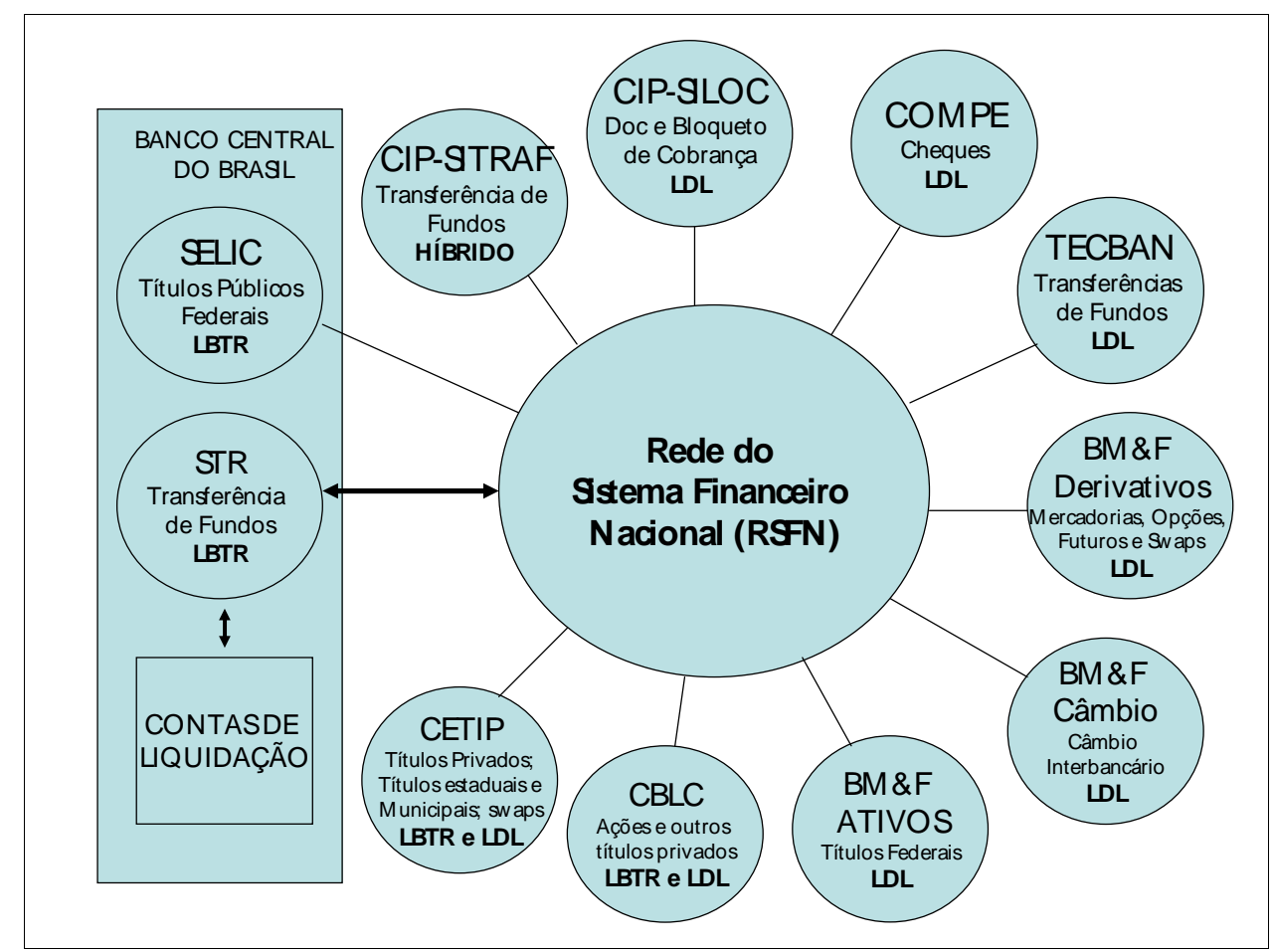

Fonte: Banco Central do Brasil. Sítio da Instituição (2006) 
A análise pormenorizada de toda a estrutura da Rede do Sistema Financeiro Nacional seria bastante demorada, e fugiria aos propósitos da tese ${ }^{125}$. Interessante para o entendimento da relação das finanças com o território é o destaque de cinco principais elementos desta Rede, que passam também a ser regulados pelo Sistema de Pagamentos Brasileiro. Estes elementos seriam: o Sistema Especial de Liquidação e Custódia (SELIC), a Central de Custódia e Liquidação Financeira de Títulos (CETIP), a Câmara Interbancária de Pagamentos (CIP-SITRAF), a Centralizadora de Compensação de Cheques e Outros Papéis (COMPE), e a câmara da Tecnologia Bancária S/A (TECBAN).

Os dois primeiros sistemas (SELIC e CETIP) lidam basicamente com compra $e$ venda de títulos (privados e públicos), ativos financeiros mais sofisticados (como os "derivativos") e ainda com negócios em moeda estrangeira. As três demais "câmaras" (CIP-SITRAF, COMPE e TECBAN) lidam com ativos monetários propriamente ditos, sejam moedas strictu sensu (papel-moeda ou moedas metálicas), cheques, cartões de crédito/débito (moeda eletrônica ${ }^{126}$ ) ou ainda "transferências de documento bancário" (os chamados "DOC's").

Conhecido popularmente na mídia brasileira como sendo o responsável pelo controle das taxas de juros praticadas pelos órgãos públicos, o Sistema Especial de Liquidação e Custódia (SELIC) pode ser definido como o "sistema responsável pela liquidação das operações envolvendo títulos públicos federais e alguns títulos

\footnotetext{
${ }^{125}$ Para uma análise pormenorizada de todas as câmaras, atores e operações financeiras do novo Sistema de Pagamentos Brasileiro (como indicados no organograma acima), ver relatórios da Associação Nacional das Instituições de Mercado Aberto - ANDIMA (2002) e do próprio Banco Central - BANCO CENTRAL DO BRASIL (2004).

126 Para Adenot e Albertini, a evolução das técnicas bancárias levou a um constante processo de "desmaterialização das moedas". Se antes elas dependiam de seu valor intrínseco (como é o caso das moedas metálicas), a cada dia elas passam ter seu valor vinculado muito mais a um conjunto de crenças (confiança) e regulamentações, do que de seu valor material. A introdução das técnicas da informação nos sistemas de ação bancários é mais um passo desta "desmaterialização", mas que não deixa de prescindir de uma série de outros objetos técnicos (computadores, redes de transmissão de dados) para sua operacionalidade ser garantida. (ADENOT e ALBERTINI, 1975:20-24). Segundo ainda Charles Goldfinger (1986:239 e ss.) esta evolução é própria do "jogo" entre forma e função que a moeda encerra. Na evolução do uso da moeda pelas sociedades, podemos perceber as seguintes "fases": a) a moeda em sua forma metálica cumpria (basicamente) a função de ativo real, pois tinha um valor em si; b) posteriormente, o papel-moeda passa a ser mais banalizado, e encarnava bem a função "unidade de conta"; c) é difundida a partir das décadas de 1950 e 1960 a moeda escritural, cuja forma cumpre em grande parte a função de "meio de pagamento", ou de "suporte a transações" entre agentes econômicos; d) hoje, com a tecnologia da informação, a estas formas é somada mais uma: a moeda eletrônica ou "moeda informacional".
} 
estaduais e municipais"(SANTANA, 2005:60) ${ }^{127}$. Segundo a Associação Nacional das Instituições do Mercado Aberto (ANDIMA), "apesar das suas origens estarem na criação do mercado aberto no Brasil na década de 60, o SELIC foi formalmente criado em 22 de outubro de 1979 para organizar a troca física de papéis da dívida e viabilizar uma alternativa à liquidação financeira por meio de cheques do Banco do Brasil, que implicava em risco elevado."(ANDIMA, 2006).

Com o avanço das tecnologias da informação, a liquidação passa a se dar cada vez mais de forma "desmaterializada" e daí podermos dizer que tanto o atual SELIC, quanto as demais câmaras de compensação/liquidação do Sistema de Pagamentos Brasileiro, serem um resultado da nova disponibilidade de meios técnicos (informacionais) no território, que permitem uma circulação dos fluxos da riqueza do país cada vez mais rápida e onipresente. As finanças, como mostra o caso do SELIC, passam a ser informação no atual período histórico.

Este circuito do SELIC ganha importância ímpar no atual período histórico, ao menos por quatro motivos:

a) os títulos que negocia se constituem no principal ônus que o Estado brasileiro tem que arcar, e representam atualmente quase que a totalidade da dívida pública brasileira;

b) estes títulos são também eminentemente "informacionais", de fácil transportabilidade; esta facilidade de mobilização geográfica dos títulos públicos parece ser um dos novos elementos que têm de ser levados em conta, para entendermos tanto a instabilidade econômica quanto a “instabilidade do território"(SILVEIRA, 2003b) brasileiro atual;

c) são detentores desses títulos principalmente os grandes atores do sistema financeiro, tanto nacionais quanto internacionais; isto é, são os bancos comerciais, de investimento, grandes fundos de pensão, e demais

127 Pelo SELIC são negociados, por exemplo, os títulos da dívida da União, no caso, os títulos do Tesouro Nacional $\left(\angle T N^{\prime} \mathrm{s}\right)$ e os títulos do Banco Central $\left(\angle B C^{\prime} \mathrm{s}\right)$. 
instituições financeiras que têm nos títulos públicos parte considerável de suas "carteiras de investimento"128;

d) dado o volume expressivo de títulos federais na composição dos haveres totais do território, as taxas de juros que são praticadas no circuito do SELIC vão interferir em todos os demais circuitos produtivos do território nacional. Isto é, as taxas de remuneração que o governo garantir para os compradores desses títulos servirão de base para os agentes econômicos instalados no território, para balizar a rentabilidade comparativa entre um investimento produtivo que ele possa realizar, ou a simples compra dos títulos do governo. Quanto mais altas as taxas de juros praticadas pelo Governo em seus títulos, portanto, maiores os investimentos dos atores econômicos nesses "papéis", e menores as quantidades de recursos carreadas para os circuitos geográficos industriais, comerciais etc. ${ }^{129}$

Se o SELIC cuida da custódia, transação e liquidação dos fluxos de títulos emitidos pelo Estado brasileiro, a Central de Custódia e Liquidação Financeira de Títulos (CETIP) realiza os mesmos procedimentos para o caso dos "títulos privados em geral"(SANTANA, 2005:71). Conforme definição de José Vicente Santana (2005:71), a CETIP “é uma câmara provedora de ambiente eletrônico para fechamento de negócios e leilões, e de registro e liquidação de operações”. Estes títulos são geralmente emitidos pelas empresas privadas, sendo conhecidos como "títulos de renda fixa privados". Estes servem tanto para a captação de recursos para investimentos (debêntures, $C D B^{\prime}$ s), ou ainda para realizar operações de

\footnotetext{
${ }^{128}$ Vale destacar que esses títulos públicos negociados nos circuitos do SELIC são importantes para o sistema financeiro não só por sua magnitude, mas também por uma de suas características próprias: tanto as LTN's quanto as LBC's são considerados "títulos sem risco" (riskless bonds). Significa dizer que, em tese, o Estado brasileiro (ao menos desde a última moratória declarada pelo Ministro Dílson Funaro, no ano de 1986) tem garantido rigorosamente o retorno do capital investido pelos atores financeiros nos seus títulos.

${ }_{129}$ Como nos lembra Fernando Costa (2000a), também em função do expressivo volume dos recursos movidos pelo Governo Federal (Tesouro) e seus sistemas de ação financeiros (Banco Central, Banco do Brasil, Caixa Econômica Federal), conferem a eles o atributo de "fazedores de mercado" ("market makers"). Para Costa, portanto, "Há uma hierarquia entre os agentes financeiros. Os market makers são os agentes líderes, com fontes de financiamento em fundos sociais, que determinam as taxas de juros de referência para empréstimos. Os líderes têm maior capacidade de delinear as tendências do mercado. Historicamente, os bancos públicos de maior porte sempre cumpriram esse papel, na economia brasileira. Cada qual em seu "nicho" (agricultura, habitação, infra-estrutura, desenvolvimento regional), os verdadeiros "fazedores do mercado" - bancos cujos comportamentos regulavam a competição inclusive no mercado de varejo - eram eles." (COSTA, 2000b)
} 
seguro contra os riscos de mercado (operações de hedge). Dentre os principais papéis que compõem estes fluxos e estoques de recursos, podemos destacar:

- Certificados de Depósito Bancário (CDB]

- Depósitos Interfinanceiros (DI)

- Letras de Câmbio (LC)

- Letras Hipotecárias (LH)

- Debêntures e demais commercial papers (BANCO CENTRAL DO BRASIL, 2006)

A grande maioria destes títulos também é emitida escrituralmente, isto é, existem apenas sob a forma de registros eletrônicos los títulos emitidos em papel são fisicamente custodiados por bancos autorizados). Conforme mostra o próprio sítio do Banco Central, são os seguintes atores do sistema financeiro que realizam grande parte de suas ações pelo CETIP:

- bancos comerciais, bancos múltiplos, caixas econômicas, bancos de investimento, bancos de desenvolvimento;

- sociedades corretoras de valores, sociedades distribuidoras de valores, sociedades corretoras de mercadorias e de contratos futuros;

- empresas de leasing, companhias de seguros;

- bolsas de valores, bolsas de mercadorias e futuros;

- investidores institucionais, pessoas jurídicas não financeiras, incluindo fundos de investimento e sociedades de previdência privada, investidores estrangeiros.

Toda esta estrutura da CETIP contava, no ano de 2004, com cerca de 4.800 participantes credenciados (BANCO CENTRAL DO BRASIL, 2006). Este número nos dá uma idéia da quantidade de atores que têm nesta "câmara" um instrumento privilegiado de consecução de suas estratégias econômicas.

Um terceiro componente do Sistema de Pagamentos Brasileiro, também essencial para o funcionamento da Rede do Sistema Financeiro Nacional é a Câmara Interbancária de Pagamento (CIP), criada pela Federação Brasileira de Associação de Bancos (FEBRABAN) como uma sociedade civil (sem fins lucrativos), "com o 
objetivo de criar e operacionalizar sistemas e procedimentos, além da compensação de transferência de fundos" (SANTANA, 2005:58).

Seu objetivo é o de disponibilizar junto ao mercado um "sistema eletrônico de recursos, com liquidação pelo valor apurado ao final do dia e dando certeza de liquidação em tempo real, atuando como contraparte garantidora dos pagamentos solicitados entre Instituições Financeiras" (SANTANA, op. cit.:69).

\begin{abstract}
A Câmara realiza este objetivo através do Sistema de Transferência de Recursos (SITRAF), sistema do qual participam somente as "instituições titulares de contas Reservas Bancárias" do Banco Central ${ }^{130}$; estes titulares são, por seu turno, os Bancos (comerciais, múltiplos, de investimento) e Caixas Econômicas, isto é, os grandes atores - públicos e privados - do sistema financeiro nacional. No ano de 2004, eram 119 instituições financeiras que participavam do SITRAF (BANCO CENTRAL DO BRASIL, 2004:15) ${ }^{131}$.
\end{abstract}

A segunda "câmara" que lida diariamente com moedas, e que se constitui também em parte essencial do Sistema de Pagamentos Brasileiro é a Centralizadora de Compensação de Cheques e Outros Papéis (COMPE). A COMPE é na verdade a câmara de compensação de cheques que são emitidos contra as instituições bancárias em todo o território nacional. Segundo o documento do Banco Central, tanto a COMPE, como suas câmaras "regionalizadas", poderiam ser assim definidas:

\footnotetext{
130 As chamadas contas "reservas bancárias" são mantidas pelos grandes atores financeiros do País junto ao Banco Central, para um monitoramento mais próximo das autoridades monetárias em relação a estes grandes atores. Segundo a definição de Biderman (2006:340), a reserva bancária é uma "conta mantida pelos bancos (bancos comerciais, bancos múltiplos, caixas econômicas e bancos de investimento) no Banco Central (BC), semelhante a uma conta-corrente por meio da qual é processada toda a movimentação financeira diária dos bancos, resultante das operações dos próprios bancos ou de seus clientes".

${ }^{131}$ No início de cada dia útil do mês, as instituições participantes fazem no SITRAF um depósito (o chamado "pré-depósito"), até as 7h30 da manhã; este valor é determinado pelo Banco Central, de acordo com uma média de operações de cada instituição que opera na Rede do Sistema Financeiro Nacional. Ao longo do dia, as operações realizadas pelas Instituições são cotejadas (e permitidas - ou não) de acordo com esses valores que cada instituição depositou no SITRAF. Segundo entrevista realizada com o engenheiro Gustavo Roxo, o SITRAF pode ser considerado como uma espécie de "guarda de trânsito para os fluxos de recursos entre os bancos". Caso haja alguma operação "descasada" sendo realizada (isto é, uma operação que não tenha o fundo correspondente para ser saldada), o Sistema acusa o problema, e impede que a operação seja realizada. Uma das grandes novidades organizacionais introduzidas, conseqüência das novas normas do Sistema de Pagamentos Brasileiro em 2002, foi justamente essa necessidade de que todas as grandes instituições financeiras depositassem pela manhã os recursos que utilizariam em suas transações ao longo do dia. Este procedimento é que diminuiu expressivamente o risco sistêmico do sistema financeiro brasileiro.
} 
"Cobrindo todo o território nacional, o sistema é composto, para fins de troca física de documentos, por uma câmara nacional, quinze câmaras regionais e dez câmaras locais. Em uma câmara local são trocados os cheques sacados contra as agências localizadas na praça por ela atendida. Na câmara regional, são trocados os cheques sacados contra agências bancárias localizadas nas praças por ela atendidas, vinculadas a uma praça centralizadora, sempre uma capital de Estado. Os cheques sacados contra bancos sem presença nas câmaras locais e regionais são trocados na câmara nacional, localizada em São Paulo, da qual todos os bancos obrigatoriamente participam, diretamente, ou por intermédio de representação"(BANCO CENTRAL DO BRASIL, 2004:17).

No ano de 2004, eram 141 instituições financeiras cadastradas na COMPE, sendo somente instituições bancárias as utilizadoras desta câmara. Os dados dos cheques apresentados em cada praça financeira com valor acima de $R \$$ 250.000,00 são imediatamente comunicados - via digital - para a Central de Processamento da COMPE (localizada em São Paulo/capital), para que sua liquidação eletrônica seja realizada. Também as trocas físicas destes cheques de grande valor são realizadas no mesmo dia da apresentação do cheque, seja qual for a praça financeira que ele tenha sido apresentado.

Já os cheques com valor menor que $R \$ 250.000,00$ los chamados "cheques abaixo"), são transmitidos para a Central de Processamento no dia seguinte de sua apresentação; o transporte físico deles é realizado também um dia após sua apresentação.

Por último, mas não menos importante, faz-se necessário descrever o funcionamento da Tecnologia Bancária S/A (TECBAN), já que através desta câmara é que a instalação de uma rede seletivamente difusa de "caixas eletrônicos" foi tornada possível no território (como veremos no capítulo 11). A bem da verdade, a TECBAN foi uma empresa criada em 1982, por iniciativa de bancos brasileiros, com o objetivo de desenvolver e consolidar a rede de auto-atendimento denominada "Banco 24 Horas" (SILVA, 1999:59). Esta rede de terminais é um exemplo concreto da capilaridade atual dos sistemas de objetos financeiros do 
território brasileiro, cujos pontos localizam-se principalmente nas grandes e médias cidades da Região Concentrada do território.

A rede dos terminais do "Banco 24 Horas", operada pela TECBAN conta atualmente com 47 instituições financeiras afiliadas, e com nada menos que 2.674 pontos de atendimento (quiosques ou terminais simples) espalhados pelo território. Cerca de 85 milhões de cartões têm acesso a essa rede de terminais da empresa, segundo dados do Banco Central (2004). Foi justamente em função desta topologia capilarizada, e também pela quantidade enorme de operações financeiras realizadas nesta rede (saques, depósitos, transferências de valores, pagamentos) que foi criada, no ano de 2001, uma "câmara de compensação" exclusiva da empresa, para a transferência e liquidação de valores realizadas através dela.

Estes são os principais circuitos pelos quais são movimentados, diariamente, parte significativa da riqueza financeira nacional. Um conjunto de sistemas de objetos (sedes de bancos, agências, caixas eletrônicos, redes de telecomunicações), mas também um conjunto de normas e de ações é que dão vida a estes circuitos, permitindo uma grande aceleração e um aumento da eficácia do uso financeiro do território brasileiro. Para termos uma idéia do número de transações envolvidas, e as quantidades de dinheiro mobilizadas em três das "câmaras" supracitadas, podemos observar a tabela abaixo:

Tabela 21: Brasil: Sistema de Compensação e de Liquidações - Operações Processadas (2005)

\begin{tabular}{|l|r|r|r|r|}
\hline & \multicolumn{2}{|c|}{ Quantidade de operações } & \multicolumn{2}{c|}{ Valor } \\
\hline & \multicolumn{1}{|c|}{ Milhões } & \multicolumn{1}{c|}{$\%$} & (R\$ milhões) & \multicolumn{1}{c|}{$\%$} \\
\hline $\begin{array}{l}\text { CIP } \\
\text { (SITRAF/SILOC) }\end{array}$ & 999 & 17,2 & 2.891 .955 & 50,8 \\
\hline COMPE & 1.965 & 34,5 & 1.101 .784 & 19,4 \\
\hline TECBAN & 52 & 0,9 & 2.813 & - \\
\hline Outros Sistemas & 2.685 & 47,0 & 1.693 .090 & 23.5 \\
\hline TOTAL & 5.700 & 100,0 & 5.686 .964 & 100,0 \\
\hline
\end{tabular}

Fonte: Elaboração própria a partir de Banco Central do Brasil. Diagnóstico do Sistema de Pagamentos de Varejo do Brasil (2005) 
A análise da tabela 21 revela ao menos três pontos fundamentais acerca do funcionamento da Rede do Sistema Financeiro Nacional. Em primeiro lugar, vale destacar que passa pelos circuitos da Rede uma quantidade vultosa de recursos. Divididos os $\mathrm{R} \$ 5.686$ trilhões que são movimentados anualmente pelo sistema, temos a quantia nada desprezível de cerca de $\mathrm{R} \$ 15$ trilhões diários de recursos, que circulam por esta "rede corporativa" do território brasileiro.

Em segundo lugar, vemos que a TECBAN, apesar da importância que possui para os pequenos correntistas (e para a população bancarizada de uma maneira geral), gera uma movimentação bem mais modesta, em comparação com as demais partes da Rede. Em termos concretos, sua participação significaria $\mathrm{R} \$$ 7,7 milhões por dia da riqueza financeira do país.

Por último, voltando nossa atenção para a movimentação realizada pela COMPE, vemos que, apesar de haver uma tendência generalizada para a transformação dos meios de pagamento de materiais para informacionais, os dados desta "câmara" mostram que o cheque é ainda uma forma bastante importante de realização de transações econômicas no território brasileiro.

Pareceu-nos necessário este detalhamento um pouco mais acurado do novo Sistema de Pagamentos Brasileiro pois todos os sistemas de ações e de objetos envolvidos são representativos deste período em que há um aumento do peso das finanças no uso do território brasileiro. São várias as conseqüências desta renovação da base técnica e organizacional do território para seu uso.

No que tange ao funcionamento do sistema bancário (e do sistema financeiro como um todo), o novo Sistema de Pagamentos Brasileiro possibilitou, em primeiro lugar, o surgimento de uma maior quantidade de "inovações financeiras", já que o Sistema proporciona maior rapidez e segurança para os fluxos de títulos la chamada "moeda escritural"), ordens e informações manipuladas diariamente. Um 
sistema informacional permite que moedas informacionais circulem com maior eficácia.

Já que o Sistema é também mais seguro para as transações, e menores são os custos envolvidos no transporte/custódia dos ativos financeiros, aumenta também a "liquidez" das operações realizadas a partir do novo SPB. Neste sentido é que podemos dizer que aumenta seu poder de influenciar o comportamento dos atores econômicos. Maior segurança e menores custos podem tanto atrair investimentos internacionais quanto drenar poupanças de outros setores de atividades desenvolvidas no território para o sistema financeiro. Não nos parece exagero, destarte, falar de um aumento da influência que o Sistema de Pagamentos engendrou recentemente nas atividades econômicas desenvolvidas no território.

O novo Sistema de Pagamentos Brasileiro tanto aumentou a velocidade dos fluxos financeiros no território, quanto permitiu que praticamente todo o território estivesse conectado com os fluxos e os estoques de títulos negociados pelo Sistema. Seja através das agências bancárias, de caixas eletrônicos, ou mesmo através da Internet, a segurança e a eficácia técnica do novo Sistema permite que grandes ou pequenos atores econômicos se utilizem desta nova rede montada. A partir de uma integração material do território, passamos também a uma eficaz integração organizacional, que permite a circulação veloz e segura das informações financeiras entre os principais atores que se utilizam do SPB. 


\section{CAPítULO 10. A Evolução Recente da Topologia Bancária e da "Geografia do Crédito"}

Após a análise dos novos conteúdos técnicos, organizacionais e normativos que foram acrescentados a partir do ano de 1994 no território brasileiro, parece ser possível passarmos para o entendimento de como essa modernização, despatrimonialização e a aceleração dos fixos e dos fluxos de nosso sistema bancário repercutiram no uso financeiro do território.

Por meio da nova base técnica e organizacional contemporânea, houve rearranjo expressivo da divisão bancária do trabalho no espaço brasileiro, repercutindo tanto no processo de concessão de créditos no território, quanto na topologia bancária.

No que diz respeito à concessão de crédito, num primeiro momento procuraremos analisar suas variações recentes na escala da formação socioespacial brasileira. Quais foram as regiões que aumentaram sua participação nos créditos concedidos pelo sistema bancário? E os depósitos no sistema bancário, quais as suas variações regionais? Quais os bancos que mais cresceram neste período da geografia financeira brasileira? Os nacionais privados, os estatais ou os estrangeiros?

Pareceu também importante verificar a evolução da concessão de crédito na escala local do território, e daí nossa preocupação em entender melhor a relação das finanças com algumas das dinâmicas urbanas atuais do espaço nacional. Quais os novos objetos técnicos que fazem parte do processo de "creditização do território"[SANTOS, 1993, 1996) na escala urbana? Quais os impactos do uso destes objetos para os diferentes atores econômicos (empresas, consumidores)? Que tipos de créditos foram tornados possíveis, dadas as atuais normas do sistema financeiro nacional?

Ao lado da questão da concessão de crédito, portanto, outro elemento se mostra essencial para o entendimento da relação atual do território com as finanças: a topologia bancária brasileira. A evolução recente da distribuição dos fixos geográficos bancários (Agências, Postos de Atendimento, Caixas Eletrônicos) 
mostra novidades no que diz respeito à acessibilidade da prestação dos serviços bancários. Também em função do aparecimento de novos objetos técnicos que aumentam o alcance social e espacial destes serviços, podemos dizer que foi incrementada sensivelmente a capilaridade da concessão de crédito no território brasileiro. No limite, podemos falar de uma hipercapilaridade das finanças.

\subsection{A nova geografia dos passivos e dos ativos regionais}

Há tempos a geografia humana tem como uma de suas principais preocupações o que poderíamos chamar da questão das desigualdades regionais. Halford Mackinder $(1919,1942)$ acreditava que essas diferenças, quando muito acentuadas, eram causas freqüentes de guerras, ou conflitos entre os povos. Edward Ullman (1980:80-96), por seu turno, mostrava que o problema da "concentração do desenvolvimento" era um dado universal da organização espacial dos países, fossem estes "desenvolvidos" ou subdesenvolvidos".

O que pode ser dito da relação entre as desigualdades regionais e o sistema bancário?

O economista sueco Gunnar Myrdal, em seu clássico Teoria Econômica e Regióes Desenvolvidas, já asseverava que "o sistema bancário quando não controlado para operar de maneira diferente, tende a transformar-se em instrumento que drena as poupanças das regiões mais pobres para as regiões mais ricas e mais progressistas, onde a remuneração do capital é alta e segura"(1956, 1965:54).

Raciocínio semelhante desenvolve ainda o geógrafo Jean Labasse, para quem "as redes bancárias trabalham a favor das metrópoles"(1976:10) nos países em que estão instaladas, e se deixadas sob o jugo das chamadas "forças de mercado", a tendência é que as desigualdades regionais aumentem, e não o contrário.

Uma das formas de visualizar a relação entre o sistema bancário e as desigualdades regionais dos países tem relação com a concessão de créditos, e com a realização de depósitos em cada área bancária. Através da análise desta distribuição, assim como dos atores responsáveis pela manipulação dos mesmos, é possível 
estabelecer o que Jean Labasse (1955) chamou de "geografia do crédito"132. Esta, por sua vez, nos auxilia a entender quais são as regiões mais dinâmicas em relação ao processo de circulação do capital. Permite também assinalar quais os atores financeiros que se inserem (ou não) mais ativamente na divisão bancária do trabalho, em cada período histórico. Como mostra ainda Ary Minella (2001:53), "o controle do fluxos de capitais", "(...) constitui o elemento fundamental do poder das instituições financeiras atualmente".

A concessão de recursos creditícios no território, entre os anos de 1996 e 2004, mostrou uma evolução seletiva, tendo alguns atores se tornado mais importantes que outros.

Tabela 22: Brasil: Evolução da Participação das Instituições Bancárias nas Operações de Crédito Concedidas no Território (1996-2004)

\begin{tabular}{|c|c|c|c|c|c|c|c|c|c|c|}
\hline & \multicolumn{2}{|c|}{1996} & \multicolumn{2}{|c|}{1998} & \multicolumn{2}{|c|}{2000} & \multicolumn{2}{|c|}{2002} & \multicolumn{2}{|c|}{2004} \\
\hline & $\begin{array}{c}\mathrm{R} \$ \\
\text { bilhões }\end{array}$ & $\%$ & $\begin{array}{c}\mathrm{R} \$ \\
\text { bilhões }\end{array}$ & $\%$ & $\begin{array}{c}\mathrm{R} \$ \\
\text { bilhões }\end{array}$ & $\%$ & $\begin{array}{c}\mathrm{R} \$ \\
\text { bilhões }\end{array}$ & $\%$ & $\begin{array}{c}\mathrm{R} \$ \\
\text { billhões }\end{array}$ & $\%$ \\
\hline $\begin{array}{l}\text { Bancos } \\
\text { Públicos (e } \\
\text { Caixas } \\
\text { Estaduais) }\end{array}$ & 45,1 & 23,5 & 16,5 & 8,9 & 11,7 & 5,1 & 12,4 & 4,8 & 15,1 & 4,4 \\
\hline $\begin{array}{l}\text { Banco do } \\
\text { Brasil }\end{array}$ & 20,4 & 10,6 & 22,5 & 12,1 & 25,0 & 11,0 & 41,9 & 16,2 & 66,2 & 19,4 \\
\hline $\begin{array}{l}\text { Caixa } \\
\text { Econômica } \\
\text { Federal }\end{array}$ & 46,1 & 24,0 & 60,3 & 32,3 & 52,5 & 23,0 & 19,7 & 7,6 & 25,6 & 7,5 \\
\hline $\begin{array}{l}\text { Bancos } \\
\text { Privados } \\
\text { Nacionais }\end{array}$ & 61,2 & 31,9 & 57,8 & 31,0 & 78,8 & 34,5 & 103,0 & 39,7 & 141,3 & 41,3 \\
\hline $\begin{array}{l}\text { Bancos com } \\
\text { controle } \\
\text { estrangeiro }\end{array}$ & 18,3 & 9,5 & 27,8 & 14,9 & 57,4 & 25,2 & 77,6 & 29,9 & 85,9 & 25,1 \\
\hline $\begin{array}{l}\text { Cooperativa } \\
\text { s de Crédito }\end{array}$ & 1,0 & 0,5 & 1,7 & 0,9 & 2,8 & 1,2 & 4,6 & 1,8 & 7,9 & 2,3 \\
\hline $\begin{array}{l}\text { TOTAIS } \\
\text { (BRASIL) }\end{array}$ & 192,1 & 100 & 186,6 & 100 & 228,3 & 100 & 259,2 & 100 & 342,0 & 100 \\
\hline
\end{tabular}

Fonte: Elaboração própria a partir de Banco Central do Brasil - Cosif (2006)

132 A relação entre concessão de créditos e realização de depósitos é um dos principais pilares do funcionamento do sistema bancário, e constitui o centro do que se convencionou chamar de "intermediação financeira". Para Edward Reed e Edward Gill, "no sistema bancário, o volume de depósitos depende principalmente do volume de crédito oferecido pelos bancos na forma de empréstimos e investimentos"(REED e GILL, 1994:170). 
A tabela 22 parece mostrar com bastante acuidade parte dos resultados do processo de privatização dos bancos oficiais brasileiros. Os bancos públicos estaduais (ou regionais) são as instituições financeiras que mais perdem participação na concessão de créditos no território. De cerca de $\mathrm{R} \$ 45,1$ bilhões de créditos concedidos por estes atores (em 1996), passam a emprestar $R \$ 15,1$ bilhões no ano de 2004 (de 23,5\% dos empréstimos, passam a conceder apenas $4,4 \%)$.

Chama-nos a atenção ainda a perda de importância da Caixa Econômica Federal (CEF) neste cenário. Se no ano de 1996 ela era responsável pela concessão de $24 \%$ dos totais de crédito no território ( $\mathrm{R} \$ 46,1$ bilhões), passa a responder por apenas 7,5\% dos totais ( $R \$ 25,6$ bilhões) no ano de 2004 .

Nesta divisão do trabalho em processo de consolidação, os bancos privados nacionais aumentam sua influência. De $31,9 \%$ dos totais dos créditos que concediam ( $R$ \$ 61,2 bi em 1996), passam a realizar 41,3\% dos totais nacionais (em 2004, R\$ 141,3 bi), representando um crescimento de $131 \%$. Nota-se que estas instituições foram, portanto, privilegiadas com o arranjo atual da geografia do crédito brasileira.

Por fim, mas não menos importante, houve um tipo de instituição que teve incremento de participação ainda maior, no conjunto dos atores que irrigam o território com créditos no período atual: as instituições financeiras com controle estrangeiro. Estas vêem sua participação na concessão de créditos crescer em nada menos que 369\%, no período iniciado após a instalação do Plano Real (19962004). De um total de $9,5 \%$ ( $R \$ 18,3$ bilhões) em 1996, esses bancos passam a emprestar 25,1\% dos totais, o que equivalia a $R$ \$ 85,9 bilhões, em 2004.

O comportamento dos depósitos realizados no sistema bancário brasileiro foi também semelhante ao dos créditos. 
Tabela 23: Brasil: Evolução da Participação das Instituições Bancárias nas Operações de Depósito Realizadas no Território [1996-2004)

\begin{tabular}{|c|c|c|c|c|c|c|c|c|c|c|}
\hline & \multicolumn{2}{|c|}{1996} & \multicolumn{2}{|c|}{1998} & \multicolumn{2}{|c|}{2000} & \multicolumn{2}{|c|}{2002} & \multicolumn{2}{|c|}{2004} \\
\hline & $\begin{array}{c}\mathrm{R} \$ \\
\text { bilhões }\end{array}$ & $\%$ & $\begin{array}{c}\mathrm{R} \$ \\
\text { bilhões }\end{array}$ & $\%$ & $\begin{array}{c}\mathrm{R} \$ \\
\text { billhões }\end{array}$ & $\%$ & $\begin{array}{c}\mathrm{R} \$ \\
\text { billhões }\end{array}$ & $\%$ & $\begin{array}{c}\mathrm{R} \$ \\
\text { billhões }\end{array}$ & $\%$ \\
\hline $\begin{array}{l}\text { Bancos } \\
\text { Públicos (e } \\
\text { Caixas } \\
\text { Estaduais) }\end{array}$ & 49,7 & 21,5 & 39,0 & 13,3 & 23,9 & 7,4 & 33,6 & 7,4 & 38,5 & 6,6 \\
\hline $\begin{array}{l}\text { Banco do } \\
\text { Brasil }\end{array}$ & 33,6 & 14,5 & 51,2 & 17,4 & 55,4 & 17,1 & 80,4 & 17,7 & 100,4 & 17,1 \\
\hline $\begin{array}{l}\text { Caixa } \\
\text { Econômica } \\
\text { Federal }\end{array}$ & 53,5 & 23,1 & 60,4 & 20,5 & 63,4 & 19,5 & 76,8 & 16,9 & 91,8 & 15,6 \\
\hline $\begin{array}{l}\text { Bancos } \\
\text { Privados } \\
\text { Nacionais }\end{array}$ & 77,2 & 33,4 & 97,3 & 33,1 & 110,3 & 33,9 & 166,0 & 36,6 & 231,4 & 39,4 \\
\hline $\begin{array}{l}\text { Bancos com } \\
\text { controle } \\
\text { estrangeiro }\end{array}$ & 16,6 & 7,2 & 44,6 & 15,1 & 68,7 & 21,1 & 89,9 & 19,8 & 117,0 & 19,9 \\
\hline $\begin{array}{l}\text { Cooperativas } \\
\text { de Crédito }\end{array}$ & 0,7 & 0,3 & 1,7 & 0,6 & 3,3 & 1,0 & 6,9 & 1,5 & 8,2 & 1,4 \\
\hline $\begin{array}{l}\text { TOTAIS } \\
\text { (BRASIL) }\end{array}$ & 231,4 & 100 & 294,3 & 100 & 325,1 & 100 & 453,7 & 100 & 587,2 & 100 \\
\hline
\end{tabular}

Fonte: Elaboração própria a partir de Banco Central do Brasil - Cosif (2006)

Podemos destacar um dado mais geral, relacionado tanto ao fenômeno dos depósitos, quanto dos créditos realizados pelo sistema: houve expressivo crescimento das quantias envolvidas nas operações financeiras realizadas. Se tomarmos o exemplo dos depósitos, vemos que foram depositados R $\$ 231,4$ bilhões no ano de 1996, passando para um total de R\$587,2 bilhões em 2004. Um aumento de cerca de 154\%, para um período de 8 anos; este quadro reflete bem o aumento do poder do sistema financeiro brasileiro em sua capacidade de drenagem de recursos do território.

O que talvez seja importante ainda atentarmos é o crescimento diferencial ocorrido, em termos do controle dos estoques de depósitos. Assim como na evolução da variável "crédito", há instituições que perdem posição relativa no sistema financeiro nacional; assim como há instituições cuja importância cresce, e ainda algumas cuja importância cresce muito. 
O fenômeno que mais nos chama a atenção na análise da tabela 23 é a diminuição de importância dos bancos públicos ${ }^{133}$ na drenagem de recursos do território, tanto em termos absolutos, quanto relativos. De um total de $\mathrm{R} \$ 49,7$ bilhões (21,5\% dos totais) que estes atores recebiam em depósitos no ano de 1996, passam a controlar apenas $\mathrm{R} \$ 38,5$ bilhões $(6,6 \%$ dos totais), no ano de 2004 . Uma perda expressiva para um segmento do sistema financeiro que, historicamente, foi o que implementou as principais políticas de desenvolvimento regional do país, como vimos nos capítulos 4 e 7 . Esta diminuição é ainda mais preocupante pois, a priori, as instituições financeiras oficiais trabalham com a perspectiva da descentralização dos recursos no território, ao contrário das privadas.

A principal causa desta diminuição da importância dos fluxos públicos no sistema bancário foi a privatização dos bancos públicos estaduais. Com a profunda alteração na estrutura de propriedade do sistema financeiro (que culminou tanto na privatização, como na desnacionalização de parte do sistema), houve conseqüentemente repercussões sensíveis também no controle dos ativos financeiros do território.

O segundo principal ator prejudicado na evolução recente do sistema financeiro é também público: a Caixa Econômica Federal perde parte considerável de sua participação no sistema. Apesar de se manter ainda como a maior instituição recebedora de depósitos em termos individuais, passa de um total de $23,1 \%$ dos depósitos em 1996 realizados (com $\mathrm{R} \$ 53,5$ bilhões recebidos) para apenas $15,6 \%$ em 2004 (R\$ 91,8 bilhões).

Se pensarmos nas instituições que aumentaram sua participação no total dos depósitos, vale a pena destacar que as Cooperativas de Crédito tiveram um crescimento expressivo lapesar de representarem apenas 1,4\% dos totais

\footnotetext{
${ }^{133}$ Nas tabelas que seguem, além dos bancos estaduais, estão contemplados também as Caixas Econômicas de posse dos governos estaduais, assim como os bancos federais regionais (Basa e Banco do Nordeste do Brasil BNB).
} 
movimentados). Aumentaram ainda no período os depósitos no Banco do Brasil, que de $14,5 \%$ passou a controlar $17,1 \%$ dos totais. Já os depósitos realizados na rede de bancos privados nacionais também foram incrementados, e de 33,4\% dos totais passaram a controlar 39,4\% dos depósitos, no mesmo período.

O expressivo crescimento da participação das instituições financeiras com controle estrangeiro, porém, parece ser a tônica do período recente. A bem da verdade, esta realidade já fora destacada por estudiosos do assunto (PUGA, 1999; CALDERÓN e CASILDA, 2000; CARVALHO, STUDART e ALVES Jr., 2002; entre outros). O que importa destacar é que o "controle dessas instituições sobre o volume e o fluxo de capitais (...) afeta o conjunto da economia e cria constrangimentos aos processos decisórios de empresas e governos" (MINELLA, 2001:69]. Neste sentido, ganha significado expressivo esta mudança na geografia do crédito que analisamos nesta parte da tese.

No que tange aos atores estrangeiros, vemos que de um total de apenas $R \$ 16,6$ bilhões, os bancos deste tipo passam a comandar nada menos que $\mathrm{R} \$ 117$ bilhões em depósitos, no período de 1996 a 2004 . Em termos percentuais, os números são ainda mais significativos: de um total de apenas 7,2\% dos depósitos realizados em território brasileiro, os bancos estrangeiros passam a ser responsáveis por quase $20 \%$ dos mesmos $(19,9 \%)$. Há, portanto, um crescimento de $604,8 \%$ da desnacionalização do controle dos depósitos.

Esta é, em linhas gerais, a nova realidade da propriedade dos estoques de depósitos e dos fluxos de concessão de crédito do território brasileiro. $O$ levantamento, destarte, nos permitiu entender mais de perto a evolução recente do comando da "geografia do crédito" brasileira. Isto é, nos aproximamos um pouco mais do entendimento da nova divisão bancária do trabalho em instalação no território. O que pode ser dito - pensando nas mesmas variáveis - em termos de sua distribuição regional? Isto é, se houve instituições privilegiadas com o 
processo, houve também "regiões ganhadoras"- para usar os termos de Georges Benko e Alain Lipietz (1994)?

Assim como pudemos analisar para o período de 1945-65, pareceu-nos necessário pensar de forma atualizada na "drenagem e emprego de capitais móveis"(LABASSE, 1955:58) do território brasileiro, identificando a evolução recente dos "ativos" e dos "passivos regionais".

Tabela 24: Brasil: Evolução dos Ativos Regionais (Depósitos Bancários) no Território (em \%) (1997-2004)

\begin{tabular}{|l|r|r|r|r|r|r|r|r|}
\hline & $\mathbf{1 9 9 7}$ & $\mathbf{1 9 9 8}$ & $\mathbf{1 9 9 9}$ & $\mathbf{2 0 0 0}$ & $\mathbf{2 0 0 1}$ & $\mathbf{2 0 0 2}$ & $\mathbf{2 0 0 3}$ & $\mathbf{2 0 0 4}$ \\
\hline Região Norte & 1,2 & 1,3 & 1,5 & 1,5 & 1,4 & 1,6 & 1,3 & 1,3 \\
\hline Região Nordeste & 7,6 & 7,0 & 7,3 & 7,2 & 7,1 & 6,9 & 6,1 & 6,3 \\
\hline Região Sudeste & 71,3 & 68,5 & 69,5 & 69,2 & 67,2 & 64,5 & 65,9 & 68,9 \\
\hline Região Sul & 10,0 & 12,2 & 10,6 & 10,0 & 10,2 & 10,7 & 10,0 & 10,2 \\
\hline $\begin{array}{l}\text { Região Centro- } \\
\text { Oeste }\end{array}$ & 9,9 & 11,1 & 11,2 & 12,1 & 14,2 & 16,5 & 16,7 & 13,6 \\
\hline $\begin{array}{l}\text { Região } \\
\text { Concentrada }\end{array}$ & 81,3 & 80,7 & 80,1 & 79,2 & 77,4 & 75,2 & 75,9 & 79,1 \\
\hline BRASIL & 100,0 & 100,0 & 100,0 & 100,0 & 100,0 & 100,0 & 100,0 & 100,0 \\
\hline
\end{tabular}

Fonte: Banco Central. Diretoria de Normas e Organização do Sistema Financeiro. Estatística Bancária. (2006)

Pensando sobre a evolução dos depósitos, vemos que a região do país que mais cresce em termos relativos é o Centro-Oeste: dos $9,9 \%$ que representavam dos totais drenados do território brasileiro (1997), passam a receber $13,6 \%$ no ano de 2004. Já as regiões Norte e Sul demonstram pouca alteração em sua participação: a primeira responde por pouco mais de $1 \%$ dos depósitos entre os anos selecionados, enquanto a segunda cerca de $10 \%$.

O Nordeste perde uma parcela pequena de sua participação: de $7,6 \%$, passa a receber $6,3 \%$ dos totais nacionais. Por fim, o Sudeste é também uma região de declínio relativo da captação de depósitos: dos 71,3\% que recolhiam em 1997, passam a realizar apenas $68,9 \%$ dos totais. Proporção semelhante encontramos na evolução dos depósitos realizados no âmbito da Região Concentrada do país: de $81,3 \%$ dos totais nacionais, passa a captar $79,1 \%$; uma modesta diminuição de $2,2 \%$. 
No que diz respeito à evolução dos créditos (isto é, os passivos regionais), há tanto tendências semelhantes, como processos que parecem se distinguir do fenômeno de captação de depósitos.

Tabela 25: Brasil: Evolução dos Passivos Regionais (Créditos Bancários) no Território (em \%) (1997-2004)

\begin{tabular}{|l|r|r|r|r|r|r|r|r|}
\hline & $\mathbf{1 9 9 7}$ & $\mathbf{1 9 9 8}$ & $\mathbf{1 9 9 9}$ & $\mathbf{2 0 0 0}$ & $\mathbf{2 0 0 1}$ & $\mathbf{2 0 0 2}$ & $\mathbf{2 0 0 3}$ & $\mathbf{2 0 0 4}$ \\
\hline Região Norte & 1,9 & 1,9 & 1,5 & 1,4 & 1,2 & 1,1 & 1,4 & 1,5 \\
\hline $\begin{array}{l}\text { Região } \\
\text { Nordeste }\end{array}$ & 13,6 & 9,6 & 9,0 & 8,2 & 5,9 & 6,0 & 6,2 & 6,5 \\
\hline Região Sudeste & 59,5 & 63,0 & 64,2 & 65,5 & 72,2 & 72,9 & 70,9 & 69,0 \\
\hline Região Sul & 12,7 & 13,1 & 12,6 & 12,2 & 11,2 & 11,7 & 12,8 & 13,7 \\
\hline $\begin{array}{l}\text { Região } \\
\text { Centro-Oeste }\end{array}$ & 12,3 & 12,5 & 12,8 & 12,7 & 9,6 & 8,2 & 8,7 & 9,3 \\
\hline $\begin{array}{l}\text { Região } \\
\text { Concentrada }\end{array}$ & 72,2 & 76,1 & 76,8 & 77,7 & 83,4 & 84,6 & 83,7 & 82,7 \\
\hline BRASIL & 100,0 & 100,0 & 100,0 & 100,0 & 100,0 & 100,0 & 100,0 & 100,0 \\
\hline
\end{tabular}

Fonte: Elaboração Própria a partir de Banco Central. Diretoria de Normas e Organização do Sistema Financeiro. Estatística Bancária. (2006)

Uma análise mais aproximada dos dados da tabela 25 nos permite dividir as regiões brasileiras em dois principais tipos. Num primeiro grupo, poderíamos agrupar as regiões que perdem posição relativa em relação à concessão de créditos. Estariam entre estas a Região Norte, que passa a conceder apenas 1,5\% dos créditos nacionais (em 2004), em comparação aos 1,9\% que realizava (em 1997). Também a Região Centro-Oeste conhece evolução semelhante, já que movimentava $12,3 \%$ dos créditos totais realizados no território (1997), e passa a conceder apenas $9,3 \%$ dos totais.

Se o Norte e o Centro-Oeste perdem pouca posição relativa, o mesmo não pode ser dito da região Nordeste do país, a principal "região perdedora", em termos de passivos regionais do território. Dos $13,6 \%$ dos créditos que a região concedia em 1997, passa a movimentar menos que a metade destes valores, passando a movimentar apenas $6,5 \%$ dos créditos totais do país. 
Mas há também regiões que ganham posições relativas, no cenário da concessão de créditos pelo sistema bancário nacional. A Região Sul passa de um índice de $12,7 \%$ dos créditos concedidos, para cerca e $13,7 \%$ dos totais nacionais. A Região Sudeste é também uma "região ganhadora", ao menos no que tange a esta variável "concessão de créditos" na evolução recente do sistema bancário: dos $59,5 \%$ que recebia (1997), passa a conceder praticamente $10 \%$ a mais no período, já que polarizava (no ano de 2004) 69\% dos totais.

O mesmo movimento se registra para a Região Concentrada: dos $72,2 \%$ que recebia de créditos, passa a contar com nada menos que $82,7 \%$ dos totais. Ocorre um reforço, portanto, da densidade financeira desta parcela do território brasileiro, em relação a esta variável específica.

Este seria, pode-se dizer, um quadro regionalizado da intermediação financeira realizada no território brasileiro, após a consecução do Plano Real. Se pensarmos nas alterações ocorridas no sistema de ação financeiro do território, talvez possamos chegar a algumas explicações para esta nova geografia da intermediação financeira. No caso da Região Nordeste, há ao menos duas alterações de monta que permitem entender melhor essa diminuição das quantidades dos recursos financeiros movimentados na Região:

a) a privatização dos bancos públicos estaduais (através do PROES)

Conforme vimos no Capítulo 9, todos os bancos públicos estaduais do Nordeste sofreram algum tipo de alteração patrimonial. Num período de menos de sete anos, são fechados, privatizados ou federalizados todos os nove bancos estaduais da Região, assim como as demais instituições financeiras ligadas aos bancos estaduais (empresas de leasing, bancos de desenvolvimento, distribuidoras de títulos etc.).

Aqueles bancos na Região Nordeste que foram vendidos à iniciativa privada passaram também por uma reorganização funcional interna, que culminaram com o deslocamento da burocracia de comando do banco para as cidades do Sudeste do 
país, em particular para a cidade de São Paulo. Foi o caso do Banco do Estado de Pernambuco (BANDEPE) e do PARAIBAN (Paraíba), ambos adquiridos pelo ABN/Amro (com sede em São Paulo). Foi também o que ocorreu com o Banco do Estado da Bahia (BANEB), Banco do Estado do Maranhão (BEM) e Banco do Estado do Ceará (BEC), todos adquiridos pelo Bradesco (com sede em Osasco, na Região Metropolitana de São Paulo).

Com a transferência das sedes dessas organizações para a cidade de São Paulo, a Região vê bastante prejudicada a possibilidade de comando autônomo da vida financeira de seus Estados. Diminui no Nordeste o "setor quaternário" de sua economia, isto é, aquelas atividades de serviços bastante sofisticadas, desenvolvidas em função da presença de centros e sedes das empresas (consultorias, serviços especializados etc.) nos lugares.

Se historicamente esta parcela do território vem se constituindo muito mais numa "região do fazer" do que numa "região do mandar", para usar a terminologia do geógrafo Milton Santos (1994a:114) ${ }^{134}$, a evolução recente da divisão financeira do trabalho parece ter acentuado essa seletividade. A perda de posição relativa em relação aos créditos e depósitos é, com efeito, um reflexo destes novos conteúdos da região.

b) a reorganização no âmbito do PROER

Essa perda de posição relativa está relacionada ainda com os resultados concretos do Programa de Estímulo à Reestruturação e ao Fortalecimento do Sistema Financeiro Nacional (PROER). Através do PROER, como vimos, houve a liquidação/venda do Banco Econômico, com sede na capital do Estado da Bahia (Salvador). Esta é, portanto, mais uma importante instituição que deixa de ter sede na região (já que o Banco pertence atualmente ao Bradesco ${ }^{135}$ ).

\footnotetext{
${ }^{134}$ Segundo a definição do autor, "naquelas regiões onde o sistema de objetos e o sistema de ações são mais densos, aí está o centro do poder. Naquelas outras áreas onde o sistema de objetos e o sistema de ações é menos complexo e menos inteligente, aí está a sede da dependência, da incapacidade de dirigir a si mesmo"(SANTOS, 1994a:114).

${ }_{135}$ Conforme mencionado no item 9.2, a perda do estado da Bahia sobre o comando do Banco Econômico se dá através das seguintes operações: após a intervenção federal no Banco (iniciada com o PROER, em 1995), o espólio do Banco Econômico é comprado pelo Banco Excel (no ano de 1997). O Banco Excel/Econômico, por sua vez, é vendido para o espanhol Banco Bilbao e Viscaya (BBV), em 1998. Por fim, no ano de 2003, esta nova instituição, unificada em torno do BBV, é adquirida pelo Banco Bradesco.
} 


\subsection{A nova topologia bancária: das agências à hipercapilaridade das finanças}

Este conjunto de transformações na organização do sistema bancário brasileiro não se restringiu apenas às normas, às técnicas e à divisão financeira do trabalho no território. O avanço da pesquisa mostrou que houve mudanças bastante significativas no uso recente do território brasileiro também no que tange a sua “topologia bancária" (SANTOS e SILVEIRA, 2001:189 e ss.).

Um primeiro dado novo desta topologia diz respeito aos fixos geográficos que servem para a organização bancária do território: de um padrão fundado eminentemente nas agências bancárias, o sistema bancário passa a utilizar com mais freqüência outras formas geográficas para a prestação de seus serviços. Como veremos nos Capítulos 10 e 11, é aprofundada a utilização dos Postos de Atendimento Bancário (PAB's) e dos "caixas automáticos" (ou "ATM's"); mas são também criadas novas formas de acessibilidade aos serviços bancários, dadas pela expansão do uso de Correspondentes Bancários e de novos "canais eletrônicos" no território ${ }^{136}$.

No que diz respeito à distribuição desses fixos geográficos, vemos que no período ocorre uma diminuição do número de agências, principalmente nas áreas menos dinâmicas do território. Essa diminuição ocorre seletivamente, e se dá sobejamente naquelas parcelas que comporiam uma "geografia letárgica" (SILVEIRA, 1999) da divisão territorial do trabalho.

Concomitantemente a essa diminuição da topologia "tradicional", há um aumento da acessibilidade ao crédito permitida por uma nova qualidade da rede bancária, uma rede mais informacional e mais capilarizada. Talvez o exemplo mais expressivo desta maior acessibilidade seja a proliferação dos cartóes de crédito. O que importa destacar é que novas formas geográficas, contemporâneas ao atual período

\footnotetext{
${ }^{136}$ Na década de 1970, como vimos para o caso da Caixa Econômica do Estado de São Paulo, já se inicia um processo de racionalização da rede-suporte do sistema bancário nacional, através do uso dos Postos de Atendimento Bancário em sua constituição. Esta difusão persiste nas décadas de 1980 e, em meados dos anos 1990 este processo parece ter chegado a uma inflexão. As agências e os PAB's (que analisaremos no item a seguir) perdem importância relativa nas redes bancárias, dando surgimento a uma nova topologia no uso financeiro do território.
} 
histórico, são incorporadas ao território, alterando sensivelmente a qualidade e o alcance da topologia bancária brasileira.

\subsection{A evolução recente da topologia bancária "tradicional": a rede de agências}

Como nos lembra Jean Labasse (1955:94), "a carta de implantação de um Banco corresponde a um momento da evolução das técnicas", e daí a necessidade de sua análise mais cuidadosa. Além da análise do movimento dos créditos e depósitos realizados nos diferentes estados da Federação, pareceu-nos necessário dar destaque à rede-suporte deste processo de drenagem/irrigação de recursos do território ${ }^{137}$. A evolução recente da distribuição das agências bancárias mostrou-se um índice fiável para o entendimento dos usos do território em processo de consolidação.

É através da rede de agências que os bancos drenam os capitais presentes em cada lugar, e que permitem que a intermediação financeira se desenvolva. Esta "captação capilar", como denomina Luigi Fray (1961:53), é uma estratégia dos intermediários financeiros que "buscam elevar a propensão a poupar da coletividade de poupadores ou de recolher toda a poupança tida em forma líquida" da população (FRAY, op. cit.53). Com relação às agências propriamente ditas, nos ensina Natermes Teixeira que,

“(...) as agências bancárias assumem a condição de autênticos terminais, para o varejo, onde se dispõe, centralizadamente, de todas as possibilidades institucionais de operações e serviços financeiro-creditícios do mercado. Trata-se, com efeito, da disseminação do variado espectro operacional inerente à estrutura dos conglomerados financeiros"(TEIXEIRA, 2000:150).

Neste sentido, a tabela 26 mostra que houve pequena diminuição do número total de agências no território, apesar da enorme mudança ocorrida recentemente na estrutura de propriedade dos bancos no Brasil (privatização/concentração/desnacionalização). Conforme mostram tanto a tabela 26, como a 27, passamos de 17.400 agências no ano de 1994 (portanto, no início do Plano Real) para 17.260 no ano de 2004. Houve, assim, um decréscimo de 140 agências, ao analisarmos os dados para o

${ }^{137}$ No mesmo período em que Jean Labasse (1955) escreveu seu clássico sobre a rede bancária da região de Lyon, André Allix (1956:33) asseverava também que "a circulação do crédito, nestes dois sentidos, nutre e irriga (nourrit et irrigue) todos os órgãos vitais de uma sociedade humana". 
território como um todo. Atentando para a variação regional (e/ou estadual) do número de agências, vemos que há diferenças sensíveis entre o comportamento geográfico das redes bancárias em cada parcela do território. Estas especificidades regionais da topologia bancária indicam também "regiões perdedoras" e "regiões ganhadoras" em relação à rede nacional de agências bancárias.

Tabela 26: Brasil: Evolução da Topologia Bancária (Agências) nas Regiões Brasileiras, Exceto a Região Concentrada (1994-2004)

\begin{tabular}{|c|c|c|c|c|c|c|c|c|c|}
\hline & \multicolumn{3}{|c|}{ No. de Municípios } & \multicolumn{3}{|c|}{$\begin{array}{l}\text { No. de Agências } \\
\text { Bancárias }\end{array}$} & \multicolumn{3}{|c|}{$\begin{array}{c}\text { Municípios sem } \\
\text { Atendimento Bancário } \\
\text { por Agências }\end{array}$} \\
\hline & 1994 & 1998 & 2004 & 1994 & 1998 & 2004 & 1994 & 1998 & 2004 \\
\hline Acre & 23 & 23 & 22 & 41 & 23 & 31 & 9 & 17 & 10 \\
\hline Amapá & 4 & 16 & 16 & 18 & 14 & 23 & 10 & 12 & 10 \\
\hline Amaz & 73 & 73 & 62 & 136 & 119 & 132 & 42 & 44 & 29 \\
\hline Pará & 139 & 144 & 143 & 298 & 247 & 272 & 57 & 74 & 55 \\
\hline Rondô & 44 & 56 & 52 & 100 & 72 & 88 & 17 & 37 & 18 \\
\hline Rora & 8 & 5 & 15 & 21 & 13 & 17 & 0 & 12 & 10 \\
\hline Toca & 18 & 143 & & 90 & 0 & 8 & 85 & 119 & 101 \\
\hline NOR7 & 419 & 470 & 449 & 704 & 552 & 644 & 220 & 315 & 233 \\
\hline Alago & 99 & 103 & 11 & 162 & & 12 & 41 & 48 & 43 \\
\hline Bahia & 8 & & & 8 & & 746 & 70 & 90 & 82 \\
\hline Cear & & & & 388 & & 35 & 67 & 75 & 43 \\
\hline Mara & 7 & 2 & 2 & 292 & & 22 & 25 & 75 & 119 \\
\hline Para & 8 & $\bar{F}$ & & 190 & & 170 & 158 & 182 & 150 \\
\hline Pernan & 1 & 1 & & 508 & & 472 & 42 & 54 & 44 \\
\hline Piauí & 187 & 244 & 222 & 119 & 108 & 113 & 138 & 195 & 172 \\
\hline $\begin{array}{l}\text { Rio Gde. } \\
\text { do Norte }\end{array}$ & 152 & 167 & 167 & 137 & 123 & 133 & 95 & 122 & 121 \\
\hline Sergipe & 76 & 76 & 75 & 173 & 142 & $15 !$ & 15 & 19 & 18 \\
\hline $\mathrm{NOR}$ & 666 & 1.826 & 1.792 & 2.857 & 2.360 & 2.496 & 651 & 860 & 792 \\
\hline $\begin{array}{l}\text { Distrito } \\
\text { Federal }\end{array}$ & 9 & 9 & 17 & 241 & 256 & 304 & 0 & 0 & - \\
\hline Goiás & 233 & 243 & 246 & 589 & & 54 & 13 & 13 & 96 \\
\hline $\begin{array}{l}\text { Mato } \\
\text { Gross }\end{array}$ & 97 & 127 & 139 & 298 & 02 & 233 & 10 & 57 & 54 \\
\hline $\begin{array}{l}\text { Mato } \\
\text { Grosso do } \\
\text { Sul }\end{array}$ & 77 & 77 & 77 & 303 & 13 & 223 & 0 & 23 & 12 \\
\hline $\begin{array}{l}\text { CENTRO } \\
\text { OESTE }\end{array}$ & 416 & 456 & 479 & 1.431 & 200 & 303 & 23 & 83 & 165 \\
\hline $\begin{array}{l}\text { DEMAIS } \\
\text { REGIÕES }\end{array}$ & 2.501 & 2.752 & 2.720 & 4.992 & 4.112 & 4.443 & 894 & 1.258 & 1.190 \\
\hline $\begin{array}{l}\text { TOTAL } \\
\text { (BRASIL) }\end{array}$ & 11 & 5.597 & 5.578 & 17.400 & 16.002 & 17.260 & .137 & 1.739 & 1.743 \\
\hline
\end{tabular}

Fonte: Elaboração própria a partir de Banco Central do Brasil. CADIN/DEORF - UNICAD 
Além do comportamento regional da topologia bancária, as tabelas mostram ainda a capilaridade da rede de agências, já que indicam o número de municípios que não possuem este tipo de fixo geográfico para a prestação de serviços financeiros a sua comunidade.

Um primeiro dado para entendermos essa relação diz respeito ao que o geógrafo Marcio Cataia (2001) denominou de "multiplicação das fronteiras internas" do território brasileiro, isto é, a criação de novos municípios. De 1994 a 2004 foram criados nada menos que 567 novas municipalidades no país, número que pode ter interferido no decréscimo da relação agência/município.

No ano de 1994, o Brasil possuía 5.011 municípios, e as localidades sem agências eram 1.137, isto é, $22,7 \%$ dos municípios não contavam com esse importante fixo geográfico. No ano de 1998 essa porcentagem é de 31,0\% de municípios desassistidos, para chegarmos ao ano de 2004 com uma ausência de agências em $31,2 \%$ dos municípios brasileiros.

Tabela 27: Brasil: Evolução da Topologia Bancária (Agências) na Região Concentrada do Território Brasileiro (1994-2004)

\begin{tabular}{|l|r|r|r|r|r|r|r|r|r|}
\hline & \multicolumn{3}{|c|}{ No. de Municípios } & \multicolumn{3}{c|}{$\begin{array}{l}\text { No. de Agências } \\
\text { Bancárias }\end{array}$} & \multicolumn{3}{c|}{$\begin{array}{c}\text { Municípios sem } \\
\text { Atendimento } \\
\text { Bancário por } \\
\text { Agências }\end{array}$} \\
\hline & \multicolumn{3}{|c|}{} & \multicolumn{3}{c|}{} & \multicolumn{2}{c|}{} \\
\hline & $\mathbf{1 9 9 4}$ & $\mathbf{1 9 9 8}$ & $\mathbf{2 0 0 4}$ & $\mathbf{1 9 9 4}$ & $\mathbf{1 9 9 8}$ & $\mathbf{2 0 0 4}$ & $\mathbf{1 9 9 4}$ & $\mathbf{1 9 9 8}$ & $\mathbf{2 0 0 4}$ \\
\hline São Paulo & 620 & 646 & 646 & 5.021 & 5.015 & 5.549 & 10 & 36 & 30 \\
\hline Rio de Janeiro & 79 & 91 & 92 & 1.463 & 1.449 & 1.627 & 1 & 4 & 0 \\
\hline Minas Gerais & 757 & 854 & 853 & 1.878 & 1.783 & 1.834 & 128 & 234 & 306 \\
\hline Espírito Santo & 68 & 78 & 78 & 322 & 280 & 319 & 0 & 18 & 0 \\
\hline SUDESTE & 1.524 & 1.669 & 1.669 & 8.684 & 8.527 & 9.329 & 139 & 292 & 336 \\
\hline Paraná & 386 & 410 & 399 & 1.386 & 1.232 & 1.252 & 29 & 69 & 78 \\
\hline Santa Catarina & 262 & 295 & 293 & 833 & 781 & 828 & 44 & 45 & 41 \\
\hline $\begin{array}{l}\text { Rio Grande do } \\
\text { Sul }\end{array}$ & 338 & 471 & 497 & 1.505 & 1.350 & 1.408 & 31 & 65 & 98 \\
\hline SUL & 986 & 1.176 & 1.189 & 3.724 & 3.363 & 3.488 & 104 & 179 & 217 \\
\hline $\begin{array}{l}\text { REGIÃO } \\
\text { CONCENTRADA }\end{array}$ & 2.510 & 2.845 & 2.858 & 12.408 & 11.890 & 12.817 & 243 & 471 & 553 \\
\hline $\begin{array}{l}\text { TOTAL } \\
\text { (BRASIL) }\end{array}$ & 5.011 & 5.597 & 5.578 & 17.400 & 16.002 & 17.260 & 1.137 & 1.739 & 1.743 \\
\hline
\end{tabular}

Fonte: Elaboração própria a partir de Banco Central do Brasil. CADIN/DEORF - UNICAD 
Se acompanharmos a evolução da sístole (contração do número de agências) representada na tabela 27, vemos que também a Região Concentrada tem sua cobertura bancária por agências diminuída, no período pós-Plano Real. Significa dizer que, mesmo nesta parcela mais dinâmica do território, há diminuição da capilaridade da rede de agências. Das 12.408 agências existentes no ano de 1994, a Região Concentrada passa a abrigar 11.890 fixos geográficos deste tipo, no ano de 1998.

O Sudeste repete com números ainda mais expressivos essa tendência nacional. De apenas 139 cidades sem agências no ano de 1994, a região vê que 292 passam a não contar com tais fixos geográficos em 1998, chegando ao ano de 2004 com nada menos que 336 cidades sem agências bancárias: de cada 5 cidades do Sudeste, uma não possuía agência no ano de 2004. Há, com efeito, um crescimento de $141 \%$ de cidades desassisitidas.

O que no primeiro momento nos surpreende é o fato de que o número total de agências não diminui; ao contrário, como mostra ainda a tabela 27, o Sudeste, que abrigava 8.684 agências bancárias no ano de 1994 (nada menos que 50\% do total nacional), passa a contar com 9.329 no ano de 2004 (cerca de 54\% do total). O que ocorre, na verdade, é um processo de concentração das agências em pontos selecionados desta parcela do espaço nacional, em detrimento de áreas que são menos interessantes - do ponto de vista estritamente capitalista - para as atividades bancárias.

Uma análise mais pormenorizada do estado de São Paulo revela que ali houve uma redução do número de municípios que abrigavam agências: de 10 que eram desassitidos (1994), passamos a um total de 30 em 2004. E o mesmo fenômeno destacado para a Região Sudeste como um todo, se repete no estado: há aumento do número bruto de agências. De 5.021 que existiam no início do Plano Real (cerca de $29 \%$ dos totais nacionais), São Paulo passa a abrigar 5.549 agências em 2004 (pouco mais de 32\% da rede nacional). Não há, portanto, decréscimo nos 
números totais, mas sim uma alteração (concentração) na distribuição dos bancos no estado.

O estado do Rio de Janeiro também tem um crescimento no número bruto de agências: de 1.463, passa a contar com 1.627 fixos geográficos desse tipo no ano de 2004. Mas a distribuiç̧ão das agências em seu território é mais difusa do que no estado de São Paulo, já que em 2004 havia apenas um município sem agência no Estado. Uma geografia bancária semelhante possui o Espírito Santo: além de ter conseguido manter praticamente inalterado o número de agências que conta em seu território (de 322 em 1994 passa a ter 319 no ano de 2004), não existem ali municípios sem agência, no período compreendido entre os anos de 1994 e 2004.

A parcela da Região Sudeste que teve a maior sístole de rede bancária é sem sombra de dúvida o Estado de Minas Gerais. Apesar de conseguir manter também o número total de agências em seu território, há sensível perda da capilaridade da rede bancária mineira no período. De 128 municípios sem agências no ano de 1994, Minas Gerais passa a contar com nada menos que 306 cidades que não podem mais realizar operações de intermediação financeira mais sofisticadas, permitidas pelas agências bancárias. No limite do raciocínio, o estado mineiro foi em termos bancários - o mais prejudicado com o novo uso financeiro do território implementado pelo Plano Real.

O comportamento dos estados do Paraná e Rio Grande do Sul se assemelham muito, em termos de sua evolução recente. O território paranaense perde cerca de 134 agências no período 1994-2004, enquanto que no Rio Grande do Sul são fechadas 97 agências; o primeiro Estado vê sua rede diminuída em cerca de 10\%, o segundo perde cerca de 7\%. No número de municípios desprovidos de agências, o estado do Paraná conhece um sensível aumento: de 29 municípios que não possuíam alguma no ano de 1994, passamos a 78 cidades que não as tem (cerca de $20 \%$ dos municípios do Estado). No Rio Grande do Sul este processo não é 
menos expressivo: de 31 cidades sem agência, passamos a nada menos que 98 em 2004 , isto é, quase $20 \%$ dos municípios gaúchos deixam de contar com agências em seus territórios.

Diferentemente do que ocorrera no Paraná e Rio Grande do Sul, no Estado de Santa Catarina praticamente não há alteração do número de pontos da rede de agências. Além do Estado praticamente manter inalterado o número deste fixo geográfico na primeira década do Plano Real (de 833 em 1994 passa a contar com 828 em 2004), também uma maior capilaridade da rede ali é patente, pois o número de municípios desasssistidos no estado, na verdade, diminui: das 44 cidades que não possuíam agências em 1994, apenas 41 passam a não tê-las. Aumentou, portanto, a ação bancária através de agências nesta parcela do território brasileiro (ao contrário de todo o padrão observado na Região Concentrada).

E nas demais regiões do país, onde o meio técnico-científico informacional não se dá de forma contígua, densa, senão de maneira mais pontual ou "litoralizada"? Como se comporta o uso destas parcelas do território por parte da rede bancária brasileira?

Em primeiro lugar, parece ser necessário destacar que os números com relação à cobertura bancária nos estados das Regiões Nordeste, Centro-Oeste e Norte são mais modestos que os da Região Concentrada: a primeira região citada abrigava em 2004 apenas $14,4 \%$ da rede nacional de agências, a segunda região mencionada 7,5\%, cabendo ao Norte abrigar apenas $3,7 \%$ destes totais. O que dizer da evolução recente da rede de agências nestas porções do território brasileiro?

É importante ressaltar que há um padrão que se repete em todas as regiões, e que as distingue sobremaneira da Região Concentrada: há perda em termos absolutos de número de agências tanto no Norte, como no Nordeste e Centro-Oeste. Podese dizer, neste sentido, que o Nordeste é uma das regiões mais afetadas pelo Plano Real: das 2.857 agências que mantinha em 1994, passa a contar com apenas 2.496 em 2004; nada menos que 361 agências são fechadas nesta década que 
analisamos por ora. Se pensarmos em termos comparativos, esse número de agências fechadas é maior que toda a rede bancária do Espírito Santo (319 agências em 2004), e representa quase o triplo do número de agências do estado do Amazonas (132 agências em 2004).

Há perda também de controle da região em relação à distribuição desta rede bancária: os municípios sem banco crescem de 651 para 792, no período. Uma análise mais pormenorizada dos estados nordestinos nos mostra ainda que, com relação ao número bruto de agências, apenas o Rio Grande do Norte e o Piaú possuem diminuições menos expressivas: ambos perdem pouco menos de $10 \%$ de suas respectivas redes. Já nos demais estados, todos perdem um número significativo de agências em seus territórios. ${ }^{138}$

No que tange ainda à topologia bancária do Nordeste, apenas dois estados fazem "exceção à regra". No Ceará, há aumento da cobertura bancária por agências, já que de um total de 67 municípios sem atendimento bancário (1994), passa o estado a contar com apenas 43 no ano de 2004. Ainda que este número de municípios desassistidos seja relativamente baixo (representam 23,3\% do total de municípios do Estado), vê-se que esta parcela do território conseguiu expandir sua cobertura por agências, ao contrário do que ocorrera na maior parte do território ${ }^{139}$.

Chama a atenção também o comportamento da topologia bancária do Piauí. Apesar de ocorrer um aumento do número absoluto de agências no estado, não há concomitantemente uma capilarização deste fixo geográfico. Ao contrário, o número de municípios desassitidos aumentou sensivelmente para o período em tela: de 138 municípios sem agências, o Piauí passa a contar com 172 (2004).

\footnotetext{
138 Talvez o caso que mais chame a atenção seja o do estado da Bahia, que de 888 agências que possuía, passa a contar com apenas 746 (uma diminuição de 142 fixos geográficos!). Mas também o Maranhão vê uma quantidade expressiva de agências serem fechadas (67), assim como é o caso de Pernambuco (que perde 36 agências) e do Ceará (29 agências). Como mostra a tabela 26, o processo se repete em graus parecidos para todos os demais estados da Região.

139 O mesmo processo se passa no estado da Parába: se em 1994 havia 158 municípios sem atendimento bancário ali, no ano de 2004 esse número cai para 150. Em termos relativos, porém, a situação do estado é bem menos confortável: esses 150 municípios representam nada menos que $67,2 \%$ do total de cidades do Estado.
} 
Essas 172 cidades representam, por seu turno, nada menos que 77,4\% do número de municípios do estado. Esta proporção se repete também no Rio Grande do Norte: os 121 municípios que não possuíam agência bancária representavam também o impressionante número de $72,4 \%$ das municipalidades do estado. A propósito: em 2004, quase metade dos municípios nordestinos não contavam com agências bancárias (44,1\%, correspondentes a 792 cidades).

Uma maior ausência de agências talvez seja também a característica distintiva, específica, da Região Norte do país. Desde o início do Plano Real, o número de agências bancárias diminuiu de 90 para 81; e o número de municípios cresceu (passa de 419 para 449, como mostra a tabela 26). Já o número de municípios sem agência passa de 220 para 233; significa dizer que em 1994 cerca de 52,5\% dos municípios nortistas não possuíam agência em seu território, e em 2004 este índice é de 51,9\%.

Faz-se mister ressaltar ainda que nos estados de Roraima e Amapá há um grande número de municípios sem agências. Em 2004, eram 66,6\% dos municípios de Roraima que não a possuíam; no caso do Amapá, este índice era de $62,5 \%$.

Este é um quadro pormenorizado da evolução da topologia bancária do território, no que diz respeito a sua rede de agências. Pareceu-nos importante destacar esta evolução, pois as agências constituem o mais importante fixo geográfico para a prestação de serviços bancários. Já que vivemos numa fase em que as finanças jogam um papel decisivo na reprodução da vida das pessoas, das empresas, e do próprio Estado, as agências bancárias adquirem relevância acentuada no desenvolvimento regional, principalmente nas "áreas opacas" do território.

As agências bancárias são os elementos do espaço geográfico que permitem que o processo de circulação das finanças passe para as fases de produção/distribuição, concretamente, nas cidades e nas regiões nas quais estão instaladas. Mas não só por serem o "relais" do processo de circulação (fluxos) com os processos de 
organização das cidades/regiões (fixos) é que as agências são importantes. Por abrigarem especialistas em concessão/análise de crédito (os gerentes), entre outros profissionais conhecedores da vida econômica local, as agências se constituem em sistemas de ações essenciais para a promoção de políticas públicas (e/ou privadas) que aproveitem as especificidades dos lugares, com o máximo de eficiência no uso dos capitais locais nelas depositados.

Por último, as agências parecem fundamentais também para os municípios (principalmente os menores) pois são fixos geográficos que ajudam na dinamização da vida local aonde estão instaladas. Toda agência precisa ter no mínimo cinco funcionários para a concretização de suas funções: um gerente, um auxiliar administrativo, um caixa fixo, um "volante" (também conhecido como "office boy") e um segurança. Esta configuração mínima requer, em termos de salários, cerca de $\mathrm{R} \$ 20.000$,00/mês em gastos por parte do banco. Destarte, as agências podem ser consideradas como um tipo de fixo geográfico que injeta quantidade significativa de recursos na economia local da qual faz parte, e principalmente nos municípios menores, seu impacto se faz mais sensível.

A evolução recente da rede bancária brasileira, porém, tem seguido um caminho oposto ao da diástole, da expansão do número de agências, ao menos nas parcelas menos desenvolvidas do território. Ao contrário, os recentes processos de racionalização da rede (guiados pela privatização, desnacionalização e aumento da concorrência entre os bancos), conduziram a uma sístole da rede de agências. Além das agências, os Postos de Atendimento Bancários (PAB's) foram o outro fixo geográfico que mais perdeu importância relativa na rede bancária nacional.

\subsection{A evolução recente da topologia bancária: os Postos de Atendimento Bancário (PAB's)}

A diminuição do número de $P A B^{\prime}$ 's no território brasileiro foi bastante expressiva nesta última década. De um total de 10.125 existentes no ano de 1994, o território 
passa a contar com 7.211 em 1998, passando a comportar 6.677 Postos no ano de 2004. A análise dos Mapas 7 a 8, da Nossa Caixa S.A. nos permite melhor visualizar essa difusão dos PAB's no Estado e no Município de São Paulo.

Mas a distribuição regional dos Postos de Atendimento Bancário possui também suas especificidades. Na Região Concentrada do território (tabela 28) a velocidade e a dimensão da diminuição destes fixos geográficos é menor do que nas demais parcelas do território. Dos 7.632 Postos existentes em 1994, a Região passa a contar com 5.092 Postos. Ocorre, destarte, uma diminuição de cerca de 33,3\% no número de $P A B$ 's nesta região, onde o meio técnico-científico-informacional se dá de forma mais densa e contígua. Ao detalharmos melhor esta evolução, vemos que os estados que compõem a Região Sul do país é que apresentam a menor perda de PAB's no período: de 1.923 Postos que possuíam em 1994, passam a contar com 1.337 em 2004. Uma redução de 30,5\%, portanto.

Tabela 28: Brasil: Evolução da Topologia Bancária (Postos de Atendimento Bancário) na Região Concentrada (1994-2004)

\begin{tabular}{|c|c|c|c|c|c|c|c|c|c|}
\hline & \multicolumn{3}{|c|}{ No. de Municípios } & \multicolumn{3}{|c|}{ No. de PAB's } & \multicolumn{3}{|c|}{$\begin{array}{c}\text { Municípios somente } \\
\text { com PAB (Sem } \\
\text { Agência) }\end{array}$} \\
\hline & 1994 & 1998 & 2004 & 1994 & 1998 & 2004 & 1994 & 1998 & 2004 \\
\hline São Paulo & 620 & 646 & 646 & 3.696 & 2.716 & 2.538 & 27 & 27 & 43 \\
\hline Rio de Janeiro & 79 & 91 & 92 & 872 & 587 & 542 & 0 & 0 & 4 \\
\hline Minas Gerais & 757 & 854 & 853 & 975 & 677 & 572 & 46 & 31 & 79 \\
\hline Espírito Santo & 68 & 78 & 78 & 166 & 92 & 103 & 0 & 2 & 10 \\
\hline SUDESTE & 1.524 & 1.669 & 1.669 & 5.709 & 4.072 & 3.755 & 73 & 60 & 136 \\
\hline Paraná & 386 & 410 & 399 & 663 & 557 & 445 & 21 & 18 & 19 \\
\hline Santa Catarina & 262 & 295 & 293 & 417 & 344 & 369 & 2 & 1 & 32 \\
\hline $\begin{array}{l}\text { Rio Grande do } \\
\text { Sul }\end{array}$ & 338 & 471 & 497 & 843 & 556 & 523 & 34 & 6 & 142 \\
\hline SUL & 986 & 1.176 & 1.189 & 1.923 & 1.457 & 1.337 & 57 & 25 & 193 \\
\hline $\begin{array}{l}\text { REGIÃO } \\
\text { CONCENTRADA }\end{array}$ & 2.510 & 2.845 & 2.858 & 7.632 & 5.529 & 5.092 & 130 & 85 & 329 \\
\hline TOTAL (BRASIL) & 5.011 & 5.597 & 5.578 & 10.125 & 7.211 & 6.677 & 344 & 224 & 714 \\
\hline
\end{tabular}

Fonte: Elaboração própria a partir de Banco Central do Brasil. CADIN/DEORF - UINICAD 


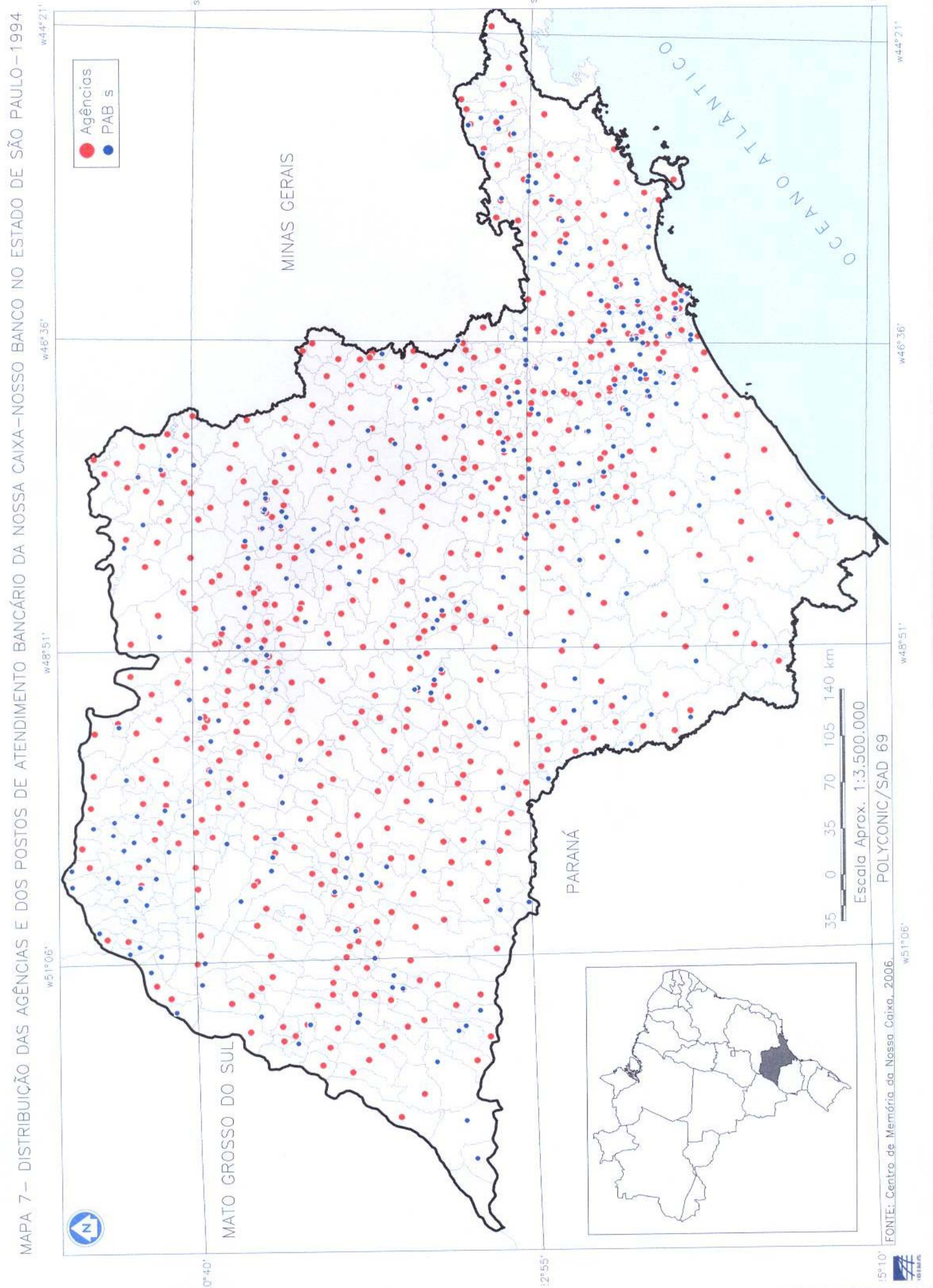


MAPA 8- DISTRIBUICÃO DAS AGÊNCIAS E DOS POSTOS DE ATENDIMENTO BANCÁRIO DA NOSSA CAIXA-NOSSO BANCO NO MUNICÍPIO DE SÃO PAULO-1994

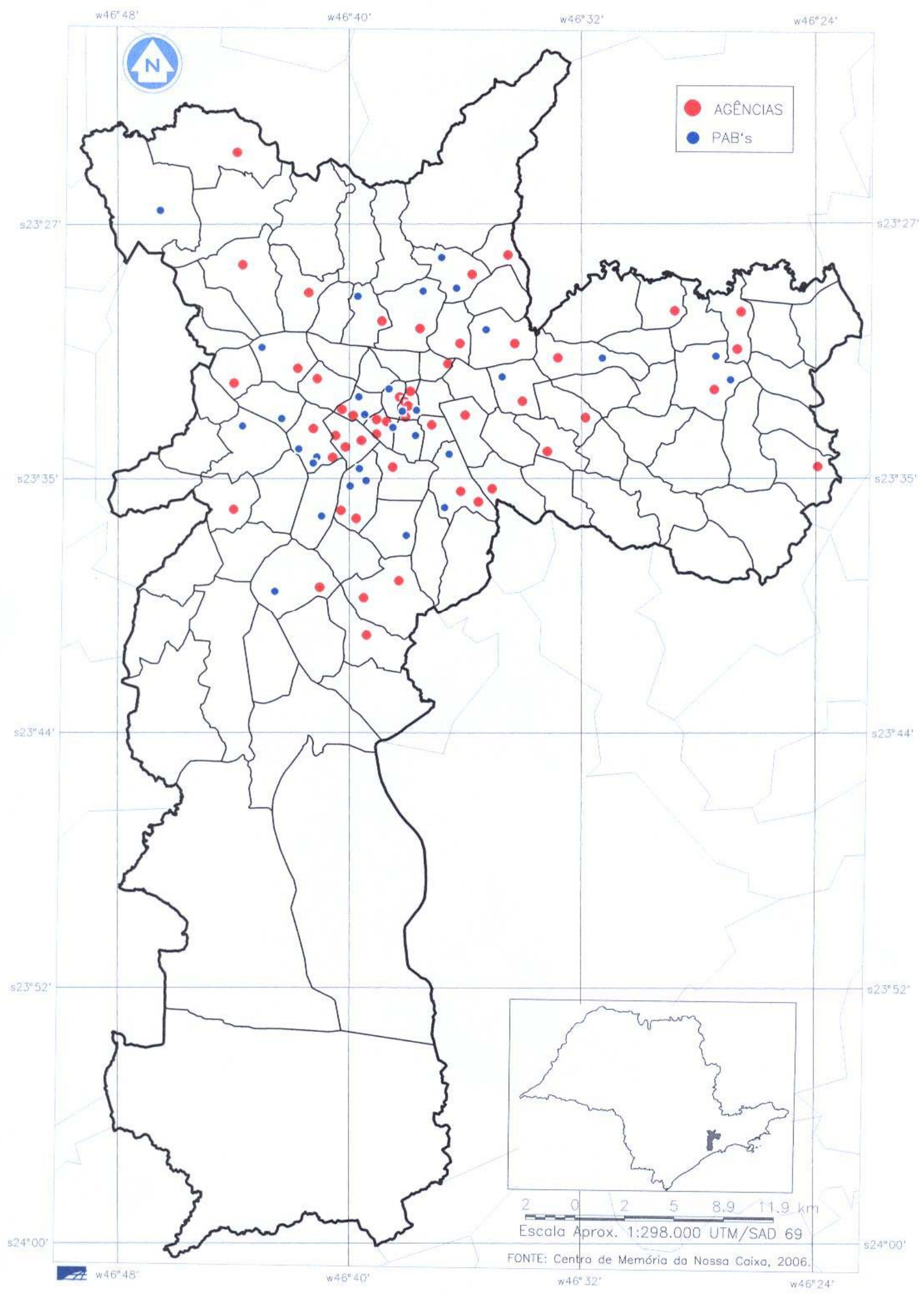


Já no Sudeste, a queda é um pouco mais sensível: dos 5.709 Postos em 1994, passa a contar com 3.755 no ano de 2004; perde, portanto, cerca de 34,3\% de seus Postos. Vale frisar ainda que os números brutos para a Região Sudeste são também dignos de nota: nada menos que 1.954 Postos são fechados no período, número maior que a quantidade de Postos existentes nas Regiões Norte, Nordeste e Centro-Oeste somadas (no ano de 2004).

Tabela 29: Brasil: Evolução da Cobertura Bancária (Postos de Atendimento Bancário) nas Regiões Brasileiras Exceto a Região Concentrada (1994-2004)

\begin{tabular}{|c|c|c|c|c|c|c|c|c|c|}
\hline & \multicolumn{3}{|c|}{ No. de Municípios } & \multicolumn{3}{|c|}{ No. de $P A B^{\prime}$ s } & \multicolumn{3}{|c|}{$\begin{array}{c}\text { Municípios somente } \\
\text { com PAB (Sem } \\
\text { Agência) }\end{array}$} \\
\hline & 1994 & 1998 & 2004 & 1994 & 1998 & 2004 & 1994 & 1998 & 2004 \\
\hline Acre & 23 & 23 & 22 & 25 & 15 & 14 & 2 & 0 & 5 \\
\hline Amapá & 14 & 16 & 16 & 9 & 10 & 3 & 0 & 1 & 3 \\
\hline Amazonas & 73 & 73 & 62 & 98 & 82 & 109 & 1 & 7 & 0 \\
\hline Pará & 139 & 144 & 143 & 175 & 137 & 127 & 11 & 7 & 30 \\
\hline Rondônia & 44 & 56 & 52 & 85 & 12 & 15 & 2 & 0 & 15 \\
\hline Roraima & 8 & 15 & 15 & 15 & 15 & 2 & 0 & 0 & 2 \\
\hline Tocantins & 118 & 143 & 139 & 17 & 14 & 15 & 4 & 0 & 15 \\
\hline NORTE & 419 & 470 & 449 & 424 & 285 & 322 & 20 & 15 & 60 \\
\hline Alagoas & 99 & 103 & 102 & 109 & 51 & 31 & 7 & 6 & 22 \\
\hline Bahia & 418 & 419 & 417 & 434 & 307 & 254 & 63 & 43 & 96 \\
\hline Ceará & 184 & 185 & 184 & 158 & 98 & 107 & 15 & 12 & 55 \\
\hline Maranhão & 137 & 192 & 217 & 74 & 62 & 45 & 11 & 10 & 11 \\
\hline Paraíba & 238 & 255 & 223 & 71 & 48 & 41 & 4 & 2 & 26 \\
\hline Pernambuco & 175 & 185 & 185 & 254 & 155 & 151 & 3 & 2 & 49 \\
\hline Piauí & 187 & 244 & 222 & 27 & 28 & 11 & 2 & 2 & 11 \\
\hline $\begin{array}{l}\text { Rio Gde. } \\
\text { do Norte }\end{array}$ & 152 & 167 & 167 & 91 & 50 & 4 & 10 & 1 & 4 \\
\hline Sergipe & 76 & 76 & 75 & 54 & 53 & 49 & 9 & 8 & 10 \\
\hline NORDESTE & 1.666 & 1.826 & 1.792 & 1.272 & 852 & 777 & 124 & 86 & 284 \\
\hline $\begin{array}{l}\text { Distrito } \\
\text { Federal }\end{array}$ & 9 & 9 & 17 & 233 & 214 & 233 & 0 & 0 & 0 \\
\hline Goiás & 233 & 243 & 246 & 305 & 217 & 136 & 69 & 43 & 8 \\
\hline $\begin{array}{l}\text { Mato } \\
\text { Grosso }\end{array}$ & 97 & 127 & 139 & 86 & 51 & 59 & 1 & 0 & 13 \\
\hline $\begin{array}{l}\text { Mato } \\
\text { Grosso do } \\
\text { Sul }\end{array}$ & 77 & 77 & 77 & 173 & 63 & 58 & 0 & 1 & 10 \\
\hline $\begin{array}{l}\text { CENTRO } \\
\text { OESTE }\end{array}$ & 416 & 456 & 479 & 797 & 545 & 486 & 70 & 44 & 31 \\
\hline $\begin{array}{l}\text { DEMAIS } \\
\text { REGIÕES }\end{array}$ & 2.501 & 2.752 & 2.720 & 2.493 & 1.682 & 1.585 & 214 & 145 & 375 \\
\hline $\begin{array}{l}\text { TOTAL } \\
\text { (BRASIL) }\end{array}$ & 5.011 & 5.597 & 5.578 & 10.125 & 7.211 & 6.677 & 344 & 224 & 714 \\
\hline
\end{tabular}

Fonte: Elaboração própria a partir de Banco Central do Brasil. CADIN/DEORF - UNICAD 
Nas demais regiões do país (Norte, Nordeste e Centro-Oeste), passamos de 2.493 fixos geográficos deste tipo em 1994 para 1.585 em 1994, como também atesta a tabela 29. Há, neste caso, diminuição de cerca de $36,5 \%$ dos totais de $P A B^{\prime}$ 's. A região do território que mais perde Postos é o Nordeste: de 1.272 que possuía em 1994, passa a conter 777 no ano de 2004; há um decréscimo de 39\% de seus PAB's. Na Região Centro-Oeste o decréscimo é de 39,1\% (de 797 passa a ter 485 Postos), e no Norte este decréscimo é de apenas $24,1 \%$.

A evolução da distribuição dos $P A B$ 's no território não sofreu alterações muito significativas nesta década analisada na tabela. A Região Concentrada, por exemplo, que possuía cerca de 75,3\% dos totais nacionais de Postos em 1994 (7.632), passa a comportar $76,2 \%$, no ano de 2004 .

Mas as tabelas 28 e 29 são indicativas também da capilarização deste tipo de cobertura bancária, isto é, trazem também dados acerca da existência (ou não) de municípios que possuem atendimento bancário somente por meio de Postos (e não por Agências).

Os municípios atendidos apenas por Postos passam de 344 para 714. Este aumento de pouco mais de $100 \%$ do número de municípios atendidos apenas por Postos indica que há perda de qualidade da distribuição dos serviços financeiros no território. Apesar do avanço do número de municípios com Postos de Atendimento, este tipo de fixo geográfico não possui a complexidade operacional que possui uma agência. A maior parte dos PAB's funciona com uma pequena quantidade de atendentes (os "caixas"), alguns contando com apenas um atendente.

A partir dos $P A B^{\prime} s$, portanto, não é possível realizar operações financeiras mais complexas, (repasses especiais, empréstimos para investimentos), que dependem da presença de um corpo de funcionários mais especializado, que só encontramos nas agências. 
Não foi possível identificar com precisão a causa específica dessa diminuição expressiva do número de Postos de Atendimento Bancário no território. Pode ser aventada a hipótese de que o próprio processo de privatização ocorrido nos anos 1990 tenha relação com esta diminuição, já que a topologia dos PAB's é bastante sensível à localização dos demais fixos públicos do território, como vimos no item 7.3.

Uma segunda hipótese, mais plausível, é a de que outro fixo geográfico tenha surgido como forma alternativa para prestar serviços bancários no território. Este parece ter sido o caso, sobremaneira, do surgimento dos correspondentes bancários no território.

\subsection{A forma contemporânea da topologia bancária: os Correspondentes Bancários}

A evolução da cobertura bancária no País pautou o oferecimento de serviços financeiros principalmente através da rede de agências dos bancos. Cada instituição, com sua topologia, utilizava (e utiliza) estes fixos geográficos para que a poupança dos atores financeiros seja drenada, e que estes mesmos atores consumam produtos financeiros, realizem empréstimos e se utilizem dos serviços bancários prestados em cada ponto da rede.

No período histórico atual, porém, passou a existir a possibilidade de uso de um novo fixo geográfico por parte das instituições financeiras: os correspondentes bancários. A partir das Resoluções de no. 2.640 (de 25 de agosto de 1999) e 2.707 (de 30 de março de 2000) do Banco Central, assinadas pelo então Presidente do Banco Central Armínio Fraga, os Bancos Comerciais e Múltiplos atuantes adquirem esta prerrogativa, que viria a alterar sensivelmente a topologia bancária do território. Mas o que vem a ser um correspondente bancário? 
Podemos considerar o correspondente como um fixo geográfico bastante simples do ponto de vista de sua operacionalidade; e, portanto, muito mais flexível em relação à sua localização potencial. São mais simples pelas instalações físicas necessárias à abertura de um correspondente: eles se localizam necessariamente dentro em algum estabelecimento comercial já em funcionamento: uma padaria, farmácia, casa lotérica, pequenos supermercados, lojas, locadoras de vídeo, entre outros. Ao contrário dos fixos geográficos "tradicionais" que sempre compuseram a topologia bancária brasileira (as agências), não é necessário dispêndio de capitais para a construção de infra-estrutura para instalar um correspondente.

Também pela quantidade de sistemas técnicos envolvidos na instalação de um correspondente, é possível falar que este é um fixo geográfico menos sofisticado (do ponto de vista operacional) que os "tradicionais". Basicamente, é necessária apenas a existência da rede de energia elétrica, linha(s) telefônica(s), um terminal de atendimento bancário (isto é, um computador do Banco contratante do correspondente) e um funcionário treinado para manipular esse computador.

No caso dos correspondentes da Nossa Caixa S/A, no Estado de São Paulo, não é necessária sequer uma ligação com a internet, para o funcionamento do correspondente. O sistema montado pela Caixa permite que o computador instalado no correspondente seja ligado com a agência bancária mais próxima através de tecnologia sem fio (wireless), mais especificamente através do sistema GPRS (General Packet Radio Service), tecnologia que utiliza freqüência de rádio, bastante semelhante àquela utilizada na telefonia celular do tipo GSM. Na maior parte dos correspondentes bancários, porém, é necessária também a existência de uma linha telefônica para que estes correspondentes transmitam seus dados para a agência à qual estão diretamente ligados.

Outra característica que permite entender esta enorme flexibilidade envolvida na instalação do correspondente diz respeito à questão da mão-de-obra utilizada. Aqui, o trabalhador não é um "bancário", como tradicionalmente é conhecido o funcionário das 
instituições financeiras. Ele não é sindicalizado pelas associações de classe dos bancários, e é treinado pela própria instituição financeira que instala o correspondente. Este funcionário executa operações também mais simples, como recebimento de contas de consumo (água, luz), pagamento de impostos, preenchimento de fichas para abertura de contas, venda de produtos financeiros, entre outros.

Há bancos que utilizam sua rede de correspondentes de forma mais agressiva, treinando os funcionários para a venda de produtos do banco, principalmente a concessão de créditos e a venda de produtos financeiros. De maneira geral, as operações realizadas por um correspondente bancário são: 1) abertura de contascorrente; 2) recebimento e pagamentos de contas; 3) recebimento e encaminhamento de pedidos de empréstimos e de financiamentos; 4) análise de crédito e cadastro; e 5) execução de cobrança de títulos, entre outros serviços.

A responsabilidade "financeira", isto é, as decisões últimas sobre a abertura de contas, a concessão ou não de créditos e empréstimos, é do Banco contratante do correspondente. No máximo a cada dois dias, o correspondente precisa "liquidar" as operações realizadas, com o Banco ao qual está associado (DOS ANJOS, 2006).

Se pensarmos em termos da evolução da capilarização dos serviços bancários, não há dúvida que os correspondentes significaram um aumento da acessibilidade da população aos serviços financeiros mais básicos. O aumento vigoroso do número destes fixos geográficos no território indica essa maior acessibilidade, como mostra a tabela 30:

Tabela 30: Brasil: Evolução da Qualidade dos Fixos Geográficos Financeiros no Território (2000-2005)

\begin{tabular}{|l|l|l|l|l|l|l|}
\hline & $\mathbf{2 0 0 0}$ & $\mathbf{2 0 0 1}$ & $\mathbf{2 0 0 2}$ & $\mathbf{2 0 0 3}$ & $\mathbf{2 0 0 4}$ & $\mathbf{2 0 0 5}$ \\
\hline Agências bancárias & 16.396 & 16.841 & 17.049 & 16.829 & 17.260 & 17.515 \\
\hline $\begin{array}{l}\text { Correspondentes } \\
\text { bancários }\end{array}$ & 13.731 & 18.653 & 35.511 & 36.474 & 46.035 & 69.546 \\
\hline $\begin{array}{l}\text { Demais fixos (PAB's, } \\
\text { ATM's) }\end{array}$ & 23.948 & 26.989 & 32.568 & 34.412 & 35.432 & 36.932 \\
\hline $\begin{array}{l}\text { Total de fixos } \\
\text { geográficos }\end{array}$ & 54.075 & 62.483 & 82.128 & 87.715 & 98.727 & 123.993 \\
\hline
\end{tabular}

Fonte: Elaboração Própria, com base em dados do Banco Central do Brasil e FEBRABAN, 2006 [disponível em http://www.febraban.org.br/Arquivo/Servicos/Dadosdosetor/2006/item02.asp) 
O atendimento "tradicional" (indicado na tabela pela evolução das agências bancárias) apresenta um aumento bastante tênue entre os anos de 2000 e 2005, de apenas 6,8\%. Já os correspondentes bancários apresentam um crescimento vertiginoso: no mesmo período, aumenta em 406,5\% sua participação na topologia bancária do território. Esta velocidade parece nos autorizar a entendê-los também como um dado da "aceleração contemporânea" (SANTOS, 1994; 1996), neste caso diretamente ligado à prestação de serviços bancários no país. No ano de 2001, isto é, apenas um ano após a permissão do uso de correspondentes por parte do Banco Central, seu número já é maior que o de agências; em 2002, a quantidade de correspondentes representa o dobro da quantidade de agências, e ultrapassa também o número de $\mathrm{PAB}^{\prime}$ s e Caixas Eletrônicos (ATM's) no território.

No caso da Nossa Caixa do Estado de São Paulo, como mostram os Mapas 9 e 10, existem instalados nada menos que 1.187 correspondentes em todos os municípios do estado. Na cidade de São Paulo, são 41 os correspondentes do Banco.

O que pode ser pensado, ainda com relação a esse aumento expressivo do número dos correspondentes bancários no Brasil? Quais os conteúdos do território que possuem relação com esse processo? Que tipos de realidades locais interferem na abertura de um correspondente bancário?

Em primeiro lugar, podemos creditar parte da causa dessa expansão ao próprio "meio ambiente construído" (SANTOS, 1994) das cidades brasileiras. Isto é, essa expansão parece ter relação direta com a existência prévia dos estabelecimentos comerciais que recebem os correspondentes bancários. Estes estabelecimentos (padarias, casas lotéricas, pequenos mercados etc.) se encontram, literalmente, em todos os municípios. Há já uma série de fixos geográficos existentes no território, bem localizados e freqüentados, que possibilitaram esse crescimento significativo dos correspondentes na topologia bancária brasileira. Essa realidade preexistente é que autorizou, em grande parte, a enorme capilarização deste tipo de ponto de atendimento no país. 


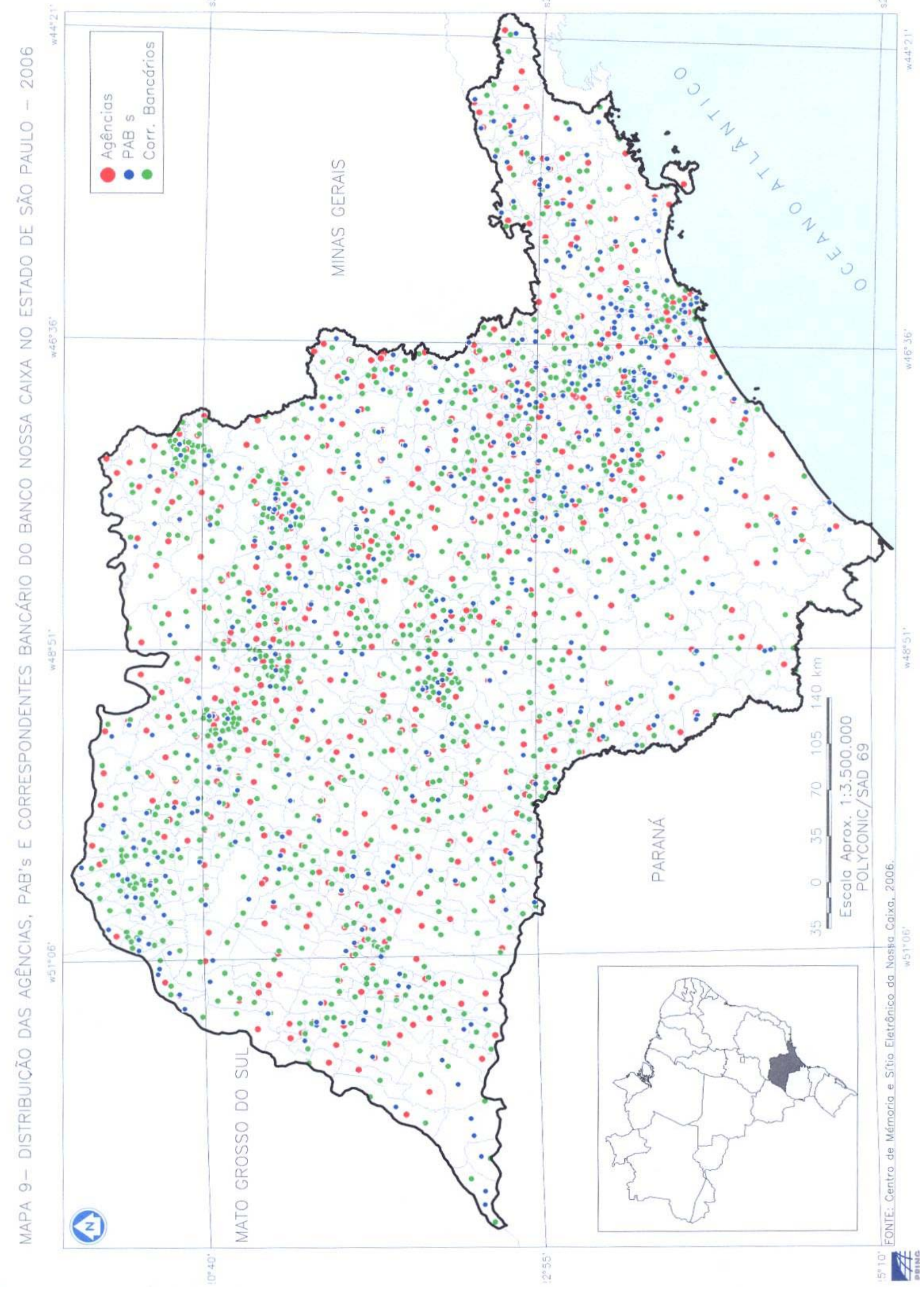


MAPA 10 - DISTRIBUICZ̃̃O DAS AGÊNCIAS, PAB'S E CORRESPONDENTES BANCÁRIOS DO BANCO NOSSA CAIXA NO MUNICÍPIO DE SÃO PAULO-2006

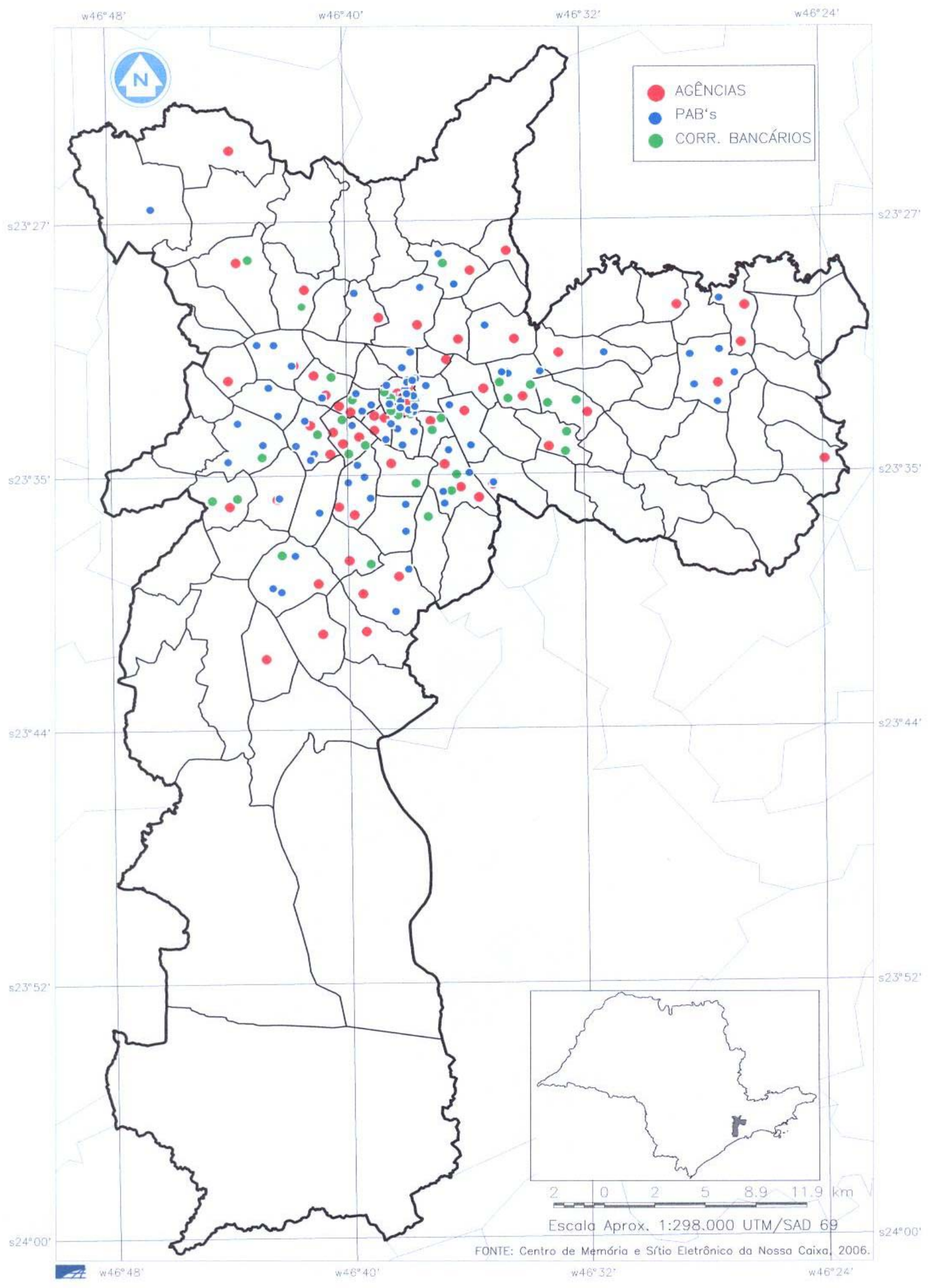


Em segundo, lugar, os correspondentes bancários parecem ter se difundido com bastante força pelo espaço nacional pois os usuários dos correspondentes geralmente são constituídos de uma população que tradicionalmente não possuía conta bancária. O fato de estarem locados em estabelecimentos "tradicionais", muitas vezes conhecidos pela população que os freqüenta, favorece o processo de "bancarização" desta população (CUSTÓDIO, 2003). Essa relação de familiaridade com o estabelecimento recebedor do Correspondente pode ser uma das causas desta profusão expressiva.

Há ainda razões ligadas às vantagens que o correspondente traz para os estabelecimentos comerciais que o abrigam. Podemos dividir estas vantagens em três tipos principais. Em primeiro lugar, o comerciante que decide abrir um ponto de correspondente bancário em seu estabelecimento aumenta o fluxo de clientes (e das vendas) em seu estabelecimento, já que uma nova função é cumprida, no mesmo imóvel. Em segundo lugar, ele aproveita o capital fixo já existente (o que poderíamos chamar também de "capacidades ociosas") de seu estabelecimento, como a rede de telefone, de eletricidade, seu espaço físico, assim como a própria localização de seu estabelecimento no espaço urbano, em proveito desta nova função instalada. Por último, tem sua atividade associada ao nome de um grande estabelecimento bancário, fato que aumenta a "visibilidade" de seu comércio na vida urbana local (DOS ANJOS, 2006).

Se há vantagens consideráveis para os pequenos comerciantes que abrigam os correspondentes, o que pode ser dito dos Bancos, que efetivamente são os implementadores dessa novidade no espaço geográfico? O que pode ser dito das vantagens para estes grandes atores, em relação aos correspondentes bancários?

Para os bancos contratantes, as vantagens da criação de correspondentes também não são pequenas. Dentre elas, pode ser destacada a maior acessibilidade que eles trazem em relação à população não-bancarizada do território. Em função da localização dos correspondentes, a distância física em relação à população não- 
bancarizada é menor. E em função ainda da simplicidade das operações típicas dos correspondentes (por exemplo, não é necessário mais a apresentação de comprovantes de renda para a abertura de contas), a distância "psicológica" também o é. Diminui-se o constrangimento usual que a população não-bancarizada sempre nutriu em relação às agências tradicionais. Assim, abriu-se um enorme contingente de brasileiros passíveis de serem bancarizados por intermédio deste fixo geográfico ${ }^{140}$.

Uma segunda e essencial vantagem para o sistema bancário é a economia em termos de capital físico por parte das instituições financeiras contratantes do correspondente. Essa economia provém do uso do "meio ambiente construído" (SANTOS, 1994), disponibilizado pelos estabelecimentos comerciais em funcionamento.

Por último, há também economia sensível de custos "operacionais", para a manutenção do sistema de ações nos correspondentes. Por serem fixos geográficos cujos trabalhadores realizam operações mais simples, é possível que os Bancos treinem e contratem uma mão-de-obra menos especializada, realizadora de operações básicas pouco complexas em termos operacionais, como: manipular o terminal (computador) instalado no correspondente. A vantagem principal em termos da mão-de-obra utilizada, porém, reside ainda em outro fator: por não serem considerados "bancários" (nos termos da legislação trabalhista), os funcionários dos correspondentes não possuem os direitos que a categoria sindicalizada tem (em relação à jornada de trabalho, ao piso salarial mínimo e à participação nos lucros do Banco, principalmente).

Esta é uma das principais querelas a respeito da relação trabalhista entre os bancários e os bancos. Para os sindicatos dos bancários, houve grande fechamento de postos de trabalho em função do surgimento deste novo canal de prestação de

140 Cálculos da Caixa Econômica Federal mostravam que no ano de 2003, havia cerca de "26 milhões de domicílios não-bancarizados no país"(CUSTÓDIO, 2003). Segundo ainda dados do Banco Bradesco, em 2005 existiam ainda "45 milhões de pessoas fora do sistema financeiro"(BRADESCO, 2006). 
serviços; calcula-se que em 2003, “os correspondentes bancários fizeram 595.000 operações de recebimentos - o que, na conta de sindicalistas, representaria o fechamento de cerca de 7.000 vagas"(PHOEBUS, 2006).

Estes são alguns dos elementos que nos permitem entender porque esse fixo geográfico conheceu um desenvolvimento tão expressivo no território brasileiro, num curto prazo de tempo. Dados da FEBRABAN indicam que atualmente há uma capilarização completa dos correspondentes no território, dada sua presença em 100\% dos municípios brasileiros. As estatísticas mais recentes do Banco Central sobre a distribuição regional deles, porém, mostram que até o ano de 2002 ainda havia municípios sem a presença deste fixo geográfico (tabela 31 ).

A quantidade de municípios assistidos apenas por correspondentes bancários é possivelmente um dos dados mais importantes da tabela 31. Nada menos que 1.577 municípios brasileiros (cerca de $27,8 \%$ do total de municípios do país) tinham neste fixo geográfico o seu "relais" principal com o sistema bancário nacional.

É também interessante notar que há uma maior difusão (tanto em termos relativos, quanto em termos absolutos) dos correspondentes nas "áreas opacas" do território brasileiro. Se atentarmos para o número de correspondentes bancários em relação à quantidade de municípios de cada região, veremos que na Região Norte, por exemplo, a proporção dos municípios que possuíam dependência total dos correspondentes era bastante significativa: dos 470 municípios da região, um total de 239 eram assistidos somente pelos correspondentes. Significa dizer que nada menos que 50,8\% dos municípios da Região tinham em 2002 nos correspondentes a única forma de acesso aos serviços básicos do sistema bancário. 
Tabela 31: Brasil: Distribuição dos Correspondentes Bancários no Território (2002)

\begin{tabular}{|c|c|c|c|c|c|}
\hline $\begin{array}{l}\text { ESTADOS E } \\
\text { REGIÃO }\end{array}$ & $\begin{array}{c}\text { Número } \\
\text { de } \\
\text { Municípios }\end{array}$ & $\begin{array}{c}\text { Total de } \\
\text { Correspondentes }\end{array}$ & $\begin{array}{c}\text { Municípios } \\
\text { Atendidos } \\
\text { somente por } \\
\text { Correspondente }\end{array}$ & $\begin{array}{l}\text { Municípios } \\
\text { sem } \\
\text { Atendimento } \\
\text { Bancário }\end{array}$ & $\begin{array}{l}\text { Municípios sem } \\
\text { Atendimento } \\
\text { considerando os } \\
\text { Correspondentes }\end{array}$ \\
\hline Alagoas & 103 & 192 & 44 & 44 & 0 \\
\hline Bahia & 418 & 863 & 84 & 84 & 0 \\
\hline Ceará & 184 & 438 & 45 & 45 & 0 \\
\hline Maranhão & 216 & 378 & 91 & 91 & 0 \\
\hline Paraíba & 251 & 394 & 150 & 177 & 27 \\
\hline Pernambuco & 185 & 500 & 44 & 45 & 1 \\
\hline Piauí & 240 & 369 & 170 & 190 & 20 \\
\hline R. G. do Norte & 167 & 343 & 121 & 122 & 1 \\
\hline Sergipe & 76 & 266 & 19 & 20 & 1 \\
\hline NORDESTE & 1.840 & 3.743 & 768 & 818 & 50 \\
\hline Acre & 23 & 38 & 13 & 13 & 0 \\
\hline Amapá & 16 & 28 & 9 & 10 & 1 \\
\hline Amazonas & 73 & 169 & 29 & 40 & 11 \\
\hline Pará & 144 & 324 & 57 & 59 & 2 \\
\hline Rondônia & 56 & 123 & 20 & 23 & 3 \\
\hline Roraima & 16 & 28 & 10 & 11 & 1 \\
\hline Tocantins & 142 & 210 & 101 & 104 & 3 \\
\hline NORTE & 470 & 920 & 239 & 260 & 21 \\
\hline Distrito Federal & 17 & 199 & 0 & 3 & 3 \\
\hline Goiás & 246 & 557 & 44 & 45 & 1 \\
\hline Mato Grosso & 142 & 249 & 57 & 59 & 2 \\
\hline Mato G. do Sul & 77 & 204 & 12 & 12 & 0 \\
\hline CENTRO-OESTE & 482 & 1.209 & 113 & 119 & 6 \\
\hline Espírito Santo & 78 & 234 & 0 & 1 & 1 \\
\hline Minas Gerais & 854 & 1822 & 230 & 231 & 1 \\
\hline Rio de Janeiro & 92 & 917 & 1 & 1 & 0 \\
\hline São Paulo & 646 & 2820 & 26 & 28 & 2 \\
\hline SUDESTE & 1.670 & 5.793 & 257 & 261 & 4 \\
\hline Paraná & 401 & 889 & 61 & 64 & 3 \\
\hline Rio Gr. do Sul & 501 & 1021 & 98 & 101 & 3 \\
\hline Santa Catarina & 294 & 574 & 41 & 42 & 1 \\
\hline SUL & 1.196 & 2.484 & 200 & 207 & 7 \\
\hline $\begin{array}{l}\text { REGIÃO } \\
\text { CONCENTRADA }\end{array}$ & 2.866 & 8.277 & 457 & 468 & 11 \\
\hline TOTAL & 5.658 & 14.149 & 1.577 & 1.665 & 88 \\
\hline
\end{tabular}

Fonte: Banco Central do Brasil (2006)

Na Região Nordeste, a proporção dos correspondentes no atendimento da população possui também proporções semelhantes. De seus 1.840 municípios, um total de 768 era atendido somente por correspondentes; isto é, cerca de 41,7\% 
de suas cidades têm nesse fixo geográfico a forma concreta de inserção na rede do sistema bancário nacional.

No Centro-Oeste, os correspondentes bancários não possuem uma inserção tão significativa, pelo que constam dos dados da tabela 31 . Cerca de $23,4 \%$ dos municípios (113 dos 482) tinham apenas correspondentes como forma de prestação de serviços bancários. Por fim, mas não menos importante, podemos ver que a Região Concentrada também não tem nos correspondentes uma forma tão expressiva de capilarização do sistema bancário: no ano de 2002, apenas 457 de seus 2.866 municípios dependiam estritamente dos correspondentes; vale dizer, apenas $15,9 \%$ dos municípios nesta região abrigavam apenas este fixo geográfico financeiro.

Dadas estas características gerais de funcionamento da rede de correspondentes bancários no país, boa parte das instituições financeiras (bancos grandes, médios e pequenos) se lançou no território através do uso dos correspondentes, para além de suas redes de Agências já constituídas. A tabela 32 nos mostra os principais bancos que abriram correspondentes bancários no país, a partir do ano de 2001.

Este é o quadro que revela a utilização por parte dos bancos de correspondentes no território brasileiro, entre 2001 e 2004. Como já fora notado neste item da tese, chama-nos a atenção a velocidade com que estes fixos geográficos são criados. No período descrito, o crescimento do número de Correspondentes é da ordem de $170 \%$, para o território brasileiro como um todo.

Com relação ao controle da rede de correspondentes bancários, vemos que há relativo equilíbrio na divisão do trabalho entre bancos públicos e bancos privados que deles se utilizam. Os bancos públicos detinham cerca de $52 \%$ da rede $(19.901$ correspondentes) e a rede bancária privada os restantes $48 \%$ (18.350) no ano de 2004. 
Tabela 32: Brasil: Evolução dos Correspondentes Bancários no Território (por Banco Contratante) (2001-2004)

\begin{tabular}{|c|c|c|c|c|c|}
\hline Contratante & Conglomerado & 2001 & 2002 & 2003 & 2004 \\
\hline \multicolumn{6}{|l|}{ Bancos Públicos } \\
\hline C. Econ. Fed. & & 9.078 & 12.232 & 12.702 & 14.268 \\
\hline Banco do Brasil & $\mathrm{BB}$ & 265 & 1.082 & 1.182 & 4.695 \\
\hline Nossa Caixa & & & 16 & 172 & 845 \\
\hline Banese & & 1 & 66 & 70 & 93 \\
\hline $\begin{array}{l}\text { Total dos bancos } \\
\text { públicos }\end{array}$ & & 9.344 & 13.396 & 14.126 & 19.901 \\
\hline \multicolumn{6}{|l|}{ Bancos Privados } \\
\hline Lemon Bank & & & 1.740 & 4.642 & 5.579 \\
\hline Bradesco & Bradesco & & 2.689 & 4.276 & 4.276 \\
\hline ABN/Real & ABN Amro & 2.502 & 3.469 & 3.516 & 3.516 \\
\hline Banco BMG & $\mathrm{BMG}$ & 501 & 568 & 760 & 760 \\
\hline Lloyds TSB & HSBC & 184 & 343 & 608 & 608 \\
\hline Unibanco & Unibanco & & 348 & 404 & 405 \\
\hline Investcred & Unibanco & & & 348 & 348 \\
\hline Panamericano & SS & 271 & 327 & 327 & 327 \\
\hline Fininvest & Unibanco & 132 & 132 & 318 & 318 \\
\hline ASB CFI & & 128 & 180 & 210 & 210 \\
\hline $\begin{array}{l}\text { Malcon } \\
\text { Financeira CFI }\end{array}$ & Madel Malcon & 167 & 174 & 180 & 180 \\
\hline Banco Matone & Matone & 22 & 136 & 176 & 176 \\
\hline $\begin{array}{l}\text { Itaucred } \\
\text { Financiamentos }\end{array}$ & Itaú & 128 & 138 & 138 & 138 \\
\hline Banco Ibi & Ibibank & 81 & 102 & 137 & 137 \\
\hline Banco Finasa & Bradesco & 42 & 100 & 110 & 110 \\
\hline Banco Schahin & Schahin & 5 & 5 & 105 & 105 \\
\hline Banco Cargill & & 103 & 103 & 103 & 103 \\
\hline Banese & & 1 & 66 & 70 & 93 \\
\hline Omni CFI & Omni & 56 & 79 & 89 & 89 \\
\hline Banco Alvorada & Bradesco & 83 & 83 & 86 & 86 \\
\hline Banco Citibank & Citibank & 30 & 63 & 74 & 74 \\
\hline Portocred CFI & & 63 & 68 & 68 & 68 \\
\hline Banco Pine & Pine & & & 66 & 66 \\
\hline Banco Morada & & & 26 & 64 & 64 \\
\hline Banco BBM & BBM & 61 & 61 & 61 & 61 \\
\hline \multicolumn{2}{|l|}{ Demais bancos } & 212 & 379 & 432 & 453 \\
\hline \multicolumn{2}{|c|}{ Totais Bancos Privados } & 4.772 & 11.379 & 17.368 & 18.350 \\
\hline \multicolumn{2}{|l|}{ Totais Brasil } & 14.115 & 24.709 & 31.424 & 38.158 \\
\hline
\end{tabular}

Fonte: Elaboração própria a partir de dados do Banco Central do Brasil. Defin/Dinfo e Deorf/Copec (2006).

Quais as características principais que diferenciam as redes de correspondentes de bancos privados, daquelas dos bancos oficiais? Para tentar entender melhor as características destas duas topologias, passemos à análise do funcionamento de 
duas das principais redes: a) a rede de correspondentes da Caixa Econômica Federal; e b) a rede do "Banco Postal", pertencente ao BRADESCO (a maior instituição financeira privada nacional).

10.5.1. Os correspondentes bancários da Caixa Econômica Federal: os "nervos do governo"

A Caixa Econômica Federal é, sem sombra de dúvidas, a mais importante instituição pública que se utilizou dos correspondentes bancários para expandir sua rede de prestação de serviços bancários no país. Nada menos que 37,4\% de todos os correspondentes no território eram de propriedade da Caixa Econômica, no ano de 2004.

Como mostra o trabalho de Carlos Henrique Custódio (2003), essa expansão dos correspondentes da Caixa Econômica Federal teve como principal objetivo "criar condições favoráveis para fomentar e democratizar o acesso aos produtos e serviços financeiros de forma a promover a inserção social" de uma população não-bancarizada. E de fato a expansão deste tipo de fixo geográfico tornou muito mais capilar a oferta de serviços bancários no território. No estado de Roraima, como nos mostra o sítio eletrônico da instituição, encontramos correspondentes instalados em todos os municípios do Estado: Amajari, Normandia, Uiramuta, Caroebe, Iracema, Bonfim, São Luiz, além da capital Boa Vista.

No Piauí, esta capilaridade profunda também é encontrada. São nada menos que 147 municípios atendidos, como por exemplo: Wall Ferraz, Vila Nova do Piaú, Tanque do Piauí, São Miguel da Baixa Grande, São João da Varjota, Pavussu, Jurumenha, Curralhinhos, entre tantos outros. A mesma capilaridade se apresenta, ao analisarmos a distribuição dos correspondentes da Caixa nas demais "áreas opacas" do território. Estes são exemplos de como a rede estabelecida com os correspondentes aumentou o alcance do serviço, catalisando assim a 
"bancarização" de uma população que dificilmente o seria pela topologia bancária "tradicional" (agências e PAB's).

A análise do trabalho de Carlos Henrique Custódio (2003) traz ainda outro elemento significativo para entendermos a importância dos correspondentes na dinâmica atual da topologia bancária brasileira. No caso da rede instalada pela Caixa Econômica Federal, os correspondentes acabam por servir como um poderoso instrumento de difusão das políticas públicas do Governo Federal.

No ano de 2002 foram pagos pela rede bancária da Caixa cerca de $\mathrm{R} \$ 36,2$ bilhões em "benefícios sociais", sendo as principais despesas nas seguintes rubricas: R\$ 19, 6 bilhões do Fundo de Garantia por Tempo de Serviço (FGTS); $\mathrm{R} \$$ 9,8 bilhões de aposentadorias e pensões (Previdência Social); e cerca de R\$ 5,5 bilhões gastos com o chamado seguro-desemprego (CUSTÓDIO, 2003). Supondo que nas "áreas opacas" do território esses recursos públicos são ainda mais importantes, é possível afirmarmos que a capilaridade dos correspondentes da Caixa Econômica Federal auxilia a eficiência da chegada dos benefícios sociais para as populações mais carentes, nos seus respectivos municípios de residência.

Mas a topologia dos correspondentes da Caixa Econômica Federal se mostra ainda mais importante em sua relação com a chamada "rede de proteção social" do Governo Federal, isto é, aquele conjunto de políticas públicas da União especificamente destinado para as populações de menor poder aquisitivo. Esta população, como mostram os estudos de João Paulo dos Reis Veloso (2004) e de Sonia Rocha e Roberto Cavalcanti de Albuquerque (2004), está localizada preferencialmente no Norte e Nordeste do país, assim como na periferia das áreas metropolitanas do território brasileiro (ALMEIDA, 2001). E foi justamente nessas áreas que se instalou a maior parte dos correspondentes bancários, como tivemos a oportunidade de frisar. 
O Programa Bolsa-Família (criado pelo atual Presidente Luis Inácio Lula da Silva) é também uma política pública cujos repasses são realizados através da rede bancária da Caixa Econômica Federal. A topologia desta instituição financeira se revela, neste sentido, como um dado estratégico para a concretização de tais políticas. E de fato, o número de famílias que recebem atualmente recursos deste Programa é bastante significativo.

Quadro 8: Brasil: Quantidade de Famílias Beneficiadas pelos Programas Sociais do Governo Federal (2006)

\begin{tabular}{|l|r|}
\hline Tipo de Benefício & No. de Famílias \\
\hline Bolsa Família & 11.098 .076 \\
\hline Bolsa Escola & 70.654 \\
\hline Bolsa Alimentação & 2.653 \\
\hline Auxílio Gás & 636.736 \\
\hline
\end{tabular}

Fonte: Ministério do Desenvolvimento Social. Programa Bolsa Família. 2006. Disponível em http://www.mds.gov.br/adesao/mib/matrizviewbr.asp?

A rede de correspondentes da Caixa Econômica Federal se constitui, assim, como um sistema de pontos de atendimento bastante capilarizado, e que permite que políticas públicas do Governo Federal (principalmente) atinjam cirurgicamente as populações mais carentes do território, nos exatos lugares onde elas vivem. Para usar o conceito do politólogo norte-americano Karl Deutsch (1971), esta rede acaba por se comportar como se fosse os "nervos do governo", levando parte das decisões do poder central da Federação aos pontos mais distantes do território, aumentando a coesão da população-alvo em torno deste centro de tomada de decisões.

10.5.2. A união entre o Bradesco e a rede dos Correios: o Banco Postal

No segundo semestre do ano de 2001, o Banco BRADESCO ganhou uma concorrência pública que deu direito à instituição de utilizar a rede de agências dos Correios em todo o território brasileiro, para a instalação de seu sistema de 
correspondentes bancários. Para isso, o Banco desembolsou a quantia de R $\$ 200$ milhões, criando o chamado Banco Postal no Brasil.

Atualmente a rede de cobertura dos Correios atinge 4.843 municípios no território brasileiro; estão espalhadas por estes municípios cerca de 12.000 agências dos Correios. Sobre esta base bastante capilarizada, o Bradesco tem instalado atualmente 5.550 correspondentes bancários (BRADESCO, 2006).

Na cidade de São Paulo, por exemplo, das 278 agências de Correios existentes, 107 possuem Bancos Postais (CORREIOS, 2006). Um total de $38,4 \%$ das agências, portanto, prestam também serviços financeiros para a população da região. Na cidade de Manaus (Região Norte do país), das 30 agências dos Correios, 19 possuem um Banco Postal; cerca de 63,3\% das agências abrigam também um Banco. Em Tefé, no interior do Estado do Amazonas, a coincidência entre a prestação de serviços postais e bancários é de 100\%: a única agência dos correios do município abriga um Banco Postal.

No que diz respeito ao funcionamento do Banco Postal, duas especificidades merecem ainda ser lembradas. Em primeiro lugar, a utilização da rede de agências de Correios é um elemento estratégico; por ser possivelmente o circuito mais capilarizado dos chamados "serviços públicos" de qualquer território (BAKIS, 1987; MATELLART, 1998) a utilização da rede dos Correios traz grande vantagem para a difusão da ação do Bradesco no território. Através do uso desta rede é possível atingir a totalidade dos municípios brasileiros. Este Banco se credencia, assim, a drenar a favor de seu sistema de ações uma quantidade enorme de depósitos, além de aumentar sensivelmente as possibilidades de realização de operações bancárias sob seu controle.

Uma segunda especificidade está relacionada com os dados da base técnica, na qual se instala a rede do Banco Postal. Se no período técnico do território (antes de 1945), os pontos de atendimento bancário necessitavam das redes ferroviárias 
para se instalar (LABASSE, 1955:45; SAES, 1981; 1986b), desde ao menos a década de 1970, são as tecnologias da telecomunicação/informação que permitem uma difusão ainda mais banalizada dos serviços bancários no país (BRAGA, 2003). Sendo as agências dos Correios especializadas na circulação de informações, podem ser consideradas como um circuito geográfico privilegiado para a instalação de uma rede de prestação de serviços bancários ${ }^{141}$.

Estas são as características do funcionamento do fixo geográfico-financeiro típico do atual período histórico. A extrema capilaridade que os correspondentes bancários concedem à topologia bancária brasileira aumenta o poder das instituições financeiras no controle da riqueza gerada no território. Na década de 1990 seria acrescentada ainda a esta rede de fixos geográficos uma série de sistemas técnicos informacionais, que aumentariam ainda mais o alcance dos fluxos financeiros no espaço geográfico nacional: são os chamados novos "canais eletrônicos" financeiros.

\footnotetext{
${ }^{141}$ Vale lembrar que também em função de que os Correios já prestam serviços financeiros há algum tempo (cheques postais, transferências de fundos), não só o sistema de objetos das agências é bastante "aderente" à nova função, como também seu sistema de ações, que se baliza por um "saber-fazer" financeiro há algum tempo.
} 


\section{CAPÍTULO 11. Os Novos Canais Eletrônicos e a Hipercapilaridade das}

Finanças

O aumento da importância das finanças na vida cotidiana das pessoas, do Estado e dos agentes econômicos não é um fenômeno recente. Este processo, na verdade, vem se constituindo desde que os sistemas bancários começam a assumir uma função destacada na divisão social do trabalho, já no início do século XX. Nicolai Bukharin (1915,1969:71) mostrava que "o capital financeiro é, certamente, a forma de capital mais penetrante, que, como a natureza, sofre disso que outrora se chamava de horror vacui, e sente necessidade de encher qualquer vazio que encontre".

Também o geógrafo Jean Labasse (1976:25) propunha em seu livro sobre o espaço financeiro, que existe, na verdade, uma "vontade colonizadora das redes" bancárias, que impele as infra-estruturas financeiras para os lugares onde é possível drenar recursos (captar depósitos, vender produtos financeiros) e/ou irrigar áreas [concessão de empréstimos] a partir destas infra-estruturas.

A entrada do território brasileiro no período técnico-científico-informacional possibilitou o desenvolvimento de uma série de novos fixos geográficos, sistemas de objetos e novos produtos oferecidos pelos bancos, que aproximaram de forma expressiva (física e organizacionalmente) os fluxos financeiros da população brasileira. As formas tradicionais da topologia bancária vêm se alterando em função desta nova realidade técnica e organizacional. De uma topologia fundamentalmente estruturada em agências, passamos para um tipo mais diversificado de redes bancárias, com a incorporação dos Postos de Atendimento Bancário e dos Correspondentes Bancários à rede-suporte de prestação de serviços financeiros.

Concomitantemente ao processo de diversificação e capilarização dos fixos geográficos que servem para a realização da intermediação financeira no território, há uma série nova de pontos de atendimento e canais de prestação de serviços financeiros que multiplicaram ainda mais a acessibilidade dos atores econômicos à finança. A essa maior banalização do acesso à finança, permitida pelos novos 
conteúdos da formação socioespacial brasileira, é que estamos propondo dar o nome de hipercapilaridade das finanças no território.

Esta hipercapilaridade seria o resultado da topologia atual do sistema bancário que descrevemos nos itens anteriores, e que alcançou recentemente todos os municípios do território. Mas ela tornou-se possível também pelo surgimento de novos sistemas técnicos - fixos e portáteis - que alcançam, de maneira ao mesmo tempo banalizada e seletiva, pontos do território antes "isolados" das redes financeiras. Estes novos sistemas técnicos são os "canais eletrônicos" financeiros, e com eles é aumentado o potencial invasor da racionalidade financeira nos diversos conteúdos do território brasileiro.

São considerados "canais eletrônicos financeiros" todos aqueles meios que permitem que uma operação financeira entre dois ou mais atores seja realizada. Os terminais ou caixas eletrônicos, as redes de internet banking, centrais de atendimento telefônico, pontos de recebimento de cartões de crédito e débito são todos exemplos de novos canais eletrônicos que vêm se somar à topologia tradicional do sistema financeiro brasileiro, conferindo a ela um alcance social e geográfico bastante amplificado.

De maneira resumida, podemos dizer que esses novos "canais" e sistemas técnicos que surgem (e se banalizam) recentemente no sistema financeiro têm papel decisivo nos seguintes elementos do sistema bancário e financeiro brasileiro:

1) contribuem para 0 aumento da produtividade do trabalho nos bancos (ACCORSI, 1990; INSTITUTO MCKINSEY, 1999; SILVA, 1999; JINKINGS, 2002; VILHENA e SICSÚ, 2004);

2) alteram em termos quantitativos e qualitativos as relações com os clientes bancários (COSTA FILHO, 1996; ALBERTIN, 1999; DINIZ, 2000);

3) modificam ainda a relação do sistema bancário com o território propriamente dito (CORRÊA, 1989; 1989, 2006; PIRES, 1997; PINTO, 2001; DE CARVALHO, 2003 e DIAS, 1995; 2005). 
Num estudo recente, sobre os "sistemas de redes de transações bancárias", Jackeline Silva (2005: 82 e ss.) lista nada menos que 17 "canais eletrônicos" surgidos também a partir da década de 1980, que aumentaram expressivamente as possibilidades de "transações bancárias com os clientes". Podemos dividir estes canais em dois principais grupos: 1) os que conheceram uma difusão expressiva no espaço geográfico, e são de fato a base para a "hipercapilarização" das finanças no território brasileiro; e 2) os que são (ou foram) utilizados de maneira residual no sistema bancário, seja porque são tecnologias consideradas já "ultrapassadas", seja porque os altos custos envolvidos em sua utilização dificultam sua banalização.

Entre os sistemas técnicos deste segundo tipo, poderíamos destacar: 1) Email Banking ${ }^{142}$; 2) Planejador financeiro ${ }^{143}$; 3) Fax $^{144}$; 4) Pager $^{145}$; 5) TV Interativa ${ }^{146}$; 6) WEB TV ${ }^{147}$; 7) Video-Game ${ }^{148}$; 8) Personal Digital Assistant (PDA) ${ }^{149}$; 9) Screenphone (Telefone com Tela) ${ }^{150}$.

142 Este é um canal utilizado pelos bancos para informar os clientes a partir do recebimento de mensagens eletrônicas (emails) por parte destes últimos. Se assemelha muito ao "internet banking", com a especificidade de trazer mais riscos de violação das informações dos clientes, por pessoas indevidas (op. cit.:85).

143 Também uma ferramenta típica do atual período técnico-científico-informacional, o "Planejador financeiro" é na verdade um software "de apoio ao planejamento e controle orçamentário financeiro do cliente"(op. cit.:85).

${ }^{144}$ Este é outro objeto técnico que surge e se banaliza ao mesmo tempo que o próprio processo de automação bancária. Ele possibilita ao cliente ter acesso a informações financeiras na forma impressa em papel. Possui também inconvenientes ligados à falta de segurança na transmissão das informações (a exemplo do que ocorre com as informações passadas via email), com o agravante de que são necessários cuidados adicionais ao "armazenamento e o transporte dos faxes"(SILVA, 2005:87).

145 O canal aberto com os chamados "pagers" (aparelho que somente recebe dados, e não consegue transmitilos a partir do receptor) não possui a eficiência dos demais sistemas técnicos até aqui apresentados. Os "pagers" dependem ainda de centrais de retransmissão de sinais (geralmente sediadas nas grandes cidades), o que diminui também a flexibilidade topológica do sistema.

146 São basicamente três os elementos que compõem este canal de comunicação entre o Banco e seus clientes: a) utilização de um canal de televisão popular; b) um aparelho de TV; e c) os serviços prestados por uma operadora de TV a cabo. Neste canal, estariam disponibilizadas as informações financeiras dos clientes.

${ }^{147}$ Este tipo de sistema técnico se assemelha muito ao sistema de "internet banking", já comentado. Necessita também de alguns objetos técnicos como base para a realização das operações: um aparelho de TV, que deve estar conectado a um aparelho decodificador das informações enviadas pelo Banco (set-top box), uma linha telefônica para a transmissão dos dados, um controle remoto para acionar as funções desejadas, e finalmente um teclado e um browser próprio, para a realização das operações pelo cliente (SILVA, 2005:88).

148 Também é um canal que permite a consulta dos dados financeiros por parte do cliente, através do uso de três principais objetos técnicos: a) um aparelho de TV, b) uma linha telefônica, e c) o cartucho fornecido pela instituição financeira; possui as vantagens da facilidade do acesso às informações, assim como da necessidade de relativamente poucos recursos técnicos para executá-lo. (SILVA, 2005:89).

149 O PDA é um computador portátil, de dimensões reduzidas, para uso pessoal e/ou comercial. Possui geralmente um software próprio, que permite conectá-lo na internet (com linha telefônica, ou através de sistema sem fio), e possibilita a recepção dos dados por parte do cliente, relativos a sua conta e/ou movimentações financeiras. Permite também a execução de algumas operações (não só recepção de dados, portanto).

150 A tradução deste tipo de sistema técnico já indica que além de dados e voz, o canal permite também a transmissão de imagens para o receptor, possibilitando a visualização das informações, que podem ser trabalhadas pelo teclado de seu aparelho. 
Já os canais eletrônicos que de fato contribuíram para a amplificação do poder das redes bancárias no território seriam basicamente os seguintes: 1) os Caixas Eletrônicos (ou "ATM's"151); 2) Pontos de Venda (ou "Points of Sale"); 3) o "Cheque Eletrônico"; 4) Banco por internet; 5) Centrais de Atendimento Telefônico; 6) Wireless Aplication Assistant (WAP); e finalmente 7) os sistemas de transferência eletrônica de dados. Passemos a análise mais circunstanciada de cada um destes sistemas técnicos.

\subsection{Os caixas eletrônicos ou $A T M$ 's}

Implementados no Brasil ainda na década de 1980, os caixas eletrônicos foram utilizados em primeiro lugar dentro das próprias agências bancárias, como forma de desviar a prestação de serviços dos caixas tradicionais. Os sistemas de objetos que compõem este canal eletrônico podem ser assim descritos: "dispositivo eletrônico composto de hardware e software de propriedade da instituição financeira, modem interno, câmeras para rastreamento e monitoramento remoto das funções e transmissão de dados efetuada via WAN (Wide Area Network) ou rede de agência" (SILVA, 2005:90).

Além da função primordial de "saques de numerário", são passíveis de serem realizadas no Caixa Eletrônico as seguintes operações bancárias: a) consultar saldos; b) manejar aplicações financeiras (e ter os resultados impressos, ou exibidos no vídeo); c) transferir valores entre contas e/ou aplicações; d) realizar depósitos; e) imprimir folhas de cheque; f) pagar impostos (como o IPVA, em alguns caixas), entre outras operações. Este conjunto de funções disponibilizadas nos caixas eletrônicos permitiu que Carlos Franco da Silva (1999:60) asseverasse que um terminal deste tipo "funciona como uma miniagência", seja no interior de um "quiosque", nas próprias agências bancárias, ou espalhados pelos estabelecimentos comerciais de mais diversos tipos. Vale ressaltar que antes do período técnico-científico-informacional, a realização destas operações era possível

151 A sigla ATM significa "Automatic Teller Machine", cuja tradução literal seria "máquina dipensadora automática". 
somente dentro das agências bancárias, com a participação direta de um funcionário da instituição.

A evolução das funções dos caixas eletrônicos possui grande significado para a topologia e organização bancária atuais. São dois os principais motivos que nos permitem fazer essa afirmação. Em primeiro lugar, porque esta evolução é resultado direto das disponibilidades técnicas do atual período histórico. O funcionamento dos caixas envolve complexos sistemas técnicos, que fazem circular informações, dados e dinheiro na sua forma monetária. A própria manipulação do papel-moeda e de documentos nos terminais automáticos é possibilitada pela existência de um sistema mecânico e eletrônico que pode emitir cheques, dispensar dinheiro, receber depósitos, entre outras operações típicas de uma casa bancária. Os caixas são, portanto, sistemas técnicos informacionais típicos da atual fase da globalização, onde as variáveis informação, tecnologia bancária e finanças se unem para tornar ainda mais eficaz a circulação de capitais no território.

Uma segunda consideração a respeito da importância dos caixas eletrônicos na organização bancária diz respeito à alteração nas necessidades de mão-de-obra das atividades financeiras. Os $\mathrm{ATM}^{\prime}$ s, por aumentarem sobremaneira a produtividade do atendimento bancário, diminuem a necessidade de funcionários para a prestação dos serviços. Essa automação introduzida por este (e outros sistemas e processos informacionais), "afetam agudamente os níveis de emprego no setor bancário e intensificam o trabalho" neste ramo de atividade, lembra-nos Nise Jinkings $(2002: 124)^{152}$.

Se há uma nova qualidade das características internas do funcionamento do sistema bancário em relação aos $\mathrm{ATM}^{\prime}$ 's, há também mudanças na localização destes

\footnotetext{
152 Segundo ainda a autora, as causas desse desprestígio do fator mão-de-obra em favor das instituições financeiras estão ligadas à evolução das técnicas, mas também às políticas públicas e privadas do setor. Para Nise Jinkings (2002:129), "na segunda metade dos anos 90, o processo intensivo de reorganização do trabalho e de mudança nas estratégias de mercado das instituições bancárias, num contexto de desregulamentação financeira e acirramento da pressão concorrencial no setor, implicou um movimento contínuo de redução do emprego bancário. As medidas governamentais que estimulam as fusões e incorporações entre empresas e desmontam o sistema financeiro estatal conjugam-se à automação e à disseminação de formas flexíveis de organização do trabalho e de contratação nos bancos como fatores de precarização do emprego bancário".
} 
equipamentos, que indicam uma maior capilarização do acesso aos serviços financeiros. Se tomarmos como exemplo a rede de caixas eletrônicos da TECBAN (a chamada rede "24 horas"), vemos que no Brasil inteiro estão espalhados 3.026 terminais deste tipo.

A distribuição regional dos terminais do "Banco 24 horas" estaria assim definida para o ano de 2006:

Tabela 33: Brasil: Distribuição dos Caixas Eletrônicos da Rede "Bancos 24 Horas" (2006)

\begin{tabular}{|l|c|}
\hline \multicolumn{1}{|c|}{ ESTADOS E REGIÃO } & Número de Terminais \\
\hline Alagoas & 25 \\
\hline Bahia & 116 \\
\hline Ceará & 84 \\
\hline Maranhão & 11 \\
\hline Paraíba & 15 \\
\hline Pernambuco & 89 \\
\hline Piauí & 7 \\
\hline R. G. do Norte & 28 \\
\hline Sergipe & 28 \\
\hline NORDESTE & 403 \\
\hline Acre & 0 \\
\hline Amapá & 3 \\
\hline Amazonas & 40 \\
\hline Pará & 45 \\
\hline Rondônia & 1 \\
\hline Roraima & 0 \\
\hline Tocantins & 2 \\
\hline NORTE & 91 \\
\hline Distrito Federal & 60 \\
\hline Goiás & 62 \\
\hline Mato Grosso & 12 \\
\hline Mato G. do Sul & 14 \\
\hline CENTRO-OESTE & 148 \\
\hline Espírito Santo & 94 \\
\hline Minas Gerais & 144 \\
\hline Rio de janeiro & 627 \\
\hline São Paulo & 1.234 \\
\hline SUDESTE & 2.099 \\
\hline Paraná & 122 \\
\hline Rio Gr. do Sul & 121 \\
\hline Santa Catarina & 42 \\
\hline SUL & 285 \\
\hline REGĨ̃O CONCENTRADA & 2.384 \\
\hline TOTAL & 3.026 \\
\hline Foter & \\
\hline
\end{tabular}

Fonte: TECBAN S/A. Sítio da Instituição. 2006. 
Se existe uma maior capilaridade do acesso aos serviços financeiros pela rede do "Banco 24 horas", há que se ressaltar também que esta capilaridade é também bastante seletiva. Cerca de $79 \%$ dos terminais deste tipo estão situados na Região Concentrada. Somente na cidade de São Paulo funcionam nada menos que 504 caixas eletrônicos desta rede, correspondendo a 16,6\% dos totais do território brasileiro. Como mostram os Mapas 11 (município de São Paulo) e 12 (Região Norte do país), a topologia deste canal eletrônico é muito mais densa nas "áreas luminosas" do que nas "áreas opacas" do espaço nacional.

Na Região Norte do País, há apenas 91 terminais instalados, sendo que as cidades de Belém (com 38 Terminais) e Manaus (com 40) concentram nada menos que $85,7 \%$ do total de "Bancos 24 horas" na região. Por isso é possível dizer que a hipercapilaridade que mostra a atual topologia bancária é também seletiva, ao menos em alguns dos tipos de "pontos" da rede.

Quais seriam os conteúdos do território que mais influenciam a distribuição dos ATM's no território brasileiro? Dados da FEBRABAN (que contemplam também a rede do "Banco 24 horas") nos permitem analisar com mais detalhe como se deu a evolução recente da localização dos ATM's, e mostra que a localização deste tipo de "canal eletrônico" depende ainda da topologia bancária "tradicional", isto é, da rede de agências bancárias. 


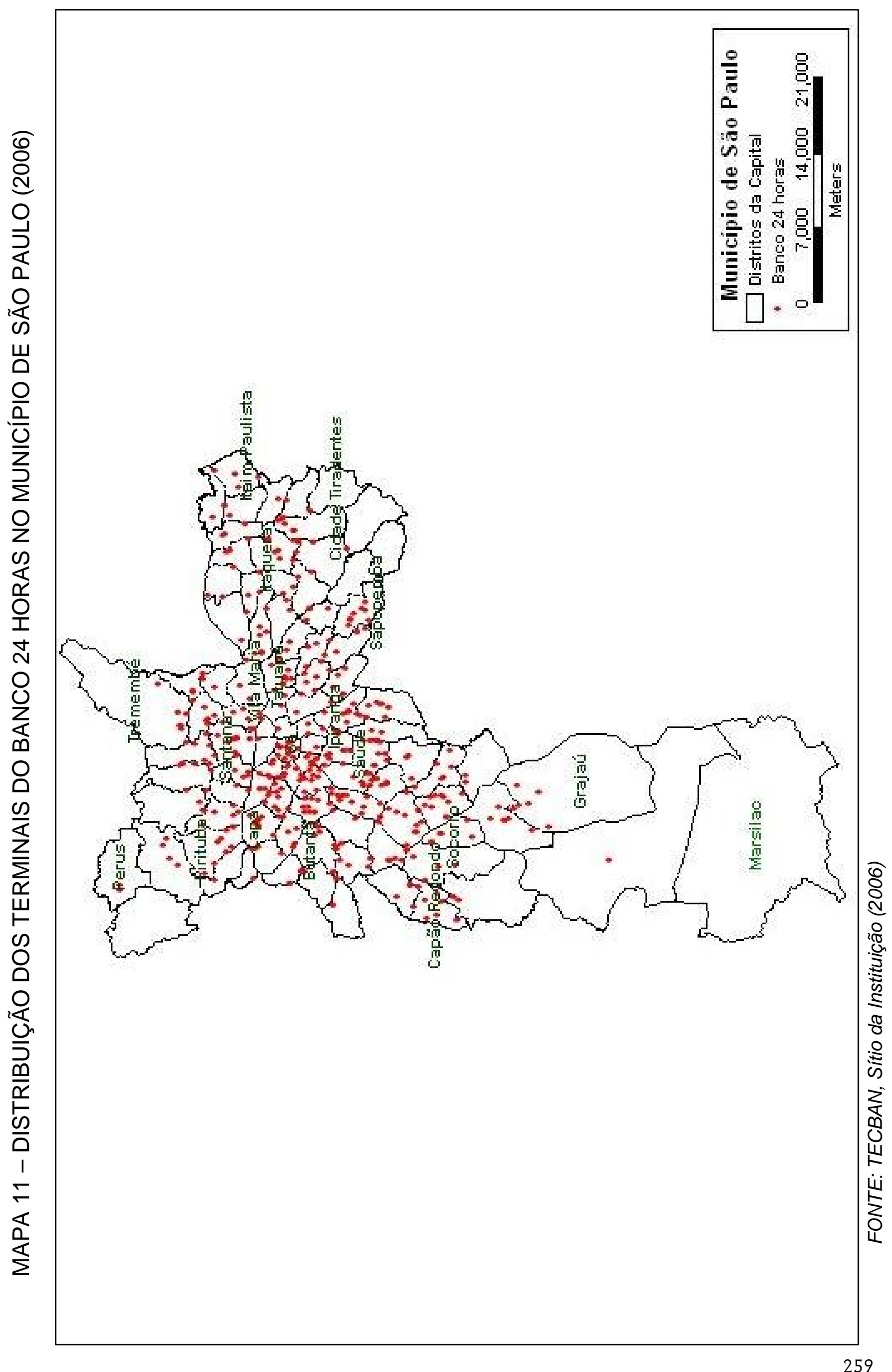




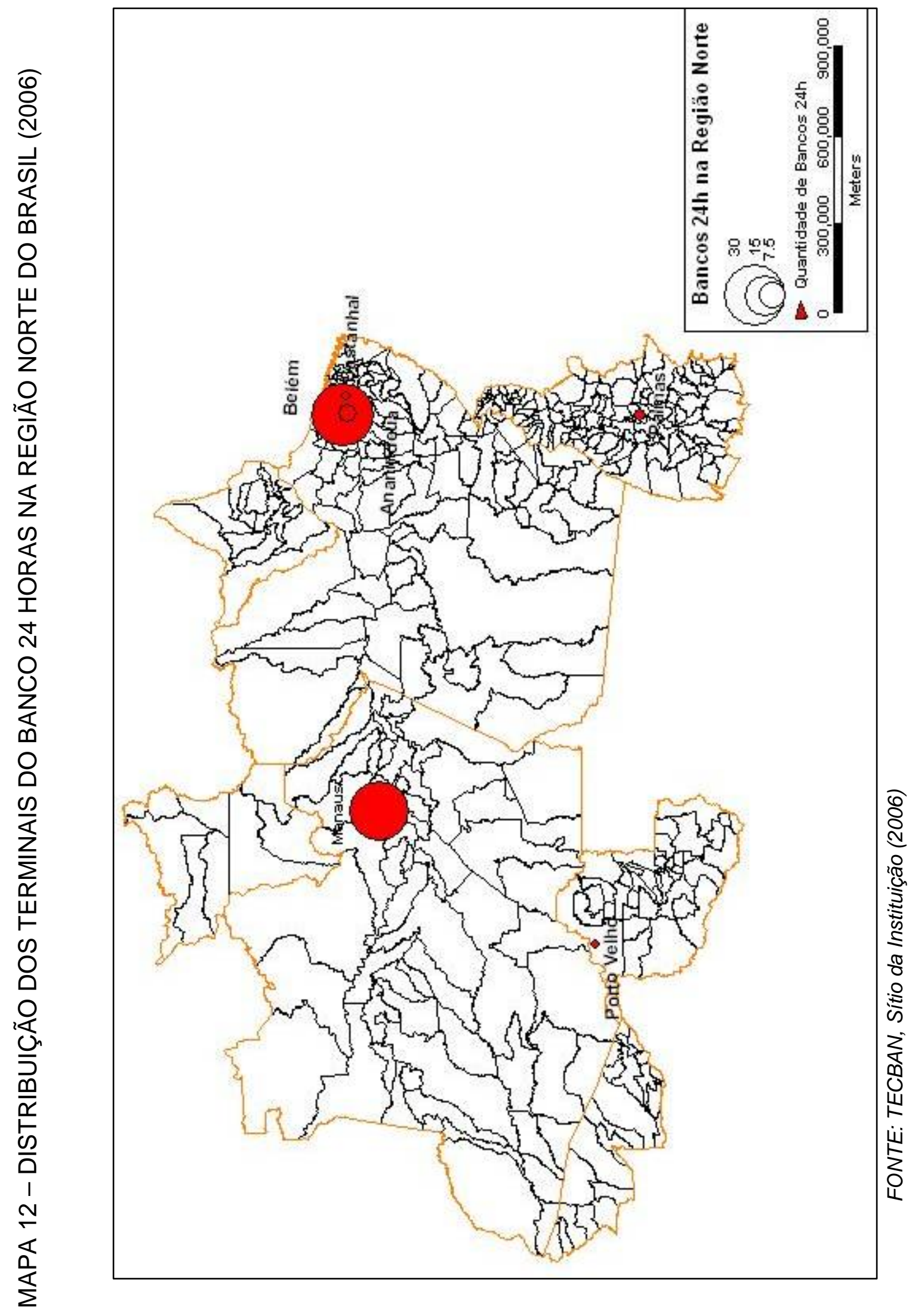


Tabela 34: Brasil: Evolução dos Caixas Eletrônicos Segundo sua Localização Comercial (2000-2005)

\begin{tabular}{|l|c|c|c|c|c|c|}
\hline & 2000 & 2001 & 2002 & 2003 & 2004 & 2005 \\
\hline $\begin{array}{l}\text { Em agências } \\
\text { bancárias }\end{array}$ & 58.462 & 70.921 & 67.654 & 70.046 & 45.401 & 37.767 \\
\hline $\begin{array}{l}\text { Em ante-salas de } \\
\text { auto-atendimento }\end{array}$ & 37.329 & 46.238 & 38.671 & 37.644 & 64.571 & 77.563 \\
\hline $\begin{array}{l}\text { Quiosque em locais } \\
\text { públicos }\end{array}$ & 4.094 & 5.063 & 7.993 & 10.132 & 18.719 & 19.197 \\
\hline $\begin{array}{l}\text { Em postos de } \\
\text { atendimento }\end{array}$ & 8.156 & 9.848 & 10.113 & 10.902 & 12.886 & 15.209 \\
\hline Total & 108.401 & 132.070 & 124.431 & 128.724 & 141.577 & 149.736 \\
\hline
\end{tabular}

Fonte: FEBRABAN. Sítio da Instituição. 2006.

A grande maioria dos Caixas Eletrônicos se encontra dentro das próprias agências bancárias. Estando ali abrigados, são diminuídos largamente os custos para o transporte do dinheiro e a manutenção dos caixas. Concomitantemente, a presença de ATM's aumenta sensivelmente a produtividade do trabalho nas agências, como já tivemos a oportunidade de frisar.

De um total de 95.791 ATM's que se localizavam nas agências no ano de 2000 (cerca de 88,3\% dos totais), passamos em 2005 a contar com 115.330 (cerca de $77,0 \%$ dos totais) dentro, ou na chamada "ante-sala de atendimento". Há uma dupla tendência, neste caso: a) está diminuindo a quantidade relativa de ATM's nas agências; e b) dentro das agências, há uma forte tendência de localizar os ATM's nas "ante-salas" das mesmas, com o objetivo de viabilizar o acesso dos clientes a estas máquinas a qualquer hora do dia, e não somente nos horários comerciais (SILVA, 1999).

De um total de 12.250 ATM's $(11,3 \%)$ que existiam distribuídos "fora das agências" em 2000 (tanto em quiosques, quanto dentro de estabelecimentos comerciais, como mostra a tabela 34), passamos a contar com 34.406 máquinas, perfazendo 22,9\% dos totais. Essa nova localização dos ATM's aumenta, destarte, a acessibilidade física aos serviços bancários por parte dos usuários destes tipos de atividade. 
Tanto Carlos Franco da Silva (1999) quanto Jacqueline Silva (2005) nos chamam a atenção para a importância da nova temporalidade e da maior acessibilidade que a rede de caixas eletrônicos concede aos usuários de serviços bancários, nos centros urbanos nos quais estão instalados. Para Jacqueline Silva (2005:90), “o ATM fica localizado em lugares estratégicos permitindo que os clientes tenham fácil acesso aos serviços disponíveis, além do horário normal de funcionamento público das agências bancárias". Ainda na opinião de Melo, Rios e Gutierrez (2000:50), é necessário destacar que essa "flexibilidade quanto ao local de instalação e ao horário de funcionamento", além "da possibilidade de realizar operações dentro de um carro", são elementos que contribuíram para a grande difusão da rede de ATM's no Brasil ${ }^{153}$.

\subsection{Banco por internet ("Internet Banking") ${ }^{154}$}

Fruto também da expansão dos "serviços telemáticos" que são ofertados para os bancos, "o internet banking é o mais popular canal eletrônico utilizado para tráfego das transações"(SILVA, op. cit::84). Além de apresentar uma "alta capilaridade", segundo destaca a mesma autora, a plataforma da "world wide web" (www) também diminui sensivelmente os custos de transação dos produtos e serviços oferecidos pelos bancos.

Baseando-nos em Albertin (2000) podemos destacar quatro principais fatores que estão na raiz da evolução recente do uso da internet para a realização de transações bancárias:

\footnotetext{
${ }^{153}$ Do ponto de vista de seu funcionamento sistêmico, vale ressaltar que a rede de quiosques dos bancos (sejam eles quiosques das próprias instituições bancárias ou da rede Banco 24 horas) está diretamente conectada com os computadores centrais das instituições financeiras. Esta conexão instantânea é que permite validar (ou não) as milhares de transações que são requisitadas diariamente na rede. Através de mecanismos on-line, também são acionados os serviços de manutenção da rede de terminais. A manutenção executa operações como: troca de bobinas de papel dos ATM's, reposição de notas de dinheiro, problemas com cartões de cliente etc., como nos relatou em entrevista o engenheiro José Nitta Sala.

${ }^{154}$ Este tipo de serviço é também distinguido na literatura especializada como "Home Banking"(ALBERTIN, 2000:31). SILVA (2005), porém, faz a distinção entre o internet banking e o home banking pois este último requer, por parte do usuário, a instalação de um software específico (fornecido pela instituição bancária), para a realização das operações. O Internet banking, por seu turno, utilizaria "serviços on-line" para o procedimento das transações bancárias.
} 
1) há um aumento da "curva de aprendizado dos usuários de serviços bancários", que estão cada vez mais habilitados no uso dos microcomputadores;

2) há um aumento do conhecimento - por parte dos clientes - da possibilidade de realização de operações bancárias por meio desta rede de computadores; este conhecimento, por seu turno, deriva das maciças campanhas publicitárias que os Bancos realizam na mídia impressa e televisionada;

3) o número de computadores passíveis de serem conectados à internet cresce em níveis expressivos no território;

4) há uma irrefreável busca, por parte do sistema bancário, de soluções para “a redução do custo do processamento das transações"(ALBERTIN, 2000:30).

Para nos aproximarmos do que significa esta diminuição de custos proporcionada pelo uso da internet, podemos num primeiro momento comparar os valores envolvidos nas transações "informacionais" (realizadas pela rede $w w W$ ) com aquelas que poderíamos chamar de "mecânicas" (realizadas por cartas e/ou telefone). O quadro a seguir nos dá uma dimensão mais aproximada destes custos:

Quadro 9: Comparação dos Custos de Transação Bancária, por Carta, Telefone e Internet

\begin{tabular}{|l|r|r|}
\hline Tipo de Processo & \multicolumn{1}{c|}{$\begin{array}{c}\text { Custo Unitário } \\
\text { (US\$) }\end{array}$} & \multicolumn{1}{c|}{$\begin{array}{c}\text { Custo Unitário } \\
\text { (índice 100) }\end{array}$} \\
\hline Carta & 8,30 & 451 \\
\hline Telefone & 1,84 & 50 \\
\hline Internet & 0,92 & 10 \\
\hline $\begin{array}{l}\text { Consulta que exige a resposta do agente ao } \\
\text { cliente }\end{array}$ & 0,18 & 5 \\
\hline $\begin{array}{l}\text { Resposta automatizada a consulta sobre uma } \\
\text { fatura, com intervenção ocasional do operador }\end{array}$ & 0,09 & 5 \\
\hline $\begin{array}{l}\text { Resposta a consulta sobre fatura totalmente } \\
\text { automatizada }\end{array}$ & 0 \\
\hline
\end{tabular}

Fonte: SILVA, Jackeline (2005:84)

Há clara vantagem em termos de custos com a utilização deste que seria o canal técnico-científico-informacional, representado no quadro acima: a internet. Tanto pela comparação através do "índice 100", quanto pelos valores envolvidos na 
utilização de cada canal, vê-se que a evolução das finanças está intimamente ligada ao desenvolvimento das técnicas informacionais. Os gastos decrescem quanto mais são utilizados os meios eletroeletrônicos que, no caso, são quase sinônimo de "ausência de trabalhadores" envolvidos. Significa dizer que estes sistemas técnicoinformacionais contribuem para a diminuição da utilização de mão-de-obra nas instituições financeiras, já que estas possuem cada vez mais um elevado grau de composição técnica de sua estrutura de capital ${ }^{155}$.

Também o estudo de Melo, Rios e Gutierrez (2000) indica que há um aumento da utilização destes sistemas informacionais ("internet banking" e "home banking"), e que a utilização destes canais possui dois fins básicos: a) aumentar a acessibilidade dos clientes aos circuitos financeiros; e b) diminuir os custos das transações. Segundo a análise dos autores, diferentes sistemas técnicos encarecem ou diminuem os gastos das instituições bancárias com sua rede-suporte de prestação de serviços.

Quadro 10: Brasil: Evolução dos Custos das Operações por Sistema Técnico Utilizado (2000)

\begin{tabular}{|l|c|}
\hline SISTEMA TÉCNICO & US\$ \\
\hline Na Agência & 1,07 \\
\hline Por telefone & 0,54 \\
\hline Em Caixa Eletrônico & 0,27 \\
\hline Via Home Banking & 0,15 \\
\hline Via Internet & 0,10 \\
\hline
\end{tabular}

Fonte: Elaboração própria a partir de Melo, Rios e Gutierrez(2000:55)

Vale destacar que o incremento do uso da rede internet por parte das instituições financeiras tem relação direta com a instalação do novo Sistema de Pagamentos Brasileiro, no ano de 2002. Por ter aumentado a segurança das transações e diminuído o tempo de sua realização, os novos padrões de funcionamento do Sistema de Pagamentos “deram grande contribuição para o avanço da internet

155 O estudo da relação entre a modernização tecnológica e o desemprego bancário é um tema bastante importante para a relação do espaço com as finanças. Por se constituir num universo que mereceria um estudo em separado, decidiu-se apenas por indicar a questão na presente parte da tese. Para uma análise crítica do processo, ver Nise Jinkings (2002). O estudo da empresa de consultoria Mackinsey \& Company (MCKINSEY, 1999: capítulo 2) traz uma análise mais voltada para as vicissitudes do mercado para o mesmo tema. 
bancária"(GAZETA MERCANTIL, 01/004/2003). As técnicas informacionais, mais uma vez, se mostram bastante convergentes com o fenômeno da prestação de serviços bancários.

\subsection{Centrais de atendimento telefônico ("Call-Centers")}

Este é um canal de comunicação cuja difusão está diretamente ligada à expansão da rede de telefonia do território brasileiro. Apesar de sua utilização ser anterior ao processo de automação bancária iniciado na década de 1980, houve um incremento da participação deste sistema técnico como canal de transação bancária na década de 1990, e hoje faz parte não só da realidade das instituições financeiras, mas também de vários outros tipos de empresas comerciais.

Se o uso da telefonia em sua forma "tradicional" (com a intervenção manual de um atendente, para captar e operar as transações com o cliente) já é realizado há mais tempo, a novidade do atual período histórico é a operação do canal telefônico através de formas "automáticas". "Através de recursos eletrônicos utilizados", lembra-nos Jacqueline Silva $(2005: 86)$, “(...) como a chamada URA (Unidade de Resposta Audível), é possível mapear e tratar a solicitação de transação do cliente e encaminhá-la para o processamento, e o recurso de reconhecimento de voz que faz o mesmo processo".

A utilização das técnicas da informação na prestação de serviços bancários por telefone, portanto, alterou também as possibilidades de uso deste sistema técnico, de duas principais formas:

a) o processo "manual" de atendimento tende a ser cada vez mais substituído pelo "automático", dada a evolução das tecnologias disponíveis para este tipo de sistema técnico; boa parte das operações demandadas são liquidadas sem a interferência da ação humana direta; e

b) há também uma tendência de formação de "centrais de atendimento" (os "callcenters") por parte das empresas bancárias, já que a escala de atendimento é cada 
vez maior, e muitas vezes a formação (ou a contratação terceirizada) de equipes especializadas para este canal é mais barata e eficiente para os bancos, em vários tipos de operações ${ }^{156}$.

No que tange à acessibilidade dos serviços bancários, pode-se dizer que a utilização de centrais de atendimento eletrônicas é também um fator de ampliação da capilaridade do sistema financeiro no território. A incorporação da rede telefônica de forma sistemática à rede de prestação de serviços financeiros permite que praticamente todo o território nacional esteja ao alcance do poder das redes bancárias, já que o uso de telefones (tanto móveis quanto fixos) é um dado também bastante banalizado no espaço nacional.

\subsection{Demais tipos de canais eletrônicos}

Podemos listar ainda quatro "canais eletrônicos financeiros", que se configuram como importantes extensores da ação das instituições financeiras no território brasileiro. São eles: a) os Pontos de Venda; b) o chamado "Cheque Eletrônico", c) os canais "sem fio", ou Wireless Aplication Assistant (WAP) e finalmente d) o Eletronic Data Interchange (EDI). Passemos a descrição mais detalhada de cada um destes novos sistemas técnicos.

\section{a) Pontos de Venda ou "Points of Sale" (POS)}

Também conhecidos como "points of sale", o Ponto de Venda (ou PDV's), constitui-se num sistema técnico que permite que grandes estabelecimentos comerciais possam se comunicar com as administradoras de cartões de crédito, que aprovam (ou não) quase que instantaneamente as operações de vendas para seus clientes. De maneira sucinta, podemos assim descrever os objetos técnicos envolvidos neste sistema: "equipamentos de POS, algum tipo de linha para

156 Como nos lembra Adriana Bernardes (2001:138), as centrais de atendimento são também um fenômeno típico das "possibilidades abertas pela informatização" das atividades de serviços, e servem principalmente às grandes firmas nacionais, assim como às empresas globais aqui instaladas (BERNARDES, 2001:138-139). 
comunicação de dados, acesso às administradoras de cartão de crédito e um cartão de crédito ou débito do cliente"(SILVA, 2005:91).

Os terminais deste tipo estão na base de uma mudança recente, ocorrida em grandes lojas de departamentos e supermercados. Muitos destes sistemas de ações comerciais passaram a contar com suas próprias instituições financeiras, após a adoção deste novo "canal de comunicação" com os clientes. Alguns estabelecimentos comerciais (como é o caso da rede C $\& 2 A$ no Brasil) constituíram seus próprios bancos, após a banalização dos "Pontos de Venda" e dos cartões de crédito "próprios", com sua rede de clientes.

\section{b) Cheque Eletrônico}

Semelhante ao sistema de "Pontos de Venda", o cheque eletrônico é um instrumento de "automação comercial" recente, que interliga os estabelecimentos comerciais diretamente às instituições financeiras. Assim, "permite efetuar transações comerciais eletrônicas, onde as compras efetuadas pelo comprador são debitadas automaticamente de sua conta bancária (conforme a especificação da forma de pagamento) e creditadas na conta do vendedor"(SILVA, 2005:91).

A Empresa Tecnologia Bancária (TECBAN S/A) é uma empresa que disponibiliza esse tipo de "canal eletrônico" (assim como boa parte das instituições bancárias), com três principais "focos": a) instituições financeiras; b) empresas; e c) pessoa física. Nos três sistemas, o que ocorre é a possibilidade de "transferência eletrônica de fundos" (TEF), isto é: realizar pagamentos sem a utilização do chamado "cheque-papel", ou cheque convencional.

\section{c) Wireless Aplication Assistant (WAP)}

A WAP pode ser considerada como um sistema técnico-informacional que permite uma comunicação entre dois atores envolvidos numa operação financeira sem o uso de fios. Antes do período técnico-científico-informacional, todas as transações financeiras necessitavam de uma rede-suporte física, que transmitisse as 
informações (cliente-banco ou banco-cliente) através de objetos e sistemas técnicos materiais. Estes novos sistemas possibilitam que o uso de computadores pessoais, terminais de agências e correspondentes esteja diretamente conectado com as instituições financeiras independentemente de ligações físicas entre os terminais. É necessário, porém, que cada terminal esteja operando dentro da área abrangida pelo sistema central que emite e recebe as ondas na freqüência que o sistema WAP esteja funcionando.

No caso de operações de clientes com seus bancos, a tecnologia WAP permite ainda que os aparelhos telefônicos celulares sejam utilizados para a troca de informações financeiras. Atualmente, através do processo que se convencionou chamar de "convergência tecnológica", é possível a manipulação/transmissão de dados, voz, e até imagens, com aparelhos de telefonia celular mais modernos. Este novo canal ganhou o nome de "mobile banking", lembra-nos Jackeline Silva, e com ele, "os bancos são capazes de prover serviços bancários 24 horas de forma móvel ao cliente, agregando mais comodidade e qualidade"(SILVA, 2005:87) aos serviços.

\section{d) Eletronic Data Interchange (EDI) e Web Electronic Data Interchange (WEB-EDI)}

Conhecido também como "intercâmbio eletrônico de documentos", esse serviço é bastante utilizado na relação dos bancos com grandes clientes, isto é, pessoas jurídicas. Apesar de utilizarem a rede de internet, as mensagens trafegadas por este tipo de "intercâmbio" possuem formatos específicos, de acordo com cada necessidade comercial. Além de se constituir num serviço eminentemente corporativo (já que permite a concretização de operações empresariais/financeiras de vários tipos), pode ser também considerado um serviço que diminui ainda mais o fluxo de papéis e documentos entre os atores envolvidos. Daí ser mais uma tecnologia informacional, que acelera a velocidade de circulação dos dados bancários no território, contribuindo para a hegemonização do sistema bancário no conjunto das atividades produtivas no país. 
Estes são, em linhas gerais, os sistemas técnicos que permitiram que as redes de prestação de serviços financeiros pulverizassem ainda mais as ações bancárias no espaço geográfico. Essa pulverização, vale ressaltar, se dá com muito mais força nos centros urbanos, já que nestes pontos do território é que encontramos as maiores densidades de população, de empresas, de autarquias governamentais etc., sendo assim pontos de maior geração e consumo de informações bancárias.

Ao menos potencialmente não há limites para a quantidade de informações e recursos que podem ser transitados pelos "canais eletrônicos" financeiros. Em seu uso concreto, porém, duas são as grandes limitações para sua utilização: a conectividade ("reliability") do sistema e a segurança da rede.

Por seu turno, a eficácia da conectividade dos canais eletrônicos tem duas principais limitações: ela depende tanto da distribuição dos pontos de contato dos canais (terminais de cartão de crédito, computadores pessoais, telefones etc.) quanto das diferenças normativas entre os países. Havendo uma rede capilarizada de pontos de recepção/transmissão de dados bancários, assim como certa homogeneidade normativa entre os canais eletrônicos de cada país, a fluidez e a eficácia deste meio de troca de informações é tornada ainda mais performática; a ação dos bancos, portanto, se faz também mais invasora, mais onipresente.

Mas, de todo modo, apesar deste "potencial invasor" das técnicas financeiras, que permite uma "hipercapilarização" do acesso às operações financeiras, os canais dependem ainda dos conteúdos do território e da topologia física dos pontos de sua rede para funcionarem. Não há ações que se dão sem objetos, assim como os objetos só ganham existência (ou funcionalidade) quando acionados por determinado ator. A distribuição dos sistemas técnicos no território, portanto, é um dos fatores que modulam a capilaridade do acesso às finanças. 


\section{CAPítulO 12. Aspectos Locais da Evolução Recente do Fenômeno do Crédito}

Na história da análise do fenômeno urbano, várias foram as propostas teóricas que chamaram a atenção para a importância das finanças, principalmente em sua relação com a vida nas cidades. Lewis Mumford $(1961,1998: 578)$ já notara, em seu livro A Cidade na História, que a vida nas metrópoles envolvia necessariamente a realização de "seguros", a difusão da "publicidade" e a utilização das "finanças" para seu desenvolvimento ${ }^{157}$.

Recentemente, Andrew Leyshow e Nigel Trifth [1997:280) nos lembram que é nas cidades do centro do sistema capitalista (mormente Londres, Nova lorque e Tóquio) que as instituições financeiras e os grandes bancos definem os caminhos principais dos "fluxos financeiros espaciais" ${ }^{158}$. Nelas são desenvolvidos também novos produtos financeiros, que aceleram sobremaneira as velocidades de circulação do capital. Como nos aproximar, a partir destes esforços teóricos já empreendidos, das formas atuais de imbricação entre o fenômeno das finanças e a vida urbana? Quais as especificidades, e os exemplos possíveis de serem trabalhados na relação dos circuitos financeiros com a vida nas cidades brasileiras?

Uma primeira resposta para estas perguntas diz respeito ao aumento do número de contas-corrente abertas no sistema bancário brasileiro. Este fenômeno mostra que houve incremento do número de pessoas passíveis de fazerem parte da rede de fixos e fluxos do sistema financeiro brasileiro de forma direta.

\footnotetext{
157 Esta seria a "nova trindade que dominou a cena metropolitana", assevera Mumford (1961, 1998:578). A coordenação de atividades ligadas à realização de seguros, da publicidade e das finanças permitiu que as metrópoles adquirissem um tamanho em extensão e em contingente populacional nunca antes visto na história do urbanismo. Conseqüência disto, o aumento do poder dos bancos na metrópole foi tão expressivo, "que, mais cedo ou mais tarde, grande parte da população, sob a forma de investidores, depositantes mutuários, especuladores, foi atraída para o esquema metropolitano"(MUMFORD, 1961, 1998:578/579).

158 Uma análise inicial da ação dos bancos estrangeiros como "agentes urbanos" no Brasil pode ser encontrada em Videira (2005).
} 
Tabela 35: Brasil: Evolução Recente do Número de Contas-corrente e Poupança (19992005)

\begin{tabular}{|c|c|c|c|c|c|c|c|}
\hline & 1999 & 2000 & 2001 & 2002 & 2003 & 2004 & 2005 \\
\hline $\begin{array}{l}\text { No. de contas-corrente } \\
\text { (milhões) }\end{array}$ & 49,9 & 63,7 & 71,5 & 77,3 & 87,0 & 90,2 & 95,1 \\
\hline $\begin{array}{l}\text { Clientes de poupança } \\
\text { (milhões) }\end{array}$ & 41,6 & 45,8 & 51,2 & 58,2 & 62,4 & 67,9 & 70,8 \\
\hline População (milhões) & 167,9 & 170,1 & 172,3 & 174,6 & 176,8 & 179,1 & 181,3 \\
\hline $\begin{array}{l}\text { No. de contas-corrente } \\
\text { por população }\end{array}$ & 3,36 & 2,6 & 2,4 & 2,2 & 2,0 & 1,9 & 1,9 \\
\hline
\end{tabular}

Fonte: Elaboração própria a partir de dados da FEBRABAN - Relatórios Sociais $(2001,2006)$; IBGE. Estimativa Populacional (vários anos).

O aumento expressivo do número de contas bancárias no País parece ser o dado mais expressivo da tabela. Entre os anos de 1999 e 2005, houve um crescimento de pouco mais de $90 \%$ no número de contas-corrente no país. O crescimento das poupanças também foi bastante significativo: cerca de 70\%, para o mesmo período.

O índice de contas-corrente por população também demonstra que ocorrera um aumento significativo do alcance da bancarização no território. Pode-se dizer que no Brasil, de uma média de uma conta bancária para cada 3,36 habitantes em 1999, passamos a uma conta para cada 1,9 habitante. Portanto, uma difusão significativa do fenômeno.

O que necessita ser ainda lembrado é que a abertura de uma conta-corrente é a ligação necessária para que um agente (seja ele uma pessoa física ou jurídica) tenha acesso a todos os tipos de produtos oferecidos pelas instituições financeiras: seguros, pagamentos via eletrônica ( $D O C^{\prime}$ s), empréstimos etc.

Em relação à prestação destes serviços bancários, a operação que mais tem chamado a atenção dos geógrafos - e que influencia a vida das populações urbanas com mais profundidade - é a concessão de créditos. O fenômeno da concessão de créditos vem há algum tempo sendo estudado pelos geógrafos. Milton Santos, já na 
década de 1970, afirmava que o crédito era um fenômeno essencial para o entendimento do funcionamento das cidades. Para o autor (SANTOS, 1979:180), "o crédito é indispensável, tanto para os agentes, como para os consumidores. Para os primeiros, em geral, é única possibilidade de ingressar ou de se manter em atividade. Para os segundos, o crédito representa a possibilidade de acesso ao consumo, mesmo que não tenham renda fixa".

Em função deste quadro de uma hipercapilarização do acesso ao serviços bancários, de aumento expressivo de contas-corrente bancárias no território, quais as mudanças que ocorreram também com o fenômeno do crédito? Numa palavra: quais as modalidades de creditização do território que interferem com mais vigor na reprodução da vida urbana atual?

\subsection{Novos produtos financeiros e o crédito para pessoas físicas}

Em seu aspecto mais geral, o fenômeno do crédito pode ser considerado como um atributo típico da sociedade capitalista. Como anotara Rudolf Hilferding (1909, 1985:74) em seu estudo clássico, “a expansão do crédito torna possível (...) um rápido crescimento da circulação, maior que a possível com base no dinheiro metálico". Reconciliando as diferentes temporalidades da produção e da circulação, o crédito aumenta a velocidade das transformações na sociedade capitalista. "O crédito acelera tudo", lembra-nos ainda Paul Singer (2000:30).

Se o crédito possui relação direta com as diferentes temporalidades do processo produtivo, ele também interfere sensivelmente na organização espacial destas mesmas atividades produtivas. A utilização do crédito permite, destarte, tanto uma adequação dos tempos da produção, quanto da distribuição territorial da riqueza. Daí sua importância na organização do espaço e da economia de qualquer país.

A análise do fenômeno recente do crédito no território brasileiro mostrou que a aceleração de sua concessão vem se dando muito mais para as "pessoas físicas" do 
que para "pessoas jurídicas". Isto é, de um sistema de concessões baseado em empresas e instituições, vemos que paulatinamente o chamado "crédito pessoal" vem tomando dimensões maiores. Como mostra a tabela 36, abaixo:

Tabela 36: Brasil: Evolução Recente do Volume de Créditos Livres ${ }^{159}$ (em R\$ milhões) (2003-2005)

\begin{tabular}{|l|r|r|r|}
\hline & 2003 & 2004 & 2005 \\
\hline Pessoa Física & 101.003 & 138.548 & 190.731 \\
\hline Pessoa Jurídica & 154.636 & 180.248 & 213.055 \\
\hline Total & 255.638 & 318.796 & 403.786 \\
\hline
\end{tabular}

Fonte: FEBRABAN. Portal de Informaçóes. Módulo 1 - Crédito. s/d.

Se de um lado, portanto, o sistema de crédito aumenta expressivamente sua magnitude recentemente, ele aumenta ainda de maneira mais pronunciada para o circuito das pessoas físicas, tomadoras de crédito. No ano de 2003, as pessoas físicas absorveram $39,5 \%$ dos totais de créditos, e esta proporção é incrementada para $47,2 \%$ dos totais, no ano de 2005 . Significa dizer que atualmente quase a metade dos empréstimos é concedida para indivíduos, alterando um fluxo que normalmente era monopolizado por empresas e autarquias estatais. Entre 2004 e 2005, como mostra a tabela 36, o ritmo do crescimento dos empréstimos é também maior para as pessoas físicas: estes créditos cresceram $37,7 \%$, enquanto os créditos para pessoas jurídicas aumentaram $18,5 \%$.

Se circunscrevermos ainda mais a variável "crédito para pessoas físicas", vemos que certos tipos de créditos crescem com mais vigor do que outros. Segundo as estatísticas da FEBRABAN, são basicamente 10 os tipos de operações realizadas por pessoa física, junto ao sistema financeiro e bancário brasileiro: a) Cheque especial; b) Crédito pessoal; c) Crédito consignado; d) Financiamento Imobiliário; e) Financiamento de Veículos; f) Financiamento de bens; g) Cartão de crédito; h)

\footnotetext{
159 Os chamados "créditos livres" são aqueles que não têm uma contrapartida em relação ao emprego dos capitais; podem ser gastos de acordo com as necessidades do tomador do crédito. A outra grande tipologia da concessão são os chamados "créditos direcionados", que têm geralmente ligação com projetos de desenvolvimento, com um "consumo produtivo" (e não "consumptivo", como é o caso do crédito pessoal). As principais formas de "crédito direcionado" são os créditos para a Habitação, a maior parte do Crédito Rural, assim como os empréstimos do BNDES (FEBRABAN, 2006).
} 
Operações de leasing; i) Crédito fornecido por cooperativas; e j) Outras operações $^{160}$.

Dada esta classificação, podemos proceder à análise da evolução recente destas operações de crédito, que se comportou da seguinte maneira:

Tabela 37: Brasil: Evolução dos Créditos com Recursos Livres para Pessoas Físicas (em R\$ milhões) (2004-2006)

\begin{tabular}{|l|r|r|r|}
\hline & \multicolumn{1}{|c|}{$\begin{array}{c}\text { Janeiro de } \\
\mathbf{2 0 0 4}\end{array}$} & \multicolumn{1}{c|}{$\begin{array}{c}\text { Janeiro de } \\
\mathbf{2 0 0 5}\end{array}$} & \multicolumn{1}{c|}{$\begin{array}{c}\text { Janeiro de } \\
\mathbf{2 0 0 6}\end{array}$} \\
\hline Cheque especial & 9.355 & 10.567 & 12.232 \\
\hline Crédito pessoal & 21.149 & 25.833 & 31.340 \\
\hline Crédito consignado & 9.696 & 18.948 & 33.670 \\
\hline Financiamento imobiliário & 1.380 & 1.076 & 900 \\
\hline Financiamento de veículos & 30.619 & 38.855 & 51.938 \\
\hline Financiamento de bens & 5.360 & 7.375 & 10.241 \\
\hline Cartão de crédito & 6.657 & 8.711 & 11.882 \\
\hline Leasing & 1.718 & 4.395 & 8.635 \\
\hline Cooperativas & 5.296 & 7.133 & 8.440 \\
\hline Outras operações & 11.109 & 19.713 & 25.717 \\
\hline TOTAL PESSOA FíSICA & 101.003 & 134.551 & 186.867 \\
\hline
\end{tabular}

Fonte: FEBRABAN. Portal de Informaçôes. Módulo 1 - Crédito. s/d.

Conforme frisamos, o volume de créditos para pessoas físicas quase dobrou no Brasil, nos dois últimos anos. Mas há modalidades de concessão de crédito que conhecem neste período um crescimento vertiginoso. É o caso, por exemplo:

a) Leasing: principalmente por ser - assim como o crédito consignado - um tipo de crédito com uma segurança jurídica maior, conheceu recentemente um incremento expressivo no país; somente para o período 2004/2005, o aumento foi de cerca de 102,1\%;

b) Crédito consignado: concedido principalmente por bancos e financeiras, este modelo de "desconto em folha de pagamento" também teve crescimento expressivo de sua utilização nos meios urbanos brasileiros: de 2004 a 2006, aumentou em nada menos que $247 \%$ esta modalidade de concessão de crédito no País;

\footnotetext{
${ }^{160}$ Entre as "outras operações", estão modalidades como o "adiantamento a depositantes", "renegociação de dívidas", "desconto de cheques e de recebíveis", entre outras.
} 
c) Financiamento de veículos: chama nossa atenção também, em primeiro lugar, por se constituir o tipo de crédito que mobiliza a maior quantidade de recursos "individualmente": esta modalidade respondeu por 30,3\% dos totais dos créditos pessoais em 2004, 28,8\% em 2005 e finalmente 27,8\% em (janeiro de) 2006; e se mostrou importante também por sua variação ao longo do período indicado na tabela: entre 2004/2006, tem um incremento da ordem de $69,6 \%$.

Todos os tipos de crédito se avolumam em níveis bastante significativos, e movem o sistema bancário brasileiro para o aprimoramento de seu fornecimento. Também segundo os dados da FEBRABAN, entre 2004 e 2005, o crédito concedido através de cheque especial cresce 10\%; o crédito pessoal (excluído o consignado), aumenta $11 \%$. Já no financiamento de bens duráveis, o crescimento é de $35 \%$. Com o crédito operacionalizado através do uso de "cartões de crédito", ocorre ainda um aumento significativo de $58 \%$ em sua concessão.

Esta é uma nova realidade que coincide também com a nova topologia do sistema bancário brasileiro: como vimos, há uma nova tipologia de fixos geográficos sendo instalada no território, que tem contribuído para diminuir os custos bancários, mas talvez principalmente para tornar mais acessível a todos os sistemas de ação urbanos, esses produtos típicos do sistema bancário contemporâneo.

O fenômeno do crédito pessoal nos pareceu ter seu incremento vinculado a esta nova geografia bancária que se instala. Essa topologia, menos dependente das agências, mais estruturada em sistemas de objetos próximos aos circuitos comerciais e produtivos, é que acaba por aumentar a quantidade de pessoas utilizadoras destes circuitos, como ajuda ainda a aumentar os volumes e as velocidades da circulação de capitais no território. 


\subsection{A hipercapilaridade e os objetos técnicos: o uso dos cartões de crédito}

A vida urbana é uma vida eminentemente baseada na utilização de objetos técnicos de toda sorte. Georges Friedmann (1968:11), em outro contexto histórico, assinalava já que "o citadino, ao longo de seu dia, não faz outra coisa senão deixar uma máquina para pegar outra". O que dizer desta frase de Friedmann no atual período, em que vivemos num mundo informacional, onde a "aceleração contemporânea" coloca à disposição desta população urbana uma quantidade inaudita de novos objetos e sistemas técnicos?

Os novos objetos técnicos, criados com intencionalidades cada vez mais precisas, interferem sensivelmente no cotidiano das pessoas, seja em suas relações produtivas, domésticas, pessoais, de transporte etc.

Há, porém, objetos que são mais ou menos "funcionais" ao sistema do qual fazem parte (BAUDRILLARD, 1968, 1993). Atualmente, podemos falar de objetos dotados de "extrema intencionalidade" (SANTOS, 1996:145), que aumentam o grau de racionalidade do ambiente do qual fazem parte, e acabam por limitar o escopo da ação dos atores que os utilizam, segundo um conjunto de procedimentos predeterminados. Os objetos técnicos que detêm esta hipertelia (SIMONDON, 1958, 1989) ${ }^{161}$, influenciam o comportamento humano nas cidades por vários fatores: seja pelo conforto que trazem, pelo status social que conferem ao seu possuidor, ou simplesmente pela extremada eficácia de seu desempenho. Um exemplo deste novo tipo de objeto técnico são os cartóes de crédito.

Os cartões de crédito podem ser considerados como uma manifestação bem acabada do atual período técnico-científico-informacional; por isso sua banalização recente ter sido tão expressiva. Essa afirmação é passível de ser feita, em primeiro

161 Segundo a definição de Simondon $(1958,1989: 50)$, “a evolução dos objetos técnicos manifesta fenômenos de hipertelia que dão a cada objeto uma especialização exagerada e os desadaptam (désadaptent) em relação a uma mudança mesmo leve, sobrevindo (survenant) das condições de utilização ou de fabricação". 
lugar, pois os cartões de crédito (assim como as empresas que os gerenciam) têm como uma das suas matérias-primas a variável informação. Tanto as informações pessoais sobre os próprios usuários dos cartões (dados pessoais, sócioeconômicos, financeiros), quanto as informações sobre a movimentação mensal destes agentes, a partir do uso do cartão. Como nos lembra Adriana Bernardes (2001:131), "os dados pessoais das empresas e dos clientes conformam gigantescos bancos de informações manipulados com fins mercadológicos", e através da manipulação destas informações é possível que o usuário se integre numa complexa rede de operações financeiras, de alcance globalizado.

Mas não só por se constituir num objeto informacional é que os cartões são objetos bastante contemporâneos ao atual período; também por sua influência na prática do consumo. Os cartões de crédito podem ser ainda considerados como um elemento técnico que potencializa sobremaneira o fenômeno do consumo, já que antecipam recursos financeiros ao seu usuário, cobrando tanto uma determinada taxa de juros, como o serviço prestado pela administração dos sistemas técnicos que permitem sua utilização.

Por último, mas não menos importante, a difusão de seu uso está também diretamente relacionada à profusão de campanhas publicitárias de vários tipos, através das várias formas de mídia (televisiva, impressa, outdoors, via internet etc.). A força desse arranjo entre novos sistemas de objetos, publicidade e crédito leva ao que o sociólogo Jean Braudrillard (1968, 1994:169-170) denominou de "coerção da compra". Para o autor (1968, 1994:169-170), “o consumidor moderno assume espontaneamente esta obrigação sem fim: comprar a fim de que a sociedade continue a produzir, a fim de se poder pagar aquilo que foi comprado"162.

\footnotetext{
${ }^{162}$ Especificamente com relação ao crédito e à publicidade, assevera o autor ainda que "a virtude do crédito (como da publicidade) é com efeito o desdobramento da compra e de suas determinações objetivas. Comprar a crédito equivale à apropriação total de um objeto por uma fração do seu valor real" (...) "Um investimento mínimo para um lucro grandioso", ironiza Baudrillard $(1968,1994: 170)$.
} 
Apesar de terem sido introduzidos no Brasil ainda no ano de 1956, sua utilização permaneceu bastante restrita durante quase quatro décadas. Foi necessária a expansão do meio técnico-científico-informacional - principalmente nas cidades brasileiras - para que sua utilização também se expandisse. Como todos os demais objetos informacionais, possuem uma vida eminentemente sistêmica. Basta lembrarmos que para seu funcionamento, eles dependem ainda dos seguintes sistemas técnicos: redes de telefonia, terminais de recebimento, pontos-de-venda, caixas-automáticos etc. Mas não só estes sistemas técnicos disponibilizam e fomentam sua utilização; também os dados da psicosfera atual o fazem. Os conteúdos imateriais do território são igualmente essenciais para a banalização do uso dos cartões de crédito. Como exemplos destes conteúdos imateriais, podemos lembrar as campanhas publicitárias, as estratégias de venda das firmas administradoras de cartão, das redes de varejo etc.

Dados da Associação Brasileira das Empresas de Cartões de Crédito e Serviços (ABECS) nos dão um retrato mais aproximado dessa evolução do uso de cartões de crédito no Brasil, nestes últimos 15 anos:

Tabela 38: Brasil: Evolução do Número de Cartões de Crédito e de Transações Realizadas (1991-2005)

\begin{tabular}{|lr|r|r|r|r|r|r|r|}
\hline & & 1991 & 1994 & 1997 & 2000 & 2003 & 2004 & 2005 \\
\hline $\begin{array}{l}\text { No. de } \\
\text { (milhões) }\end{array}$ & cartões & 7,9 & 11,2 & 19,3 & 29 & 45 & 53 & 68 \\
\hline $\begin{array}{l}\text { No. de } \\
\text { (milhões) }\end{array}$ & transações & 105,7 & 210,3 & 516,7 & $1.000,3$ & 1.100 & 1.400 & 1.700 \\
\hline
\end{tabular}

Fonte: Elaboração própria a partir de dados da ABECS e Folha de São Paulo 2003.

Assim como vimos para os índices do fenômeno geral do crédito pessoal, o crescimento recente do uso deste objeto técnico também é bastante pronunciado, tanto em termos brutos, quanto relativos. Se tomarmos como base para a análise o período de 1994-2005, vemos que o número de cartões aumenta em cerca de 507\%. Com relação ao número de transações permitidas por este objeto técnico para o mesmo período, a proporção não é menos expressiva: há um aumento de cerca de $709 \%$ nas operações realizadas. 
No ano de 2000, foram movimentados (apenas com cartões de crédito) cerca de $R \$ 48,4$ bilhões; este valor perfaz a seguinte evolução nos demais anos: $R \$ 63,6$ bilhões em 2001 (crescimento de $31 \%$ em relação a 2000); $R \$ 73,0$ bilhões em 2002 (crescimento de 15\%); R \$ 88,0 bilhões em 2003 (20\%); R \$ 101,3 bilhões em 2004 ( $15 \%$ de aumento); e finalmente R\$ 123 bilhões em 2005 (representando um crescimento de $21 \%$ em relação a 2004).

Não pareceu fortuito, ainda, o fato de que na nova fase instalada pelo Plano Real (com o recuo significativo dos índices de inflação na economia brasileira), o uso de cartões de crédito teve um crescimento vultoso. Como mostra estudo do Banco Central supracitado (BANCO CENTRAL DO BRASIL, 2004:8):

1) o número de cartões de crédito evoluiu de 29,4 milhões (média de um cartão para cada 5,7 habitantes), em 2000, para 53,5 milhões em 2004 (média de um cartão para cada 3,4 habitantes), com variação da ordem de $82,0 \%$ no período (média de $16,2 \%$ a.a);

2) em 2004 foram efetuadas cerca de 1,3 bilhão de transações com cartões de crédito, no valor global de $\mathrm{R} \$ 92,5$ bilhões, com valor médio de cerca de $\mathrm{RS}$ 74,00 por transação. No período $2000 / 2004$, as transações com cartões de crédito cresceram 77,4\% em quantidade (média de 17,4\% a.a).

A chamada "indústria de meios de pagamentos" (isto é, as empresas de criação/manipulação de cartões de crédito e débito) é uma das que mais cresce atualmente, em relação com as demais empresas ligadas à prestação de serviços financeiros. Para Max Basile (2000:73), "utilizando sua enorme capacidade de rede instalada, sua expertise como facilitadora de transações e liquidações financeiras, a indústria de meios de pagamento pode estar acenando para o início de uma nova onda de conquistas".

Parece importante destacarmos que não só pelo fato de se constituir num elemento típico do sistema técnico e financeiro contemporâneo é que os cartões de crédito conheceram essa difusão tão expressiva. O comportamento das próprias empresas 
- interessadas em aumentar vendas, número de clientes, participação em mercados - contribuiu sobremaneira para tornar esse processo ainda mais expressivo. $\mathrm{Na}$ verdade, a somatória das tecnologias ligadas à circulação das finanças permite a criação de formas organizacionais, renovadas, para as empresas comerciais, que adequam suas estruturas para acompanhar este movimento de creditização do território. 
O território brasileiro na década de 1990 é bastante urbanizado, integrado do ponto de vista de sua infra-estrutura física, e possui um denso meio técnicocientífico-informacional (ainda que desigualmente distribuído) fazendo parte de sua constituição. A grande novidade deste período - que gradativamente foi se somando a todos os conteúdos do território - são as técnicas informacionais.

As redes-suporte de telefonia celular, os serviços telemáticos proporcionados pelos satélites artificiais, assim como as redes de fibra ótica são exemplos dessa empiricização das técnicas informacionais. As técnicas informacionais são o instrumento privilegiado da "unicidade técnica" (SANTOS, 1996) do mundo atual. Mas a banalização profunda de sua utilização se dá pelos novos usos do território que ela permite. Com este tipo de técnica, é permitida uma velocidade muito maior dos fluxos imateriais, assim como a instantaneidade de alguns deles. Passa a ser mais comum também a chamada "tele-ação", isto é, a utilização das técnicas da informação para a realização de um comando remoto do território, que não depende mais da presença (ou proximidade) dos atores decisores em relação aos contextos sobre os quais têm comando. Um comando muito mais centralizado das regiões, dos processos produtivos e da organização das sociedades é, portanto, permitido.

Esta tele-ação é um dos primeiros elementos que permitiram um expressivo processo de internacionalização ou desnacionalização dos sistemas de engenharia de todos os tipos: da telefonia, da geração energética, dos transportes etc. O mundo se tornou global em função da utilização destas técnicas da informação, e do controle remoto dos processos econômicos que elas autorizam. As empresas globais, que já eram bastante internacionalizadas desde ao menos meados do século $\mathrm{XX}$, se tornaram praticamente onipresentes a ao menos nas "áreas luminosas" do espaço geográfico de cada País). 
Essa tecnosfera instalada, por seu turno, vem acompanhada de um novo sistema de crenças, discursos, formas de entendimento do mundo, que podemos denominar de psicosfera (SANTOS, 1994; 1996; SILVEIRA, 1999). Duas das mais importantes componentes desta psicosfera instalada no país nos anos 1990 foram a ideologia da privatização e a ideologia do consumo. Ambas, a bem da verdade, sempre estiveram presentes no território; mas foi com a banalização das técnicas informacionais e o aumento da influência das corporaçôes globais no cenário mundial, que elas ganharam foro de "verdade constituída".

A psicosfera instituída identificou duas variáveis macroeconômicas como sendo os principais problemas da nação (a inflação e o endividamento público), e passou a trabalhar para sanear estes dois "problemas", indicando um caráter meramente "financista" das políticas econômicas do Governo Federal (CNBB, 2000:46). Esta rigidez da psicosfera instalada se manteve, e trouxe uma desorganização de todas as demais variáveis que compõem os conteúdos do território brasileiro (as redes de prestação de serviços públicos, as empresas estatais, os tempos locais e/ou regionais etc.). E erigiu também outra ideologia como ponto central dos conteúdos imateriais do território: a ideologia do consumo.

Estes discursos ideológicos nos quais se estabeleceu a psicosfera no país foram o lubrificante necessário para que todo o processo de privatização das empresas estatais se consumasse sem grandes dificuldades na década de 1990. Com uma população considerada como consumidores potenciais - e não como cidadãos de fato - os próprios governos instalados no Executivo Federal executaram as ações necessárias para que a enorme despatrimonialização de nossos sistemas de engenharia públicos se consumasse. Um dos ramos de atividades em que essa despatrimonialização foi mais expressiva é certamente o das finanças.

A reorganização do sistema bancário brasileiro no período em tela não teria sido instalada se não tivesse ocorrido uma enorme desregulação dos conteúdos normativos que asseguravam um controle mais orgânico por parte do Estado das 
atividades financeiras aqui desenvolvidas. Uma sucessão de alterações na legislação incidente no território vai, paulatinamente, permitindo que os vetores externos globais se fixem, assim como possibilitam que as instituições financeiras nacionais hegemônicas ampliem seu poder de organização do território.

Há um claro rearranjo no uso financeiro do território em favor das instituições financeiras estrangeiras, como tivemos a oportunidade de analisar no Capítulo 10. Esse conjunto de sistemas técnicos, ideologias e novas regulações jurídicas serviu, em grande medida, para tornar mais confortável a ação das empresas globais no território. A desregulação, neste sentido, não suprime as normas; ela as multiplica, mas a favor daqueles atores que têm o poder de transformá-las em seu proveito (SANTOS, 1996). Na esteira deste raciocínio, é possível também afirmar que a liberalização normativa se mostra bastante funcional para as grandes empresas (mormente as globais); para as empresas locais, estatais, ou não-hegemônicas, a liberalização é muito mais uma prisão, ou uma espécie de "decreto de pena de morte".

A bem da verdade, se há dois conjuntos de atores financeiros que viram seu poder e influência crescer no território, estes foram os bancos estrangeiros e os grandes bancos privados nacionais. Os "perdedores" deste novo arranjo foram os bancos públicos e os bancos pequenos e médios. A aniquilação do sistema de bancos públicos estaduais tornaria ainda mais verticalizado o arranjo federativo brasileiro, já que os estados da federação perdem o poder de coordenar suas finanças, e têm suas possibilidades de financiamento cada vez mais atreladas ao Governo Central, à liberação de recursos a partir da esfera da União.

O aumento do poder dos grandes bancos privados nacionais, assim como dos estrangeiros aqui instalados, permite que sejam criadas (e/ou aprimoradas) novas "redes corporativas" (DIAS, 1995; 2005) no território. A rede de mensageria internacional SWIFT parece ser um exemplo bem acabado deste tipo de sistema técnico, que nos anos 1990 teve um crescimento bastante pronunciado no mundo 
como um todo. No que diz respeito à formação socioespacial brasileira, a implementação do novo Sistema de Pagamentos Brasileiro (SPB) pode ser também considerada como um aprimoramento das "redes corporativas" do território; neste caso, O SPB vem aumentar a racionalidade e a eficiência da chamada Rede do Sistema Financeiro Nacional.

As redes corporativas aumentam exponencialmente a eficácia da ação das empresas financeiras hegemônicas. Por três principais motivos: a) elas aumentam a velocidade dos fluxos financeiros informacionais, e os tornam instantâneos em boa parte dos casos; b) elas imprimem também uma maior segurança aos fluxos hegemônicos, colaborando para que mais atores possam se utilizar destas redes; e c) elas diminuem sensivelmente os custos relacionados à movimentação de recursos, mensagens e informação. Assim, aumentam a produtividade sistêmica dos atores financeiros, e contribuem para que eles se tornem mais poderosos do que os demais atores econômicos presentes no território.

Outra das principais conseqüências deste novo padrão informacional e corporativo de uso financeiro do território tem relação direta com a topologia das instituiçôes $e$ das operações financeiras. Quais as principais alterações recentes ocorridas na topologia financeira brasileira?

Pensando na escala da formação socioespacial brasileira, faz-se necessário destacar que houve perda sensível da densidade financeira de algumas áreas "periféricas" do território. Esta perda de densidade financeira se deu, em primeiro lugar, em função do grande rearranjo patrimonial dos bancos ocorrido no âmbito do PROES e do PROER: praticamente todos os Estados da federação perderam o comando sobre instituições financeiras que Ihe pertenciam. Foi o caso dos Estados de Minas Gerais, Bahia e Paraná, que tiveram vendidas suas instituições financeiras privadas, e foi o caso também de todas as unidades da federação que tiveram seus bancos estaduais vendidos e/ou federalizados. 
Mas a perda de densidade financeira se deu também no nível local do território. O processo de fechamento de agências no Brasil inteiro significou, nesta escala, a diminuição da qualidade da prestação dos serviços bancários. A diminuição destes fixos geográficos fez também com que as cidades que dispunham de agências em seu meio urbano perdessem uma quantidade significativa de renda, dada pelo próprio capital necessário à manutenção do funcionalismo de cada agência.

A grande novidade da topologia bancária do período foi, sem sombra de dúvida, a difusão dos correspondentes bancários no território. Este fixo geográfico se mostrou ao mesmo tempo: a) bastante flexíve/ do ponto de vista da localização; b) econômico, no que tange aos custos fixos e variáveis envolvidos em sua manutenção; e finalmente c) funcional, no que diz respeito à possibilidade de promoção de políticas públicas e/ou privadas através deles. Sua expressiva e veloz expansão no território mostra que os correspondentes bancários podem ser considerados como elementos do espaço articuladores da "aceleração contemporânea" (SANTOS, 1996), uma aceleração bastante atrelada às vicissitudes das finanças.

Por fim, mas não menos importante, vimos que a partir desta nova topologia completada com o surgimento de uma série de "canais eletrônicos" financeiros foi concomitantemente sendo incrementada a concessão de créditos de todos os tipos no País, principalmente os créditos realizados às pessoas físicas.

Estas são as novas racionalidades instaladas no território, que aumentam sobremaneira tanto o alcance territorial da ação das instituições financeiras, assim como o poder delas para comandar os demais conteúdos e ações presentes no território brasileiro. Os tempos locais e regionais são cada vez mais substituídos pelos tempos nacionais ou globais, já que mesmo as famílias e os indivíduos passam a receber créditos, que alteram o ritmo de reprodução de suas vidas. As ações, portanto, perdem cada vez mais seu caráter orgânico com os lugares nos quais efetivamente se dão. Dada essa recente hipercapilaridade do acesso ao 
crédito, vê-se que se instala de forma ubíqua uma racionalidade vertical, financeira, que impõe muito mais uma solidariedade organizacional que uma solidariedade orgânica ao sistema de ações do espaço brasileiro. A finança se entroniza como principal variável do atual período histórico, e passa a comandar as regiões segundo suas vicissitudes. 
CONCLUSÃO 
A definição dos principais eventos pertinentes à evolução geográfica do sistema bancário brasileiro, assim como o recurso à periodização permitiu que definíssemos certas variáveis-chave de cada sistema temporal, que acabou por iluminar dialéticas centrais do espaço geográfico: a sucessão de seus elementos "novos" e a permanência dos "velhos", os processos sob comando do "Estado" ou do "mercado", a predominância de vetores "internos" ou "externos" na organização das regiões (SANTOS, 1985, 1988). A hierarquização destas dialéticas indicou uma totalidade para cada fase da periodização. Na década de 1940, André Cholley (1942, 1951) já propunha procedimento analítico semelhante, ao conceber seu método "genético e estrutural".

Desta abordagem geográfica do fenômeno das finanças que procuramos construir ao longo das três partes da tese, parece ser possível propormos três conjuntos de considerações finais para o trabalho. Um conjunto ligado ao conhecimento geográfico, um com significado mais político, e por fim um de ordem ética.

A principal conclusão relacionada ao conhecimento, ou à epistemologia da geografia, diz respeito ao papel ativo do espaço geográfico (SANTOS et alli, 2000). O estudo permitiu que fosse ressaltado, em primeiro lugar, um papel ativo dos conteúdos normativos do espaço geográfico, dos quais se procurou dar destaque à importância das normas jurídicas. Vimos que a ação normativa da SUMOC, por exemplo, coordenou a expansão da rede de agências bancárias no país, e ao mesmo tempo catalisou a concentração dos atores bancários. Assim ocorrera também com as normas consubstanciadas na Reforma Bancária de 1964/65. Através delas foi ainda tornado possível que novos atores financeiros se instalassem no território brasileiro, diversificando a divisão social do trabalho, e ampliando a quantidade e a qualidade das operações bancárias no País. A instituição da correção monetária - outra norma essencial do período - permitiu 
um incremento substancioso da drenagem de recursos financeiros por parte da rede de agências bancárias instalada no território.

Recentemente, as Resoluçôes do Banco Central acerca dos correspondentes bancários (também uma manifestação concreta dos conteúdos normativos do território) parecem ser outro exemplo bem acabado desse caráter ativo. Autorizado pela nova legislação em vigor, o sistema bancário nacional em poucos anos criou a mais capilarizada rede de prestação de serviços financeiros da história do País, através da difusão dos correspondentes bancários no território.

Se há uma influência manifesta dos conteúdos normativos do território, há sem sombra de dúvida uma ação também dos conteúdos técnicos do espaço. A combinação nacional e regional de técnicas (agrícolas, industriais, de transportes, de comunicação etc.) talvez seja, em verdade, a mais expressiva manifestação deste papel ativo do espaço geográfico.

A tecnificação do espaço nacional, isto é, a expansão de um meio técnico-científico sobre um meio natural ou pré-técnico, foi um fator bastante atuante no surgimento do moderno sistema bancário brasileiro. Tanto pela construção dos grandes sistemas de engenharia no território (estradas, portos, usinas, indústrias, infraestruturas urbanas) assim como pela cientifização da agricultura (isto é, a dotação do espaço agrícola de insumos técnicos de todo tipo), foi gerada uma série de novas demandas de "capital adiantado", em prazos curtos, médios e longos, que levaram à instalação no território de uma rede cada vez mais difusa de fixos geográficos para a prestação de serviços bancários. Esta, na verdade, é a própria dinâmica da "creditização do território" (SANTOS, 1993; 1994): a demanda por recursos financeiros das regiões tecnificadas instala concomitantemente os sistemas de objetos e de ações voltados para o suprimento destas demandas.

A própria topologia bancária, neste sentido, também apresenta um caráter ativo no desenvolvimento da nação. No caso dos correspondentes bancários, como vimos, 
trata-se de uma rede hipercapilarizada, que rapidamente foi instalada no território, e que passa a agir no sentido de oferecer novas possibilidades de uso financeiro do espaço nacional, para todos os tipos de atores que se utilizam da rede.

Os objetos e suas redes, portanto, autorizam (ou não) determinadas ações no espaço nacional. E já que os correspondentes fazem parte de um complexo sistema técnico, fruto da "unicidade técnica" global estabelecida no atual período histórico (SANTOS, 1994; 1996), eles podem tanto ser um veículo para ações de caráter local, como para aquelas de escala regional, nacional ou global. Mas a nova topologia bancária aumentou sensivelmente as possibilidades de ação dos atores hegemônicos que organizam o espaço financeiro nacional: tanto os grandes bancos públicos, quanto os privados. No caso dos bancos privados, a nova topologia catalisa principalmente a drenagem capilarizada da poupança da população que se bancariza, além de permitir uma extensiva venda de produtos financeiros de toda sorte (crédito consignado, seguros, serviços bancários etc.), por parte das instituições financeiras.

No caso dos bancos públicos, como tivemos a oportunidade de mostrar, esta rede possibilitou ainda a execução de políticas sociais de âmbito nacional, hipercapilarizadas, como foi o caso da utilização dos correspondentes da Caixa Econômica Federal para a consecução do Programa "Bolsa Família". Dada a hipercapilaridade da rede, e o maior contingente populacional bancarizado a partir dela, estas políticas sociais conseguiram uma maior eficiência, repercutindo justamente naquelas áreas do território tradicionalmente menos alcançáveis pelas políticas públicas. Somente neste período atual é que situações como essas são possíveis; situações em que "vários pontos distantes são, ao mesmo tempo, atingidos a partir de um mesmo centro decisório que envia suas mensagens e ordens com eficácia", lembra-nos Milton Santos (1996:179).

As técnicas da informação são as grandes responsáveis por esta nova qualidade do espaço geográfico. No caso de sua relação com o sistema bancário, as técnicas da 
informação é que tornaram viável, num primeiro momento, um aumento expressivo da produtividade do trabalho bancário. Seja através das redes de mensageria internacionais, dos canais eletrônicos ou da automação bancária, a introdução das técnicas informacionais nos bancos dispensou mão-de-obra, diminuiu custos, hipercapilarizou a rede bancária e tornou possível uma mobilidade e ubiqüidade sem precedentes para a finança.

Mas a introdução das técnicas da informação permitiu também uma maior centralização do comando das instituições financeiras, que aumentou ainda mais a concentração dos depósitos, créditos, sedes de bancos, agências, em parcelas privilegiadas do território brasileiro. $\mathrm{O}$ avanço das tecnologias de transmissão de dados por satélites, fibras óticas, ondas de radiofreqüência, tornou igualmente mais seguras e eficientes as transações bancárias de todos os tipos, permitindo um aumento do número de produtos financeiros à disposição da população do país. Multiplicaram-se os chamados "canais eletrônicos" em função desta nova base técnica, e a riqueza do território é drenada para o sistema financeiro ainda com mais vigor. Essa acumulação capitalista centrada no sistema financeiro, por sua vez, inibe a transformação material dos sistemas de engenharia do território, como a que ocorrera nas décadas de 1960 e 1970.

Esse conjunto novo de possibilidades que se abre, a cada período histórico, em função das características dos conteúdos do território é o que se pode entender como o papel ativo do espaço geográfico. A variação temporal e regional de sistemas de engenharia, de legislações, de densidades demográficas, de formas de comunicação autoriza (ou não) que os eventos do País e do mundo se instalem nos lugares. Procurou-se, neste sentido, "pensar o território como ator e não apenas como palco, isto é, o território no seu papel ativo"[SANTOS e SILVEIRA, 2001:11).

Não se trata, portanto, de um novo determinismo. Parece-nos apenas ser o caso de considerar o espaço "não apenas como resultado", mas também como "parte 
da explicação", como propôs há tempos Doreen Massey (1984:4). A concepção de um espaço geográfico que tem como parte constitutiva íntima tanto a materialidade do mundo (os objetos) quanto a vida que o anima (os atores suas ações), possibilita captar o movimento ininterrupto do processo de totalização histórica, sob o viés geográfico. Conforme frisado, as ações dependem da materialidade para serem realizadas, e seu destino final é sempre o acionamento de algum objeto; assim como a materialidade dos objetos, por maior que seja sua intencionalidade em termos técnicos, jamais vai tomar parte do processo de totalização histórica sem ser funcionalizada pelas ações. Esta é a principal dialética do espaço geográfico, da qual procuramos nos valer para entender a relação do território brasileiro com as finanças.

Conforme frisado, a progressão da análise permitiu que estabelecêssemos um segundo conjunto de conclusões. Este conjunto, também fundado no sistema de conceitos utilizado no estudo, pareceu-nos ter um significado político pois diz respeito à atual predominância de verticalidades em lugar de horizontalidades, na organização do território. Isto é, o uso contemporâneo do espaço brasileiro revela uma "correlação de forças" (GRAMSCl, 1949, 1993) ou um "antagonismo" (DUVERGER, 1964, 1975) que se funda predominantemente em solidariedades organizacionais em lugar de solidariedades orgânicas.

Essa realidade demorou a se instalar. A história do uso financeiro do território brasileiro tem início, como mencionamos, com o predomínio quase completo da vida regional sobre as variáveis demográficas, industriais, e principalmente financeiras. Esse predomínio, no caso da relação do território com as finanças, era manifestado pelo tipo de ator que compunha o sistema bancário no país: os "bancos emissores regionais". Estas instituições tinham autonomia para imprimir suas moedas, e essas moedas só possuíam verdadeira liquidez dentro da área da instituição financeira que as emitira. Neste período, era a região, a contigüidade quem comandava a finança. 
Com a evolução das técnicas dos transportes e das comunicações, assim como em função das novas moedas e técnicas bancárias que foram sendo criadas ao longo dos sucessivos períodos históricos, a finança foi cada vez mais se autonomizando dos demais conteúdos do espaço. Se até meados do século passado é possível afirmar que a finança ainda é "nacional" em grande medida, e funciona em maior consonância com as vicissitudes da formação socioespacial brasileira, no final do mesmo século esta situação se altera. Com a formação das redes financeiras globais, somada à "titularização" da riqueza, o dinheiro efetivamente se globaliza. Esta realidade é que permite que Benjamin Cohen (1998) advogue a tese de que vivemos numa época de diminuição da "soberania territorial" sobre o dinheiro, e que este é cada vez mais "desnacionalizado".

As restrições normativas, remanescentes de um período de maior controle do Estado sobre a vida da nação, são paulatinamente alteradas em favor dos atores globais. Os territórios se curvam frente a estes atores. Assim, a finança se entroniza como o principal pilar da organização do espaço brasileiro, em detrimento de todos os demais conteúdos promotores de contigüidades no espaço: os conteúdos demográficos, industriais, culturais, sejam eles nacionais, regionais ou locais.

Essa verticalização do uso do território e de seu sistema bancário tem na psicosfera da nação um influente catalisador. Principalmente a partir da instalação do Plano Real, a finança (e suas correlatas "inflação", "endividamento" e "taxa de juros") foi definitivamente eleita como o pilar das políticas públicas do Governo Federal. Toda uma série de combinações locais de elementos do espaço geográfico é transformada verticalmente a partir de então, para a resolução da "questão financeira". Essa verticalização, por seu turno, tem relação direta com dois processos: a evolução do controle das instituições bancárias no País e a organização da topologia do sistema bancário. 
Ao menos até a década de 1980, o predomínio de atores nacionais e/ou estatais no sistema bancário brasileiro impediu que a finança se entronizasse no comando da organização do território. Como vimos para o caso do BNDE, sua ação sempre se preocupou com o desenvolvimento de vários conteúdos do espaço nacional (industriais, comerciais, dos transportes, de desenvolvimento urbano etc.), e não apenas com a reprodução da finança enquanto finança. Mesmo os empréstimos externos, verticais por definição, passavam antes pelo filtro da ação do Banco, e se instalavam no território de acordo com um planejamento nacional. Neste sentido, o BNDE trabalhava para que a finança se horizontalizasse no espaço nacional. O uso da finança pelo Banco diluía o impacto geográfico do dinheiro internacional, produzindo contigüidades no território, através do financiamento de uma série de circuitos produtivos, criando sistemas de engenharia, indústrias, empregos etc.

Esse pareceu ser também o sentido da ação dos bancos federais regionais, assim como de toda a rede de bancos estaduais. Dotados de uma relação histórica com sua região, manejados por burocracias também formadas em suas respectivas áreas de atuação, os bancos oficiais regionais e estaduais em certo sentido impediam a incisão vertical do fenômeno das finanças nas diferentes parcelas do território brasileiro. Ainda que a ação destas instituições concentrasse também a riqueza a favor de certos sistemas de ação locais - tema que daria certamente um outro estudo - sua influência na distribuição mais regionalizada dos recursos financeiros parece ser uma manifestação de um uso mais horizontal das finanças no País.

Esta situação geográfica mais horizontalizada recebeu duro golpe a partir de 1994, como vimos. O processo de privatização dos bancos públicos alterou expressivamente a dialética entre o público e o privado no território, com claro predomínio deste segundo conjunto de interesses na organização do sistema financeiro. Mas modificou também, como pudemos analisar, a dialética entre o local e o global, também com efetiva predominância das vicissitudes forâneas nos usos do território tornados possíveis. 
Além de termos acompanhado a hegemonização de lógicas de mercado (privadas) e globais (externas) no comando dos depósitos e créditos realizados no território, vimos ainda que a nova topologia bancária se tornou um elemento de comunicação vertical das finanças com o território brasileiro. Tornou-se mais vertical por dois principais motivos. Em primeiro lugar, porque ao privatizar e desnacionalizar parte expressiva do sistema bancário público existente, tirou das regiões de atuação dos bancos a possibilidade de comando sobre as finanças locais. As sedes dos bancos são desancoradas de seus lugares de origem, e passam a funcionar em parcelas do território já dotadas de uma densidade financeira bastante robusta. Este processo de diminuição dos centros de gestão inibe a horizontalização do uso dos recursos financeiros da nação.

No nível local, esse esvaziamento dos conteúdos decisórios das regiões mais periféricas do território é também patente. Ele se deu basicamente através da recente substituição de uma topologia bancária fundada em agências para uma topologia fundada em correspondentes bancários. As agências, fixos geográficos mais complexos, mais intensivos em trabalho e dotados de quadro de funcionários capazes de realizar também a horizontalização das finanças no nível local, são paulatinamente fechadas nas "áreas opacas" do território, e substituídas pelos correspondentes bancários. Estes, como vimos, servem muito mais como correias de transmissão das vicissitudes dos centros que os controlam, do que como possível mecanismo de desenvolvimento local/regional.

Sem possibilidades de decidir sobre a circulação das finanças, os "lugares letárgicos" (SILVEIRA, 1994) do território vêem impossibilitadas práticas de horizontalização das finanças nacionais. Com uma rede-suporte hipercapilarizada, é permitida à inteligência do capital controlar os usos financeiros do espaço. A partir de 1994, o horror vacui financeiro de Bukharin finalmente se consuma no território brasileiro. 
Por último, vale destacar um conjunto de preocupações de ordem ética. A consecução das verticalidades no território pode ser considerada, no limite, como "a morte da política" (SANTOS, 2000). Racionalidades e vicissitudes de empresas financeiras do centro do sistema capitalista se impõem a tudo e a todos, de forma a desorganizar os arranjos de objetos e de ações horizontalmente existentes no país. A questão parece mais preocupante pois, a bem da verdade, nunca houve uma integração efetiva do País; passamos, ao longo de cinco séculos de história, de um "espaço sem nação" a um "espaço transnacionalizado"(SANTOS, 1979c). Que fazer?

Há tempos, o geógrafo Josué de Castro em seu clássico Geopolítica da Fome $[1951,1968: 53)$ preconizava a necessidade de "pôr-se o dinheiro a serviço do homem e não de fazer-se o homem escravo do dinheiro". Aprofundados os problemas em relação ao controle da finança, mas aprimoradas também as possibilidades de organização social pelas técnicas da informação, talvez seja possível falarmos na implementação de uma política verdadeiramente territorial ou geográfica para o controle das finanças, a favor dos homens.

É preciso reverter o sentido, ou o uso da topologia bancária hipercapilarizada; ao invés de utilizá-la como instrumento de drenagem dos recursos locais ou regionais, faz-se mister torná-la um elemento de irrigação do território com recursos. E pulverizar as possibilidades de seu controle. Esta necessidade de um controle local maior sobre as variáveis-chave do processo de desenvolvimento é que levou, há tempos, François Perroux (1967:144) insistir na proposição radical de que a condução das políticas de desenvolvimento nos países pobres deve ser "dirigida por autóctones, e largamente orientada por demandas autóctones". Menos enfático, mas também imbuído desta preocupação com a totalidade dos atores e das regiões, André-Louis Sanguin (1977:115) mostrava que "quadros superiores, gerentes ou tecnocratas, raciocinam em função de sua empresa, e não em função da opinião local", da "vida cívica e do comércio" de cada cidade. 
Destarte, ao contrário do que se apregoa pela psicosfera hegemônica atual, é preciso desalienar os usos locais do espaço geográfico, e diminuir as velocidades de circulação do capital. A dinamização dos vetores especulativos, por definição autistas, vai em sentido contrário à necessidade da criação de horizontalidades. Transformar os capitais fluidos em permanentes, tirá-los da esfera da circulação para o mundo dos capitais fixos, contíguos, não-financeiros, pode ser uma forma eficiente de tornar o uso do território menos corporativo, e mais cidadão. É preciso voltar à valorização das populações em "suas realidades concretas locais (históricas e humanas)", como há tempos também preconizou o líder guineense Amílcar Cabral (1980:29). Na metáfora genial do geógrafo Milton Santos (2002), faz-se hoje mais do que nunca necessário valorizar o chão contra o cifrão. 


\section{BIBLIOGRAFIA}


ACCORSI, André. Automação: Bancos e Bancários. FEA/USP (Dissertação de Mestrado). 1990.

ADENOT, ]. e ]-M. Albertini. La Monnaie et les Banques. Initiation. Paris. Éditions du Seuil. 1975.

ALBERTIN, Alberto Luiz. "Comércio eletrônico: um estudo do setor bancário". In Revista de Administração Contemporânea Vol. 3 No. 1. 1999. pp. 4770.

ALLIX, André. "La Banque et la géographie, d'après un exemple régional". In Revue de Géographie de Lyon Vol. XXXI, No. 1. 1956. pp. 33-38.

ALMEIDA, Eliza. A Metropolização-Periferização Brasileira no Período TécnicoCientífico-Informacional. São Paulo. Departamento de Geografia FFLCH/USP (dissertação de mestrado). 2001.

ALTHUSSER, Louis (1974). Aparelhos Ideológicos de Estado. São Paulo. Editora Graal (8a. ed.). 2001.

ANATEL. Relatório Anual. 2000. 60 p.

ANATEL. Sítio da Instituição. 2006.

ANDERSON, James. "A Nova Direita e a privatização: malogro britânico, lições mundiais". IN Espaço e Debates No. 12. 1991. pp.

ANDIMA. Sistema de Pagamentos Brasileiro. Relatório Econômico. Rio de Janeiro. ANDIMA. 2002. 156 p.

ANTAS Jr., Ricardo Mendes. Território e Regulação. Espaço Geográfico, Fonte Material e Não-Formal do Direito. São Paulo. Associação Editorial Humanitas/FAPESP. 2005.

ARAújO FILHO, José Ribeiro. "O Café, riqueza paulista". In Boletim Paulista de Geografia No. 23. 1956. pp. 78-135.

ARMIJO, Leslie e Prem Shankar Jha. "Center-state relations in India and Brazil: privatization of electricity and banking". In Revista de Economia Política Vol. 17, No. 3. 1997. pp. 120-142. 
ARROYO, Mónica. "A Espacialidade do futuro. Além das fronteiras nacionais?". In Ensaios FEE Ano. 16, No. 2. 1995. pp. 491-509.

. "Território brasileiro e mercado externo: uma leitura dessa relação na virada do século XX". In SOUZA, Maria Adélia (ed.). Território: Usos e Abusos. Campinas. Edições Territorial. 2003. pp. 429-457.

- "Fluidez e porosidade do território brasileiro no contexto da integração continental". In SILVEIRA, María Laura (org.). Continente em Chamas. Globalização e Território na América Latina. Rio de Janeiro. Civilização Brasileira. 2005. pp. 209-242.

AZEVEDO, Fernando. Um Trem Corre Para o Oeste. São Paulo. Editora Martins. 1950.

AZEVEDO, Thales e E. Q. Vieira Lins. História do Banco da Bahia (1958-1958). Rio de Janeiro. Livraria José Olympio Editora. 1969.

BAER, Mônica. A Internacionalização Financeira no Brasil. Petrópolis. Editora Vozes. 1986.

BAER, Werner e Nader Nazmi. "Privatization and restructuring of banks in Brazil". In The Quarterly Review of Economics and Finance no. 40. 2000. pp. 324.

BAILLY, Antoine. "La Chronogéographie". In BAILLY, Antoine (et alli). Les Concepts de la Géographie Humaine. Paris. Masson. 1995. pp. 173-176.

BAKIS, Henry. Géopolitique de L'Information. Paris. PUF. 1987.

BANCO CENTRAL DO BRASIL. Atendimento Bancário Realizado por meio de Correspondentes Bancários. 2006 lextraído de http://www.bcb.gov.br/htms/Deorf/r200212/quadro11 .asp?idpai=REVSF N200212).

BANCO CENTRAL DO BRASIL. Estatística Bancária. 2006. Disponível em http://www.bcb.gov.br/htms/Deorf/r200412/quadro20.asp?idpai=REVSF N200412 (acesso em 15/09/2005)

BANCO CENTRAL DO BRASIL. O Sistema Brasileiro de Pagamentos. Brasília. DEBAN - Departamento de Operações Bancárias e de Sistema de Pagamentos. 2004. 
BANCO CENTRAL DO BRASIL. O Sistema de Pagamentos Brasileiro. Departamento de Operações Bancárias e Sistemas de Pagamento. Brasília. 2004. 45 p.

BANCO CENTRAL DO BRASIL. PROES. Supervisão e Saneamento. 2006. disponível em http://www.bcb.gov.br/lid/gedes/proesTitulosEmitidosReal.ASP?id=proes)

BANCO CENTRAL DO BRASIL. Relatório de Atividades da Diretoria de Fiscalização (1995-2002). 2006 (extraído de http://www.bcb.gov.br/ftp/defis/RelAtiv8/capitulo_5.pdf em 29/10/2006).

BANCO CENTRAL DO BRASIL. Sistema de Pagamentos Brasileiro. 2006. disponível em http://www.bcb.gov.br/?SPB Acesso em 19/10/2006.

BANCO CENTRAL DO BRASIL. Sistema de Pagamentos Brasileiro. Introdução. 2006. disponível em http://www.bcb.gov.br/?SPBINTROD

BANCO CENTRAL DO BRASIL. "Sistema Financeiro Nacional. 1989-2000". retirado do sítio http://www.bcb.gov.br/htms/Deorf/e882000/texto.asp?idpai=relsfn 19882000 em 13/09/2006.

BARAN, Paul. "El compromiso del intelectual". In Excedente Económico e Irracionalidad capitalista. Córdoba. Cuadernos de Pasado y Presente No. 3. 1968. pp. 9-20.

BARAT, Josef. A Evolução dos Transportes no Brasil. Rio de Janeiro. IBGE/IPEA. 1978.

BARROS DE CASTRO, Antonio. Sete Ensaios Sobre a Economia Brasileira. Rio de Janeiro. Editora Forense Universitária. 1971.

BARROS DE CASTRO, Antonio e Francisco Pires de Souza (1985). A Economia Brasileira em Marcha Forçada. Rio de Janeiro. Paz e Terra. 2004.

BASILE, Max. E o Dinheiro Virou Plástico. Os Desafios de um Novo Universo de Negócios. São Paulo. Cultura Editores Associados. 2000.

BAUDRILLARD, Jean (1968). O Sistema de Objetos. São Paulo. Editora Perspectiva. 1993.

BEAUD, Michel. Le Système National/Mondial Hierarquisé. Une Nouvelle du Capitalisme Mondiale. Paris. La Découverte. 1987. 
BECKER, Berta e Cláudio Egler. Brasil: Uma Nova Potência Regional na EconomiaMundo. Rio de Janeiro. Editora Bertrand Brasil. 1993.

BelGuElMAN, Paula. Formação do Povo no Complexo Cafeeiro. Aspectos Políticos. São Paulo. Editora Pioneira. 1968.

- Pequenos Estudos de Ciência Política. São Paulo. Livraria Pioneira Editora (2a . ed.). 1973.

BELLUZZO, Luiz Gonzaga de Mello. O Senhor e o Unicórnio. A Economia dos Anos 80. São Paulo. Brasiliense. 1984.

BENKO, Georges e Alain Lipietz (orgs.). As Regióes Ganhadoras. Distritos e Redes: os Novos Paradigmas da Geografia Econômica. Oeiras. Celta Editora. 1994.

BENNETT, Richard. Geography of Public Finance. Welfare Under Fiscal Federalism and Local Government Finance. London/New York. Methuen. 1980.

BERMANN, Célio. Energia no Brasil: Para Quê? Para Quem? São Paulo. Livraria da Física Editora. 2003.

BERNARDES, Adriana. A Contemporaneidade de São Paulo. Produção de informações e Novo Uso do Território Brasileiro. São Paulo. Departamento de Geografia FFCLH/USP (Tese de Doutorado). 2001.

BERNARDES, Julia Adão. "As estratégias do capital no capital no complexo da soja". In CASTRO, Ina Elias de., Paulo César C. Gomes e Roberto Lobato Corrêa (orgs.). Brasil. Questóes Atuais da Reorganização do Território. Rio de Janeiro. Bertrand Brasil. 1996. pp. 325-366.

BERRY, Brian J. L. (1967). Geografía de los Centros de Mercado y Distribución al por Menor. Barcelona. Editorial Vicens-Vives. 1971.

BIBLIEX. A Energia Elétrica no Brasil. Da Primeira Lâmpada à Eletrobrás. Rio de Janeiro. Biblioteca do Exército Editora. 1977.

BICUDO Jr., Edison. O circuito Superior Marginal. Produção de Medicamentos e o Território Brasileiro. São Paulo. Departamento de Geografia FFLCH/USP (Dissertação de mestrado). 2006.

BIDERMAN, Maria Tereza C. Dicionário de Termos Financeiros e Bancários. São Paulo. Disal Editora. 2006. 
BNDES. Privatizaçôes Federais. PND. 2006. Disponível em http://www.bndes.gov.br/privatizacao/resultados/federais/federal.asp

BORIN, Paula. Divisão interurbana no trabalho e uso do território nos municípios de Águas de Lindóia (SP), Lindóia (SP), Serra Negra (SP), Socorro (SP) e Monte Sião (MG). São Paulo. Deptartamento de Geografia FFLCH/USP (Dissertação de Mestrado). 2002.

BOUZAN, Ary. Os Bancos Comerciais no Brasil. Uma Análise do Desenvolvimento Recente (1965-1971). São Paulo. Federação Brasileira das Associações de Bancos. 1972.

BRADESCO. O Bradesco e o Banco Postal. Evolução do Projeto e Resultados. Bradesco. 2006. disponível em http://www.bcb.gov.br/htms/Deorf/ISeminarioMicrofinancas/Palestras/10_2 P_Odair.ppt

BRAGA, Vanderlei. Bancos, NTI e Novo Uso do Território Brasileiro. O Caso do Banco Bradesco/Banco Postal. Campinas. IGEO/Unicamp (Monografia de Conclusão de Curso). 2003.

BRAUDEL, Fernand (1969). Escritos Sobre a História. São Paulo. Editora Perspectiva (2a. ed.). 1992.

- (1979). Civilização Material, Economia e Capitalismo Séculos XVXVIII Volume I. As Estruturas do Cotidiano. São Paulo. Martins Fontes. 2005.

BRUM, Argemiro Jacob. Modernização da Agricultura. Trigo e Soja. Petrópolis. Editora Vozes. 1988.

BRUNHES, Jean (1920). Geografia Humana. Rio de Janeiro. Editora Fundo de Cultura. 1962.

BRUNHOFF, Suzanne de. A Moeda em Marx. Rio de Janeiro. Paz e Terra. 1978.

BUKHARIN, Nicolai (1915). O Imperialismo e a Economia Mundial. Análise Econômica. Rio de Janeiro. Editora Laemmert. 1969.

BULHÕES, Octávio Gouveia de (et alli). A Evolução do Capitalismo no Brasil. Rio de Janeiro. Edições Bloch. 1976. 
BUNGE, Mario. Epistemologia. Curso de Atualização. São Paulo. T. A. Queiroz Editor. 1980.

CABRAL, Amílcar. A Arma da Teoria. Rio de Janeiro. Editora Codrecri. 1980.

CAIXA ECONÔMICA DO ESTADO DE SÃO PAULO. Centro de Memória. 1952.

CALDERÓN, Alvaro e Ramón Casilda. "La estrategia de los bancos españoles en America Latina". In Revista de la CEPAL No. 70. Abril de 2000. pp. 7189.

CANO, Wilson (1977). Raízes da Concentração Industrial em São Paulo. São Paulo. T. A. Queiroz Editora (3a. ed.). 1983.

CARONE, Edgar. A República Velha I. Instituições e Classes Sociais. São Paulo. Difel (3a. ed.). 1975.

CARVALHO, Carlos Eduardo. "Bancos e Inflação no Brasil: da Crise dos anos 1980 ao Plano Real". s/d. (disponível em http://www.abphe.org.br/congresso2003/Textos/Abphe_2003_56.pdf)

CARVALHO, Carlos Eduardo e Giuliano Contento de Oliveira. "Fragilização de grandes bancos no início do Plano Real”. In Nova Economia Vol. 12 (1). 2002. pp. 69/84.

CARVALHO, Carlos Eduardo, Rogério Studart e Antonio José Alves Jr. "Desnacionalização do Setor Bancário e Financiamento das Empresas: a Experiência Brasileira Recente". In IPEA/Textos para discussão No. 882. Maio de 2002. (75 p.).

CASTILLO, Ricardo. Sistemas Orbitais e Uso do Território. Integração Eletrônica e Conhecimento Digital do Território Brasileiro. São Paulo. Departamento de Geografia FFLCH/USP (Tese de Doutorado). 1999.

CASTILLO, Ricardo, Rubens Toledo Jr. e Júlia Andrade. "Três dimensões da solidariedade em geografia". In Experimenta/No. 3. 1997. pp. 69-99.

CASTRO, Helio O. Portocarrero de. "Mercado de Capitais no Brasil: A Evolução Recente". In CASTRO, Helio O. Portocarrero de (ed.). Introdução ao Mercado de Capitais. Rio de Janeiro. IBMEC. 1979. pp. 37-54. 
CASTRO, Josué de (1951). Geopolítica da Fome. Ensaio Sobre os Problemas da Alimentação e de População. (2 vols.). São Paulo Editora Brasiliense (8a. ed.). 1968.

CATAIA, Marcio. Território Nacional e Fronteiras Internas. A Fragmentação do Território Brasileiro. São Paulo. Departamento de Geografia FFCLH/USP (Tese de Doutorado). 2001.

CHESNAIS, François. "L'Émergence d'um regime d'accumulation à dominante financière". In La Pensée No. 309. 1997. pp. 61-85. . "Introdução geral". In CHESNAIS, François (coord.). A Mundialização Financeira. Gênese, Custos e Riscos. São Paulo. Xamã Editorial. 1998. pp. 11-33.

CHOlLEY, André (1942). La Géographie. Guide de I'Étudiant. Paris. Presses Universitaires de France. 1951.

COHEN, Benjamin. The Geography of Money. Ithaca/London. Cornell University Press. 1998.

CONFERÊNCIA NACIONAL DOS BISPOS DO BRASIL (CNBB). Pela Ética na Gestão do Sistema Financeiro Nacional. São Paulo. Edições Loyola. 2000. CONTEL, Fabio. "Os Sistemas de movimento do território brasileiro". In SANTOS, Milton e María Laura Silveira. Brasil. Território e Sociedade no Início do Século XXI. Rio de Janeiro. Record. 2001. pp. 357-374.

CORDEIRO, Helena Kohn e Francisco Bernardes. "O Espaço aéreo favorece a desterritorialidade?". In SANTOS, Milton (et alli). Território: Globalização e Fragmentação. São Paulo. Hucitec/Anpur. 1994. pp. 283295.

CORIAT, Benjamin. A Revolução dos Robôs. O Impacto Socioeconômico da Automação. São Paulo. Editora Busca Vida. 1989.

CORRÊA, Roberto Lobato (1989). "Concentração bancária e os centros de gestão do território". In CORRÊA, Roberto Lobato. Estudos Sobre a Rede Urbana. Rio de Janeiro. Bertrand Brasil. 2006. pp. 61-97. . "Os Centros de gestão e seu estudo". In Revista Brasileira de Geografia No. 51 (4). 1989. pp. 109-119. 
CORRÊA, Roberto Ribeiro. "BASA: Seis décadas de mudança institucional". In MENDES, Armando Dias (org.). A Amazônia e seu Banco. Manaus. Editora Valer/Banco da Amazônia. 2002. pp. 347-404.

CORREIOS. Banco Postal Muda Comportamento em Cidades sem Agências Bancárias. Brasília. Ministério das Telecomunicações. 2002. 5p. (disponível em http://www.correios.com.br/inaug_bancoPostal_press_release.pdf).

COSTA FILHO, Bento Alves da. Automação Bancária: Uma Análise sob a Ótica do Cliente. São Paulo. FEA/USP (Dissertação de Mestrado). 1996.

COSTA NETO, Yttrio da. Bancos Oficiais no Brasil: Origem e Aspectos de seu Desenvolvimento. Brasília. Banco Central do Brasil. 2004. 156p.

COSTA, Fernando Nogueira da. Banco do Estado: O Caso Banespa. Campinas. IE/Unicamp (Tese Doutorado). 2 vols. 1988. . “Acesso bancário". In Folha de São Paulo 08/11/2000a. . "Privação do Crédito". Folha de São Paulo 04/10/2000b.

COUTINHO, Eduardo S. e Hudson F. Amaral. "O Impacto do aumento da participação do capital estrangeiro no setor bancário brasileiro: análise de variáveis selecionadas". In Revista de Administração Pública Vol. 37(5). 2003. pp. 1013-1032.

COUTO E SILVA, Golbery do (1967). Conjuntura Política Nacional e Poder Executivo. Geopolítica do Brasil. Rio de Janeiro. Livraria José Olympio Editora. 1981.

CUSTÓDIO, Carlos Henrique. "Correspondente Bancário Caixa Aqui". Trabalho Apresentado no Seminário BACEN. Microfinancas. Fortaleza. 11 de novembro de 2003.2 disponível em http://www.bcb.gov.br/pre/SeMicro/Palestras/09_1_CarlosHenrique.ppt DARDEL, Eric. L'Homme et la Terre. Nature de la Realité Géographique. Paris. PUF. 1952.

DAYRIES, Jean-Jacques e Michelle Dayries. La Régionalisation. Paris. Presses Universitaires de France. 1978.

DE CARVALHO, Márcia Siqueira de. "Globalização e redes: o teletrabalho e o home-office banking”. In: DE CARVALHO, Márcia Siqueira (org.). 
Geografia, Meio Ambiente e Desenvolvimento. Londrina. UEL/A Autora 2003. pp.143-160.

DE CASTRO, Helio Oliveira P. As Causas da Concentração Bancária. Rio de Janeiro. IBMEC. 1981.

DE PAULA, Luiz Fernado R. "Tamanho, dimensão e concentração do sistema bancário no contexto de alta e baixa inflação no Brasil". In Revista Nova Economia Vol. 8. No. 1. 1998. pp.

DEAECTO, Marisa Midori. Comércio e Vida Urbana na Cidade de São Paulo (1889-1930). São Paulo. Editora SENAC. 2002.

DELGADO, Guilherme da Costa. Capital Financeiro e Agricultura no Brasil: 19651985. São Paulo/Campinas. Ícone Editora/Unicamp. 1985.

DEUTSCH, Karl W. Os Nervos do Governo. Análise de Modelos de Comunicação e do Controle Político. Rio de Janeiro. Bloch Editores. 1971.

DIAS, Leila. Réseaux d'Information et Réseau Urbain au Brésil. Paris. L'Harmattan. 1995.

- "Redes eletrônicas e novas dinâmicas do território brasileiro". In CASTRO, Iná Elias de (et alli). Brasil. Questóes Atuais de Reorganização do Território. Rio de Janeiro. Bertrand Brasil. 1996. pp. 115-144. . "Hegemonia financeira e geografia das redes bancárias". In SILVESTRE, Edu (org.). Que País é Esse? Pensando o Brasil Contemporâneo. São Paulo. Editora Globo. 2005. pp. 27-62.

DIEESE. Estudo Sobre a Avaliação do Banco do Estado de São Paulo (BANESPA). São Paulo. 2000. 59 p.

DINIZ, Eduardo. "Evolução do uso da WEB pelos bancos". In Revista de Administração Contemporânea Vol. 4, No. 2. 2000. pp. 29-50.

DOLFFUS, Olivier. "L'Espace financier et monétaire mondial". In L'Espace Géographique No. 2. 1993. pp. 97-102.

DOS ANJOS, Sergio Odilon. "Correspondentes no país". Palestra proferida no CIAB/FEBRABAN, em 23 de junho de 2006.

DOS SANTOS, Wanderley Guilherme (1979). Cidadania e Justiça. A Política Social na Ordem Brasileira. Rio de Janeiro. Editora Campus (2a . ed.). 1987. 
DOWBOR, Ladislau. A Reprodução Social. Propostas para uma Gestão Descentralizada. Petrópolis. Editora Vozes. 1998.

DUVERGER, Maurice (1964). Introdução à Política. Lisboa. Estudios Cor. 1975. ELIAS, Denise. Meio Técnico-Científico-Informacional e Urbanização na Região de Ribeirao Preto (SP). São Paulo. Departamento de Geografia FFLCH/USP (Tese de Doutoramento). 1996.

ELIAS, Luiz Antonio R. e Liane Maia Simoni. "Características institucionais e legais dos títulos financeiros". In CASTRO, Helio Porto C. de (ed.). Introdução ao Mercado de Capitais. Rio de Janeiro. IBMEC. 1979. pp. 91-121.

EVANS, Peter. A Tríplice Aliança. As Multinacionais, as Estatais e o Capital Nacional no Desenvolvimento do Capitalismo Dependente Brasileiro. Rio de Janeiro. Zahar Editores. 1980.

FAORO, Raymundo. Assembléia Constituinte. A Legitimidade Recuperada. São Paulo. Editora Brasiliense. 1981.

FASSY, Amaury. A Informática e o Futuro do Brasil. São Paulo. EMW Editores. 1985.

FEBRABAN. Portal de Informações. Módulo 1 - Crédito. s/d. 93 pp. disponível em http://www.febraban.org.br/Arquivo/Servicos/Dadosdosetor/modulodados-credito-internet.pdf

FERNANDES, Ana, Milton Santos Filho e Paulo Henrique de Almeida. "A Modernização do campo nos cerrados baianos". In Espaço e Debates Ano 8. No. 25. 1988. pp. 63-75.

FOCILLON, Henry (1943). A Vida das Formas (Seguido de Elogio da Mão). Lisboa. Edições 70. 1988.

FRANCO, Gustavo. "Idéias para a extinção dos bancos estaduais" In: Jornal do Brasil 17/10/1999; disponível em http://www.econ.pucrio.br/gfranco/cvport.htm

FRAY, Luigi. Desenvolvimento Econômico e Estrutura do Mercado Financeiro. Rio de Janeiro. Zahar Editores. 1961.

FREITAS, Maria Cristina P. de e Daniela Magalhães Prates. "Sistema financeiro e desenvolvimento: as restrições das novas regras do Comitê da Basiléia". In 
FERRAZ, João Carlos let alli). Liberalização Econômica $e$ Desenvolvimento. Modelos, Políticas e Restrições. São Paulo. Editora Futura. 2003. pp. 234-261.

FRIEDMAN, Georges. Sete Ensaios Sobre o Homem e a Técnica. São Paulo. Difel. 1966.

FRIEDMANN, John e Clyde Weaver. Territorio y Función. La Evolución de la Planificación Regional. Madrid. Institutos de Estudios de Administración Local. 1981.

FURTADO, Celso (1959). Formação Econômica do Brasil. São Paulo. Cia. Editora Nacional (25a ed.). 1995.

GARMAN, Christopher, Cristiane K. Leite e Moisés Marques. "O Impacto das relações Banco Central $\mathrm{X}$ bancos estaduais no arranjo federativo pósreal". In Anais do XXII Encontro Anual da ANPOCS. 1998.

GAZETA MERCANTIL. Rede Bancária Brasileira no Topo da Internet Global. 01/04/2003.

GEIGER, Pedro. Evolução da Rede Urbana Brasileira. Rio de Janeiro. Instituto Nacional de Estudos Pedagógicos/MEC. 1963.

GEIGER, Pedro Pinchas e Fany Davidovich. "Espaço e política no Brasil de hoje". In Revista de Administração Municipa/Vol. 30(168). 1983. pp. 18-25.

GEORGE, Pierre. A Ação do Homem. São Paulo. Difel. 1966. . Geografia do Consumo. São Paulo. Difel. 1971.

GERSCHENKRON, Alexander. "El atraso econômico em su perspectiva histórica". In VÁRIOS. Estudios Sobre el Nacimiento y Desarrollo del Capitalismo. Editorial Ayuso. 1978. pp. 147-160.

GIAMBIAGGI, Fabio e Ana Cláudia Além. Finanças Públicas. Teoria e Prática no Brasil. Rio de Janeiro. Editora Campus. 1999.

GIDDENS, Anthony (1991). As Conseqüências da Modernidade. São Paulo. Editora Unesp. 1994.

GOLDFINGER, Charles. La Géofinance. Pour Comprendre la Mutation Financière. Paris. Seuil. 1986. 
GOLDMANN, Lucien (1952). Ciências Humanas e Filosofia. O que é a Sociologia? São Paulo. Difel. 1979.

. A Criação Cultural na Sociedade Moderna. São Paulo. Difel. 1972.

GOLDSMITH, Raymond. Brasil: 1850-1980. Desenvolvimento Financeiro Sob um

Século de Inflação. São Paulo. Editora Harper \& Row do Brasil. 1986.

GOMES, Marcio Fernando. A Territorialidade dos Conglomerados Financeiros no Brasil. São Paulo. Deptartamento de Geografia FFLCH/USP (Tese de Doutorado). 2005.

GOTTMANN, Jean. "Vauban and the modern geography". In The Geographical Review Vol. 34. No.1. 1944. pp. 120-128.

- "De la méthode d'analyse en géographie humaine". In Annales de Géographie Tome LVI. 1947. pp. 1-12.

. "The Evolution of the concept of territory". In Informations Sur Les Sciences Sociales. No. 14, 3/4. 1975. pp. 73-93. . La Politique des États et leur Géographie. Paris. Armand Colin. 1952. . Review of Global Financial Integration: The End of Geography. In The Geographical Journal Vol. 159. 1993. pp.101.

GRAMSCl, Antonio (1949). La Política y el Estado Moderno. Buenos Aires. Editorial Planeta. 1993.

GRIMM, Flavia. O uso do território e coexistências entre empresas de refrigerantes no Brasil. São Paulo. Deptartamento de Geografia FFLCH/USP (Dissertação de Mestrado). 2002.

GUTIÉRREZ, Claudio Tito Gutiérrez. A Reestruturação dos Bancos Estaduais PósPROES. Análise do Caso Banrisul. Niterói. Universidade Federal Fluminense (UFF/Depto. de Economia). Dissertação de Mestrado. 2006. [disponível em http://www.uff.br/cpgeconomia/novosite/arquivos/ tese/2006claudio_tito.pdf?PHPSESSID $=55417231 \mathrm{fa} 2 \mathrm{~d} 8 \mathrm{e} 93 \mathrm{~d} 43098 \mathrm{~d} 217 \mathrm{af38d7}$ ) GUTTMANN, Robert. "As mutações do capital financeiro". In CHESNAIS, François (coord.). A Mundialização Financeira. Gênese, Custos e Riscos. São Paulo. Xamã Editorial. 1998. pp. 61-96. 
HÄGERSTRAND, Torsten. Innovation Diffusion as a Spatial Process. Chicago. Chicago University Press. 1953.

HAN, Sun Sheng e Clifton W. Pannel. "The Geography of privatization in China, 1978-1996". In Economic Geography Vol. 75. No. 3. 1999. pp. 272298.

HARVEY, David (1973). A Justiça Social e a Cidade. São Paulo. Hucitec. 1980.

HEIDEGGER, Martin (1954). Ensaios e Conferências. Petrópolis. Editora Vozes. 2002.

HILFERDING, Rudolf (1909). O Capital Financeiro. São Paulo. Nova Cultural. 1985.

HIRSCHMAN, Albert O. De Consumidor à Cidadão. Atividade Privada e Participação na Vida Pública. São Paulo. Editora Brasiliense. 1983.

IBGE. Sinopse Preliminar do Censo Demográfico 2000. 2006. Disponível em http://www.ibge.gov.br/home/estatistica/populacao/sinopse_preliminar/defa ult.shtm?c=10

INSTITUTO MCKINSEY. Produtividade no Brasil. A Chave do Desenvolvimento Acelerado. Rio de Janeiro. Editora Campus. 1999.

ISNARD, Hildebert. "Une Problématique empiriste de la géographie". In ISNARD, Hildebert, ]. B. Racine e H. Reymond. Problématiques de la Géographie. Paris. Presses Universitaires de France. 1981. pp. 15-83.

JABBOUR, Elias. China. Infra-Estruturas e Crescimento Econômico. São Paulo. Editora Anita Garibaldi. 2006.

JAGUARIBE, Hélio. O Nacionalismo na Atualidade Brasileira. Rio de Janeiro. Ministério da Educação e Cultura/ISEB. 1958.

JAMES, Preston. "Industrial development in São Paulo state, Brazil". In Economic Geography July, 1935. pp. 258-266.

JENKINS, Nise. Trabalho e Resistência na "Fonte Misteriosa". Os Bancários no Mundo da Eletrônica e do Dinheiro. Campinas. Editora da Unicamp/Imprensa Oficial do Estado. 2002.

KOSIK, Karel (1963). Dialética do Concreto. Rio de Janeiro. Paz e Terra. 1986. 
LABASSE, Jean e Michel Rochefort. "Equipements tertiaries supérieurs et réseau urbain“. In Économie et Humanisme No. 159. 1965. pp. 54-61.

LABASSE, Jean. Les Capitaux et la Région. Étude Géographique. Essai sur le Commerce et la Circulation des Capitaux dans la Région Lyonnaise. Paris. Librairie Armand Colin/Cahiers de la Fondation Nationale des Sciences Politiques. 1955.

LABASSE, Jean. L'Espace Financier. Analyse Géographique. Paris. Librairie Armand Colin. 1974.

LALANDE, André (1926). Vocabulário Técnico e Crítico da Filosofia. São Paulo. Martins Fontes Editora. 1996.

LEFEBVRE, Henri. "La Notion de totalité dans les sciences sociales". In Cahiers Internationaux de Sociologie, Vol. XVIII. 1955. pp. 55-77.

LEITE, Antonio Dias. A Energia do Brasil. Rio de Janeiro, Nova Fronteira. 1997.

LEME, Rui Aguiar da Silva. "Um modelo econométrico para fixação do número ótimo de agências bancárias por praça". In Anais do I Simpósio Brasileiro de Pesquisa Operacional e Suas Aplicações. Vol. II. São José dos Campos. Instituto Tecnológico da Aeronáutica. 1968. pp. 299-370.

. "Determinação do número ótimo de agências bancárias por praça”. In AZZONI, Carlos Roberto. Onde Produzir? Aplicaçóes da Teoria da Localização no Brasil. São Paulo. Instituto de Pesquisas Econômicas IPE/SP. 1985. 71-80.

LENIN, Vladimir (1907). El Desarrollo del Capitalismo em Rusia. El Proceso de Formación de un Gran Mercado Interior para la Gran Industria. Barcelona. Editorial Ariel. 1974.

.(1917). O Imperialismo, Fase Superior do Capitalismo. In V. I. Lenine. Obras Escolhidas. Tomo I. São Paulo. Editora Alfa-Ômega. 1986. pp. 578-671.

LESSA, Carlos (1988). A Estratégia de Desenvolvimento, 1974-1976. Sonho e Fracasso. Campinas. Instituto de Economia/UNICAMP (2a . Ed.). 1998. . O Rio de Todos os Brasis. Uma Reflexão em Busca de Auto-Estima. Rio de Janeiro. Editora Record. 2000. 
LEYSHON, Andrew e Nigel Trifth. "Spatial financial flows and the future global geography". In MABOGUN]E, Akin (ed.). The State of the Earth. Oxford. Blackwell Publishers. 1997. pp. 279-304.

LOJKINE, Jean. A Revolução Informacional. São Paulo. Editora Cortez. 1995.

LOPREATO, Francisco. O Colapso das Finanças Estaduais e a Crise da Federação. Campinas. Editora da Unicamp. 2002.

MACKINDER, Halford (1919). Democratic Ideals and Reality. New York. Henry Holt and Company. 1942.

MAKLER, Harry. "Bank transformation and privatization in Brazil. Financial federalism and some lessons about bank privatization". In The Quarterly Review of Economics and Finance No. 40. 2000. pp. 45-69.

MALIN, Mauro. "Agricultura de Reforma Agrária. In LAMOUNIER, Bolívar e Rubens Figueiredo (orgs.). A Era FHC. Um Balanço. São Paulo. Editora Cultura Associados. 2002. pp. 179-214.

MAMIGONIAN, Armen. "O Processo de industrialização em São Paulo". In Boletim Paulista de Geografia No. 50. 1976. pp. 83-101.

MANNERS, Gerald (1964). Geografia da Energia. Rio de Janeiro. Zahar Editores (2a. ed.). 1976.

MARQUES, Moacir. "A Estrutura da Rede Viária Terrestre de São Paulo". In Boletim Paulista de Geografia No. 55. São Paulo. AGB/SP. 1978. pp. 4773.

MARTIN, Jean-Marie. A Economia Mundial da Energia. São Paulo. Editora da Unesp. 1992.

MARTIN, Ron. "The New economic geography of money". In MARTIN, Ron (ed.). Money and the Space Economy. Sussex. John Wiley and Sons. 1999. pp. 3-27.

MARTINS, Luciano. Estado Capitalista e Burocracia no Brasil Pós-1964. Rio de Janeiro. Paz e Terra. 1985.

MASSEY, Doreen. "Introduction. Geography Matters". In MASSEY, Doreen and John Allen (eds.). Geography Matters! A Reader. London/New York. Cambridge University Press. 1984. pp. 1-11. 
MATELLART, Armand. Comunicação-Mundo. História das Idéias e das Estratégias. Petrópolis. Editora Vozes. 1994.

MATOS, Odilon. Café e Ferrovias. A Evolução Ferroviária de São Paulo e o Desenvolvimento da Cultura Cafeeira. São Paulo. Editora Alfa-Ômega. 1974.

MATTOS, Dirceu Lino de. "O Parque Industrial Paulistano". In AZEVEDO, Aroldo (org.). A Cidade de São Paulo. São Paulo: Aspectos da Metrópole Paulista (Vol III). São Paulo. Cia. Editora Nacional. 1958. pp. 5-98.

MAUSS, Marcel. Manuel d'Ethnographie. Paris. Payot. 1947.

MEGGINSON, William. "The Economics of bank privatization". Artigo publicado na Conference on Bank Privatization in Low and Middle Income Countries. Washington. The World Bank. 2003. 44p.

MEIRELLES, Antonio Chagas. "Competição Bancária". In Estudos APEC. s/d. pp. 101-104.

MELO, Paulo Roberto de Souza, Evaristo Carlos S. D. Rios e Regina M. V. Gutierrez. "Os Mercados de automação bancária e comercial". In BNDES Setoria/No. 11. 2000. pp. 47-70.

MERLIN, Pierre. Géographie, Économie et Planification des Transports. Paris. Presses Universitaires de France. 1991.

MICHALAK, Wielsaw e Richard Gibb. "Trading blocs and multilateralism in the world economy". In Annals of the Association of American Geographers Vol. 87. No. 2. 1997. pp. 264-279.

MICHALET, Charles-Albert. "Globalisation, attractivité et politique industrielle". In Cahiers dU GEMDEV no. 20. 1993. pp. 129-151.

MILLIET, Sérgio. Roteiro do Café e Outros Ensaios. Contribuição Para o Estudo da História Econômica e Social do Brasil (1941). São Paulo. Hucitec (4ª Ed.). 1982.

MINELLA, Ary. "Reforçando a hegemonia financeira privada: a privatização dos bancos estaduais". In: ALVIM, Valdir e Alceu Ferreira (orgs.). A Trama da Privatização. A Reestruturação Neoliberal do Estado. Florianópolis. Editora Insular. 2001. pp. 49-72. 
MONBEIG, Pierre (1952). Pioneiros e Fazendeiros de São Paulo. São Paulo. Editora Hucitec/Polis. 1984. . Novos Estudos de Geografia Humana Brasileira. São Paulo. Difusão

Européia do Livro. 1957. . "Les Capitaux et la Géographie", In Géographie Générale, Paris. Gallimard (Encyclopédie de La Pléiade). 1966. pp. 1515-1529.

MONIZ BANDEIRA, Luiz Alberto. Cartéis e Desnacionalização. A Experiência Brasileira: 1964-1974. São Paulo. Editora Civilização Brasileira. 1979.

MONTENEGRO, Marina Regitz. O Circuito Inferior da Economia Urbana na Cidade de São Paulo no Período da Globalização. São Paulo. Departamento de Geografia FFLCH/USP (Dissertação de Mestrado). 2006.

MORA, Mônica. "Federalismo e dívida estadual no Brasil". In IPEA/Textos Para Discussão No. 866. Março de 2002. 91 p.

MORAES, Antonio Carlos Robert. "Os Circuitos espaciais de produção e os círculos de cooperação no espaço". Departamento de Geografia FFLCH/USP (mimeo). 1985. . Ideologias Geográficas. Espaço, Cultura e Política no Brasil. São Paulo. Editora Hucitec. 1988.

MOURA, Alkimar. "Notas sobre o ajustamento do sistema bancário privado no Brasil pós-Real". In Revista Brasileira de Economia No. 52. 1998. pp. $27-$ 38.

MUMFORD, Lewis (1961). A Cidade na História. Suas Origens, Transformações e Perspectivas. São Paulo. Editora Martins Fontes. 1998.

MYRDAL, Gunnar (1956). Teoria Econômica e Regióes Subdesenvolvidas. Rio de Janeiro. Editora Saga. 1965.

NESS Jr., Walter. "Reducing government bank presence in the Brazilian financial system". In The Quarterly Review of Economics and Finance No. 40. 2000. pp. 71-84.

NOSSA CAIXA. Nossa História. 2002. 41 p. 
NÚMERO DE CARTÕES LIGADOS A LOJAS SUPERA O DE BANCOS. Folha de São Paulo. Caderno Dinheiro. 17/03/2003. pp. B1.

OATES, Wallace E. Federalismo Fiscal. Madrid. Instituto de Estudios de Administración Local. 1977.

OLIVEIRA, Fabrício Augusto de. A Reforma Tributária de 1966 e a Acumulação de Capital no Brasil. Belo Horizonte. Oficina de Livros. 1991.

OlIVEIRA, Fabrício Augusto de. Autoritarismo e Crise Fiscal no Brasil. São Paulo. Editora Hucitec. 1995.

OlIVEIRA, Francisco de (1977). Elegia Para uma Re(li)gião. Sudene, Nordeste, Planejamento e Conflito de Classes. Rio de Janeiro. Editora Paz e Terra (5a. ed.). 1987.

OlIVEIRA, Gilda Parga Lasssance de. "Estrutura do Sistema Financeiro Nacional". In CASTRO, Helio O. Portocarrero de (ed.). Introdução ao Mercado de Capitais. Rio de Janeiro. IBMEC. 1979. pp. 57-78.

ORTEGA Y GASSET (1939). Meditação Sobre a Técnica. Rio de Janeiro. Instituto Liberal. 1991.

PALATNIK, Beny e Luiz Orenstein. "Perspectivas do processo de privatização no Brasil". In Encontros com a Civilização Brasileira No. 15. 1979. pp. 4362.

PASSOS, Carlos de Faro. Estrutura Financeira e Desenvolvimento. O Caso do Brasil. São Paulo. Editora Atlas. 1973.

PASTORE, José. O Ensino Superior em São Paulo. Aspectos Quantitativos e Qualitativos de Sua Expansão. São Paulo. Cia. Editora Nacional/IPE-USP. 1971.

PERROUX, François. L'Économie des Jeunes Nations. Industrialisation e Groupement des Nations. Paris. PUF. 1962. . A Economia do Século XX. Lisboa. Livraria Morais Editora. 1967.

PETRELLA, Riccardo. "Some notes on growth poles". In KUKLINSKY, Anthony e Riccardo Petrella (eds.). Growth Poles and Regional Policies. Paris. Mouton. 1972. pp. 187-211. 
PINHEIRO, Armando Castelar. "A Experiência brasileira de privatização: o que vem a seguir?". IN BNDES Textos Para Discussão No. 87. 2000. 35p.

PINHEIRO, Armando e Fabio Giambiaggi. "As Empresas estatais e o programa de privatização do governo Collor". In Pesquisa e Planejamento Econômico Vol. 22, No. 2. 1992. pp. 241-288.

PINTO, Alvaro Vieira. Ideologia e Desenvolvimento Nacional. Rio de Janeiro. Instituto Superior de Estudos Brasileiros. 1960.

PINTO, Mariana Fernandes. O Processo de Automação Bancária Brasileiro. São Paulo. Deptartamento de Geografia FFLCH/USP (Trabalho de Graduação Individual). 2001.

PIRES, Hindemburgo. "Reestruturação inovativa e reorganização das instituições financeiras do setor privado no Brasil”. In Revista Geouerj No. 2. 1997. pp. 65-79.

PIRENNE, Henri (1933). História Econômica e Social da Idade Média. São Paulo. Editora Mestre Jou. 1966.

PUGA, Fernando. "Sistema Financeiro brasileiro: reestruturação recente, comparações internacionais e vulnerabilidade á crise cambial". In GIAMBIAGGl, Fabio e Maurício Mesquita Moreira (orgs.). A Economia Brasileira nos Anos 90. Rio de Janeiro. BNDES. 1999. pp. 411-465.

RAMALHO, Mario Lamas. Território e Macrossistema Elétrico Nacional: as Relações entre Privatização, Planejamento e Corporativismo. São Paulo. Departamento de Geografia FFLCH/USP (Dissertação de Mestrado). 2006.

RAMOS, Alberto Guerreiro (1958). A Redução Sociológica. Rio de Janeiro. Editora UFR]. 1996.

RAMOS, Soraia. "Sistemas técnicos agrícolas e meio técnico-científicoinformacional no Brasil". In SANTOS, Milton e María Laura Silveira. O Brasil. Território e Sociedade no Início do Século XXI. Rio de Janeiro. Record. 2001. pp. 375-387.

RANGEL, Ignácio (1963). A Inflação Brasileira. São Paulo. Editora Bienal (5ª. Ed.). 1986. 
RANGEL, Ignácio. Recursos Ociosos e Política Econômica. São Paulo. Editora Hucitec. 1980.

RATTNER, Henrique (coord.). Instituiçôes Financeiras e Desenvolvimento Tecnológico Autônomo: O Banco Nacional de Desenvolvimento Econômico e Social. São Paulo. IPE/USP, FIPE, FAPESP. 1991.

REED, Edward W. e Edward K. Gill. Bancos Comerciais e Múltiplos. São Paulo. Makron Books. 1994.

REYNAUD, Alain. Société, Espace et Justice. Paris. Presses Universitaires de France. 1981.

RICHTA, Radovan. Economia Socialista e Revolução Tecnológica. Rio de Janeiro. Editora Paz e Terra. 1972.

RIBEIRO, Ana Clara Torres. "Matéria e espírito. O poder (des)organizador dos meios de comunicação". In PIQUET, Rosélia e Ana Clara T. Ribeiro (orgs.). Brasil, Território da Desigualdade. Descaminhos da Modernização. Rio de Janeiro. Jorge Zahar Editor. 1991. pp. 44-55.

RIBEIRO, Paulo de Assis. Estrutura, Economia e Política dos Transportes. Rio de Janeiro. MEC/INL. 1956.

ROCHA, Sonia. “Pauvreté au Brésil. L'Épuisement des effets distributifs de la stabilisation monétaire". In Revue Tiers Monde No. 160. 1999. pp. 849870.

ROCHA, Sonia e Roberto Cavalcanti Albuquerque. "Geografia da pobreza extrema e vulnerabilidade à fome". In VELLOSO, João Paulo dos Reis e Roberto Cavalcanti Albuquerque (orgs.). A Nova Geografia da Fome e da Pobreza. Rio de Janeiro. José Olympio Editora. 2004. pp. 27-77.

ROSSINI, Rosa Ester. Geografia e Gênero. A Mulher na Lavoura Canavieira Paulista. São Paulo. Departamento de Geografia FFLCH/USP (Tese de Livre-Docência). 1988.

SAES, Flavio. As Ferrovias de São Paulo (1870-1940). São Paulo. Editora Hucitec/INL. 1981. . A Grande Empresa de Serviços Públicos na Economia Cafeeira (18501930]. São Paulo. Editora Hucitec. 1986a. 
SAES, Flavio. Crédito e Bancos no Desenvolvimento Econômico da Economia Paulista (1850-1930). São Paulo, IPE/USP. 1986b.

- "Crescimento e consolidação do sistema bancário em São Paulo na década de 1920". In DE LORENZO, Helena Carvalho e Wilma Peres da Costa (orgs.). A Década de 1920 e as Origens do Brasil Moderno. São Paulo. Editora Unesp. 1997. pp. 197-216.

SALAMA, Pierre. "Endettement et accentuation de la misère". In Revue Tiers Monde Tome XXV, no. 99. 1984. pp. 491-507.

SALVIANO Jr., Cleofas. Bancos Estaduais: Dos Problemas Crônicos ao Proes. Brasília. Banco Central do Brasil. 2004. 152p.

SANGUIN, André-Louis. La Géographie Politique. Paris. PUF. 1977.

SANTANA, José Vicente Mattos. Impacto do Novo Sistema de Pagamentos Brasileiro nos Custos dos Bancos. São Paulo. FEA/USP (Dissertação de Mestrado). 2005.

SANTOS, Milton. "Introdução". In TRICART, ]ean (et alli). Estudos de Geografia da Bahia. Geografia e Planejamento. Salvador. Publicações da Universidade da Bahia. 1958. pp. 5-8.

."Dimension temporelle et sistèmes spatiaux dans les pays du tiers monde". In Revue Tiers Monde Tome XIII, No. 50. 1972. pp. 247-268.

(1978). Por Uma Geografia Nova. Da Crítica da Geografia a uma Geografia Crítica. São Paulo. Editora Hucitec (3ª ed.). 1990. . Economia Espacial. Críticas e Alternativas. São Paulo. Hucitec. 1979a. . O Espaço Dividido. Os Dois Circuitos da Economia Urbana nos Países Subdesenvolvidos. Rio de Janeiro. Francisco Alves Editora. 1979b. . "Do Espaço sem nação ao espaço transnacionalizado". In RATTNER, Henrique (org.). Brasil 1990. Caminhos Alternativos do Desenvolvimento. São Paulo. Editora Brasiliense. 1979c. pp. 143-161. (1985). Espaço e Método. São Paulo. Editora Nobel (2a . ed.). 1988. . Metamorfoses do Espaço Habitado. São Paulo. Editora Hucitec. 1988. . O Espaço do Cidadão. São Paulo. Editora Nobel. 1988b. 
SANTOS, Milton (1992). "O Espaço: sistemas de objetos, sistemas de ações". In SANTOS, Milton. Técnica, Espaço, Tempo. Globalização e Meio TécnicoCientífico Informacional. São Paulo. Editora Hucitec. 1994. . A Urbanização Brasileira. São Paulo. Editora Hucitec. 1993. - Técnica, Espaço, Tempo. Globalização e Meio Técnico-CientíficoInformacional. São Paulo. Hucitec. 1994a.

. "O Retorno do território". In SANTOS, Milton (et alli). Território. Globalização e Fragmentação. São Paulo. Editora Hucitec/ANPUR. 1994b. pp. 15-20.

- Por Uma Economia Política da Cidade. O caso de São Paulo. São Paulo. Hucitec/EDUC. 1994C. . A Natureza do Espaço. Técnica e Tempo. Razão e Emoção. São Paulo. Editora Hucitec. 1996.

. "O Dinheiro e o território". In Geographia. Revista da Pós-Graduação em Geografia da UFF. Ano 1, No. 1. 1999. pp. 7-13. - Por Uma Outra Globalização. Do Pensamento Único à Consciência Universal. Rio de Janeiro. Record. 2000. . O País Distorcido. São Paulo. Publifolha. 2002.

SANTOS, Milton e Ana Clara Torres Ribeiro. "O Conceito de Região Concentrada". Universidade Federal do Rio de Janeiro/IPPUR. 1979.

SANTOS, Milton e María Laura Silveira. "Globalización y geografia: la compartimentación del espacio". In Geografía Aplicada y Desarrollo Ano XXI. No. 33. 1996. pp. 5-12.

SANTOS, Milton (et alli). "O Papel Ativo da Geografia. Um Manifesto". Universidade de São Paulo/LABOPLAN. 2000.

SANTOS, Roberto. "Relações de produção na Amazônia brasileira: perspectiva histórica, do século XVII ao século XX". In MENDES, Armando Dias (ed.). A Amazônia e seu Banco. Manaus. Editora Valer/BASA. 2002. pp. 213-241. 
SANTOS FILHO, Milton. "Sistema internacional de crédito. Conceitos e desenvolvimento". In SANTOS FILHO, Milton (org.). Instabilidade Econômica. Moeda e Finanças. São Paulo. Hucitec. 1993. pp. 41-60.

SARTRE, Jean-Paul. A Questão do Método. São Paulo. Difel. 1966.

SCHLESINGER, Hugo. Geografia Industrial do Brasil. São Paulo. Editora Atlas (2a . ed.). 1958.

SCHNEIDER, Ben Ross. "A Privatização no governo Collor: triunfo do liberalismo ou colapso do Estado desenvolvimentista?". In: Revista de Economia Política Vol. 12, No. 1. 1992. pp. 5-19.

SCHUTZ, John. A Crise Financeira da Abolição. (1879-1901). São Paulo. Edusp/Instituto Fernand Braudel. 1986.

SECCO, Lincoln. A Revolução dos Cravos e a Crise do Império Colonial Português. Economias, Espaços e Tomadas de Consciência. São Paulo. Alameda. 2004.

SILVA, Adroaldo Moura da. Intermediação Financeira no Brasil. Origens, Estrutura e Problemas. São Paulo. IPE/USP. 1981.

SILVA, Armando Corrêa da. "As Categorias como fundamentos do conhecimento geográfico". In SANTOS, Milton (et alli). O Espaço Interdisciplinar. São Paulo. Editora Nobel. 1986. pp. 25-37.

SILVA, Carlos Alberto F. da. "As Transformações da rede de gestão territorial do Banco Nacional S/A sob a égide da revolução telemática". In Território No. 6. Laget/UFRJ. 1999. pp. 55-71.

SILVA, Carlos Henrique C. da. "As grandes empresas varejistas e suas estratégias locacionais na grande São Paulo". In Geografia Vol. 28. no. 3. (Rio Claro). 2003. pp. 379-395.

SILVA, Jackeline. Sistemas de Redes de Transações Bancárias. Uma Análise sob as Óticas Tecnológica e Jurídica. São Paulo. Escola Politécnica/USP (Dissertação de Mestrado). 2005.

SILVA Jr., Gilberto Oliveira. "BNDES: Promovendo um ordenamento territorial desigual". In Anais do XVIo. Encontro Nacional de Geógrafos. AGB/Rio Branco. 2006. 14p. 
SILVEIRA, María Laura. "Os Novos conteúdos da regionalização: lugares modernizados e lugares letárgicos no planalto nordpatagônico". In Finisterra Vol. XXIX, no. 58. 1994. pp. 267-284.

- “Modernización agrícola, productividad espacial y guerra de mercados, el ejemplo de la Patagônia norte Argentina". In Geografía y Desarrollo No. 13. 1996. pp. 89-95.

. Um País, Uma Região. Fim de Século e Modernidades na Argentina. São Paulo. Fapesp/Laboplan. 1999.

- "O Espaço da globalização: usos diversos, comando único". In SOUZA, Álvaro (et alli). Milton Santos. Cidadania e Globalização. Bauru. Editora Saraiva/AGB-Bauru. 2000a.

. "L'Espace de la globalisation: usage divers, commandement unique". In CERUR. Notes de Recherche No. 15. Paris. 2000b. 8p.

- "Por Um Conteúdo da Reflexão Epistemológica em Geografia”. In SOUZA, Álvaro (et alli). Paisagem, Território e Região. Em Busca da Identidade. Cascavel. Editora Edunioeste. 2000c. pp. 21-28.

. "Uma globalização desnecessária, um território instável". In Ciência Geográfica Vol. 1, No. 21. 2002. pp. 43-46.

- Argentina: Território e Globalização. São Paulo. Editora Brasiliense. 2003a.

. "A Região e a invenção da viabilidade do território". In SOUZA, Maria Adélia (ed.). Território: Usos e Abusos. Campinas. Edições Territoriais. 2003b. pp. 408-416.

- "Globalización y circuitos de la economía urbana en ciudades brasileñas". In Cuadernos del Cendes Ano 21. No. 57. 2004. pp. 1-21. . "Por que há tantas desigualdades sociais no Brasil? Um Panorama da riqueza e da pobreza brasileira". In ALBUQUERQUE, Edu (org.). Que País é Esse? São Paulo. Editora Globo. 2005. pp. 141-178.

SIMMEL, Georg (1902). "A Metrópole e a vida mental". In VELHO, Otavio Guilherme (org.). O Fenômeno Urbano. Rio de Janeiro. Zahar Editores (3a. ed.) 1976. pp. 11-25. 
SIMONDON, Gilbert (1958). Du Mode d'Existence des Objets Techniques. Paris. Aubier. 1989

SINGER, Paul. Para Entender o Mundo Financeiro. São Paulo. Contexto. 2000.

SOUZA, Maria Adélia de. Governo Urbano. São Paulo. Editora Nobel. 1988. . A Identidade da Metrópole. A Verticalização em São Paulo. São Paulo. Editora Hucitec/Edusp. 1994.

STOURDZÉ, Yves. “Espace, Circulation, Pouvoir”. In Les Temps Modernes. 1973.

SUZIGAN, Wilson. "As Empresas do governo e o papel do Estado na economia". In REZENDE, Fernado e outros. Aspectos da Participação do Governo na Economia. Rio de Janeiro. IPEA/INPES. 1976. pp. 77-134.

SUZIGAN, Wilson e Annibal V. Villela. Política de Governo e Crescimento da Economia Brasileira (1889-1945). Rio de Janeiro. IPEA/INPES. 1973.

SWIFT. Swift Anual Report 2005. Raising Ambitions. 2006 (extraído de http://www.swift.com/index.cfm?item_id=58373 em 09/10/2006).

TAVARES, Maria da Conceição (1972). Da Substituição de Importações ao Capitalismo Financeiro. Rio de Janeiro. Zahar Editores (7ª ed). 1978.

TAVARES, Maria da Conceição e José Luís Fiori. Desajuste Global e Modernização Conservadora. Rio de Janeiro. Editora Paz e Terra. 1996.

TAVARES, Martus e Nelson Carvalheiro. O Setor Bancário Brasileiro: Alguns Aspectos do Crescimento e da Concentração. São Paulo. FIPE/USP (Série Estudos Econômicos Vol. 51). 1985.

TEIXEIRA, Natermes Guimarães. Origens do Sistema Multibancário Brasileiro. Das Reformas dos Anos 60 à Crise dos Anos 80. Campinas. Instituto de Economia/UNICAMP. 2000.

THOM, René. "Le Problème des ontologies régionales en science". In THOM, René. Apologie du Logos. Paris. Hachette. 1990. pp. 455-467.

TOLEDO Jr., Rubens de. Território e Densidades Técnicas: Redes de Fibra Óptica no Brasil. São Paulo. Departamento de Geografia FFLCH/USP (Tese de Doutorado). 2002.

TOMELIN, Mario. O Quaternário. Seu Espaço e Poder. Braśília. Ed. UnB. 1988. 
TRAVASSOS, Mario. Introdução à Geografia das Comunicações Brasileiras. Rio de Janeiro. Livraria José Olympio Editora. 1942.

TRINER, Gail. "The Formation of modern Brazilian banking, 1906-1930: opportunities and constraints presented by the public and private sectors". In Journal of Latin American Studies, No. 28. Cambridge University Press. 1996. pp. 49-74.

TROSTER, Roberto Luis. "Concentração Bancária". 2004 texto disponível em http://www.febraban.org.br/Arquivo/Servicos/Imprensa/Conc0404.pdf.

ULMMAN, Edward. Geography as Spatial Interaction. Seattle and London. University of Washington Press. 1980.

VASCONCELLOS, Gilberto Felisberto. O Príncipe da Moeda. Rio de Janeiro. Editora Espaço e Tempo. 1997.

VASCONCELOS, Marcos R., Eduardo Strachman e José Ricardo Fucidji. "Liberalização e desregulamentação bancária: motivações, conseqüências e adaptações". In Nova Economia Vol 13. No. 1. 2003. pp. 101-140.

VEBLEN, Thorstein (1889). A Teoria da Classe Ociosa. Um Estudo Econômico das Instituiçóes. São Paulo. Abril Cultural. 1983.

VELLOSO, João Paulo dos Reis. "Introdução". In VELLOSO, João Paulo dos Reis e Roberto Cavalcanti Albuquerque (orgs.). A Nova Geografia da Fome e da Pobreza. Rio de Janeiro. José Olympio Editora. 2004. pp. 9-16.

VERGOLINO, José Raimundo e Gustavo Maia Gomes. "Metamorfoses da economia amazônica". In MENDES, Armando Dias (ed.). A Amazônia e seu Banco. Manaus. Editora Valer/BASA. 2002. pp.245-277.

VIDEIRA, Sandra Lúcia. "Bancos estrangeiros no Brasil: um agente urbano". In Scripta Nova. Revista Electrónica de Geografía y Ciencias Sociales. Barcelona Vol. IX. No. 194. 2005. 10 p.

VIDOTTO, Carlos Augusto. "Reforma dos bancos federais brasileiros: programa, base doutrinária e afinidades teóricas". In Economia e Sociedade Vol. 14. No. 1. 2005. pp.57-84.

VILHENA, Fernanda e João Sicsú. "Mapeamento da produtividade do trabalho nos bancos brasileiros". In Ensaios FEE Vol. 25, No. 1. 2004. pp. 15-144. 
WARF, Barney. "Telecommunications and the globalization of financial services". In The Professional Geographer Vol. 41, No. 3. 1987. pp. 257-271.

. "The hipermobility of capital and the collapse of the Keynesian state". In MARTIN, Ron (ed.). Money and the Space Economy. Sussex. John Wiley and Sons. 1999. pp. 227-239.

. "International competition between satellite and fiber optic carriers: a

geographical perspective". In The Professional Geographer Vol. 58, No. 1. 2006. pp. 1-11.

WEBER, Max (1904). A Ética Protestante e o Espírito do Capitalismo. São Paulo. Editora Pioneira (13a. ed.). 1999.

WERLANG, Sergio Ribeiro e Arminio Fraga Neto, "Os Bancos estaduais e o descontrole fiscal: alguns aspectos". In Revista Brasileira de Economia Vol. 49(2), abril/junho 1995. pp. 265-275.

WERLEN, Benno (1988). Society, Action and Space. An Alternative Human Geography. London and New York. Routledge. 1993. . Zur Ontologie Von Gesselchaft und Raum. Stuttgart. Franz Steiner Verlag. 1999.

. "Regionalismo e sociedade política". In Geographia. Revista da PósGraduação em Geografia da UFF. Ano II, No. 4. 2000. pp. 7-25. . "Geographie culturelle et tournant culturelle". In Geographie et Cultures No. 47. 2003. 7-27.

WERNECK, Rogério. "Federalismo fiscal e política de estabilização no Brasil". In Revista Brasileira de Economia Vol 49(2), abril/junho 1995. pp. 375390.

XAVIER, Marcos. "Os Sistemas de engenharia e a tecnicização do território. O exemplo da rede rodoviária brasileira". In SANTOS, Milton e María Laura Silveira. O Brasil. Território e Sociedade no Início do Século XXI. Rio de Janeiro. Record. 2001. pp. 329-343. 